UNIVERSIDADE DE SÃO PAULO

FACULDADE DE ECONOMIA, ADMINISTRAÇÃO E CONTABILIDADE DE RIBEIRÃO PRETO

DEPARTAMENTO DE ECONOMIA

JULIANA SOUZA SCRIPTORE

A parceria público-privada no saneamento básico brasileiro: uma proposta para o desenvolvimento do setor

Orientador: Prof. Dr. Rudinei Toneto Junior 
Prof. Dr. João Grandino Rodas

Reitor da Universidade de São Paulo

Prof. Dr. Rudinei Toneto Junior Diretor da Faculdade de Economia, Administração e Contabilidade de Ribeirão Preto

Prof. Dr. Walter Belluzzo Junior Chefe do Departamento de Economia 


\section{A parceria público-privada no saneamento básico brasileiro: uma proposta para o desenvolvimento do setor}

Dissertação apresentada ao Programa de PósGraduação em Economia da Faculdade de Economia, Administração e Contabilidade de Ribeirão Preto da Universidade de São Paulo como requisito para obtenção do título de Mestre em Economia.

Orientador: Prof. Dr. Rudinei Toneto Junior. 
AUTORIZO A REPRODUÇÃO E DIVULGAÇÃO TOTAL OU PARCIAL DESTE TRABALHO, POR QUALQUER MEIO CONVENCIONAL OU ELETRÔNICO, PARA FINS DE ESTUDO E PESQUISA, DESDE QUE CITADA A FONTE.

FICHA CATALOGRÁFICA

Scriptore, Juliana Souza

A parceria público-privada no saneamento básico brasileiro: uma proposta para o desenvolvimento do setor. Ribeirão Preto, 2010.

153 p. : il. ; $30 \mathrm{~cm}$

Dissertação de mestrado, apresentada à Faculdade de Economia, Administração e Contabilidade de Ribeirão Preto da Universidade de São Paulo.

Orientador: Toneto Junior, Rudinei.

1. Saneamento Básico. 2. Regulação. 3. Parceria Público-Privada. 


\section{FOLHA DE APROVAÇÃO}

\section{Juliana Souza Scriptore}

A parceria público-privada no saneamento básico brasileiro: uma proposta para o desenvolvimento do setor

Dissertação apresentada ao Programa de PósGraduação em Economia da Faculdade de Economia, Administração e Contabilidade de Ribeirão Preto da Universidade de São Paulo como requisito para obtenção do título de Mestre em Economia.

Aprovada em:

BANCA EXAMINADORA

Prof. Dr.

Instituição: Assinatura

Prof. Dr.

Instituição: Assinatura

Prof. Dr.

Instituição: Assinatura 
Dedico esse trabalho a minha avó Rosa (in memorian) em agradecimento a tudo que realizou por mim, pela grande importância que teve em minha vida e pelo seu exemplo de superação. 


\section{AGRADECIMENTOS}

Em primeiro lugar, agradeço a Deus, por nunca ter me abandonado em todos os momentos difíceis do mestrado seja me dando força ou inspiração para superar os obstáculos.

Depois aos meus pais Genaro e Célia por serem meu porto seguro, pela luta (cada um a sua maneira) em me mostrar a importância do estudo, pela torcida e por serem os que realmente seguram a barra nos piores momentos. Obrigada por tudo, amo tanto vocês! A minha irmã Gabriela, pelo amor incondicional, pelos conselhos, pela preocupação e por me dar a certeza que sempre estaremos juntas, independente de qualquer circunstância da vida.

À minha querida tia Carmen, por ter sido mais que tia e contribuído sob diferentes formas para a realização desse objetivo. Obrigada pelas conversas, pelo consolo e por ser sempre amorosa. Ao meu cunhado Alan, ao meu tio e padrinho Antonio Carlos e a minha tia Sandra: sempre presentes em todos os momentos, com palavra encorajadora e dedicação.

Ao meu orientador Rudinei Toneto pelo exemplo de profissional respeitado que é, entre todos, pela amizade, paciência e apoio nos momentos conturbados. Além disso, o agradeço por ter me apresentado e incentivado a estudar um setor tão importante para o futuro do país: sinto-me realizada, como economista, pela intenção de contribuir, mesmo que minimamente, para o objetivo de vencer os obstáculos que impedem a população brasileira do acesso aos serviços adequados de saneamento básico, direito humano fundamental para se ter uma vida digna.

Aos professores Sérgio Sakurai, Alexandre Nicolella e Jaylson Silveira, pela ajuda, disposição, conselhos e comprometimento que sempre demonstraram.

Aos amigos Iraci João, Leandro Máximo, Camila Coelho, Paula Regina e Franciane Cardoso por dividir aflições e dúvidas, mas também pelos momentos de descontração. Ao grande amigo Diogo Prince pela ajuda em superar as barras do mestrado, das disciplinas e até nos momentos pessoais críticos. Agradeço também às meninas da sala Priscila Trigo, Maíra Scarpeli e Liliane Morandi, ao pessoal da sala da pós e a Beatriz Selan que também fazem parte dessa importante realização da minha vida. Por fim, agradeço ao apoio da Fundação de Amparo à Pesquisa do Estado de São Paulo, pela concessão da bolsa de mestrado e pelo apoio financeiro para realização desta pesquisa, e à Universidade de São Paulo pela infra-estrutura oferecida. 


\section{RESUMO}

SCRIPTORE, J. S. A parceria público-privada no saneamento básico brasileiro: uma proposta para o desenvolvimento do setor. 2010. 153f. Dissertação (Mestrado) - Faculdade de Economia, Administração e Contabilidade de Ribeirão Preto, Universidade de São Paulo, Ribeirão Preto, 2010.

Atualmente, no Brasil, a atenção ao setor de saneamento básico tornou-se uma questão de saúde pública e ambiental. A evolução dos indicadores recentes mostra que o nível de cobertura se encontra em patamares aquém do necessário frente a uma elevada demanda, decorrente do crescimento populacional e de um histórico insuficiente de atendimento no país. Esse setor enfrenta dificuldades na captação de recursos para investimentos por parte das empresas públicas, pois estas se encontram submetidas a regras fiscais tais como limites de endividamento, contingenciamento de crédito e metas de superávit. Além disso, registram uma baixa geração de excedentes, ineficiência operacional e ingerência política. $O$ avanço da iniciativa privada ocorreu de forma tímida no setor, decorrente do caráter fortemente social do mesmo e da ausência de diretrizes que definam suas políticas. Com a introdução de novo marco regulatório estabelecido por meio da Lei $n^{0} 11.445 / 2007$, surge um ambiente institucional com menos incerteza para atuação de investimentos privados.

Diante das preocupações com processos de privatização, como, por exemplo, trade-off custo/qualidade com o qual a empresa privada pode se deparar, constatou-se, por meio de estimação de dados em cross section, via Mínimos Quadrados Ordinários, os tipos de prestadores que tiveram melhor desempenho nos indicadores que compõe as funções-objetivo de cada empresa enunciadas pela literatura do setor.

Os resultados indicaram que a participação da iniciativa privada foi positiva para o setor na medida em que apresentou menores perdas de distribuição e de faturamento, maiores índices de produtividade, investimento e qualidade dos serviços. Portanto, pode-se sugerir que as parcerias entre setor público e privado são alternativas viáveis para acelerar o cumprimento das metas de universalização dos serviços.

Palavras-Chave: Saneamento básico. Parceria público-privada. Marco regulatório. Privatização. Metas de universalização. Eficiência Operacional. 


\begin{abstract}
SCRIPTORE, J. S. The public-private partnership in the Brazilian basic sanitation: a proposal for the development of the sector. 2010. 153f. Dissertation (Master) - Faculdade de Economia, Administração e Contabilidade de Ribeirão Preto, Universidade de São Paulo, Ribeirão Preto, 2010

Currently, in Brazil, the attention to basic sanitation sector has become a matter of public health and environmental concerns. The evolution of the recent researches states that the level of coverage is not enough to fulfill the high demand due to population growth and a history of inadequate investments in the country. This sector is facing difficulties in raising funds by public enterprises, as these are subject to tax rules such as limits on debt, curtailment of credit and surplus targets. In addition, they have had low generation of profit, operational inefficiency and political interference. The private enterprise investments in the sector have not being significant due to its evident social character and the lack of guidelines that define their policies. With the introduction of new regulatory framework established by the Law number 11.445/2007, an institutional environment have being created with less uncertainty for the private investments.

In face of the concerns about the privatization processes, for instance the cost-quality trade-off which a private company may have to deal with, it was found through cross section data estimation via OLS (Ordinary Least Squares) the supplier types that had better performance on the indicators that comprise the objective functions of each company listed in the literature of the sector.

The results indicated that the participation of the private capital was positive for the sector as it showed lower losses on sales and distribution, higher rates of productivity, investment and quality of services. Therefore, it can be suggested that partnerships between public and private sectors are viable alternatives to accelerate the achievement of the targets of a universalized service.
\end{abstract}

Keywords: Basic sanitation. Public-private partnership. Regulatory framework. Privatization. Universalized targets. Operational Efficiency. 


\section{LISTA DE GRÁFICOS}

\section{Capítulo 2}

Gráfico 2.1 - Contratos de Parceria Público-privada.

\section{Capítulo 4}

Gráfico 4.1 - Média por tipo de prestador dos indicadores operacionais de água..... 103

Gráfico 4.2 - Média por tipo de prestador dos indicadores operacionais de esgoto. 108

Gráfico 4.3 - Média por tipo de prestador dos indicadores econômicos, financeiros e administrativos

Gráfico 4.4 - Média por tipo de prestador dos indicadores de investimento I 118

Gráfico 4.5 - Média por tipo de prestador dos indicadores de investimento II 118

Gráfico 4.6 - Média por tipo de prestador dos indicadores de qualidade 122 


\section{LISTA DE QUADROS}

\section{Capítulo 2}

Quadro 2.1 - Características do setor de saneamento e suas repercussões 48

\section{Capítulo 3}

Quadro 3.1 - As funções objetivo e sinais esperados dos coeficientes. 88 


\section{LISTA DE TABELAS}

\section{Capítulo 1}

Tabela 1.1 - Formação Bruta de Capital Fixo em setores de infra-estrutura (em \% do PIB)................ 33

Tabela 1.2 - Evolução da cobertura dos serviços de água e esgoto no Brasil (\%)................................ 34

Tabela 1.3 - Percentual de moradores em domicílios particulares permanentes com abastecimento de água, por tipo de abastecimento e situação do domicílio - Grandes Regiões, 1992 e 2007............. 39 Tabela 1.4 - Percentual de moradores em domicílios particulares permanentes por tipo de esgotamento sanitário e situação do domicílio - Grandes Regiões, 1992 e 2007.

\section{Capítulo 2}

Tabela 2.1 - Resumo dos dispositivos do novo marco regulatório ........................................................ 50

Tabela 2.2 - Quantidade dos tipos de prestadores por região................................................................ 57

Tabela 2.3 - Agrupamento dos prestadores segundo abrangência regional e natureza jurídica ............ 59

Tabela 2.4 - Número de mudanças entre categorias de natureza jurídica por ano e região ................... 60

Tabela 2.5 - Número de saídas e entradas em cada categoria de natureza jurídica .............................. 60

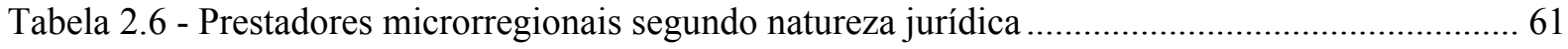

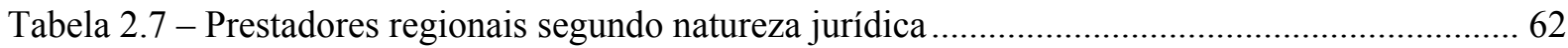

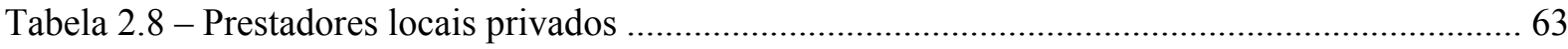

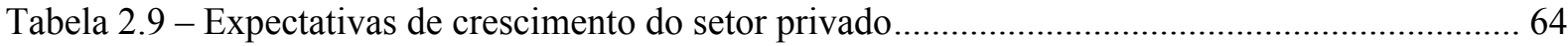

Tabela 2.9.1 - Tipo de serviço prestado por categoria de abrangência ................................................... 64

Tabela 2.9.2 - Quantidade de municípios atendidos por cada tipo de prestador .................................... 65

\section{Capítulo 3}

Tabela 3.1 - Índice de atendimento total de água e esgoto por região geográfica................................. 72

Tabela 3.2 - Índice de atendimento total de água e esgoto por população municipal ........................... 73

Tabela 3.3 - Índice de atendimento total de água e esgoto por taxa de urbanização .............................. 74

Tabela 3.4 - Índice de atendimento total de água e esgoto por renda per capita.................................... 75

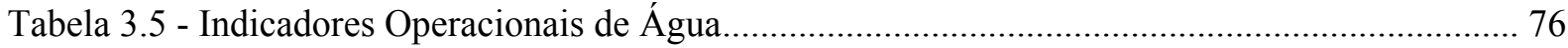

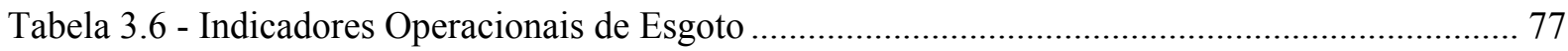

Tabela 3.7 - Indicadores Econômicos, Financeiros e Administrativos ………………………............... 79

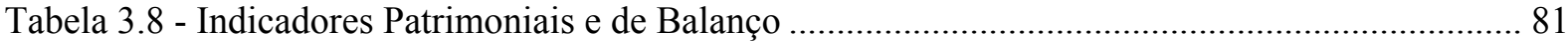

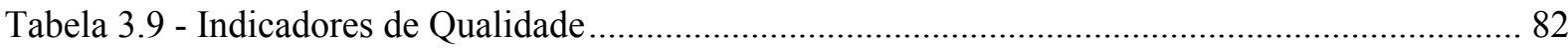

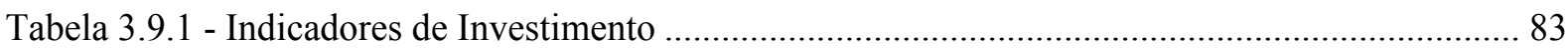

Tabela 3.9.2 - Estimativa para cumprimento das Metas do Objetivo de Desenvolvimento do Milênio 


\section{Capítulo 4}

Tabela 4.1 - Estatísticas Descritivas das Variáveis Explicativas do Modelo Econométrico 101

Tabela 4.2 - Estatísticas Descritivas das Variáveis Dependentes do Modelo Econométrico 101

Tabela 4.3 - Teste de média indicadores operacionais de água 103

Tabela 4.4 - Estimação I indicadores operacionais de água 104

Tabela 4.5 - Estimação II indicadores operacionais de água............................................................. 106

Tabela 4.6 - Relações entre os tipos de prestadores de serviços de saneamento .................................. 108

Tabela 4.7 - Teste de média indicadores operacionais de esgoto...................................................... 109

Tabela 4.8 - Estimação indicadores operacionais de esgoto............................................................... 110

Tabela 4.9 - Relações entre os tipos de prestadores de serviços de saneamento ................................. 112

Tabela 4.9.1 - Teste de média indicadores econômicos, financeiros e administrativos ....................... 113

Tabela 4.9.2 - Estimação I indicadores econômicos, administrativos e financeiros............................ 114

Tabela 4.9.3 - Estimação II indicadores econômicos, administrativos e financeiros .......................... 116

Tabela 4.9.4 - Relações entre os tipos de prestadores de serviços de saneamento .............................. 117

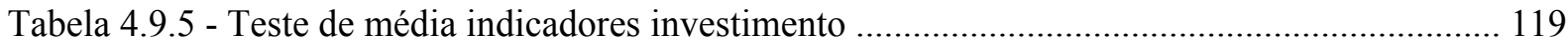

Tabela 4.9.6 - Estimação indicadores investimentos ....................................................................... 120

Tabela 4.9.7 - Relações entre os tipos de prestadores de serviços de saneamento .............................. 122

Tabela 4.9 .8 - Teste de média indicador qualidade .......................................................................... 123

Tabela 4.9.9 - Estimação indicador de qualidade ............................................................................. 123

Tabela 4.9.9.1 - Relações entre os tipos de prestadores de serviços de saneamento ........................... 124 


\section{LISTA DE SIGLAS}

ABCON Associação Brasileira das Concessionárias Privadas dos Serviços Públicos de Água e Esgoto

Abdib Associação Brasileira de Infra-Estrutura e Indústria de Base

BID Banco Interamericano de Desenvolvimento

BIRD Banco Internacional para Reconstrução e Desenvolvimento

BNDES Banco Nacional de Desenvolvimento Econômico e Social

BNH Banco Nacional de Habitação

CEF Caixa Econômica Federal

CESB Companhia Estadual de Saneamento

CF Constituição Federal

CSN Companhia Siderúrgica Nacional

CVRD Companhia Vale do Rio Doce

DNOCS Departamento Nacional de Obras contra as Secas

DNOS Departamento Nacional de Obras de Saneamento

FAE Fundo Estadual de água e esgoto

FGTS Fundo de Garantia de Tempo de Serviço

FSESP Fundação Serviço Especial de Saúde Pública

FUNASA Fundação Nacional da Saúde

LRF Lei de Responsabilidade Fiscal

MC Ministério das Cidades

MPO Ministério do Planejamento e Orçamento

MQO Mínimos Quadrados Ordinários

ODM Objetivos do Desenvolvimento do Milênio

PAC Programa de Aceleração do Crescimento 
PAEG Programa de Ação Econômica do Governo

PLANASA Plano Nacional de Saneamento

PMSS Programa de Modernização do Setor de Saneamento

PNAD Pesquisa Nacional de Amostras e Domicílios

ReCESA Rede Nacional de Capacitação e Extensão Tecnológica em Saneamento Ambiental

SAAE Serviços Autônomos de Água e Esgoto

Sepurb Secretaria de Política Urbana

SFS Sistema Financeiro de Saneamento

SNIS Sistema Nacional de Informações sobre Saneamento

SNISA Sistema Nacional de Informações em Saneamento Básico

SNSA Secretaria Nacional de Saneamento Ambiental

STF Supremo Tribunal Federal 


\section{SUMÁRIO}

INTRODUÇÃO ..........................................................................................................15

Capítulo 1. A INDÚSTRIA DE SANEAMENTO BÁSICO ......................................21

1.1) Importância do setor de saneamento básico. ..........................................................21

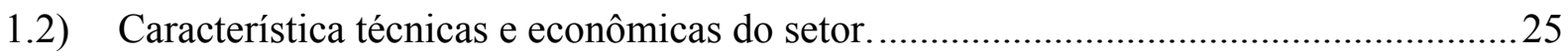

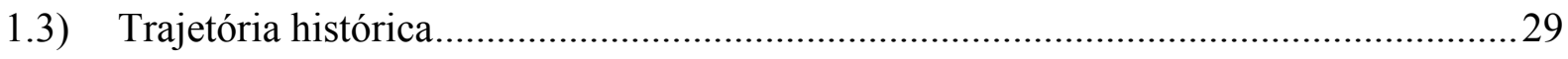

Capítulo 2. NOVO MARCO REGULATÓRIO E PARCERIA PÚBLICO-PRIVADA. ....43

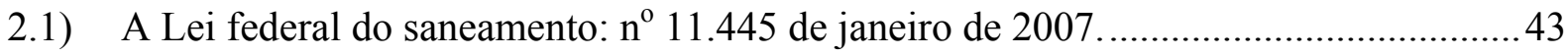

2.2) A questão da titularidade e as diversas formas de regulação. ...................................... 45

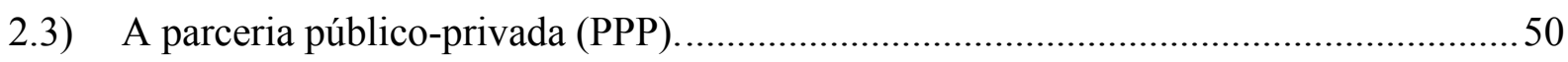

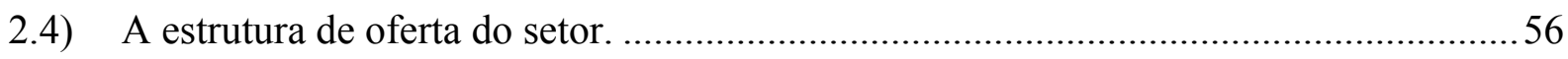

Capítulo 3. MENSURAÇÃO DE EFICIÊNCIA E ANÁLISE DESCRITIVA..............66

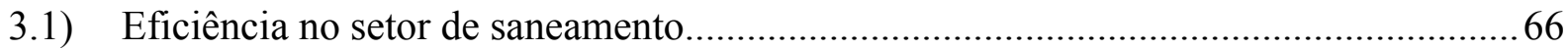

3.2) Caracterização da cobertura dos serviços sanitários $(2002 / 2007)$................................ 70

3.3) Desempenho médio por tipo de prestador (2002/2007).......................................... 75

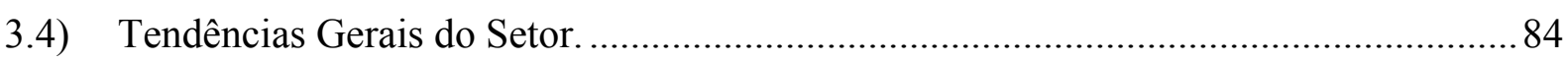

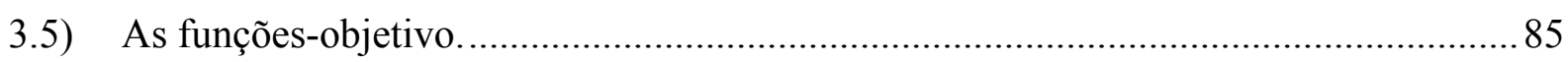

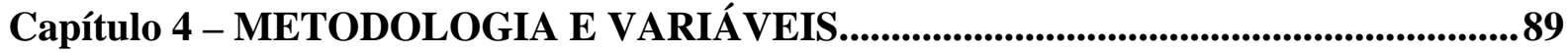

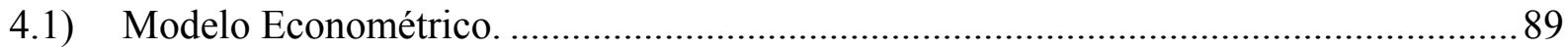

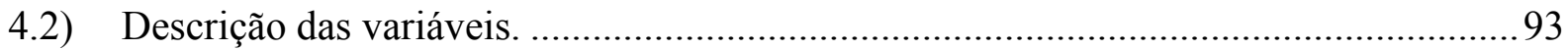

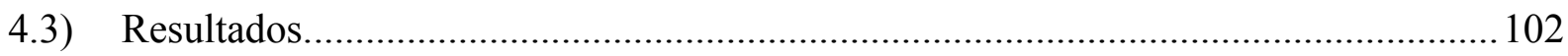

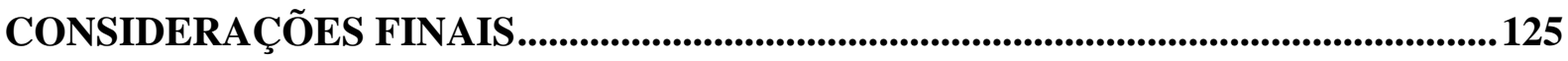

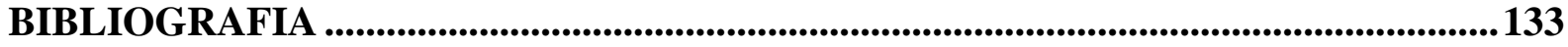

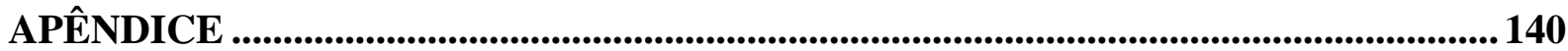




\section{INTRODUÇÃO}

A importância do setor de saneamento básico vai além dos impactos positivos gerados enquanto setor de infra-estrutura: suas características peculiares fazem com que o investimento no mesmo se traduza em elemento estratégico para o desenvolvimento econômico de longo prazo do país. Além de prover o acesso a um direito humano elementar de todos que é a água segura, o setor apresenta inúmeras externalidades que impactam a saúde pública, o meio ambiente, a qualidade de vida da população e o alcance do desenvolvimento sustentável nacional.

A principal justificativa para a necessidade de se fornecer um sistema de saneamento básico adequado é o impacto direto na saúde da população e, principalmente, na taxa de mortalidade infantil. As doenças de veiculação hídrica, originadas pela falta de abastecimento de água e mínimas condições de esgotamento sanitário, impactam diretamente os organismos mais suscetíveis a elas, que são as crianças.

Registra-se ainda o impacto ambiental, em que a mais grave conseqüência é a contaminação irreversível dos lençóis freáticos pelo lançamento de esgoto in natura em solos e rios, o impacto sobre o capital humano (provoca queda da produtividade do trabalhador) o impacto na geração de renda interna do país, a disseminação de focos que alastram e perpetuam a pobreza; entre outros.

A demanda crescente por serviços de saneamento básico aumentou juntamente com as taxas de urbanização e crescimento populacional registrados nas últimas décadas. Entretanto, o aumento dos investimentos em novos sistemas e na manutenção dos já existentes não acompanhou a demanda no mesmo ritmo. A história da oferta de tais serviços, no Brasil, é marcada por contínuas tentativas de ampliar o serviço, muitos avanços e alguns recuos.

O principal caso de sucesso no setor foi representado pelo Plano Nacional de Saneamento, Planasa, instituído em 1971 pelo governo federal, que conseguiu aumentar

significativamente os índices de atendimento de água e, em menor escala, de coleta e tratamento de esgoto. Esse sistema conferiu os traços do arranjo institucional do setor nos dias atuais: criou as chamadas Companhias Estaduais de Saneamento, às quais os municípios poderiam delegar a concessão da execução de obras e operação dos sistemas de saneamento.

A despeito do grande avanço verificado com o Planasa, a conjuntura econômica do início dos anos 80 e outros fatores relacionados a dificuldades internas de execução do Plano, 
levaram à sua extinção em 1992. Desde então, verificou-se um vazio institucional no setor. Na década atual, muitas incertezas regulatórias estiveram presentes na definição de políticas de saneamento, entretanto, em janeiro de 2007, o governo promulgou a lei federal $\mathrm{n}^{\mathrm{o}} 11.445$ do Saneamento: o esperado marco regulatório do setor.

Porém, mesmo com todos esses esforços e avanços, a insuficiência do setor é histórica na realidade brasileira, ou seja, os indicadores relativos aos serviços de água e esgoto ainda estão aquém do necessário para se alcançar as metas de universalização.

Dados recentes da última Pesquisa Nacional de Amostras e Domicílios (Pnad) indicam que o Brasil conseguiu alcançar em 2007, a meta do milênio relativamente ao acesso à água potável nas áreas urbanas, prevista para 2015, uma vez que existe água canalizada de rede geral no interior do domicílio de $91,3 \%$ dos moradores de diversas cidades do país. Por outro lado, somente pouco mais da metade da população urbana $(57,4 \%)$ possui coleta de esgoto. Além disso, apenas um terço do material coletado recebe tratamento e disposição final dos dejetos adequada.

Logo, o déficit de acesso relacionado aos índices de atendimento de esgoto é o ponto mais preocupante no objetivo do alcance da universalização. Contudo, apesar dos índices de abastecimento de água serem mais satisfatórios, isso não significa que a maior parte da população conta com serviços de água tratada e encanada adequados: as condições de atendimento no país são bastante heterogêneas entre as regiões geográficas, os vários níveis de renda per capita municipal e as diferentes taxas de urbanização.

Nesse sentido, de acordo com as informações de 2007 do banco de dados exclusivo do setor, o Sistema Nacional de Informações sobre Saneamento (SNIS), em relação aos índices de atendimento de água, as regiões Norte e Nordeste apresentam médias inferiores à média nacional e para esgoto são quatro as regiões que apresentam índice abaixo da média do país: Sul, Centro-Oeste, Nordeste e Norte. Os municípios que apresentam maiores taxas de urbanização tendem a apresentar melhores índices de cobertura e, em relação ao nível de renda per capita, quanto maior esse nível em cada município mais elevado será o índice de atendimento a serviços sanitários.

Portanto, municípios localizados fora do eixo de maior ativismo econômico (Sudeste, Sul e, em parte, Centro-Oeste), aqueles de menor renda per capita e/ou os municípios que possuem parte considerável de sua população em áreas rurais, possivelmente apresentem menores índices de atendimento de tais serviços: realidade não revelada quando se considera apenas a média nacional como parâmetro de análise do setor. 
$\mathrm{Na}$ maior parte dos países, e também no Brasil, os serviços de saneamento são fornecidos pelo governo e/ou com sua regulação. Além das externalidades que o setor gera, apresenta algumas características peculiares que justificam essa forma de provisão: são serviços de caráter essencial à população, constituem-se bens públicos e organizam-se sob a estrutura de mercado denominada monopólio natural, ou seja, exibem economias de escala, custo médio por unidade produzida decrescente, para um determinado ramo de produção, o que faz com que a atuação de uma única empresa seja mais vantajosa do que se houvessem mais de uma delas no mercado.

Além disso, a estrutura de oferta do setor tem grandes influências herdadas da época do Planasa: grande parte da população urbana brasileira (aproximadamente 70\%) é atendida por empresas estaduais públicas de saneamento, ou seja, as antigas CESBs. A maioria dessas empresas enfrenta dificuldades em tomar empréstimos, pois estão submetidas a restrições fiscais que limitam seu endividamento e, conseqüentemente, os níveis de investimento no setor. Além disso, apresentam gestão ineficiente e fluxo de caixa deficitário, o que as impossibilitam de fazer investimentos por meio de recursos próprios.

O baixo nível de investimentos, efetivamente realizados, verificado nos últimos anos está em descompasso com o montante de investimento necessário para que seja atingida a universalização dos serviços de água e esgoto. Esse é um dos principais fatores que explica a insatisfatória evolução dos índices de cobertura no país. Segundo estudo do Ministério das Cidades (2003) o país necessitará de $\mathrm{R} \$ 10$ bilhões anuais de investimentos até 2020 para conseguir universalizar os serviços de saneamento em cerca de 20 anos. O Programa de Aceleração do Crescimento (PAC) destinou R $\$ 40$ bilhões para a expansão dos serviços, porém, apenas $2 / 3$ das companhias públicas apresentaram garantias administrativas suficientes para dispor dos recursos. De 2003 a 2008, foram destinados R\$ 18 bilhões ao setor, entretanto, apenas R \$ 8,2 bilhões foram contratados, sendo que somente R 3 bilhões chegaram a ser investidos, segundo dados do Seminário Valor Setorial Saneamento (2008).

Diante das dificuldades das empresas públicas em tomar empréstimos, a união entre o poder público e o setor privado tornou-se uma opção viável para se obter outras fontes de recursos além do investimento público, de forma a criar condições que acelerem o ritmo de investimentos. Segundo o mesmo estudo, caso o país mantenha os níveis de investimento atuais, o Brasil levará 66 anos para ter serviço sanitário universal.

Com a aprovação da Lei de Concessões (1995), cujo objetivo é a outorga e autorização para o setor privado operar na exploração de serviços públicos e a Lei das Parcerias Público- 
privadas (2004), alguns municípios optaram por privatizar a prestação de serviços de saneamento básico. Essa opção significa maiores possibilidades de realizar investimentos por meio de novas garantias para concessão de crédito, desenvolvimento de operações financeiras e lançamento de títulos.

Há um crescimento da iniciativa privada no setor, atualmente, porém ainda tímido: dados da Abcon (2009), Associação Brasileira das Concessionárias Privadas dos Serviços Públicos de Água e Esgoto, indicam a existência de 207 contratos de concessão e parcerias público-privadas no Brasil, com impacto sobre 15 milhões de pessoas, aproximadamente $10,0 \%$ da população urbana brasileira, mas com capacidade de prestar serviços para 45 milhões nos próximos oito anos.

Apesar do predomínio das empresas públicas, o setor de saneamento possui uma estrutura de provisão dos serviços bastante heterogênea em que se misturam abrangência geográfica das empresas e diferentes naturezas jurídicas na forma de gestão. O SNIS permite identificar basicamente três grupos de prestadores, agrupados a partir de sua abrangência geográfica de atuação, que são: prestadores regionais, microrregionais e locais, cuja natureza jurídica pode ser tanto pública quanto privada.

As empresas que atendem a mais de um município ou geralmente regiões metropolitanas são chamadas de prestadores regionais ou empresas estaduais. De um total de 26 empresas desse tipo a maioria (23 delas) é sociedade de economia mista com predominância de capital e gestão pública. As empresas locais fornecem serviços de saneamento básico exclusivamente a um único município e podem ser públicas ou privadas. Dos 571 prestadores locais existentes, apenas 39 são empresas privadas e o restante são autarquias, departamentos e empresas municipais públicas. Por fim, os prestadores microrregionais atendem a uma pequena quantidade de municípios: dos oito prestadores existentes desse tipo, três são empresa privada e cinco são autarquias.

De acordo com a amostra do SNIS, para o ano de 2007, existem 171 municípios brasileiros atendidos por empresas privadas de saneamento, no sentido de que existe alguma forma de participação (total ou parcial) do capital privado na gestão de tais empresas, independente de sua abrangência geográfica de atuação.

Diante desse cenário, o objetivo dessa dissertação é realizar uma análise de desempenho entre os diversos prestadores de serviços de saneamento, principalmente com foco nos prestadores privados, que estão presentes no setor por meio das chamadas parcerias público-privadas. Deve-se tentar buscar uma configuração específica que seja dada pela inter- 
relação dos vários tipos de prestadores ou apontar o tipo de empresa que apresente o melhor desempenho na maioria dos indicadores. A qual(is) tipo(s) de empresa(s) ou associações possíveis entre elas devem ser direcionados os recursos do setor a fim de que não sejam desperdiçados sob formas de gestão ineficientes? Outras questões estão envolvidas na resposta de tal questionamento, tais como a reestruturação das empresas estaduais de saneamento que permita sua sustentabilidade econômico-financeira, a vigência efetiva do novo marco regulatório e a questão da eficiência das empresas prestadoras de serviços, pressuposto primordial da lei federal do Saneamento.

Para realização do objetivo proposto se verificará qual tipo de prestador apresenta melhor desempenho nos indicadores operacionais de água, operacionais de esgoto, indicadores econômicos, financeiros e administrativos, indicadores de investimento e de qualidade e analisar se os resultados obtidos condizem com as respectivas funções-objetivo de cada um deles enunciadas pela literatura do setor.

Por exemplo, de acordo com Parlatore (2000), as empresas públicas apresentam dificuldades associadas à otimização na distribuição de água em detrimento da produção. De fato, os resultados das estimações confirmaram que os operadores públicos registram maiores perdas de distribuição e de faturamento quando comparados com as empresas privadas. Essas empresas também tendem a ser mais produtivas que as públicas, em termos de menor despesa total com os serviços por $\mathrm{m}^{3}$ de água faturado e menor quantidade de empregados próprios por mil ligações de água e esgoto.

A análise empírica se valerá de estimação por Mínimos Quadrados Ordinários para 4.547 dados de corte transversal para o ano de 2007, uma vez que o cálculo dos indicadores, na média, para cada tipo de prestador, são inconclusivos quanto a uma resposta sobre qual tipo de empresa deve predominar no setor.

Os dados utilizados são provenientes do SNIS, Sistema Nacional de Informações sobre Saneamento, um banco de dados administrado na esfera federal, que contém informações de caráter institucional, administrativo, operacional, gerencial, econômico-financeiro e de qualidade sobre a prestação de serviços de água e esgotos. Os dados são atualizados anualmente para uma amostra de prestadores de serviços, desde o ano de referência 1995.

Os objetivos específicos desse estudo que servirão de base para a resposta da pergunta inicial são apresentados em quatro capítulos, além dessa introdução e conclusão. É importante ressaltar que os dois primeiros capítulos se destinam a fazer uma análise geral do setor em relação a sua importância, às características técnicas e econômicas que apresenta, a trajetória 
histórica que lhe configurou sua estrutura atual de provisão, o recente marco regulatório que marca o ambiente institucional, as parcerias público-privadas e a estrutura de oferta de provisão dos serviços predominante: tópicos destinados àqueles que não conhecem o funcionamento e características do setor de saneamento.

O terceiro capítulo apresenta revisão bibliográfica sobre os métodos que são utilizados para se medir eficiência no setor, algumas estatísticas descritivas em relação à cobertura do atendimento no país, o levantamento dos valores médios dos indicadores de desempenho por tipo de prestador, as funções-objetivo para os grupos de prestadores com base na literatura do setor e as tendências gerais do setor.

Por fim, no último capítulo, por meio de modelo econométrico para dados em cross section, são estimados os indicadores escolhidos e construídos em relação às estruturas de governança existentes, para verificar se os resultados são condizentes com aqueles verificados na teoria, e apontar uma tendência entre os prestadores que será mais favorável para o desenvolvimento do setor a fim de se estabelecer condições para que sejam alcançadas, de forma mais acelerada, as metas de universalização, no novo ambiente institucional inaugurado pelo marco regulatório. 


\section{Capítulo 1. A INDÚSTRIA DE SANEAMENTO BÁSICO}

\section{1) Importância do setor de saneamento básico.}

Em 2000, os Estados membros das Nações Unidas aprovaram a Declaração do Milênio, documento por meio do qual se comprometeram a atingir oito objetivos de desenvolvimento humano chamados de "objetivos do milênio": (i) erradicar a pobreza extrema e a fome; (ii) universalizar a educação fundamental; (iii) promover a igualdade entre os sexos e a autonomia das mulheres; (iv) reduzir a mortalidade infantil; (v) melhorar a saúde materna; (vi) combater o HIV/AIDS, a malária e outras doenças; (vii) garantir a sustentabilidade ambiental e (viii) criar uma parceria mundial para o desenvolvimento. $\mathrm{O}$ objetivo do milênio no qual se encontra a meta relacionada ao saneamento básico é o de número sete e, referente a ele, a décima meta a ser cumprida, estabelece uma redução à metade, até 2015, da proporção da população sem acesso permanente e sustentável a água potável e a saneamento básico. Os objetivos e metas definidos visam proporcionar melhores condições sócio-econômicas aos países que se empenharem em perseguí-los, uma vez que o resultado desse esforço se traduzirá em maiores níveis de bem estar à sociedade.

É possível, a partir da Declaração do Milênio, mostrar o tamanho da importância do setor de saneamento básico para o desenvolvimento de uma nação. Além do objetivo relativo à sustentabilidade ambiental, o cumprimento da meta número dez pode beneficiar outros objetivos do milênio, destacando-se a redução da mortalidade infantil. Além desta, a erradicação da pobreza extrema e o combate a malária e outras doenças, com destaque para as infecto-contagiosas, adquiridas pela ingestão de água contaminada ou transmitidas por condições sanitárias adversas que as propagam, também são favorecidas. Dessa forma, ao menos quatro objetivos do milênio seriam impactados positivamente pelo oferecimento ou melhora dos serviços de saneamento básico.

A conseqüência mais preocupante da falta ou do inadequado fornecimento dos serviços de saneamento básico é o impacto na saúde da população. Um município, bairro ou região deficiente de instalações sanitárias, que retrate um cenário de defecação a céu aberto, mau cheiro e ausência de água limpa e tratada, promove condições para a proliferação de inúmeras doenças infecto-contagiosas transmissíveis pela água. 
As doenças mais comuns desse tipo são a diarréia, cólera, leptospirose, hepatite e esquistossomose $^{1}$ e são responsáveis pelas principais causas de mortalidade infantil no país e no mundo, segundo Relatório de Desenvolvimento Humano (2006). Estudo publicado na revista Lancet (2007) mostrou que, na cidade de Salvador, em sete anos, o acesso à rede de esgoto passou de $26 \%$ para $80 \%$ dos domicílios e, nesse período, a taxa média de mortalidade de crianças com menos de três anos caiu $22 \%$.

Dessa forma, a inter-relação entre saneamento básico e saúde pública deve ser considerada pelas autoridades governamentais na formulação de políticas, pois segundo FUNASA, Fundação Nacional da Saúde (2009), cada real aplicado em saneamento representa R \$ 5 de economia em gastos com a saúde. Conseqüentemente, as regiões deficientes de tais serviços apresentarão maiores gastos em tratamento hospitalar na cura e prevenção, muitas vezes estéril para o indivíduo inserido em condições sanitárias adversas, dessas doenças.

Mendonça e Motta (2005) consideram que o acesso aos serviços de saneamento é medida preventiva que, além das externalidades positivas ao meio ambiente, evita os riscos e desconfortos das doenças e seriam mais justificáveis economicamente para contínua redução da mortalidade infantil do que a inocorrência em gastos defensivos nos serviços de saúde.

Em condições sanitárias adversas, os focos de pobreza são disseminados ou, em última instancia, torna-se praticamente impossível eliminá-los. Assim, as desigualdades sociais são reforçadas e a qualidade de vida e o direito do indivíduo exercer sua cidadania são inexistentes. O acesso universal a serviços sanitários de qualidade deve constituir em elemento efetivo de superação da pobreza (FERNANDOIS, 2009).

Neri (2008), ao utilizar dados do censo de 2000, com complemento da PNAD (Pesquisa Nacional por Amostra de Domicílios) de 2006, mostra que um impacto indireto do setor se dá sobre o capital humano refletido na queda da produtividade do trabalhador, que se afasta do trabalho por apresentar doenças relacionadas a saneamento e na diminuição do rendimento, freqüência e evasão de crianças em idade escolar, pelo mesmo motivo.

Além das externalidades geradas pelo setor, a importância de água tratada e encanada como bem essencial à sobrevivência humana toma uma dimensão ainda maior no contexto vivido atualmente de escassez de água doce em todo planeta. Relatório da Unesco (2009), agência da Organização das Nações Unidas (ONU) para Educação, Ciência e Cultura, divulga que, se as atuais tendências continuarem, mais da metade da população mundial - cerca de três bilhões de pessoas de pessoas - sofrerá escassez de água em 2025. No Brasil, onde existe

\footnotetext{
${ }^{1}$ Existem ainda os nematóides intestinais, as infecções dos olhos e da pele, teníases e doenças transmitidas por inseto vetor como malária, dengue e filariose.
} 
13,3\% da água potável do mundo, o desperdício chega a 70\%. Dados da Sabesp mostram que 17\% da água distribuída em São Paulo é perdida por dia em razão de vazamentos.

A água perdida e desperdiçada é um dos prejuízos ao meio ambiente gerados por sistemas de saneamento inadequados. As obras de saneamento, em si, provocam modificações ambientais pela construção de reservatórios para armazenar água bruta de fontes naturais que, na maioria das vezes, não coincide com as localizações de maior demanda. Essas obras também administram unidades de tratamento que geram resíduos que podem se tornar fonte de poluição se não forem dispostos adequadamente.

Contudo, o destino dos resíduos gerados por domicílios, indústrias e atividades agrícolas é o que mais preocupa os governantes e a sociedade como um todo. Se forem despejados in natura ou sem algum tratamento mínimo nos rios, contaminarão os lençóis freáticos causando impactos predatórios e irreversíveis ao meio ambiente, além de limitar os usos múltiplos dos recursos hídricos como a irrigação agrícola, a navegação e recreação e comprometer seriamente as condições de potabilidade da água para consumo.

Esse setor tem uma importante capacidade de geração de renda interna: regiões carentes de instalações sanitárias, em especial as praianas, ficam impedidas de investir em potencial turístico, uma vez que condições ambientais adequadas, preservação de paisagens e natureza, são pressupostos para o desenvolvimento desse tipo de atividade econômica. Mello (2008) realizou estudo de caso sobre a urgência do governo do Estado do Rio de Janeiro investir, em 1996, no potencial turístico da região de Búzios, Cabo Frio, Arraial do Cabo e São Pedro da Aldeia. Essa região sofria com os efeitos de precários serviços de saneamento: poluição das praias, transmissão de doenças e, além disso, interrupção e falhas dos serviços nos períodos de intensa atividade turística.

O setor industrial também é atingido já que, além do consumo humano, a água é usada como insumo do processo produtivo de muitos setores tais como fármacos, alimentos e bebidas e, em muitos processos industriais, para produzir vapor, gerar força motriz e realizar reações químicas. Portanto, um país que possua um sistema de saneamento adequado aproveita melhor seus recursos hídricos e maximiza os diversos usos da água.

Investir em saneamento gera um considerável impacto no crescimento da economia pelos seus efeitos multiplicadores enquanto setor de infra-estrutura. Vários estudos comprovaram essa relação: Aschauer (1989) estabeleceu empiricamente o positivo impacto da infra-estrutura de capital público na produtividade total dos fatores. Da mesma forma que, Canning (1999) e Demetriades e Mamuneas (2000), apesar de utilizarem diferentes métodos 
econométricos, mostraram que a infra-estrutura é importante para o aumento do produto agregado. Nesse contexto, por meio do estímulo ao setor de construção civil o investimento em obras de saneamento gera empregos (diretos e indiretos) e induz o desenvolvimento econômico de longo prazo no país.

Hiratuka et all (2009) estimaram, a partir da metodologia de insumo-produto, os impactos econômicos diretos e indiretos da expansão da produção e do investimento do setor de saneamento básico sobre a demanda intersetorial e a geração de renda e emprego na economia brasileira.

Supondo-se um aumento hipotético de $1 \%$ na demanda final por saneamento (em R\$ milhões) quando se leva em conta todos os efeitos (diretos e indiretos) envolvidos na cadeia produtiva, o valor da produção seria acrescido R 158,3 milhões, o PIB aumentaria em R \$ 94,3 milhões e seriam gerados 1.449 postos de trabalho, sendo 651 no próprio setor e 798 nos demais setores. Quando os autores estimam, por metodologia semelhante, os impactos que os investimentos em saneamento ofereceriam à economia brasileira concluem que tais impactos são intensivos em serviços, em especial construção civil e demais serviços prestados às empresas, além do considerável impacto sobre emprego, renda e arrecadação. Como exemplificado no estudo, cada R 1 bilhão de investimento no setor provocaria um aumento de R \$ 1,68 bilhão no valor da produção da economia, uma expansão de R \$245 milhões da massa salarial e R\$ 139 milhões em impostos diretos e indiretos.

Nesse contexto, por meio do estímulo ao setor de construção civil e demais impactos, acima listados, o investimento em obras de saneamento gera empregos (diretos e indiretos) e estimula o desenvolvimento econômico de longo prazo no país.

Portanto, pode-se dizer que possuir um sistema de saneamento adequado é condição necessária, mas não suficiente, para o desenvolvimento social e econômico do país. Porém, não possuí-lo ou tê-lo precariamente não gera apenas estagnação, pois contribui para a deterioração crescente das condições sociais em termos de dignidade humana e qualidade de vida e, o mais preocupante, aborta ações que se destinem a promover o crescimento econômico e a sustentabilidade ambiental. 


\section{2) Característica técnicas e econômicas do setor.}

O novo marco regulatório do setor de saneamento expresso pela lei federal número 11.445, de janeiro de 2007, estabelece saneamento básico como o setor que contempla abastecimento de água, esgotamento sanitário, limpeza urbana e manejo de resíduos sólidos, drenagem e manejo de águas pluviais. Algumas características de tais serviços os definem como serviços públicos de infra-estrutura que os conferem especificidades em relação à formas de provisão e regulação econômica.

A preocupação teórica com os serviços de utilidade pública (public utilities) é tipicamente norte-americana. Nos Estados Unidos, ampla literatura foi desenvolvida nas décadas de 20, 30 e 40 desse século, pois, diante da tradição liberal dominante, era necessário apresentar-se justificativa, jurídica e econômica convincente, da intervenção do Estado em atividades econômicas. Essa justificativa se constitui em nome do "interesse público" envolvido nessas atividades (SAES, et all, 1996).

Jones e Bigham (1939), citados por Saes, et all (1996), advertem que os serviços de utilidade pública têm certas características não possuídas pelas empresas ordinárias. Tais características não são, em cada caso, peculiares dos serviços de utilidade pública, mas consideradas em conjunto são suficientemente importantes para colocar a indústria numa categoria própria. As características listadas pelo autor são apresentadas a seguir:

- Essa indústria é formada por empresas que fornecem um serviço indispensável à população, cuja substituição não pode ser facilmente realizada e a interrupção de fornecimento provocaria danos substanciais à mesma. Diz-se, nesse caso, que se trata de um bem essencial ou necessário ${ }^{2}$.

- Os serviços de utilidade pública geralmente constituem-se monopólios naturais, estrutura de mercado que apresenta economias de escala, custo médio por unidade produzida decrescente, para um determinado ramo de produção. Conseqüentemente, a atuação de uma ou poucas empresas é mais vantajoso tanto pela limitação de espaço, mas, principalmente, pela possibilidade de prestar o serviço com tarifas mais baixas do que em regime de concorrência. Nesse caso, a existência de um número maior de

\footnotetext{
${ }^{2}$ Varian (2003) define que quando a demanda por um bem aumenta com menor rapidez (ou em menor proporção) do que o aumento da renda tem-se um bem necessário.
} 
empresas pode levá-las a incorrer em custos médios superiores aos de um monopolista.

- Os serviços de utilidade pública estão sujeitos a completo controle por várias agências do governo, por decorrência de seu caráter monopolista.

- Os investimentos necessários para o oferecimento de tais serviços necessitam de enormes volumes de capital.

- As empresas auferem rendimentos bastante estáveis, até mesmo crescentes, devido ao crescimento (e atratividade) do negócio.

Dentre essas características dos serviços de utilidade pública, levantadas pelos autores norte-americanos, a característica do monopólio natural foi escolhida pela Teoria Econômica como a principal justificativa para a necessidade de regulamentação e controle dessas atividades pelo governo, quando os mercados falham no cumprimento do objetivo da eficiência.

A eficiência no sentido de Pareto que, conseqüentemente, leva à máxima alocação dos recursos e bem-estar do consumidor, muitas vezes não se mantém, devido à violação dos pressupostos para o funcionamento de um mercado perfeitamente competitivo (preço dado no mercado, produção de produtos homogêneos e livre entrada e saída da indústria). Quando isso ocorre diz-se que os mercados falham e tais falhas segundo, Pindyck e Rubinfeld (2006) são provocadas por quatro razões básicas: poder de mercado, informação incompleta, externalidades e bens públicos.

Um produtor dotado de poder de mercado determina a quantidade produzida igualando a receita marginal (em vez do preço) ao custo marginal e vende uma quantidade menor por um preço mais elevado do que aquele que seria praticado em um mercado competitivo. Um dos fatores que determinam o poder de monopólio das empresas é a elasticidade da demanda com que essa se depara, ou seja, quanto menos elástica for a curva de demanda da empresa, maior poder de monopólio ela terá. Se existe apenas uma única empresa oferecendo determinado bem, sua curva de demanda será a curva de demanda do mercado.

O segundo fator determinante da curva de demanda de uma empresa (e, portanto, de seu poder de monopólio) é o número de empresas atuantes no mercado. Quanto mais empresas competirem entre si, maiores serão as dificuldades encontradas por elas para aumentar preços e evitar a perda de vendas para concorrentes. Dessa forma, uma estratégia competitiva implantada é a identificação de meios que possam atuar como barreiras a entrada, condições que impeçam ou desestimulem a entrada de novos concorrentes. 
Em muitas estruturas de mercado monopolísticas, ocorrem as chamadas barreiras naturais, provenientes de uma situação em que é mais vantajoso, em termos de custo, a operação de uma única empresa atuante no mercado a várias delas competindo entre si. Nesse caso, têm-se os chamados monopólios naturais. O termo "monopólio natural" implica que o resultado "natural" das forças de mercado é o desenvolvimento de uma organização de monopólio (GIAMBIAGI e ALÉM, 2000).

Pires e Piccinini (1999) definem os serviços de utilidade pública como monopólio natural pelo fato de serem muito intensivos em capital, ou seja, exigem uma rede de infraestrutura física que apresenta elevados custos para ser construída e mantida. Além disso, destacam que a execução de projetos desse porte envolve longo prazo de maturação, investimentos de alta especificidade e significativos custos irrecuperáveis (sunk costs). Portanto, em dadas circunstâncias, a operação de uma única firma atuante no mercado minimiza custos, uma vez que a existência desse tipo de monopólio se dá, sobretudo, em virtude da existência de economias de escala ${ }^{3}$, densidade ${ }^{4}$ e/ou de escopo ${ }^{5}$ presentes na maioria dos serviços públicos de infra-estrutura.

Nesse contexto, o setor de saneamento básico configura-se um monopólio natural por atender a todas as características apresentadas. $\mathrm{O}$ setor apresenta elevados investimentos indivisíveis e de longa maturação necessários ao funcionamento de sua rede de operação. O ciclo inicia-se com a construção de reservatórios que coletam a água bruta armazenada em lagos e rios, depois ocorre o transporte da água até a planta ou estação de tratamento, a implantação dos processos para que a mesma seja potável, o direcionamento da mesma para a rede de distribuição a fim de abastecer os pontos de consumo e, por fim, o tratamento do descarte da água já utilizada somado às águas pluviais de forma que esteja minimamente despoluída para ser devolvida ao meio ambiente.

Os custos fixos envolvidos no ciclo de saneamento são muito elevados e irrecuperáveis devido à alta especificidade dos ativos. Por outro lado, os custos variáveis relativos à manutenção do sistema e aos gastos com materiais de tratamento somam um montante relativamente menor. Dado que o volume de produção de água ocorre em larga

\footnotetext{
${ }^{3}$ As economias de escala ocorrem quando é possível dobrar o nível de produção com o dobro dos custos. Como os custos não chegam a aumentar proporcionalmente à produção, o custo marginal é menor que o custo médio e, portanto, o custo unitário por unidade produzida será decrescente.

${ }^{4}$ Os ganhos de densidade se resumem a menores custos quanto maior o adensamento de usuários numa determinada região.

${ }^{5}$ Ocorrem quando a produção conjunta de uma única empresa é maior do que aquilo que poderia ser produzido por duas empresas diferentes, cada uma das quais gerando um único produto.
} 
escala, após instalado todo o capital físico necessário à infra-estrutura do setor, verifica-se um custo médio declinante no ramo de produção economicamente viável.

A segunda característica que justifica a regulação econômica e/ou intervenção do Estado no setor (também considerada uma falha de mercado) são as externalidades: transações entre produtores e consumidores que produzem efeitos positivos ou negativos a terceiros. Como apresentado na seção anterior, os serviços de saneamento geram externalidades na área da saúde pública, meio ambiente, qualidade de vida e crescimento econômico e, portanto, dão origem a custos ou benefícios não refletidos nos custos de produção, levando, conseqüentemente, à super ou sub-exploração dos recursos. O papel da regulação é de avaliar os custos externos e redistribuí-los aos que lhe deram origem.

Por fim, a última fonte de falha de mercado, também presente na indústria de saneamento, é o fato dos serviços de saneamento básico constituírem um bem público. De acordo com Giambiagi e Além (2000), os bens públicos são aqueles cujo consumo ou uso é indivisível ou "não-rival", ou seja, o consumo por parte de um indivíduo ou um grupo da sociedade não prejudica o consumo dos mesmos bens pelos demais agentes. Além disso, esses bens também apresentam a característica da "não-exclusão": não é possível impedir que um indivíduo usufrua de um bem público. Nesse sentido, esse princípio torna a solução de mercado, em geral, ineficiente para garantir a produção da quantidade adequada de bens públicos requerida pela sociedade: num equilíbrio voluntário, muito pouco do bem público será suprido, pois uma pessoa tenderá a pegar carona na contribuição da outra que estiver provendo o bem público (VARIAN, 1999, p.733).

Em todos esses casos apresentados fica evidente que o mecanismo de mercado por si só, como prediz a teoria econômica clássica, não é capaz de garantir uma solução eficiente em termos de bem-estar para os consumidores, justificando a existência do governo para guiar, corrigir e complementar o sistema de mercado.

O governo está presente majoritariamente no setor de saneamento básico brasileiro, pois é responsável pela provisão dos serviços em aproximadamente $70 \%$ dos municípios do país, segundo dados do SNIS (Sistema Nacional de Informações sobre Saneamento) de 2007. Contudo, em decorrência da demanda crescente por tais serviços, que aumentou juntamente com as taxas de urbanização e crescimento populacional registrados nas últimas décadas, a insuficiência do setor é histórica na realidade brasileira. Os indicadores relativos aos serviços de água e esgoto ainda estão muito aquém do necessário e longe de alcançar as metas de universalização para todas as regiões e municípios brasileiros como um todo. 
Portanto, para que se atinja esse objetivo é necessário cumprir os mecanismos de regulação ${ }^{6}$, que evitem a obtenção de lucros extraordinários por parte das empresas monopolistas, que estabeleçam regras para garantia dos contratos, que estimule o aumento da capacidade de investimento por parte dos diversos tipos de empresas atuantes no setor e que, principalmente, crie condições seguras para aumentar a participação do setor privado, por meio dos diversos tipos de parcerias público-privadas, que consigam alavancar recursos e promover as bases da tão esperada e necessária universalização.

\section{3) Trajetória histórica}

No Brasil, de 1850 ao início da década de 1930, os serviços de saneamento eram prestados de acordo com um modelo no qual participavam setor público e empresas privadas. O Estado delegava a exploração dos serviços a concessionárias estrangeiras que eram responsáveis pela prestação de vários serviços de utilidade pública, entre eles, àqueles relacionados a saneamento: abastecimento de água e esgotamento sanitário.

A participação privada se dava pela construção de fontes particulares de acesso gratuito ou restrito, ou pela atividade dos aguadeiros que promoviam o comércio da água com entrega domiciliar em barris. As ações estatais se limitavam a fixação de tarifas e garantia mínima de rentabilidade para os investidores estrangeiros que não encontravam restrições por parte do governo para importar máquinas e equipamentos e remeter lucros para a matriz

No início dos anos 30, após o país ter sofrido os efeitos da crise de 1929, a demanda do mercado interno assumiu papel decisivo na determinação da renda e emprego da economia. Em decorrência do maior ritmo de urbanização, houve maior crescimento populacional e a necessidade de que o setor público expandisse os serviços de infra-estrutura. Em 1934, o governo federal lançou o Código de Águas que lhe proporcionou a intervenção no setor de saneamento por meio da fixação de tarifas, nacionalização e estatização das empresas estrangeiras, conferindo ao setor público a possibilidade de controlar e incentivar o aproveitamento industrial das águas.

Durante as décadas de 40 e 50, a intervenção governamental iniciada anteriormente se tornou mais intensa. Os serviços de saneamento passaram a ser de responsabilidade das

\footnotetext{
${ }^{6}$ Em vigor com a nova lei federal número 11.445 de janeiro de 2007.
} 
prefeituras municipais e, no âmbito federal, foi criada a Fundação Serviço Especial de Saúde Pública (FSESP), para levar os serviços de água e esgoto a regiões de baixa renda e promover programas de educação sanitária. Quanto aos departamentos, foram reformulados o Departamento Nacional de Obras de Saneamento (DNOS) e o Departamento Nacional de Obras contra as Secas (DNOCS).

Os municípios, que não tinham anteriormente seus sistemas autônomos e departamentos, passaram a assumir a prestação dos serviços por meio dos SAAEs (Serviços Autônomos de Água e Esgoto) ou então forneciam os serviços de saneamento em conjunto com outros municípios vizinhos. Esses municípios recebiam pequenas e esporádicas transferências dos governos estaduais e federal, de modo que aqueles dotados de maior capacidade financeira tinham mais recursos para investir na provisão e operação dos serviços.

Contudo, já naquela época se verificava a incompatibilidade entre os baixos níveis de investimento no setor e o bom desempenho econômico do período, que contava com um considerável nível de industrialização e com elevadas taxas de crescimento do PIB (MPO/Sepurb/IPEA, 1995, p. 78). A presença estatal na economia continuou atuante, com a criação, em 1942, da Companhia Siderúrgica Nacional (CSN) e, no mesmo ano, da Companhia Vale do Rio Doce (CVRD). Em 1952, foi criado o do Banco Nacional de Desenvolvimento Econômico, BNDE (posteriormente BNDES), cujo principal objetivo era fornecer financiamento para o setor de infra-estrutura e, em 1953, houve a criação da Petrobrás. Essas ações representaram um passo importante para o desenvolvimento industrial do país e uma confirmação de que o setor privado não teria condições de arcar com tamanho investimento.

Contudo, a situação econômica próspera da época se reverteu após 1962 e perdurou instável até 1967. Num cenário econômico turbulento, a subida inflacionária aliava-se às indefinições políticas e a um período de desaceleração do PIB.

O Plano Trienal de Desenvolvimento, promulgado em 1962, mas planejado para o triênio 1963/5, contribuiu para o diagnóstico dos principais problemas econômicos do início dos anos 60, apesar de ter sido abandonado antes da tomada do poder pelos militares. Nesse sentido, o Plano, após levantamento do Departamento Nacional de Saúde da situação do setor, enunciava a necessidade de um montante de investimento para apoiar programas relacionados a saneamento.

Foi dessa forma que foram lançadas as bases para uma Política Nacional de Saneamento uma vez que já se havia constatado que a falta ou a inadequação desse tipo de infra-estrutura comprometeria os objetivos de desenvolvimento econômico de longo prazo do país. 
Quando os militares assumiram o poder, em 1964, foi formulado o Programa de Ação Econômica do Governo (PAEG) para o período de 1964/6. Dentro das inúmeras medidas de sucesso do Programa, é possível listar várias delas que colaboraram para o desenvolvimento do setor. De uma forma explícita, o PAEG pretendia elevar o índice de atendimento aos serviços de saneamento, tanto em relação ao abastecimento de água quanto à coleta e tratamento de esgoto ${ }^{7}$. Porém, mais importante que isso, foi o lançamento das medidas que proporcionaram as bases para o desenvolvimento futuro do setor.

Uma das principais destas medidas foi a criação do Banco Nacional de Habitação (BNH), promulgada pela Lei $\mathrm{n}^{0} 4.380$, no dia 21 de agosto de 1964, cujo objetivo era desenvolver uma política nacional urbana de habitação por meio da realização de operações de crédito, principalmente crédito imobiliário. O BNH não lidava diretamente com o público, e sim atuava por intermédio de outros bancos (públicos e/ou privados) e de outros agentes, tais como companhias habitacionais e companhias de água e esgoto.

Além da criação do BNH, o PAEG se empenhou na busca de empréstimos do Banco Interamericano de Desenvolvimento (BID) para implantação do primeiro programa federal de financiamento do setor chamado Programa de Abastecimento de Água para Pequenas Comunidades. De acordo com esse programa, seriam financiados $50 \%$ dos investimentos necessários à construção de sistemas de abastecimento de água em cidades com menos de 40 mil habitantes.

Em 1966, a Lei $\mathrm{n}^{\mathrm{o}} 5.107$ criou um importante mecanismo financeiro, o Fundo de Garantia de Tempo de Serviço (FGTS) ${ }^{8}$ que, por meio de desconto mensal de $8 \%$ sobre o salário dos empregados, tinha o objetivo de servir de indenização aos trabalhadores demitidos pelas empresas e também gerar um fundo que mais tarde viria a dar suporte à política de saneamento básico.

A Lei $n^{0} 5.172$, que passou a vigorar em 1967, reduziu a receita disponível de estados e municípios e concentrou os recursos públicos na esfera da União, modificando o Sistema Tributário Nacional. No mesmo ano, o Ministério do Interior foi responsável pela formulação e implantação de uma Política Nacional de Saneamento, enunciada pelo Decreto Lei ${ }^{0} 200$. Antes disso, não havia diretrizes estabelecidas para aplicação de recursos federais, esses ocorriam de forma pulverizada.

\footnotetext{
${ }^{7}$ Dentro da parte de desenvolvimento social e valorização regional.

${ }^{8}$ O Fundo de Garantia do Tempo de Serviço (FGTS), instituído pela Lei no 5.107, de 13 de setembro de 1966, passa a reger-se pela lei no 8.036, de 11 de maio de 1990.
} 
Nessa época, no âmbito do BNH, foi criado o Sistema Financeiro de Saneamento (SFS) que tinha o objetivo de centralizar recursos e coordenar ações no setor. Inicialmente, esse fundo continha apenas recursos do Banco Nacional de Habitação e dotações orçamentárias (a fundo perdido) do governo federal. Com a criação do Decreto Lei ${ }^{\circ}$ 949, o BNH podia aplicar os recursos do FGTS no setor de saneamento básico.

Juntos, BNH e SFS, entre 1968 e 1970, implantaram diversas medidas que contribuíram para uma efetiva Política Nacional de Saneamento na década posterior. Entre as medidas realizadas, as mais importantes foram o estímulo à criação de Companhias Estaduais de Saneamento Básico (CESBs) e à criação de fundos estaduais de água e esgoto (FAEs), compostos de recursos estaduais e do BNH. Além disso, foi criado o Fundo de Financiamento para o Saneamento, constituído de vários subprogramas que recebiam recursos do FGTS, de empréstimos externos e de contribuições a fundo perdido do orçamento federal.

A despeito desse avanço institucional, os baixos níveis de investimento refletiram índices de atendimento insatisfatórios em termos de cobertura. As experiências iniciais do SFS mostraram a fragilidade do modelo de gestão dos serviços de saneamento: funções públicas pulverizadas, desconexas e sem planejamento sistemático. As operações de financiamento não contavam com um nível de controle operacional complexo e com uma organizada estrutura administrativa do agente financeiro (BNH). Outros fatores como regulação minimamente adequada, falta de escala e baixo nível dos projetos elevaram os riscos de sustentabilidade e eficácia do SFS.

A partir das diretrizes e fatores institucionais lançados no período de 1968/70, o Banco Nacional de Habitação, em 1971, implementou um programa centralizado para financiar o setor: o Plano Nacional de Saneamento (PLANASA). Com esse plano, a prestação dos serviços de saneamento básico no Brasil passou da esfera municipal, que contava com restrições orçamentárias e oferta insuficiente, para a estadual. Os Estados, através das recémcriadas CESBs, obtiveram contratos de concessão dos municípios por 30 anos, eram responsáveis pela execução de obras e operação dos sistemas e tinham acesso exclusivo aos recursos destinados ao setor de saneamento pelo $\mathrm{BNH}$.

Os municípios não eram obrigados a delegar a prestação de serviços às CESBs, mas o acesso aos financiamentos do $\mathrm{BNH}$ e aos subsídios cruzados ${ }^{9}$ eram bastante atrativos para executar essa mudança. Mesmo assim, muitos preservaram a responsabilidade pela prestação dos serviços, tanto na forma de empresas municipais, autarquias ou departamentos.

\footnotetext{
9 Transformação do excesso de receita de municípios superavitários em uma forma de subsídio para os municípios deficitários (aqueles que não podem pagar uma tarifa que cubra seus custos).
} 
O BNH, organismo responsável pelo Sistema Financeiro de Saneamento (SFS), tinha o papel de controlar, normatizar, coordenar, aprovar os Planos Estaduais de Saneamento e, sobretudo, buscar empréstimos juntamente ao Fundo de Garantia por Tempo de Serviço, para financiar $50 \%$ dos recursos destinados ao setor. A outra metade viria das FAEs, fundo de origem tributária estadual que também continha recursos do BNH.

$\mathrm{O}$ arranjo institucional e o esquema de financiamento, a partir de um planejamento global de ações no setor, propostos pelo PLANASA, obtiveram sucesso. O aumento significativo dos índices de cobertura se deu principalmente na esfera da distribuição de água, uma vez que exige menores custos e apresenta retornos tarifários mais rápidos, e se concentrou nas regiões Sul e Sudeste do país, em regiões mais populosas e nos segmentos de maior renda.

Segundo tabela 1.1 abaixo, a primeira coluna mostra que, na década de 70 , foram aplicados pelo PLANASA mais de $0,46 \%$ do PIB em obras de abastecimento de água e esgoto. Esse valor se mostra bastante significativo ao compararmos com as porcentagens dos outros anos, com exceção de 1998.

Tabela 1.1 - Formação Bruta de Capital Fixo em setores de infra-estrutura (em \% do PIB)

\begin{tabular}{lcccccccccc}
\hline & $1970-80$ & $1981-89$ & $1990-92$ & $1993-94$ & 1995 & 1996 & 1997 & 1998 & 1999 & 2000 \\
Energia Elétrica & 2,13 & 1,47 & 1,01 & 0,69 & 0,47 & 0,57 & 0,69 & 0,89 & 0,77 & 0,67 \\
Telecomunicações & 0,80 & 0,43 & 0,45 & 0,55 & 0,53 & 0,79 & 0,78 & 1,18 & 1,17 & 1,07 \\
Transportes & 2,03 & 1,48 & 0,83 & 0,54 & 0,42 & 0,53 & 0,61 & 0,75 & 0,56 & 0,63 \\
Saneamento & 0,46 & 0,24 & 0,10 & 0,03 & 0,10 & 0,16 & 0,28 & 0,35 & 0,20 & 0,21 \\
Total & 5,42 & 3,62 & 2,39 & 1,81 & 1,52 & 2,05 & 2,36 & 3,17 & 2,70 & 2,58 \\
\hline Fonte: Bielschowsky
\end{tabular}

Fonte: Bielschowsky (2002).

Segundo Censos Demográficos 1970, 1980, 1990 e 2000 (IBGE) o atendimento de abastecimento de água passou de 60,5\% da população urbana, em 1970, para 79,2\%, em 1980 atingindo 86,3\%, em 1990. Nesse mesmo período, a cobertura dos serviços de coleta de esgoto passou de $22,2 \%$ da população urbana para 47,9\%, em 1990, informações resumidas em tabela 1.2 abaixo; 
Tabela 1.2 - Evolução da cobertura dos serviços de água e esgoto no Brasil (\%)

\begin{tabular}{lrrrrr}
\hline Indicadores & 1970 & 1980 & 1990 & 2000 \\
\hline Abastecimento de água & & & & \\
domicílios urbanos - rede de distribuição & 60,50 & 79,20 & 86,30 & 89,80 \\
domicílios rurais - rede de distribuição & 2,60 & 5,00 & 9,30 & 18,10 \\
Esgotamento sanitário & & & & \\
domicílios urbanos - rede de coleta & 22,20 & 37,00 & 47,90 & 56,00 \\
domicílios urbanos - fossas sépticas & 25,30 & 22,90 & 20,90 & 16,00 \\
domicílios rurais - rede de coleta & 0,45 & 1,40 & 3,70 & 3,30 \\
domicílios rurais - fossas sépticas & 3,20 & 7,20 & 14,40 & 9,60 \\
\hline
\end{tabular}
Fonte: Bielschowsky (2002).

A instituição PLANASA previa que o papel do Banco Nacional de Habitação fosse diminuído gradativamente e, em seu lugar, os Fundos de Água e Esgoto se tornariam responsáveis pelos investimentos por meio do fluxo de tarifas gerado.

Apesar do grande avanço verificado, a extinção do BNH provocou, a partir da segunda metade da década de 1980, grande deterioração do setor e impossibilitou a realização de novos investimentos. O cenário econômico era de término das fontes de financiamento e de dificuldades macroeconômicas. Em particular, o início dos anos 80 foi marcado pela crise da dívida externa e pelo esgotamento do modelo adotado pelas empresas estatais de serem financiadoras do desenvolvimento econômico do país. A combinação das elevadas taxas de inflação, nesse período, juntamente com o estancamento de recursos externos evidenciou a deterioração das contas públicas do governo que já vinha se formando desde a década anterior.

Além dos agravantes econômicos, a ênfase do PLANASA na área de construção de novos sistemas em detrimento do setor de operações, que não era financiado pelo BNH, levou a uma posterior degradação dos mesmos e a um índice bastante elevado de perdas de água (OHIRA e TUROLLA; 2005). Outros fatores que contribuíram para essa degradação foram a expansão urbana acelerada sem planejamento, a ineficiência operacional decorrente dos elevados custos financeiros e das perdas de faturamento, deficiências na gestão comercial, as dificuldades relativas à auto-sustentação, quando se começou a atender os estratos de menor renda, e uma política tarifária irrealista que se aproveitou do controle das tarifas públicas como instrumento de redução de tensões inflacionárias ou de populismo eleitoral.

Em 1986, as funções do BNH passam a ser administradas pela Caixa Econômica Federal, iniciando o processo que levou ao término do PLANASA. A atividade reguladora, 
exercida anteriormente pelo $\mathrm{BNH}$, ficou sob responsabilidade de diversos ministérios fragmentando a política de saneamento.

No início dos anos 90 ocorre a efetiva extinção do PLANASA e a revogação do Decreto $n^{0} 82.587$ leva as empresas estaduais ao processo de auto-regulação que existia anteriormente, corroborando o vazio institucional no setor.

Nesse contexto de crise econômica e em meio ao processo de fragilidade do setor público, as conseqüências trazidas pela Constituição de 1988 foram um agravante para a crise fiscal. Dentre essas, pode-se citar a promoção de um movimento organizado em favor da descentralização de receitas, ou seja, as esferas subnacionais tiveram um aumento de suas competências tributárias e, além disso, houve também um aumento das transferências intergovernamentais. Nesse processo, os municípios foram beneficiados e fortalecidos financeiramente.

Contudo, do lado das despesas, não houve a formulação de um plano nacional que pensasse a descentralização dos gastos. Isto é, os municípios passaram a assumir uma importância cada vez maior no gasto público, mesmo quando não tinham capacidade administrativa para execução dessa função. Esse arranjo gerou uma série de lacunas na provisão dos serviços públicos, inclusive no setor de saneamento.

Além disso, foi implementado um dispositivo pela Constituição de 1988, que definiu que os municípios seriam responsáveis pelos serviços de saneamento prestados localmente, fato que levantou a questão da indefinição relativa à titularidade da prestação dos mesmos ${ }^{10}$. É importante notar que, no período pós-PLANASA, foi permitido que os municípios tivessem acesso aos recursos do FGTS, ainda que limitados, para financiar seus investimentos, algo que anteriormente seria permitido somente às CESBs.

Na década de 90, segundo Ohira e Turolla (2005), as políticas públicas caracterizaramse pela ênfase na modernização e ampliação marginal da cobertura dos serviços. Esse fato pode ser demonstrado por um conjunto de programas federais, que podem ser enquadrados em dois conjuntos de ações.

O primeiro conjunto de ações é voltado para a redução das desigualdades sócioeconômicas em detrimento de sistemas que apresentavam viabilidade econômico-financeira. O segundo é voltado para a modernização e desenvolvimento institucional dos sistemas de saneamento. Segundo os autores, a novidade da década de 90, foi a linha de aperfeiçoamento institucional que passou a direcionar os programas destinados ao setor. Dessa forma, a ação

\footnotetext{
${ }^{10}$ A nova lei federal, $\mathrm{n}^{\circ}$ 11.445, não resolveu essa indefinição da titularidade dos serviços de saneamento em regiões metropolitanas, questão que será discutida no capítulo 2.
} 
modernizante incluiu o incentivo à realização de concessões à iniciativa privada, mesmo com indefinições no marco regulatório vigentes na época.

Contudo, com o objetivo de atingir uma maior flexibilidade institucional e uma maior eficiência na distribuição dos recursos, as inúmeras reformas administrativas promovidas no período reforçaram o processo de desregulamentação do setor. Algumas medidas importantes foram tomadas a fim de evitar essa situação tais como a criação do Projeto de Lei da Câmara 199 (PLC 199) e, principalmente, a criação do Programa de Modernização do Setor de Saneamento (PMSS).

O PMSS foi criado em 1993 com recursos provenientes de um empréstimo obtido pela União junto ao Banco Internacional para Reconstrução e Desenvolvimento (BIRD), no âmbito da Secretaria de Política Urbana (Sepurb) do Ministério do Planejamento e Orçamento (MPO). Desde 2003, a execução do PMSS está sob responsabilidade da Secretaria Nacional de Saneamento Ambiental (SNSA) do Ministério das Cidades (MC). O principal objetivo do programa é a modernização do setor de saneamento via aumento da eficiência e da capacidade de financiamento da prestação dos serviços a fim de promover a universalização dos mesmos. Dentre seus objetivos específicos estão ${ }^{11}$ :

(i) o fornecimento de suporte técnico aos órgãos e entidades do setor a fím de promover reformas institucionais que melhorem a qualidade e o nível de eficiência e eficácia de suas ações ${ }^{12}$.

(ii) promover estudos de arranjos alternativos de gestão que permitam o fortalecimento do prestador de serviço atual;

(iii) instituir ações de capacitação dos agentes que atuam no setor de saneamento como, por exemplo, o processo de criação e estruturação da Rede Nacional de Capacitação e Extensão Tecnológica em Saneamento Ambiental - ReCESA;

(iv) cumprir o papel de vanguarda em temas emergentes para o setor tais como o alcance das Metas do Milênio e o cumprimento de tratados internacionais;

(v) atuar na instituição do marco legal e regulatório para o setor ${ }^{13}$;

\footnotetext{
${ }^{11}$ Informações contidas em relatório final apresentado pelo Ministério das Cidades intitulado "O Programa de modernização do Setor de Saneamento (PMSS) - transição para uma estrutura permanente".

12 Público-alvo beneficiado: estados e municípios, instâncias de regulação e fiscalização e prestadores públicos de serviços. Entre eles, o PMSS fornece assistência técnica e de logística na implementação do projeto de Cooperação Internacional Brasil-Itália em Saneamento Ambiental.

${ }^{13}$ Vale destacar que o PMSS contribuiu para a discussão e aprovação de duas leis importantes para o setor: a Lei 11.107/2005, que regulamenta os Consórcios Públicos e a Lei 11.445/2007, que institui a política federal de saneamento básico.
} 
(vi) desenvolver e aperfeiçoar o seu mais reconhecido produto que é o Sistema Nacional de Informações sobre Saneamento (SNIS), maior banco de dados do setor cujas informações cedidas por uma amostra de prestadores de serviços, tanto de água e esgoto quanto de resíduos sólidos, que a cada ano amplia seu tamanho e representatividade.

Dessa forma, ao longo dos seus dezesseis anos de existência, o PMSS consolidou-se como instrumento de apoio à instância executiva da política de saneamento do Governo Federal, essencial para o desenvolvimento do setor e, conseqüentemente, para o futuro do país.

A década de 90 trouxe a necessidade de sanar a situação fiscal do governo e os elevados índices inflacionários. Além das tentativas de inúmeros planos de estabilização fracassados, destaca-se no período, o início do processo de abertura econômica e um amplo processo de privatizações.

O Plano Real tentou implementar um ajuste fiscal em sua primeira fase. Contudo, esse ajuste não se sustentou, pois o déficit público passou a apresentar uma trajetória de crescimento após 1997 e a divida mobiliária federal apresentou uma trajetória explosiva. De acordo com esse cenário de desequilíbrio das contas públicas, surgiu a Lei de Responsabilidade Fiscal (LRF), tentativa de orientar o comportamento das finanças das autoridades dos três níveis de governo.

Dada a completa incapacidade de investimento do Estado, nos anos 90, o processo de privatizações brasileiro passou a determinar um papel de destaque na economia. Esse processo foi representado pelo Plano Nacional de Desestatização cujos objetivos eram:

- reordenação da posição estratégica do Estado, transferindo à iniciativa privada atividades indevidamente exploradas pelo setor público,

- políticas que visassem à diminuição da dívida pública,

- permitir a retomada de investimentos nas empresas e atividades que viessem a ser transferidas à iniciativa privada,

- permitir que a Administração Pública concentre seus esforços nas atividades em que a presença do Estado seja fundamental para a consecução das prioridades nacionais,

- modernização do parque industrial do país,

- contribuição para o fortalecimento do mercado de capitais.

Com a aprovação da Lei de Concessões, número 8.987, de fevereiro de 1995, marca-se uma fase crucial no plano de privatizações dos serviços públicos com a negociação de 
concessões em setores interessantes para o setor privado, entre eles, o setor de saneamento básico.

Turolla (2002) afirma que, na época, a principal conseqüência da ação modernizante, promovida com a introdução dos diversos programas federais voltados para o aumento da cobertura, foi o descompasso causado pelo incentivo ao processo de privatização sem que houvesse a definição do marco legal específico. Apesar desse impasse, o esforço da ação modernizante foi muito proveitoso a fim de lançar base para ações futuras de políticas públicas. Nesse contexto, houve um aprimoramento no âmbito do PMSS (Programa de Modernização do Setor de Saneamento), do SNIS (Sistema Nacional de Informações em Saneamento) e uma integração da política de saneamento com as políticas de desenvolvimento urbano, de saúde e de meio ambiente. Contudo, o autor destaca que, "o setor ampliou sua cobertura nos anos 1990, mas conservou intactas as feições que lhe foram conferidas pelo PLANASA" (TUROLLA, 2002, p. 15).

$\mathrm{Na}$ última década, surgiram várias formas de participação privada no setor de saneamento básico brasileiro, cujo objetivo é propor alternativas às dificuldades encontradas pelo mesmo no cumprimento das metas de universalização.

Dados recentes da última Pesquisa Nacional de Amostras e Domicílios (Pnad), evidenciados na tabela $1.3^{14}$, indicam que o Brasil conseguiu alcançar em 2007, a meta do milênio relativamente ao acesso à água potável nas áreas urbanas ${ }^{15}$, prevista para 2015 , uma vez que existe água canalizada de rede geral no interior do domicílio de 91,3\% dos moradores de diversas cidades do país. No último ano, foi possível levar água de rede geral para quase 2,2 milhões de brasileiros: 2 milhões residentes em áreas urbanas e 198 mil moradores de zonas rurais.

Contudo, algumas ressalvas devem ser feitas em relação às disparidades regionais. Com exceção da região Norte, quatro das cinco macrorregiões do país atingiram as metas relativas a abastecimento de água. As regiões Sudeste e Sul apresentaram destaque nos indicadores de cobertura de água, com um nível acima dos $95 \%$ da população urbana.

\footnotetext{
${ }^{14}$ É importante destacar que o quesito rede geral com canalização interna refere-se à canalização de água dentro do município ligada a uma rede geral. Quando se considera rede geral sem canalização interna, o domicílio possui canalização de água ligada a uma rede geral, sem possuir distribuição interna. O critério poço ou nascente com canalização interna refere-se aos municípios que tem canalização de água dentro do domicílio ligada a poço ou nascente. Ainda considerando esse critério, a diferença para o sem canalização interna, diz respeito aos municípios que tem canalização de água por poço ou nascente, mas não para seu interior. Outro tipo de abastecimento ocorre quando o domicílio for atendido por fonte pública, poço ou bica, localizada fora do município.

${ }^{15}$ A meta número 10 , do objetivo do milênio número sete, destaca que se deve reduzir à metade a população total de 1990 sem acesso aos serviços de saneamento básico até 2015.
} 
Existem também grandes diferenças no acesso aos serviços de água entre os habitantes das áreas urbanas e rurais, pois a água de rede geral está disponível para menos de $28 \%$ dos moradores do campo.

Tabela 1.3 - Percentual de moradores em domicílios particulares permanentes com abastecimento de água, por tipo de abastecimento e situação do domicílio Grandes Regiões, 1992 e 2007

\begin{tabular}{|c|c|c|c|c|c|c|c|}
\hline \multicolumn{8}{|c|}{ ÁREA URBANA } \\
\hline \multirow[b]{2}{*}{ Ano } & \multirow[b]{2}{*}{ Região } & \multicolumn{2}{|c|}{ Rede geral } & \multicolumn{2}{|c|}{ Poço ou Nascente } & \multirow[b]{2}{*}{$\begin{array}{c}\text { Outro tipo ou } \\
\text { sem declaração }\end{array}$} & \multirow[b]{2}{*}{ Tota } \\
\hline & & $\begin{array}{c}\text { Com } \\
\text { canalização } \\
\text { interna }\end{array}$ & $\begin{array}{c}\text { Sem } \\
\text { canalização } \\
\text { interna }\end{array}$ & $\begin{array}{c}\text { Com } \\
\text { canalização } \\
\text { interna }\end{array}$ & $\begin{array}{c}\text { Sem } \\
\text { canalização } \\
\text { interna }\end{array}$ & & \\
\hline \multirow{6}{*}{1992} & Norte & 56,05 & 13,83 & 6,18 & 15,87 & 8,07 & 100 \\
\hline & Nordeste & 70,65 & 9,98 & 1,73 & 5,23 & 12,41 & 100 \\
\hline & Sudeste & 90,66 & 3,55 & 3,20 & 1,65 & 0,94 & 100 \\
\hline & Sul & 87,19 & 3,73 & 5,98 & 1,98 & 1,13 & 100 \\
\hline & Centro Oeste & 72,10 & 8,78 & 10,25 & 8,11 & 0,76 & 100 \\
\hline & Brasil & 82,31 & 6,00 & 3,91 & 3,76 & 4,02 & 100 \\
\hline \multirow{6}{*}{2007} & Norte & 63,22 & 4,38 & 21,19 & 8,65 & 2,56 & 100 \\
\hline & Nordeste & 88,12 & 3,29 & 3,96 & 1,99 & 2,63 & 100 \\
\hline & Sudeste & 96,37 & 0,27 & 2,77 & 0,33 & 0,26 & 100 \\
\hline & Sul & 95,01 & 0,34 & 4,03 & 0,41 & 0,21 & 100 \\
\hline & Centro Oeste & 89,82 & 0,58 & 8,15 & 1,21 & 0,25 & 100 \\
\hline & Brasil & 91,28 & 1,32 & 5,00 & 1,42 & 0,99 & 100 \\
\hline
\end{tabular}

Fonte: Ipea, com base nos micro dados da Pnad/IBGE, 1992 e 2007

ÁREA RURAL

\begin{tabular}{|c|c|c|c|c|c|c|c|}
\hline \multirow[b]{2}{*}{ Ano } & \multirow[b]{2}{*}{ Região } & \multicolumn{2}{|c|}{ Rede geral } & \multicolumn{2}{|c|}{ Poço ou Nascente } & \multirow[b]{2}{*}{$\begin{array}{c}\text { Outro tipo ou } \\
\text { sem declaração }\end{array}$} & \multirow[b]{2}{*}{ Total } \\
\hline & & $\begin{array}{c}\text { Com } \\
\text { canalização } \\
\text { interna }\end{array}$ & $\begin{array}{c}\text { Sem } \\
\text { canalização } \\
\text { interna }\end{array}$ & $\begin{array}{c}\text { Com } \\
\text { canalização } \\
\text { interna }\end{array}$ & $\begin{array}{c}\text { Sem } \\
\text { canalização } \\
\text { interna }\end{array}$ & & \\
\hline \multirow{6}{*}{1992} & Norte & - & 1,65 & 11,10 & 77,20 & 10,06 & 100 \\
\hline & Nordeste & 8,31 & 4,21 & 2,81 & 43,29 & 41,38 & 100 \\
\hline & Sudeste & 12,85 & 2,92 & 47,88 & 30,42 & 5,93 & 100 \\
\hline & Sul & 8,75 & 1,95 & 61,25 & 24,94 & 3,10 & 100 \\
\hline & CentroOeste & 3,60 & 0,61 & 43,29 & 50,35 & 2,15 & 100 \\
\hline & Brasil & 9,08 & 3,28 & 25,98 & 37,86 & 23,80 & 100 \\
\hline \multirow{6}{*}{2007} & Norte & 12,96 & 5,47 & 27,53 & 45,50 & 8,54 & 100 \\
\hline & Nordeste & 23,38 & 6,66 & 16,44 & 28,85 & 24,67 & 100 \\
\hline & Sudeste & 28,46 & 1,20 & 59,61 & 6,54 & 4,19 & 100 \\
\hline & Sul & 29,94 & 0,43 & 65,36 & 3,54 & 0,73 & 100 \\
\hline & CentroOeste & 15,97 & 1,35 & 68,73 & 12,20 & 1,74 & 100 \\
\hline & Brasil & 23,79 & 4,16 & 36,92 & 21,44 & 13,70 & 100 \\
\hline
\end{tabular}

Fonte: Ipea, com base nos micro dados da Pnad/IBGE, 1992 e 2007 
Com relação aos índices de esgotamento sanitário, destacados na tabela $1.4^{16}$, o aumento de três pontos percentuais na proporção da população urbana com acesso à rede coletora de esgoto registrou o maior aumento ocorrido nos últimos 15 anos. Contudo, tais índices ainda estão longe de serem satisfatórios.

Tabela 1.4 - Percentual de moradores em domicílios particulares permanentes por tipo de esgotamento sanitário e situação do domicílio - Grandes Regiões, 1992 e 2007

ÁREA URBANA

\begin{tabular}{|c|c|c|c|c|c|c|c|c|c|}
\hline \multirow[b]{2}{*}{ Ano } & \multirow[b]{2}{*}{ Região } & \multicolumn{6}{|c|}{ Com Esgotamento Sanitário } & \multirow[b]{2}{*}{$\begin{array}{l}\text { Não } \\
\text { tinham }\end{array}$} & \multirow[b]{2}{*}{ Total } \\
\hline & & $\begin{array}{c}\text { Rede } \\
\text { Coletora }\end{array}$ & $\begin{array}{c}\text { Fossa } \\
\text { Séptica }\end{array}$ & $\begin{array}{c}\text { Fossa } \\
\text { Rudimentar }\end{array}$ & Vala & $\begin{array}{c}\text { Direto para rio, } \\
\text { vala ou mar } \\
\end{array}$ & $\begin{array}{l}\text { Outro } \\
\text { tipo }\end{array}$ & & \\
\hline \multirow{6}{*}{1992} & Norte & 6,31 & 32,09 & 43,88 & 2,49 & 3,43 & 0,19 & 11,62 & 100 \\
\hline & Nordeste & 18,55 & 25,35 & 35,77 & 2,27 & 1,68 & 0,28 & 16,11 & 100 \\
\hline & Sudeste & 72,26 & 10,52 & 9,47 & 2,28 & 3,27 & 0,42 & 1,78 & 100 \\
\hline & Sul & 18,13 & 49,32 & 25,11 & 1,25 & 1,93 & 0,14 & 4,12 & 100 \\
\hline & Centro Oeste & 34,70 & 5,13 & 54,01 & 0,84 & 0,32 & 0,16 & 4,83 & 100 \\
\hline & Brasil & 45,55 & 20,51 & 22,86 & 2,04 & 2,51 & 0,32 & 6,21 & 100 \\
\hline \multirow{6}{*}{2007} & Norte & 11,71 & 52,11 & 27,75 & 2,4 & 2,29 & 0,2 & 3,54 & 100 \\
\hline & Nordeste & 37,81 & 30,55 & 23,44 & 1,85 & 1,55 & 0,14 & 4,66 & 100 \\
\hline & Sudeste & 83,46 & 9,86 & 2,91 & 0,96 & 2,5 & 0,07 & 0,25 & 100 \\
\hline & Sul & 37,98 & 47,03 & 11,62 & 1,49 & 1,22 & 0,1 & 0,57 & 100 \\
\hline & Centro Oeste & 38,61 & 13,68 & 46,36 & 0,12 & 0,39 & 0,04 & 0,8 & 100 \\
\hline & Brasil & 57,39 & 23,57 & 14,11 & 1,29 & 1,92 & 0,1 & 1,62 & 100 \\
\hline
\end{tabular}

Fonte: Ipea, com base nos micro dados da Pnad/IBGE, 1992 e 2007

ÁREA RURAL

\begin{tabular}{|c|c|c|c|c|c|c|c|c|c|}
\hline \multirow[b]{2}{*}{ Ano } & \multirow[b]{2}{*}{ Região } & \multicolumn{6}{|c|}{ Com Esgotamento Sanitário } & \multirow[b]{2}{*}{$\begin{array}{l}\text { Não } \\
\text { tinham }\end{array}$} & \multirow[b]{2}{*}{ Tota } \\
\hline & & $\begin{array}{c}\text { Rede } \\
\text { Coletora }\end{array}$ & $\begin{array}{l}\text { Fossa } \\
\text { Séptica }\end{array}$ & $\begin{array}{c}\text { Fossa } \\
\text { Rudimentar }\end{array}$ & Vala & $\begin{array}{c}\text { Direto para rio, } \\
\text { vala ou mar }\end{array}$ & $\begin{array}{c}\text { Outro } \\
\text { tipo }\end{array}$ & & \\
\hline \multirow{6}{*}{1992} & Norte & - & 0,52 & 21,49 & 0,35 & . & - & 77,65 & 100 \\
\hline & Nordeste & 2,31 & 2,95 & 19,74 & 2,60 & 0,50 & 0,21 & 71,69 & 100 \\
\hline & Sudeste & 7,45 & 6,69 & 43,38 & 3,94 & 14,24 & 1,28 & 23,02 & 100 \\
\hline & Sul & 0,26 & 23,07 & 49,58 & 3,05 & 3,95 & 0,92 & 19,17 & 100 \\
\hline & Centro Oeste & 0,04 & 2,23 & 57,89 & 3,68 & 1,56 & 1,13 & 33,47 & 100 \\
\hline & Brasil & 2,99 & 7,28 & 32,69 & 3,03 & 4,36 & 0,64 & 49,01 & 100 \\
\hline \multirow{6}{*}{2007} & Norte & 1,79 & 19,21 & 51,91 & 3,93 & 0,91 & 0,00 & 22,26 & 100 \\
\hline & Nordeste & 2,23 & 12,26 & 40,96 & 6,78 & 0,85 & 0,42 & 36,50 & 100 \\
\hline & Sudeste & 17,89 & 15,84 & 43,97 & 3,89 & 11,72 & 0,85 & 5,84 & 100 \\
\hline & Sul & 1,86 & 44,94 & 42,53 & 4,78 & 2,28 & 0,21 & 3,40 & 100 \\
\hline & Centro Oeste & 1,49 & 6,37 & 80,60 & 1,62 & 0,37 & 1,04 & 8,53 & 100 \\
\hline & Brasil & 5,30 & 18,40 & 45,32 & 5,26 & 3,28 & 0,46 & 21,99 & 100 \\
\hline
\end{tabular}

Fonte: Ipea, com base nos micro dados da Pnad/IBGE, 1992 e 2007

\footnotetext{
${ }^{16}$ As fossas sépticas são unidades de tratamento primário de esgoto doméstico nas quais são feitas a separação e transformação da matéria sólida contida no esgoto. A fossa rudimentar ocorre quando não há aparelho sanitário no domicílio e o mesmo é servido por fossa rústica (fossa negra, poço ou buraco). A opção "não tinham" diz respeito a domić́lios que não possuem instalação sanitária de qualquer espécie, ou quando seus ocupantes, utilizarem instalação comum a mais de um domicílio.
} 
Logo é possível verificar que nas áreas rurais a cobertura continua ainda muito pequena, o acesso da população de baixa renda e das periferias das grandes cidades é muito baixo quando comparado com o acesso dos mais ricos, e os municípios menores tendem a ter uma maior demanda não atendida, decorrente da existência de economias de densidade (custos declinantes com o adensamento dos usuários) no setor, que tornam o custo maior em localidades que apresentam menores concentrações populacionais.

A questão preocupante é que somente pouco mais da metade da população urbana possui coleta de esgoto (57,39\%). Além disso, apenas um terço do material coletado recebe tratamento e disposição final dos dejetos adequada. Esses números colocam o Brasil ao lado de países como o Congo e bem distante de países como a Alemanha, que trata $99 \%$ de seu esgoto.

Segundo Jouravlev e Terence (2007), a privatização dos serviços de água e esgoto é a alternativa mais viável frente às experiências de outros países latino-americanos para superar os desafios impostos pelo setor. Entretanto, esta deve vir acompanhada de um reajustamento do papel do Estado na gestão da água que exigirá do mesmo novas habilidades e conhecimentos. Esse deverá assumir novas atividades e se retirar de algumas outras para não abandonar sua responsabilidade de regulamentação de tais serviços. Esse projeto implica reestruturação de atribuições ministeriais além de uma ampla reforma quanto à revisão de políticas internas.

Parlatore (2000) também cita uma série de outros argumentos a favor da privatização levando em consideração os problemas característicos das empresas públicas tais como prioridade para produção de água em detrimento da otimização da distribuição (menor eficiência), atuação deficiente na área comercial (falta de cadastro adequado de usuários, de instalações e de estruturas tarifárias eficientes) atendimento também deficiente aos usuários, aumento excessivo do quadro de pessoal e, atraso com relação às oportunidades de modernização gerencial e tecnológica contribuindo para a elevação dos custos operacionais, descontinuidade administrativa associada à gestão não-profissional, fraco abastecimento de redes e sistemas de tratamento de esgoto, gerando problemas de saúde pública e de poluição dos recursos hídricos. Para o autor, os obstáculos que existem no caminho para a eliminação do déficit dos serviços de saneamento é a principal justificativa a favor da privatização (PARLATORE, 2000, p.291).

Contudo, um fato que chama atenção é que, apesar das dificuldades em relação a alavancagem de recursos para novos investimentos no setor, pouco se avançou no processo de 
privatização. Isto pode ser decorrência de uma intensa politização relacionada com seu caráter fortemente social, que gera a chamada ingerência política e outras dificuldades tais como empreguismo e clientelismo.

Mas, um fator impeditivo mais preocupante que dificulta os investimentos privados refere-se, segundo Toneto e Saiani (2006), às características do déficit de acesso no setor: concentrado nas regiões mais pobres, na zona rural, nos municípios de menor porte, naqueles que apresentam menor taxa de urbanização e menor renda per capita e nos domicílios de baixa renda. Tais características implicam maiores custos de investimento para os prestadores privados e refletem também maiores riscos.

Outro fator que limita o avanço da iniciativa privada decorre da ausência de diretrizes que definam as ações de operação dos agentes: garantia de minimização de riscos aos emprestadores, estabelecimento de um aparato institucional que viabilize transparência de contas, estabilidade do fluxo de caixa, sistema de seguros, garantia de cumprimento dos contratos e um sistema judiciário eficiente. Os anos anteriores à lei federal de Saneamento indicavam a falta no setor de um conjunto de medidas que fornecesse o aparato institucional necessário para seu desenvolvimento.

De acordo com a avaliação da Associação Brasileira de Infra-Estrutura e Indústria de Base (Abdib) o setor de saneamento deve perseguir alguns objetivos fundamentais: atentar para a importância da participação do setor privado, resgatar a eficiência da gestão na grande maioria das concessionárias públicas, preocupar-se com as agências reguladoras e desenvolver novos modelos de estruturação financeira e segurança do capital investido.

Dados do estudo Valor Econômico Setorial de Saneamento (2008) e Abcon (2008), revelam que, em dez anos, existe a possibilidade de o setor privado atender aproximadamente 45 milhões de pessoas, ou seja, elevar o montante de investimentos de R \$1 bilhão para R\$3 bilhões até 2017.

Contudo, a grande importância de sanar as empresas estaduais de saneamento encontra-se no fato de que estas respondem, atualmente, por mais de $70 \%$ da cobertura dos serviços de água e esgoto da população brasileira e captam (quando apresentam as condições administrativas necessárias) a maior parte de recursos destinados ao setor de saneamento. Nesse caso, é necessário um modelo de gestão adequado que permita a sustentabilidade econômico-financeira de tais empresas e que promova a melhoria da qualidade dos serviços prestados. 


\section{Capítulo 2. NOVO MARCO REGULATÓRIO E PARCERIA PÚBLICO-PRIVADA.}

Há muito tempo se esperava um marco regulatório que instituísse as diretrizes nacionais das políticas públicas para o setor de saneamento básico. A maior parte dos estudos nessa área indica a necessidade de regulação, sob todos os seus aspectos, como uma condição indispensável para que os objetivos de universalização possam de fato se concretizar. A nova lei federal de 05 de janeiro de 2007, número 11.445, supriu essa lacuna institucional, restando apenas fazer valer sua aplicação para todos os entes da federação, sociedade e demais atores envolvidos na busca pela superação dos desafios do setor.

\section{1) A Lei federal do saneamento: $n^{0} \mathbf{1 1 . 4 4 5}$ de janeiro de 2007.}

A nova lei federal número 11.445, de janeiro de 2007, estabelece saneamento básico como o setor que contempla os serviços de abastecimento de água, esgotamento sanitário, limpeza urbana e manejo de resíduos sólidos, drenagem e manejo de águas pluviais. A mesma estabelece a obrigatoriedade de elaboração de um Plano de Saneamento Básico, cujo agente formulador de tal plano é o titular do serviço, que são os municípios, na maior parte dos $\operatorname{casos}^{17}$. Além disso, uma meta fundamental estabelecida nos dispositivos da lei é a universalização de serviços a preços módicos, partindo da eficiência como princípio fundamental.

Os municípios, sozinhos ou reunidos em consórcios públicos, podem instituir fundos para custear as metas de universalização. As receitas obtidas da prestação dos mesmos podem fazer parte desse fundo, de acordo com o estabelecido no Plano de Saneamento.

O plano pode ser específico para cada tipo de serviço, mas deve abranger o diagnóstico da situação no local onde haverá prestação do mesmo, estabelecer objetivos e metas de curto, médio e longo prazo e programas, projetos e ações necessárias para atingir tais metas. Além disso, é necessário também ações para emergências e contingências e mecanismos para a avaliação da eficiência e eficácia das ações programadas bem como articulação com as políticas de desenvolvimento urbano e regional, de habitação, de combate

\footnotetext{
${ }^{17}$ Existe ainda, em relação à referida lei, indefinição em relação à titularidade dos serviços em regiões metropolitanas, tópico discutido em seção próxima.
} 
à pobreza, de proteção ambiental, de promoção da saúde e outras de relevante interesse social voltadas para a melhoria da qualidade de vida, para as quais o saneamento básico seja fator determinante.

Esses planos de saneamento devem ser compatíveis com as bacias hidrográficas nas quais o titular está inserido e serão revistos periodicamente, em prazo não superior a quatro anos. Deve ser assegurada também ampla divulgação dos planos, inclusive através de audiências ou consultas públicas.

Exceto quando regional tal plano deve considerar integralmente o território do ente federado (por exemplo, município) que o elaborou. A entidade reguladora tem a função de verificar o cumprimento dos planos de saneamento executados pelos prestadores.

O controle social dos serviços públicos de saneamento se dará através de órgãos colegiados de caráter consultivo, assegurada a representação dos titulares dos serviços dos órgãos governamentais relacionados ao setor, dos prestadores de serviços públicos, dos usuários e de entidades técnicas, organizações da sociedade civil e de defesa do consumidor relacionadas ao setor de saneamento básico.

A União atuará na execução de planos regionais de saneamento quando esses fizerem parte de regiões integradas de desenvolvimento econômico ou quando tiverem fazendo parte da prestação do serviço público um órgão ou entidade federal.

A Lei dedica o capítulo $\mathrm{V}$ à regulação dos serviços públicos e determina que o exercício da função de regulação deva atender aos princípios de independência decisória, transparência, tecnicidade, celeridade e objetividade das decisões. Nesse contexto, no artigo 22, elenca os principais objetivos da regulação:

I) o estabelecimento de padrões e normas para a adequada prestação dos serviços e para a satisfação dos usuários;

II) a garantia do cumprimento das condições e metas estabelecidas;

III) a prevenção e repressão ao abuso do poder econômico, ressalvada a competência dos órgãos integrantes do sistema nacional de defesa da concorrência;

IV) a definição de tarifas que assegurem tanto o equilíbrio econômico e financeiro dos contratos como a modicidade tarifária, mediante mecanismos que induzam a eficiência e eficácia dos serviços e que permitam a apropriação social dos ganhos de produtividade. 
Além disso, atribui competência à entidade reguladora para que edite normas relativas às dimensões técnica, econômica e social de prestação dos serviços. Essas normas abrangerão, pelo menos, os seguintes aspectos (art. 23): padrões e indicadores de qualidade da prestação dos serviços; requisitos operacionais e de manutenção dos sistemas; metas progressivas de expansão e de qualidade dos serviços e os respectivos prazos; regime, estrutura e níveis tarifários, bem como os procedimentos e prazos de sua fixação, reajuste e revisão; medição, faturamento e cobrança de serviços; monitoramento dos custos; avaliação da eficiência e eficácia dos serviços prestados; plano de contas e mecanismos de informação, auditoria e certificação; subsídios tarifários e não tarifários; padrões de atendimento ao público e mecanismos de participação e informação e, por fim, medidas de contingências e de emergências, inclusive racionamento.

Em linhas gerais, é possível verificar que a lei consagra definição ampliada dos serviços de saneamento básico, determina que tais serviços devem ser prestados observando planejamento, regulação e fiscalização definidos pelo titular e preconiza que cada município brasileiro, por meio de plano de saneamento, defina sua estratégia de universalização.

\section{2) A questão da titularidade e as diversas formas de regulação.}

Historicamente, como vimos em seção anterior, os serviços de saneamento básico são de competência do município, prestados pelo estado (dominância estadual herdada da época do Planasa) e financiados com recursos federais. Esta composição federativa heterogênea tem se tornado uma fonte de paralisia ao desenvolvimento do setor, pois constitui uma fonte de conflitos de interesses (MOTTA, 2006).

A principal causa de tais conflitos refere-se à ambigüidade presente na Constituição Federal acerca da atribuição do poder concedente ao ente federal, em relação à execução das funções públicas de interesse comum. A mesma enuncia que os serviços de saneamento básico são de competência do município (art. 30) ${ }^{18}$; porém, também assegura, por lei estadual, que os estados devem garantir os serviços de saneamento em regiões metropolitanas: ao tratar da competência dos Estados, em seu artigo 25, estabelece que “os Estados poderão, mediante lei complementar, instituir regiões metropolitanas, aglomerações urbanas e microrregiões,

\footnotetext{
${ }^{18}$ Artigo 30 - "organizar e prestar, diretamente ou sob regime de concessão ou permissão, os serviços públicos de interesse local, incluído o de transporte coletivo, que tem caráter essencial".
} 
constituídas por agrupamentos de municípios limítrofes, para integrar a organização, o planejamento e a execução de funções públicas de interesse comum”. Logo, em tais regiões, o poder concedente deveria ser estadual.

Stringhini e Marcato (2009) analisam a questão da disputa entre estados e municípios pela titularidade dos serviços em regiões metropolitanas e afirmam que tal disputa representa grande obstáculo para a melhoria dos serviços nos maiores centros urbanos do país.

Atualmente, essa decisão encontra-se em análise no STF (Supremo Tribunal Federal), mas uma solução definitiva a favor de uma ou outra entidade, ainda assim não oferecerá respostas às dúvidas que permeiam a questão da titularidade.

Segundo os autores, o pano de fundo da solução municipalista está pautado na maior ingerência no ritmo de universalização e na qualidade dos serviços, na obtenção de lucros advindos da prestação direta dos serviços ou da cobrança de taxas de outorga dos concessionários dos serviços públicos no caso de uma licitação. Além disso, empresas municipais de centros regionais ou capitais importantes tais como Cuiabá, Porto Alegre e Campinas são favoráveis à municipalização como defesa de sua existência. Por fim, os mesmos afirmam que a titularidade municipal aumenta a possibilidade de que os municípios organizem licitações para outorgar a concessão de serviços públicos a empresas privadas.

Por outro lado, algumas dificuldades que possivelmente seriam encontradas caso a solução municipal fosse instituída são listadas a seguir:

- $\quad$ Risco de desabastecimento: pode ocorrer caso não haja mecanismos efetivos que obriguem os municípios captadores e fornecedores de água a manterem o fornecimento aos demais municípios.

- Endividamento municipal: os municípios ficariam endividados caso tivessem que arcar com os custos da produção e tratamento de esgoto bem maiores que os da distribuição de água e coleta de esgoto.

- Perdas de economias de escala e de escopo: a descentralização levaria a uma duplicidade de infra-estruturas e ao não aproveitamento de ganhos de escala com o compartilhamento de redes.

- Eliminação de subsídios cruzados: os municípios com maior renda per capita não serão mais obrigados a subsidiar a população de municípios com menor renda. 
De acordo com Motta (2006), as empresas estaduais justificam que, se o mecanismo de subsídios não fosse garantido ${ }^{19}$, o sistema vigente poderia entrar em xeque, pois os municípios superavitários absorveriam os recursos que transferem para outros municípios, restando para o sistema estadual os municípios deficitários que, em conjunto, se tornariam um peso orçamentário acima da capacidade dos estados e, portanto, os serviços de saneamento seriam sucateados.

Segundo Stringhini e Marcato (2009), a solução estadual, no STF, parece enfraquecida e com pouca chance de êxito. Contudo, optar pela municipalização também não parece solucionar o impasse, sobretudo porque, do ponto de vista técnico, é impossível ignorar a interdependência na prestação dos serviços de saneamento dos municípios integrantes de regiões metropolitanas. Nesse sentido, o compartilhamento da titularidade obtido por meio de negociação individual entre Estados e Municípios, se apresenta como um caminho intermediário e consensual à polêmica estabelecida (STRINGHINI e MARCATO, 2009, p. 63).

Para o caso de uma das prestações conjuntas de serviços públicos, foi criada uma nova figura jurídica para oficializar esta parceria, os chamados "contratos de programa". Esse contrato estabelece a gestão associada entre os entes da federação: o Município não integrante da região metropolitana firma, em regra, convênio de cooperação ou consórcio público, conforme disposto no art. 241 da Constituição Federal, notadamente a uma companhia estadual de saneamento. Na lei federal de saneamento, foi expressamente vedado que estes contratos possam atribuir competências de regulação dos serviços aos responsáveis diretos por sua prestação ${ }^{20}$.

No caso da gestão compartilhada, de acordo com artigo 25 da Constituição, a partir do momento em que o Estado institui uma região, surge uma obrigação entre Estado e Município: definir a forma de planejamento, execução e fiscalização dos serviços nos Municípios. Essa obrigatoriedade deve ser levada em conta no processo de negociação entre eles.

Como apresentado em seção anterior as externalidades, a configuração de monopólio natural e o fato dos serviços de saneamento serem classificados como bem público exigem a presença de um Estado regulador que possa corrigir tais falhas de mercado a fim de garantir o

\footnotetext{
${ }^{19}$ Segundo o autor, há falta de transparência na declaração desses subsídios, pois não existem dados que permitam analisar sua focalização nos mais pobres. Dessa forma, defende a substituição de subsídios cruzados por subsídios diretos aos mais necessitados, como num programa social (MOTTA, 2006, p.183).

${ }^{20}$ Ao contrário dos contratos de concessão vigentes na década de 70 que delegam à companhia estadual todas as funções relativas aos serviços, entre elas, a de planejamento e de regulação técnica e tarifária.
} 
bem-estar dos consumidores. Caso contrário, os ganhos de monopólio decorrentes da prestação de serviços de saneamento seriam dissipados ou apropriados pelos empresários. Dentre os diversos objetivos da regulação têm-se: fornecer condições para o cumprimento dos contratos, proteger os usuários, garantir a qualidade dos serviços e sua eficiência.

Salgado e Motta (2005) defendem que a necessidade de um marco regulatório não serve apenas para proteger o usuário do serviço de concessão, mas também assegurar a estabilidade das regras de operação de mercado para os concessionários destes direitos. Essa estabilidade significa uma governança regulatória com autonomia, sem ingerência política e que não distinga entre prestação direta ou indireta, pública ou privada.

As características peculiares da indústria de saneamento básico colocam um desafio aos agentes reguladores, devido a sua complexidade e heterogeneidade. O quadro 2.1 abaixo mostra as diversas características físicas e econômicas do setor e as diversas repercussões para o agente regulador:

\section{Quadro 2.1 - Características do setor de saneamento e suas repercussões}

\begin{tabular}{|c|c|c|}
\hline & Características & Repercussões \\
\hline \multirow{5}{*}{ 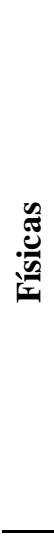 } & $\begin{array}{l}\text { Maioria dos ativos (redes de água e } \\
\text { esgoto) encontra-se enterrada }\end{array}$ & $\begin{array}{l}\text { Difícil determinação do estado de conservação; Custo de manutenção } \\
\text { elevado e complexidade para detecção de vazamentos nas tubulações }\end{array}$ \\
\hline & Mudança lenta no padrão tecnológico & $\begin{array}{l}\text { Poucos ganhos de eficiência mediante avanços tecnológicos; } \\
\text { Ativos com vida útil prolongada }\end{array}$ \\
\hline & $\begin{array}{l}\text { Qualidade dos produtos de complexa } \\
\text { verificação pelo usuário }\end{array}$ & $\begin{array}{l}\text { Necessidade de estrutura adequada para monitoramento da qualidade } \\
\text { de produtos e serviços ofertados pelas concessionárias }\end{array}$ \\
\hline & $\begin{array}{l}\text { Redes integradas em aglomerados } \\
\text { urbanos }\end{array}$ & $\begin{array}{l}\text { Envolvimento de mais de um ente federado na gestão dos serviços; } \\
\text { Expansão da infraestrutura associada ao planejamento urbano }\end{array}$ \\
\hline & $\begin{array}{l}\text { Essencialidade no uso e consumo dos } \\
\text { produtos (água e esgoto) }\end{array}$ & $\begin{array}{l}\text { Atendimento independe da capacidade de pagamento do usuário; } \\
\text { Geração de externalidades positivas e negativas para a saúde pública, } \\
\text { meio ambiente, recursos hídricos,entre outros }\end{array}$ \\
\hline \multirow{6}{*}{ 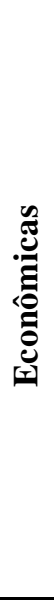 } & Custo fixo elevado & Pouca flexibilidade para etapalização dos investimentos \\
\hline & $\begin{array}{l}\text { Ativos específicos e de longa } \\
\text { maturação }\end{array}$ & $\begin{array}{l}\text { Monopólio natural; Inexistência de usos alternativos e baixo valor de } \\
\text { revenda; Possibilidade remota de saída das concessionárias do mercado } \\
\text { (não-contestável); Pouca atratividade para investimentos }\end{array}$ \\
\hline & Assimetria de informações & $\begin{array}{l}\text { Demais atores do setor dependem da informação técnica e econômico- } \\
\text { financeira disponibilizada pelas concessionárias }\end{array}$ \\
\hline & Demanda inelástica & $\begin{array}{l}\text { Possibilidade de extração de rendas significativas pelo prestador de } \\
\text { serviços (monopólio) }\end{array}$ \\
\hline & Economias de escala & $\begin{array}{l}\text { Viabilidade da prestação dos serviços por uma única empresa } \\
\text { (monopólio) }\end{array}$ \\
\hline & Economias de escopo & $\begin{array}{l}\text { Custos comuns na operação de serviços de água e esgoto e tratamento } \\
\text { de esgotos, tornando mais viável a prestação dos serviços por uma } \\
\text { única empresa (monopólio) }\end{array}$ \\
\hline
\end{tabular}

Fonte: Galvão e Paganini (2009) - Os autores elaboraram a tabela com base em Farina, Azevedo e Picchetti (1997), Jouravlev (2001B), Núcleo de Pesquisas em Informações Urbanas (1995), Seroa da Motta e Moreira (2006), Turolla e Ohira (2006). 
Apesar da regulação dos serviços de saneamento ser fragmentada, a nova lei federal, ao levar em conta tal cenário, estabeleceu uma forma de regulação específica, por meio da institucionalização da regulação setorial ${ }^{21}$. Ou seja, incentiva a delegação das funções regulatórias para entidades públicas de âmbito regional ou estadual, pois muitas vezes os municípios apresentam dificuldades administrativas e financeiras para arcar com a responsabilidade da regulação setorial. Além disso, a regulação econômica, que exige elevada qualificação do quadro técnico da agência reguladora para análise de processos e reajustes tarifários, pode não ser suprida em nível municipal.

A partir de um dispositivo da lei que estabelece a regulação independente (quando a regulação é custeada com recursos advindos das taxas de regulação), Galvão Junior, Turolla e Paganini (2008) concluíram que, no atual contexto institucional e com taxas de regulação de 1,2 ou $3 \%$, é inviável a regulação de saneamento básico na maioria dos municípios brasileiros, pois essa receita não cobriria todos os seus custos regulatórios.

Nesse sentido, os autores mostram que uma alternativa a esse impasse se dá por outro dispositivo importante que a lei estabelece que é “a regulação de serviços públicos de saneamento básico poderá ser delegada pelos titulares a qualquer entidade reguladora constituída dentro dos limites do respectivo Estado, explicitando, no ato de delegação da regulação, a forma de atuação e a abrangência das atividades a serem desempenhadas pelas partes envolvidas". Nesse sentido, têm-se duas alternativas de delegação da regulação: a uma agência estadual ou a um consórcio.

No primeiro caso, a delegação a uma agência estadual pode ocorrer basicamente de acordo com dois modelos institucionais. No primeiro modelo, o município delega parcialmente as atribuições regulatórias à agência estadual, essa atividade é chamada de regulação compartilhada. A limitação desse modelo está no fato de que a eficácia do mesmo é diretamente proporcional à capacidade do município exercer as atribuições dispostas nos instrumentos de delegação. Logo, esses municípios devem possuir estrutura administrativa suficiente para o exercício de atividades regulatórias.

No segundo modelo institucional, o município delega integralmente a regulação à agência reguladora estadual. Nesse caso, o município participa das decisões da agência por meio de representantes eleitos do conjunto dos municípios delegatórios e da própria sociedade. A questão que se coloca, nesse modelo, é saber se o município se sente devidamente representado em um Conselho estadual e de que forma ocorre a articulação entre os municípios e seus

\footnotetext{
${ }^{21} \mathrm{O}$ poder concedente, dono da titularidade, deve ser o responsável pela regulação, mas pode também delegar a outro ente público.
} 
representantes. Já o estabelecimento de consórcios é baseado na agregação entre os municípios como forma de gerar soluções pontualmente eficientes. O principal risco dos consórcios é de que as agregações entre municípios sejam definidas com base em dimensões políticas e conjunturais (GALVÃO JUNIOR; TUROLLA; PAGANINI, 2008).

Essas alternativas, segundo Galvão e Paganini (2009), podem viabilizar a regulação em virtude da economicidade que a agregação de várias concessões proporciona à função reguladora. Além disso, os formatos apresentados não são rígidos e admitem combinações entre diferentes formas de regulação, a exemplo de contrato com presença de agência reguladora. Assim, essas alternativas permitem que, mesmo sem capacidade para regular, titulares dos serviços compartilhem ou deleguem a regulação a outros entes públicos, proporcionando efetividade à atividade (GALVÃO e PAGANINI, 2009).

Segue abaixo tabela 2.1 que resume as principais orientações do novo marco regulatório do setor:

Tabela 2.1 - Resumo dos dispositivos do novo marco regulatório

\begin{tabular}{ll}
\hline \multicolumn{1}{c}{ Gestão } & \multicolumn{1}{c}{ Serviços públicos de saneamento básico } \\
\hline Planejamento & Indelegável, passível de execução por titulares consorciados. \\
\hline \multicolumn{2}{l}{$\begin{array}{l}\text { Regulegável pelo titular ou titulares consorciados a órgão ou ente público, exceto no que diz } \\
\text { respeito à matéria de competência da legislação do titular. Não é conveniente separar em entes } \\
\text { diferentes a execução das tarefas de regulação e fiscalização. }\end{array}$} \\
\hline $\begin{array}{l}\text { Prestação } \\
\text { ente público (leis } 8.987,11.079 \text { ou 11.107). }\end{array}$ \\
\hline Controle Social & Indelegável. \\
\hline Fonte: Ministério das Cidades (2008).
\end{tabular}

Dessa forma, a consolidação deste novo ciclo institucional no saneamento básico brasileiro dependerá da sustentabilidade do padrão de financiamento e do desenho e implementação de um conjunto de ações articuladas entre as várias esferas de governo, sociedade e iniciativa privada.

\section{3) A parceria público-privada (PPP).}

Segundo Giambiagi e Além (2000), a década de 70 caracterizou-se por um período marcado por déficit público elevado, níveis de inflação acima do desejável e expansionismo estatal. Essa realidade foi mudando ao longo do tempo e, os anos 90, foram caracterizados 
pela combinação de: políticas agressivas de combate ao déficit público, redução significativa das taxas de inflação e restrições à participação direta do Estado na economia. Contudo, tal como antes, pela demanda da economia, a necessidade de realização de certos investimentos, cujas características eram as altas exigências de capital, longo prazo de maturação e risco elevado, persistia.

Dado que as empresas estatais não podiam mais executar a construção de grandes projetos, uma vez que estavam submetidas a restrições fiscais e havia uma crescente exigência de estabilidade macroeconômica, uma alternativa viável era a parceria entre o setor público e privado associada à combinação de esforços em favor de objetivos compartilhados.

A oferta de concessões de serviços públicos no Brasil é estabelecida pela Constituição Federal (CF) regime de concessão ou permissão, sempre através de licitação, a prestação de se no artigo 175: “incumbe ao poder público, na forma de lei, diretamente ou sob rviços públicos".

A partir da Lei das Concessões (1995) e da Lei das Parcerias Público-Privadas (2004) passam a existir quatro modalidades de contratos de concessão no Brasil:

- concessão comum ou tradicional, calcada em receitas auto-suficientes e sem contrapartida do Estado (lei 8.987/95);

- concessão comum ou tradicional com contrapartida do Estado, complementar à receita;

- concessão patrocinada com contrapartida do Estado, receita própria insuficiente;

- concessão administrativa sem outra receita que não a do Estado ${ }^{22}$.

Existem ainda as parcerias com o setor privado para projetos que apresentam retorno econômico negativo, mas interesse social positivo. Esses projetos também podem ser firmados mediante concessões administrativas, no âmbito da Lei das PPP, ou via contrato estabelecido pela Lei de Licitações (1993). Contudo, essa lei abrange projetos que envolvam a execução de obras e/ou a prestação de serviços enquadrados num prazo limitado a cinco anos, ou seja, exclui projetos que apresentam longo prazo de maturação. O gráfico 2.1 abaixo apresenta os diversos tipos de contratos que determinam diferentes distribuições de responsabilidade e de riscos entre o setor público e o concessionário privado:

\footnotetext{
${ }^{22}$ Alguns Estados criaram sua própria legislação de PPP, por exemplo, o Estado de São Paulo, onde as parcerias público-privadas são disciplinadas pela Lei Estadual 11.688 de 2004, que criou a Unidade de PPP vinculada à Secretaria Estadual de Economia e Planejamento (Consórcio Inecon/FGV, PSP, 2008).
} 


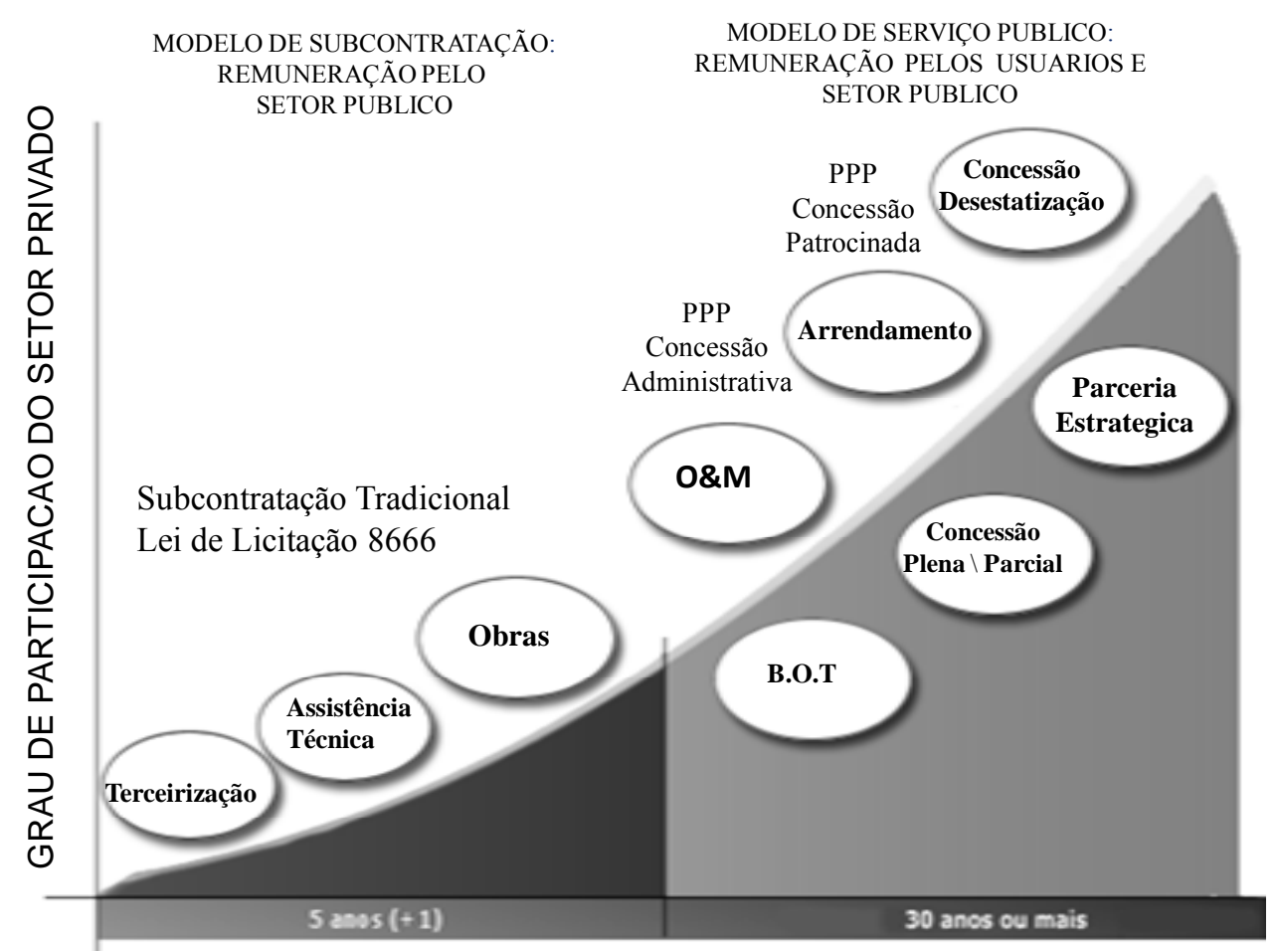

Fonte: ABCON (2008).

Gráfico 2.1 - Contratos de Parceria Público-privada

O Relatório Inecon/FGV (2008), estudo sobre a Participação do Setor Privado (PSP), especifica cada contrato representado no gráfico acima, da seguinte maneira:

- Terceirização, obras e assistência técnica: São usados em atividades complementares, correspondem a um menor envolvimento do setor privado, não exige elevados investimentos iniciais e lhe proporciona um menor risco.

- Arrendamento: O setor público aluga os ativos para o operador privado, que é remunerado pela cobrança de tarifa aos usuários. Nesse caso, o operador privado assume diversos riscos da operação

- B.O.T (Build-Operate-Transfer): Representa o mecanismo clássico de concessão para exploração de um serviço: a iniciativa privada constrói investimentos em nova infraestrutura e opera por determinado período de tempo, no final do qual, os ativos retornam às mãos do Estado.

- Concessão: No Brasil, a Lei 8.987 de 13/02/95, chamada Lei das Concessões, estabelece normas para a participação privada nos projetos de infra-estrutura e na prestação de serviços de utilidade pública. De maneira mais ampla, a Lei 11.079 oferece categorias mais amplas de concessão, especialmente as que envolvem parcela 
complementar oferecida pelo setor público, no caso em que a atratividade ao setor privado é relativamente baixa.

O aumento das experiências de PPP (Parcerias Público-Privadas) é uma realidade no setor e, embora apresente um avanço modesto, contribui para aumentar a participação privada no mesmo e atuar na melhoria e na gestão dos serviços de água e esgoto.

A assinatura do contrato de PPP entre a Sabesp e a Cab ambiental, para construção e operação da estação de tratamento de água de Taiaçupeba, na Grande São Paulo, representou um avanço da participação da iniciativa privada, associada ao gestor público, no setor. $\mathrm{O}$ contrato, de maior porte, firmado em janeiro de 2007, foi estabelecido entre a Embasa e as empresas Odebrecht e Eco Enob, para a construção e operação de moderno emissário submarino em Salvador. Outros contratos do gênero, mas em menor escala, foram assinados no período com as administrações municipais de Tucumã (PA), Mirassol e Guaratinguetá (SP), Aguiarnópolis, Carrasco, Rio do Sono e São Sebastião (TO).

O modelo de concessão, para obter sucesso, depende da estrutura tarifária estabelecida em contrato e do marco regulatório no qual o mesmo se realiza. Segundo o modelo tradicional, as empresas devem cobrar uma tarifa suficiente para remunerar os custos da empresa, cujo valor é baseado numa taxa de retorno estabelecida anteriormente. A desvantagem desse método é que desestimula a busca da eficiência e a redução dos custos, pois a taxa de retorno, uma vez estabelecida, não afeta a remuneração do empresário.

A principal alternativa a esse método é o de price cap (preço máximo) ${ }^{23}$, que define uma tarifa máxima por um determinado período e permite que o concessionário obtenha os ganhos de produtividade alcançados nesse período. A vantagem desse método consiste no estímulo que ele traz para a eficiência da empresa. No entanto, só funciona adequadamente se houver uma fiscalização no que diz respeito à qualidade dos serviços, uma vez que esta pode ser sacrificada, com o objetivo de reduzir custos.

Considerando que as dificuldades relativas ao processo de regulação fossem resolvidas de imediato com a nova lei, existem algumas preocupações que devem ser destacadas no contexto da privatização dos serviços de saneamento. A primeira delas é com o objetivo de se perseguirem metas de universalização, pois o setor de saneamento não pode admitir que existam cidadãos excluídos dos direitos de cobertura, uma vez que lida com um bem essencial ao desenvolvimento humano e não com um bem individualizado. Nesse contexto, o setor privado falha no cumprimento desse objetivo uma vez que não lhe interessa operar em regiões

\footnotetext{
${ }^{23}$ O mecanismo de price cap foi estabelecido na Inglaterra, num contexto de reformas e privatizações. Em 1989 e 1990, foi introduzido no setor de abastecimento de água.
} 
de baixa renda, pois a população menos favorecida é mais sensível a qualquer aumento de tarifa e, geralmente, são regiões que necessitam de maiores níveis de investimento e podem registrar maiores índices de inadimplência.

De acordo com Fernandois (2009), a vantagem das empresas privadas em imporem tarifas que atendam a seus interesses, sem que estejam submetidas a pressões externas que as afetem, não garante a obtenção de tarifa justa. Ao contrário, tais empresas determinam um nível de tarifa acima daquele que remunera adequadamente capital e mão-de-obra, incompatível com a prestação eficiente dos serviços.

Outra ressalva que deve ser feita é em relação ao trade-off custo/qualidade que o setor privado enfrenta quando detém a concessão para operar algum serviço público. Em alguns casos, os agentes privados optam por sacrificar a qualidade do serviço público para reduzir custos e obter maiores lucros. A mesma autora ressalta esse argumento ao afirmar que a motivação pela operação a custo mínimo pode ser tão forte nas empresas privadas que as façam descuidar de aspectos da qualidade dos serviços no longo prazo, em benefício da maximização dos benefícios de curto prazo.

Essa é a tese defendida por Cabral, Lazzarini e Azevedo (2007), ao estudar os agentes públicos e privados de prisões do Estado do Paraná, observados a partir de 2001 a 2006. Segundo eles, nesse setor, os agentes privados recebem uma remuneração fixa pelas atividades exercidas, que os induzem a reduzir custos via deterioração da qualidade e, assim, podem lucrar mais. Os autores propõem um modelo híbrido de gestão público-privada de forma que um supervisor do Estado tenha um incentivo implícito para controlar eficazmente o agente privado, garantir a qualidade dos serviços e ainda preservar incentivos para redução de custos.

Esse modelo é desenvolvido para o sistema de prisões brasileiras, mas, de acordo com os autores, seus resultados deveriam ser estendidos para outros serviços de utilidade pública tais como abastecimento de água, serviços de esgoto e portos.

Seus argumentos baseiam-se no fato de que, apesar do setor privado ter uma atitude mais eficiente para reduzir custos (mesmo que isso comprometa a qualidade dos serviços), por outro lado, estes agentes empregam contratos de trabalho que permitem a introdução de altos incentivos para estimular a produtividade dos funcionários e conseguem realizar uma troca mais rápida de trabalhadores quando estes não atingem determinadas metas. Já na gestão pública a substituição de trabalhadores não é automática devido a vários procedimentos burocráticos que envolvem tanto processos de contratação quanto limitações fiscais. 
Dessa forma, a ação isolada de cada um desses extremos não é viável. O maior poder de incentivo associado à governança privada é, ao mesmo tempo, um benefício e um custo para a privatização dos serviços públicos, pois o mesmo incentivo para reduzir custos leva a uma deterioração da qualidade e, até mesmo, a negligenciar metas de universalização que devem se perseguidas pelo setor.

Para resolver esse impasse, os autores sugerem que poderia ser estabelecido um contrato completo entre os agentes envolvidos com todas as normas a serem seguidas. Contudo, se a dimensão de desempenho estabelecida nesse contrato fosse fácil de ser medida o problema de governança dos serviços públicos seria trivial (por exemplo, é difícil contratualmente especificar um nível adequado de "tratamento" aos reclusos em termos do uso ideal de força, quantidades de serviços médicos, alimentares e assim por diante). Nesse caso, qualquer observação de desempenho abaixo da meta inicial poderia significar a aplicação de sanções, multas, suspensão de pagamentos, divisão do contrato com outro agente privado, entre outros. Portanto, por essa dificuldade de medida, o contrato entre governo e operadores privados provavelmente será incompleto.

Com base nessa hipótese de contrato incompleto, os resultados empíricos mostram que a nomeação de um supervisor público dentro da prisão ajuda a assegurar níveis satisfatórios de qualidade. Nesse caso, a separação entre operação e supervisão é importante. Com a presença do supervisor, o modo híbrido de gestão exibe baixos custos e também evita o tradeoff entre custo e qualidade.

Assim como ocorre no sistema penitenciário, os autores afirmam que esse resultado deve se estender para outros setores de utilidade pública. Dessa forma, podemos concluir que é imprescindível que exista uma fiscalização (atividades ligadas à regulação e controle) do governo federal no oferecimento dos serviços de saneamento básico pelos agentes privados.

Fernandois (2009) aponta que as desvantagens apresentadas por uma empresa privada prestadora de serviços de saneamento básico podem ser superadas com o desenvolvimento de um sistema de tarifas que seja de fácil aplicação e que faça valer as determinações da autoridade regulatória. Além disso, essa deve exercer um controle estrito sobre a qualidade das prestações de serviços com o estabelecimento de sanções (que podem chegar ao cancelamento da concessão) caso as normas não sejam cumpridas. Se isto ocorrer, as empresas privadas se verão obrigadas a operar a um custo mínimo, com serviços de qualidade, se desejam obter rentabilidade. 
Entretanto, sem desconsiderar a extrema importância de um sistema regulatório eficaz, a questão da universalização dos serviços não pressupõe uma escolha única entre prestador de serviço público ou privado. Os ganhos que podem ser auferidos de parcerias entre esses dois tipos de natureza jurídica, vêm ganhando importância no setor ${ }^{24}$. Dessa forma, os modos híbridos de governança, que representam uma saída para atrair novos investimentos, é uma alternativa possível para o modelo atual que, não comporta, pelas justificativas apresentadas, uma predominância exclusiva do setor privado nem tão pouco um domínio absoluto do poder público.

\section{4) A estrutura de oferta do setor.}

A análise da estrutura de oferta do setor de saneamento básico fornece subsídios para a compreensão do atual quadro de provisão recente no país: tipos de provedores, seus respectivos graus de abrangência, organização institucional e outras características. Essa estrutura será desenhada a partir das informações do SNIS, Sistema Nacional de Informações sobre Saneamento, o maior banco de dados do setor que reúne informações de 1995 a 2007. Foi criado no âmbito do Programa de Modernização do Setor de Saneamento (PMSS) pelo Ministério das Cidades e Secretaria Nacional de Saneamento Ambiental (SNSA). O banco apresenta dados de serviços relativos à água e esgoto e resíduos sólidos urbanos. Nesse estudo, irá se utilizar somente informações e indicadores do primeiro componente.

O SNIS seleciona uma amostra de prestadores de serviços incluindo, desde a sua criação, todas as companhias estaduais de saneamento, todos os prestadores de serviços de âmbito microrregional e um conjunto crescente de prestadores locais (municipais) de serviços de saneamento. Em seus treze anos de existência, o SNIS ampliou de 54 para 605 a quantidade de prestadores de serviços publicados, enquanto que a amostra para dados desagregados ao nível municipal alcançou, em 2007, 4.547 municípios, considerando todos os tipos de prestadores.

Portanto, é um valioso instrumento de auxílio à formulação de políticas públicas, pois conta com uma amostra bastante significativa do universo dos prestadores, ainda que apresente uma série de imperfeições tais como erros de preenchimento por parte dos

\footnotetext{
${ }^{24}$ Aprovação em 2004 da lei das parcerias público-privadas.
} 
informantes, desconhecimento e falta de compreensão de algumas questões, também pelo fato de ser auto-declaratório e de superestimar os índices de atendimento.

É importante ressaltar que a partir da lei federal número 11.445/2007 o SNIS foi transformado em SNISA (Sistema Nacional de Informações em Saneamento Básico) e, apesar de todas as informações e indicadores que já contém, ainda necessita de uma expansão para novos blocos de dados a fim de aperfeiçoar o monitoramento das políticas públicas, prover instrumentos que facilitem a regulamentação do setor e divulgação dos dados que indiquem sua evolução e desafios a serem superados.

A base geográfica de dados do SNIS é o município. Os prestadores de serviços de saneamento que atendem a um único município são chamados de locais. Existem ainda os prestadores que atendem a mais de um município ${ }^{25}$, com sistema(s) isolado(s) ou integrado(s), normalmente adjacentes e agrupados em uma pequena quantidade, que são chamados microrregionais. E, por fim, os que atendem a vários municípios são classificados como regionais, categoria que compreende as companhias estaduais de saneamento. A tabela 2.2 abaixo apresenta a distribuição desses provedores por região do país;

Tabela 2.2 - Quantidade dos tipos de prestadores por região

\begin{tabular}{lllll}
\hline Regiões & $\begin{array}{l}\text { Prestador } \\
\text { Regional }\end{array}$ & $\begin{array}{l}\text { Prestador } \\
\text { Microrregional }\end{array}$ & $\begin{array}{l}\text { Prestador } \\
\text { Local }\end{array}$ & Total \\
\hline Norte & 7 & - & 38 & 45 \\
Nordeste & 9 & 1 & 98 & 108 \\
Sudeste & 4 & 4 & 228 & 236 \\
Sul & 3 & 2 & 78 & 83 \\
CentroOeste & 3 & 1 & 129 & 133 \\
Total & $\mathbf{2 6}$ & $\mathbf{8}$ & $\mathbf{5 7 1}$ & $\mathbf{6 0 5}$ \\
\hline \multicolumn{7}{l}{ Fonte: Elaboração própria da autora baseada em SNIS (2007). }
\end{tabular}

Além dessa tipologia, que leva em conta a abrangência geográfica da atuação de cada prestador, o SNIS também adota o critério de natureza jurídica para diferenciar os prestadores do ponto de vista da formalidade legal e administrativa à qual estão submetidos. Com o objetivo de sistematizar a organização dos dados, o SNIS agrupa dois tipos de categorias: entidades de direito público e entidades de direito privado. São entidades de direito público os serviços municipais operados por órgão da administração direta centralizada (secretarias, departamentos ou outros órgãos municipais) ou por órgão também da administração direta,

\footnotetext{
${ }^{25}$ Geralmente por meio de consórcios intermunicipais: associação de um ou mais municípios para obter ganhos de escala em suas operações.
} 
mas descentralizada, organizado na modalidade autarquias. São de direito privado as empresas públicas, as sociedades de economia mista e as empresas privadas.

É importante destacar a diferença entre natureza jurídica direito privado e a propriedade e administração privada das entidades. Todas as companhias estaduais de saneamento e os serviços municipais constituídos sob a forma de empresas são entidades de direito privado, ainda que administradas pelo poder público. Logo, de acordo com esse critério de natureza jurídica, os prestadores se enquadram em seis categorias listadas a seguir:

1) Administração pública direta centralizada: são as secretarias, departamentos e outros órgãos da administração pública. É a área da administração pública vinculada ao poder executivo federal, estadual ou municipal. Pertencem a essa categoria, no plano federal, a Presidência da República, os Ministérios e os órgãos a eles vinculados diretamente.

2) Autarquia: entidade com personalidade jurídica de direito público, criada por lei específica, com patrimônio próprio, atribuições públicas específicas e autonomia administrativa, sob controle estadual ou municipal. Nos termos do artigo $150, \S 2^{\circ}$ da Constituição Federal, em se tratando das autarquias, não há incidência de tributos, vez que as mesmas gozam de imunidade tributária. As autarquias fazem parte da administração pública indireta e são responsáveis pela execução de serviços instituídos para limitar a expansão da administração direta ou aperfeiçoar sua ação executiva no desempenho de atividades de interesse público, de cunho econômico ou social.

3) Empresa pública: entidade com personalidade jurídica de direito privado, mas com capital exclusivamente público, ou seja, participação única do poder público no seu capital e direção. O objetivo da empresa pública também deve ser o lucro, ainda que esse seja utilizado em benefício da comunidade.

4) Sociedade de economia mista com gestão pública: entidade de capital público e privado, mas com maioria pública nas ações com direito a voto e gestão exclusivamente pública. Essa entidade é uma pessoa jurídica de direito privado e não se beneficia de isenções fiscais ou de foro privilegiado. Toda sociedade de economia mista é uma sociedade anônima, seus funcionários são regidos pela CLT e não são servidores públicos.

5) Sociedade de economia mista com gestão privada: entidade de capital público e privado, porém com maior participação dos sócios privados na gestão dos negócios da 
empresa. A única diferença com a sociedade de economia mista com gestão pública é que, nesse caso, mais da metade das ações com direito a voto devem pertencer a agentes privados.

6) Empresa privada: entidade que possui capital predominantemente ou integralmente privado, administrada exclusivamente por particulares.

A distribuição dos três tipos de prestadores segundo sua natureza jurídica está sumarizada na tabela 2.3 apresentada abaixo.

Tabela 2.3 - Agrupamento dos prestadores segundo abrangência regional e natureza jurídica

\begin{tabular}{|c|c|c|c|c|}
\hline Natureza Jurídica & $\begin{array}{c}\text { Prestador } \\
\text { Regional }\end{array}$ & $\begin{array}{c}\text { Prestador } \\
\text { Microrregional }\end{array}$ & $\begin{array}{l}\text { Prestador } \\
\text { Local }\end{array}$ & Total \\
\hline Administração Pública Direta & 0 & 0 & 193 & 193 \\
\hline Autarquia & 1 & 5 & 320 & 326 \\
\hline Empresa Pública & 0 & 0 & 9 & 9 \\
\hline $\begin{array}{l}\text { Sociedade de Economia Mista com } \\
\text { administração Pública }\end{array}$ & 23 & 0 & 10 & 33 \\
\hline $\begin{array}{l}\text { Sociedade de Economia Mista com } \\
\text { administração Privada }\end{array}$ & 1 & 0 & 0 & 1 \\
\hline Empresa Privada & 1 & 3 & 39 & 43 \\
\hline Total & 26 & 8 & 571 & 605 \\
\hline
\end{tabular}

Além de identificar os tipos de prestadores dentro de cada categoria de natureza jurídica, é interessante quantificar e caracterizar as mudanças entre essas diversas categorias, ocorridas ao longo da série histórica do SNIS, de 1995 a 2007, a fim de verificar algumas possíveis tendências pontuais entre os prestadores, ligadas à formalidade legal e administrativa à qual estão submetidas. A tabela 1.1 do apêndice mostra, para cada município, a mudança de natureza jurídica do prestador local ou regional, o ano em que a mesma ocorreu e qual era a categoria anterior que a empresa se encontrava.

Pela tabela resumo 2.4 é possível constatar que ocorreram mudanças de natureza jurídica do prestador local em 97 municípios durante esse período. O ano que registrou o maior número (trinta e um) de tais mudanças foi 2005 e a região que obteve o maior número de municípios nessas condições foi a Centro-Oeste, com trinta e duas alterações. 
Tabela 2.4 - Número de mudanças entre categorias de natureza jurídica por ano e região

\begin{tabular}{cc}
\hline Ano/Região & $\begin{array}{c}\text { Número de } \\
\text { alterações }\end{array}$ \\
\hline Década 90 & 6 \\
2000 & 9 \\
2001 & 5 \\
2002 & 11 \\
2003 & 1 \\
2004 & 14 \\
2005 & 31 \\
2006 & 18 \\
2007 & 2 \\
Total & $\mathbf{9 7}$ \\
\hline CO & 32 \\
SE & 31 \\
NO & 14 \\
SU & 10 \\
NE & 10 \\
Total & $\mathbf{9 7}$ \\
\hline Fonte: Elaborã̃o própria da
\end{tabular}

Fonte: Elaboração própria da autora.

A mudança que mais se repetiu ao longo dos anos foi de administração pública direta para autarquia cujo número foi de vinte e sete, de acordo com a tabela 2.5. Nesse sentido, a categoria de origem da qual os prestadores mais partiram foi administração pública direta e a que elas mais se direcionaram foi autarquia, conforme descreve a mesma tabela.

Tabela 2.5 - Número de saídas e entradas em cada categoria de natureza jurídica

\begin{tabular}{lcc}
\hline \multicolumn{1}{c}{ Natureza Jurídica } & $\begin{array}{c}\text { Número de saídas da } \\
\text { categoria de Origem }\end{array}$ & $\begin{array}{c}\text { Número de entradas na } \\
\text { categoria de Destino }\end{array}$ \\
\hline Administração Pública Direta & 50 & 23 \\
Autarquia & 21 & 33 \\
Empresa Privada & 10 & 19 \\
Empresa Pública & 6 & 11 \\
Sociedade de Economia Mista com Administração Pública & 8 & 9 \\
Sociedade de Economia Mista com Administração Privada & 2 & 2 \\
Total & $\mathbf{9 7}$ & $\mathbf{9 7}$ \\
\hline
\end{tabular}

Fonte: Elaboração própria da autora.

A análise de tais alterações é importante, pois a estrutura institucional de cada empresa pode afetar seu resultado econômico financeiro e, de forma agregada, pode influenciar nos níveis de eficiência do setor. Por exemplo, muitas empresas consideraram vantajoso migrar 
para autarquia a fim de se tornarem menos onerosas. Por outro lado, a migração para administração pública direta conta com algumas transferências governamentais específicas dessa categoria. Nesse sentido, cabe pesar os prós e contra de tais escolhas.

Alguns grupos, da amostra do SNIS, foram escolhidos para identificar prestadores importantes para o presente estudo: prestadores microrregionais, regionais e locais privados. A tabela 2.6 lista os prestadores microrregionais que são de dois tipos de natureza jurídica: empresa privada e autarquia.

Tabela 2.6 - Prestadores microrregionais segundo natureza jurídica

\begin{tabular}{|c|c|c|c|}
\hline & Prestador Microrregional & Município sede & Estado \\
\hline \multicolumn{4}{|c|}{ EMPRESA PRIVADA } \\
\hline 1 & Concessionária Águas de Juturnaíba S/A (CAJ) & Aracaju & SE \\
\hline 2 & Prolagos S/A - Concessionária de Serviços Públicos de Água e Esgoto (PROLAGOS) & Belém & PA \\
\hline 3 & Serviço de Tratamento de Água e Esgoto (SETAE) & Belo Horizonte & MG \\
\hline \multicolumn{4}{|c|}{ AUTARQUIA } \\
\hline 1 & Serviço Autônomo de Água e Esgoto (SAAE) & Aimorés & MG \\
\hline 2 & Serviço Intermunicipal de Água e Esgoto (SIMAE) & Capinzal & SC \\
\hline 3 & Serviço Autônomo de Água e Esgoto (SAAE) & Itapemirim & ES \\
\hline 4 & Serviço Intermunicipal de Água e Esgoto (SIMAE) & Joaçaba & SC \\
\hline 5 & Serviço Autônomo de Água e Esgoto (SAAE) & São Miguel dos Campos & $\mathrm{AL}$ \\
\hline
\end{tabular}

Fonte: Elaboração própria da autora baseada em SNIS (2007).

A tabela 2.7 identifica os vinte e seis prestadores regionais do setor ${ }^{26}$. Entre eles, vinte e três são sociedades de economia mista com administração pública e os outros três são sociedade de economia mista com administração privada, empresa privada e autarquia.

\footnotetext{
${ }^{26}$ Entre essas empresas, as que têm acesso ao mercado de capitais são a Sanepar (PR), Sabesp (SP), Copasa (MG) e Casan (SC) e entre as locias, a Sanesalto (SP), município de Salto (BM\&F, Bovespa, 2009).
} 
Tabela 2.7 - Prestadores regionais segundo natureza jurídica

\begin{tabular}{|c|c|c|c|}
\hline & Prestador Regional & Município sede & Estado \\
\hline \multicolumn{4}{|c|}{ SOCI EDADE DE ECONOMI A MI STA COM ADMI NI STRAÇÃO PÚBLICA } \\
\hline 1 & Companhia de Saneamento de Sergipe (DESO) & Aracaju & SE \\
\hline 2 & Companhia de Saneamento do Pará (COSANPA) & Belém & PA \\
\hline 3 & Companhia de Saneamento de Minas Gerais (COPASA) & Belo Horizonte & MG \\
\hline 4 & Companhia de Águas e Esgotos de Roraima (CAER) & Boa Vista & $\mathrm{RR}$ \\
\hline 5 & Companhia de Saneamento Ambiental do Distrito Federal (CAESB) & Brasília & DF \\
\hline 6 & Empresa de Saneamento de Mato Grosso do Sul S/A (SANESUL) & Campo Grande & MS \\
\hline 7 & Companhia Catarinense de Águas e Saneamento (CASAN) & Florianópolis & SC \\
\hline 8 & Companhia de Água e Esgoto do Ceará (CAGECE) & Fortaleza & CE \\
\hline 9 & Saneamento de Goiás S/A (SANEAGO) & Goiânia & GO \\
\hline 10 & Companhia de Águas e Esgotos da Paraíba (CAGEPA) & J oão Pessoa & PB \\
\hline 11 & Companhia de Água e Esgoto do Amapá (CAESA) & Macapá & AP \\
\hline 12 & Companhia de Saneamento de Alagoas (CASAL) & Maceió & $\mathrm{AL}$ \\
\hline 13 & Companhia de Saneamento do Amazonas (COSAMA) & Manaus & AM \\
\hline 14 & Companhia de Águas e Esgotos do Rio Grande do Norte (CAERN) & Natal & RN \\
\hline 15 & Companhia Rio-Grandense de Saneamento (CORSAN) & Porto Alegre & RS \\
\hline 16 & Companhia de Águas e Esgotos de Rondônia (CAERD) & Porto Velho & RO \\
\hline 17 & Companhia Pernambucana de Saneamento (CAMPESA) & Recife & PE \\
\hline 18 & Companhia Estadual de Águas e Esgotos (CEDAE) & Rio de J aneiro & RJ \\
\hline 19 & Empresa Baiana de Águas e Saneamento (EMBASA) & Salvador & BA \\
\hline 20 & Companhia de Águas e Esgotos do Maranhão (CAEMA) & São Luís & MA \\
\hline 21 & Companhia de Saneamento Básico do Estado de São Paulo (SABESP) & São Paulo & $\mathrm{SP}$ \\
\hline 22 & Águas e Esgotos do Piauí S/A (AGESPISA) & Teresina & $\mathrm{PI}$ \\
\hline 23 & Companhia Espírito-Santense de Saneamento (CESAN) & Vitória & ES \\
\hline \multicolumn{4}{|c|}{ SOCI EDADE DE ECONOMI A MI STA COM ADMI NI STRAÇÃO PRI VADA } \\
\hline 1 & Companhia de Saneamento do Paraná (SANEPAR) & Curitiba & PR \\
\hline \multicolumn{4}{|c|}{ EMPRESA PRI VADA } \\
\hline 1 & Companhia de Saneamento do Tocantins (SANEATINS) & Palmas & TO \\
\hline \multicolumn{4}{|c|}{ AUTARQUI A } \\
\hline 1 & Departamento Estadual de Água e Saneamento & Rio Branco & $\mathrm{AC}$ \\
\hline
\end{tabular}

Fonte: Elaboração própria da autora baseada em SNIS (2007).

A tabela 2.8 elenca os trinta e nove prestadores privados locais (entidade prestadora se situa no município em que provê o serviço). Os outros prestadores privados, que atendem a mais de um município, regionais ou microrregionais, estão destacados nas tabelas anteriores. 
Tabela 2.8 - Prestadores locais privados

\begin{tabular}{|c|c|c|c|c|c|c|c|}
\hline & Municípios & Estado & Operadora Local & $\begin{array}{l}\text { População } \\
\text { Atendida }\end{array}$ & Modalidade & $\begin{array}{l}\text { Início da } \\
\text { Operação }\end{array}$ & $\begin{array}{c}\text { Prazo } \\
\text { em } \\
\text { anos }\end{array}$ \\
\hline 1 & Alta Floresta & MT & Águas de Alta Floresta & 47.281 & snis & snis & - \\
\hline 2 & $\begin{array}{l}\text { Cachoeiro de } \\
\text { Itapemirim }\end{array}$ & ES & Águas de Cachoeiro S/A - Citágua & 190.808 & plena & $15 / 07 / 1998$ & 37,5 \\
\hline 3 & Campo Grande & MS & Águas Guariroba & 749.942 & plena & $23 / 10 / 2000$ & 30 \\
\hline 4 & Campo Verde & MT & Águas de Campo Verde & 25.533 & plena & $29 / 11 / 2001$ & 30 \\
\hline 5 & $\begin{array}{l}\text { Campos dos } \\
\text { Goytacazes }\end{array}$ & RJ & Águas do Paraíba & 400.000 & plena & $14 / 09 / 1999$ & 30 \\
\hline 6 & Canarana & MT & Companhia Ambiental de Canarana Ltda & 19.329 & - & - & - \\
\hline 7 & Carlinda & MT & Águas de Carlinda & 6.050 & plena & $01 / 03 / 2004$ & 30 \\
\hline 8 & Cláudia & MT & Águas de Claudia & 8.228 & plena & $01 / 08 / 2004$ & 30 \\
\hline 9 & Cólider & MT & Colider Água e Saneamento Ltda & 26.738 & - & . & - \\
\hline 10 & Guapimirim & RJ & Fontes da Serra & 25.788 & plena & $05 / 05 / 2001$ & 30 \\
\hline 11 & Guará & SP & Águas de Guará & 20.300 & plena & $17 / 05 / 2000$ & 25 \\
\hline 12 & $\begin{array}{l}\text { Guarantã do } \\
\text { Norte }\end{array}$ & MT & Águas de Guarantã Ltda. & 23.042 & plena & $02 / 05 / 2001$ & 30 \\
\hline 13 & Itapema & SC & Águas de Itapema & 34.448 & plena & $08 / 07 / 2004$ & 25 \\
\hline 14 & Jangada & MT & Saneamento B. de J angada & 3.539 & plena & $01 / 07 / 2004$ & 30 \\
\hline 15 & Limeira & $\mathrm{SP}$ & Águas de Limeira & 286.975 & plena & 02/06/1995 & 30 \\
\hline 16 & Manaus & AM & Águas do Amazonas & 1.558 .078 & plena & $04 / 07 / 2000$ & 30 \\
\hline 17 & Marcelândia & MT & Águas de Marcelândia & 18.634 & plena & $01 / 09 / 2003$ & 30 \\
\hline 18 & Matupá & MT & Águas de Matupá & 12.470 & plena & $29 / 10 / 2001$ & 30 \\
\hline 19 & Mauá & SP & $\begin{array}{l}\text { Ecosama - Empresa Concessionária de } \\
\text { Saneamento de Mauá }\end{array}$ & 345.057 & esgoto & $06 / 03 / 2003$ & 30 \\
\hline 20 & Mirassol & SP & Saneamento de Mirassol - Sanessol S. A & 55.000 & plena & $20 / 01 / 2008$ & 30 \\
\hline 21 & Niterói & RJ & Águas de Niterói & 485.000 & plena & 05/11/1999 & 30 \\
\hline 22 & Nova Friburgo & RJ & $\begin{array}{l}\text { CAENF - Concessionária de Águas e } \\
\text { Esgotos de Nova Friburgo }\end{array}$ & 127.705 & plena & 01/07/1999 & 25 \\
\hline 23 & Novo Progresso & PA & Águas de Novo Progresso & 4.400 & plena & $01 / 08 / 2004$ & 30 \\
\hline 24 & Paraguaçu & MG & Concessionária de Saneamento Básico Ltda & 20.920 & plena & 10/11/1999 & 30 \\
\hline 25 & Paranaguá & PR & Águas de Paranaguá & 140.000 & plena & 06/03/1997 & 28 \\
\hline 26 & Pedra Preta & MT & Águas de Pedra Preta S/A & 15.375 & plena & $19 / 12 / 2003$ & 20 \\
\hline 27 & $\begin{array}{l}\text { Peixoto de } \\
\text { Azevedo }\end{array}$ & MT & Águas de Peixoto S/A & 17.978 & plena & $01 / 11 / 2000$ & - \\
\hline 28 & Petrópolis & RJ & Águas do Imperador & 280.000 & plena & 01/01/1998 & 30 \\
\hline 29 & $\begin{array}{l}\text { Pontes e } \\
\text { Lacerda }\end{array}$ & MT & Águas de Pontes e Lacerda S/A & 42.429 & - & - & - \\
\hline 30 & Porto Esperidião & MT & Prefeitura Municipal de Porto Esperidião & 6.100 & - & - & - \\
\hline 31 & $\begin{array}{l}\text { Primavera do } \\
\text { Leste }\end{array}$ & MT & Águas de Primavera & 51.621 & plena & $25 / 08 / 2000$ & 30 \\
\hline 32 & Santa Carmen & MT & Águas de Santa Carmen & 4.414 & plena & $01 / 01 / 2002$ & \\
\hline 33 & Sapezal & MT & Naturagua Distribuidora de Água Itda & 10.971 & - & - & - \\
\hline 34 & $\begin{array}{l}\text { São Pedro da } \\
\text { Cipa }\end{array}$ & MT & VP Gomes Cia Ltda & 3.641 & - & - & - \\
\hline 35 & Sorriso & MT & Águas de Sorriso & 48.660 & plena & $28 / 07 / 2000$ & 30 \\
\hline 36 & Talismã & TO & Hidroforte Administração e Operação Ltda & 1.537 & - & - & - \\
\hline 37 & Querência & MT & Sistema de Abastecimento Água Pura Ltda & 5.000 & - & - & - \\
\hline 38 & União do Sul & MT & Águas de União do Sul S/A & 5.834 & plena & $01 / 11 / 2000$ & - \\
\hline 39 & Vera & MT & Águas de Vera Ltda & 11.499 & plena & $01 / 06 / 2004$ & - \\
\hline
\end{tabular}

Fonte: Elaboração própria da autora baseada em SNIS (2007) e Abcon (2009).

Como foi justificado anteriormente, o Sistema Nacional de Informações sobre Saneamento (SNIS) agrupa apenas uma amostra (apesar de bastante significativa) dos prestadores de serviços de saneamento, inclusive os privados. Dessa forma, é importante traçar um panorama do atual grau de participação privada no setor. Os dados de 2008 da Associação Brasileira das Concessionárias Privadas dos Serviços Públicos de Água e Esgoto, (Abcon) permitem essa análise. Atualmente a participação do setor privado na provisão dos 
serviços de saneamento básico está em 202 municípios (3,6\% do total de municípios do país) e em 12 estados do país. O atendimento fornecido por esses prestadores abrange 9,6\% da população urbana correspondente a 13,6 milhões de habitantes. Existem 48 concessões municipais ou plenas que atendem a 5,3 milhões de habitantes e 30 concessões parciais (de água e/ou esgoto) que atendem a 6,9 milhões de habitantes. A tabela 2.9 sintetiza a evolução do crescimento do setor privado ao longo tempo e faz uma previsão para 2017, quando forem completados dez anos do novo marco regulatório instituído no setor.

Tabela 2.9 - Expectativas de crescimento do setor privado

\begin{tabular}{lccccc}
\hline & $\mathbf{1 9 9 5 - 2 0 0 2}$ & $\mathbf{2 0 0 3 - 0 6}$ & $\mathbf{2 0 0 7}$ & $\mathbf{2 0 0 8}$ & $\begin{array}{c}\text { Previsão } \\
\mathbf{2 0 0 9 - 1 7}\end{array}$ \\
\hline Contratos & 168 & 10 & 12 & 8 & - \\
\% População Urbana & 5 & 6 & 7 & 9,6 & 30 \\
Qt. População Urbana (Milhões) & 7,8 & 8,3 & 10,4 & 13,6 & 42 \\
Crescimento/ano (em R\$) & 1 milhão & 125 mil & 2,1 milhões & 3,2 milhões & 3,5 milhões \\
\hline
\end{tabular}

Fonte: Elaboração própria da autora baseada em Abcon (2008).

Por fim, a última classificação adotada pelo SNIS refere-se ao tipo de serviço prestado pela entidade: pode fornecer somente serviço de abastecimento de água, somente serviços de esgotamento sanitário e pode fornecer tanto um quanto outro serviço conjuntamente. Segue tabela 2.9.1 com a quantidade de empresas em cada uma dessas categorias.

Tabela 2.9.1 - Tipo de serviço prestado por categoria de abrangência

\begin{tabular}{lcccc}
\hline Abrangência & Água & Esgoto & Água e Esgoto & Total \\
\hline Local & 244 & 1 & 326 & 571 \\
Microrregional & 1 & - & 7 & 8 \\
Regional & 2 & - & 24 & 26 \\
Total & $\mathbf{2 4 7}$ & $\mathbf{1}$ & $\mathbf{3 5 7}$ & $\mathbf{6 0 5}$ \\
\hline Fonte: Elaboração própria da autora baseada em SNIS (2007).
\end{tabular}

Como foi enunciado anteriormente, na amostra feita pelo SNIS, cada prestador local atua em um único município, totalizando 571 municípios. A tabela 2.9.2 mostra o número de municípios que cada categoria de prestador regional e microrregional atende, já que cada um deles desagrega as informações para uma determinada amostra de municípios pertencentes ao seu universo de operação. É possível verificar a ampla representatividade da amostra do SNIS frente à quantidade total de municípios do Brasil, que é de 5.564 municípios. Ou seja, a quantidade amostral corresponde a $81,7 \%$ dos municípios brasileiros. No total, esses 
municípios possuem uma população urbana de 147,3 milhões de habitantes $(96,4 \%$ da população urbana do país).

Tabela 2.9.2 - Quantidade de municípios atendidos por cada tipo de prestador

\begin{tabular}{cc|cc}
\hline \multicolumn{2}{c|}{ Prestadores } & \multicolumn{2}{c}{ Quantidade de municípios atendidos } \\
\hline Abrangência & Quantidade & Água & Esgoto \\
\hline Regional & 26 & 3.965 & 1.013 \\
Microrregional & 8 & 21 & 14 \\
Local & 571 & 570 & 328 \\
Brasil & $\mathbf{6 0 5}$ & $\mathbf{4 . 5 5 6}$ & $\mathbf{1 . 3 5 5}$ \\
\hline Fonte: Elaboração própria da autora baseada em SNIS (2007).
\end{tabular}

Fonte: Elaboração própria da autora baseada em SNIS (2007).

A partir da aplicação dos questionários, o SNIS recolhe um montante considerável de dados primários, resultado de contagem ou medição, que é utilizado para o cálculo de diversos indicadores por meio do cruzamento de pelo menos duas ou mais informações primárias.

As informações são agrupadas da seguinte forma: informações operacionais de água e de esgoto relacionadas ao sistema de abastecimento de água e de esgotamento sanitário respectivamente (por exemplo, quantidade de ligações ativas); informações econômicofinanceiras, extraídas dos balanços contábeis das empresas regidas pela Lei das S/A; informações financeiras que correspondem às informações de receita, despesas e investimentos efetivamente realizadas no ano de referência; as informações gerais correspondem a informações sobre a prestação dos serviços, tais como a situação dos contratos de delegação formal, a quantidade de municípios e localidades atendidas, as populações total e urbana, a quantidade de empregados do prestador de serviços, entre outros e, por fim, as informações sobre a qualidade dos serviços correspondem às informações sobre quantidade de paralisações dos sistemas de água, de extravasamentos de esgotos, de qualidade da água distribuída e de intermitências prolongadas nos sistemas de água.

Os indicadores também são agrupados em famílias de mesma natureza tais como indicadores econômico-financeiros e administrativos; indicadores operacionais - água; indicadores operacionais - esgoto; indicadores de balanço contábil e indicadores sobre a qualidade dos serviços. 


\section{Capítulo 3. MENSURAÇÃO DE EFICIÊNCIA E ANÁLISE DESCRITIVA.}

\section{1) Eficiência no setor de saneamento.}

O argumento da baixa eficiência dos prestadores de serviços é utilizado como uma das explicações para a deficiência do setor em termos de investimento, geração de excedentes e, conseqüentemente, no longo prazo, descumprimento das metas estabelecidas para o setor.

A análise econômica considera que a mensuração da eficiência do setor público se torna fundamental para análise de reformas, como projetos de privatização e introdução de novos mecanismos de regulação, ainda mais considerando a realidade do setor, que enfrenta inúmeros desafios na questão da concretização do marco regulatório anunciado pela nova lei federal do setor de saneamento.

Existem três principais formas possíveis de se estimar eficiência, uma delas é o método paramétrico, baseado em funções de fronteira, como a fronteira estocástica, por exemplo. Esse é mais exigente, pois é necessário que se faça pressuposições sobre a função de produção, de custo ou de lucro. Dada a especificação dessa função, as medidas de eficiência podem variar de acordo com a fronteira tecnológica escolhida. Contudo, é mais rico e consistente em relação aos testes de hipóteses.

O outro método, chamado de Data Envelopment Analysis (DEA), é não paramétrico, ou seja, não pressupõe uma função de produção com parâmetros a serem estimados e também não associa ao modelo qualquer estrutura de probabilidade. Por meio de programação matemática, estabelece apenas que a forma da fronteira do conjunto de produção deve satisfazer certas propriedades.

Por fim, a regressão por Mínimos Quadrados Ordinários (MQO) estima eficiência por meio do estabelecimento de índices de desempenho (definidos por uma relação entre produção/insumos). Sua vantagem é que é mais útil e mais fácil de ser usado enquanto a desvantagem é que impede uma visão geral de uma unidade de produção, ao impossibilitar a utilização de uma função de produção multi-produto, por exemplo, com várias entradas e saídas no processo produtivo.

Turolla e Ohira (2007) afirmam que todos os métodos enfrentam seus próprios problemas, tanto teóricos quanto práticos, e isso implica que as estimativas finais de eficiência 
não devem ser interpretadas como sendo medidas definitivas de ineficiência (TUROLLA; OHIRA, 2007, p. 208). Portanto, na escolha de qual método utilizar, é importante identificar aquele que irá responder de maneira mais adequada a pergunta feita pelo pesquisador. Nesse estudo, optou-se pelo método de MQO, a fim de estabelecer um retrato atual do setor em termos de desempenho dos diferentes tipos de provedores de serviços.

Segundo Turolla, Ohira e Lima (2008), "o desempenho dos prestadores de serviços regulados deve ser quantificado para que seja possível ratear os ganhos de eficiência entre usuários e prestadores, ou até mesmo a divisão das perdas através de tributos ou outros mecanismos de alocação" (TUROLLA; OHIRA; LIMA, 2008, p.148).

É importante levantar os resultados dos principais autores que estudaram o tema relacionado à eficiência ou desempenho das empresas fornecedoras de serviços de saneamento, mesmo que utilizem métodos diferentes ao que será utilizado nesse trabalho, a fim de verificar se existe alguma convergência de opinião e/ou recomendação entre os autores nas conclusões que obtiveram.

Castro (2003) avaliou a eficiência das 71 maiores empresas do setor, para o ano de 2000, segundo o número de ligações ativas de água, através da metodologia DEA, com retornos variáveis de escala. Entre as 71 empresas, 22 eram de abrangência regional e 49 locais. Entre as 49 unidades locais, 13 ficaram na faixa entre 30\% e 50\% de eficiência; 17 estiveram entre $50 \%$ e $70 \%$; sete entre $70 \%$ e $90 \%$; e 12 entre $90 \%$ e $100 \%$. Já as 23 unidades regionais são relativamente mais homogêneas: nenhuma ficou abaixo de $50 \%$; 3 estão entre $50 \%$ e $70 \%$; 9 entre $70 \%$ e $90 \%$ e 10 entre $90 \%$ e $100 \%$.

Tupper e Resende (2004) selecionaram 20 companhias estaduais e analisaram sua eficiência também através do DEA. O índice de eficiência ajustado variou de 50,9\% a 100\% e sua média foi de $79,9 \%$, mas a variabilidade se apresentou limitada: o desvio padrão equivaleu a $12,6 \%$ do valor médio. Os índices de eficiência encontrados por Tupper e Resende, para as empresas estaduais, parecem corroborar a avaliação de Castro (2003), sugerindo que a heterogeneidade interna nesse grupo é menor que a observada entre os serviços locais.

Ohira e Shirota (2005) mensuram, de forma alternativa, a eficiência no setor, por meio do modelo de fronteira estocástica, para 179 empresas, verificando a existência de eficiência econômica entre empresas de saneamento básico no Estado de São Paulo. Os resultados obtidos pelos autores permitem concluir que essas empresas apresentam um grande intervalo quanto ao nível de eficiência em relação às fronteiras de custo estimada, ou seja, indica que 
existe um significativo potencial para o aprimoramento gerencial das empresas. Além disso, testes realizados demonstraram que a diferenciação por esfera de abrangência (regional e local) não foi significativa para a determinação de um resultado eficiente: isso significa que os dois tipos de empresas têm desempenhos semelhantes com relação aos custos operacionais.

Para determinar o grau de eficiência das empresas de saneamento brasileiras, Sampaio, B. e Sampaio, Y. (2007) utilizaram o método de análise envoltória de dados (DEA). Os autores consideraram cada uma das trinta e seis empresas de saneamento escolhidas entre os anos de 1998 a 2003, como uma unidade tomadora de decisão (DMU). Essas DMUs foram avaliadas por suas eficiências relativas às unidades identificadas como eficientes, que compõem a fronteira tecnológica.

Os autores mostram que, ao lado das variáveis ligadas ao desempenho da empresa, tais como variáveis operacionais, geográficas e políticas, se destacaram aquelas que relacionam eficiência ao ciclo político, tais como a continuidade administrativa e a coincidência de partido na gestão municipal e estadual. O efeito positivo destas variáveis sobre a eficiência das empresas analisadas indica que o impacto do comportamento eleitoreiro dos políticos pode ser bastante prejudicial para o setor, uma vez que a alternância de poder nas prefeituras, por exemplo, pode levar à descontinuidade nos projetos pelo desejo de marcar a administração por mudanças.

Os autores comprovaram também que a privatização atenua as influências políticas. Contudo, se sua propagação ocorrer sem a presença de marco regulatório, pode reforçar as desigualdades de atendimento entre regiões e diferentes estratos sociais.

O principal trabalho na literatura sobre eficiência é de Motta e Moreira (2004), que analisaram o setor de saneamento de forma abrangente usando o DEA, considerando todos os operadores do território nacional. A amostra foi composta de 104 operadores (73 locais, 20 regionais e 11 privados). Os autores apontam que os efeitos de catch up, ou seja, movimentos em direção à fronteira tecnológica, são mais importantes que o crescimento da produtividade total de fatores, no período 1997-2002. A introdução de gestão privada foi um fator relevante de contribuição para movimentos em direção à fronteira. $\mathrm{O}$ estudo também avalia que os operadores regionais realmente se beneficiam de economias de escala, mas que operam com níveis mais baixos de produtividade e não foram capazes de ganhar produtividade no mesmo ritmo dos operadores locais no período analisado.

As conclusões apontadas pelos autores indicam que a falta de regulação no setor de saneamento não estimula avanços em direção à fronteira tecnológica, tendo em vista que não 
há regulação voltada para o incentivo aos ganhos de produtividade. Estabelecer esses incentivos de maior produtividade foi um dos dispositivos estabelecidos pela nova lei federal. Portanto, nesse novo contexto regulatório do setor, ganhos produtivos podem se reverter em ganhos de bem-estar de forma que a população seja beneficiada.

Motta e Moreira (2004) avaliam que as operadoras locais públicas e privadas têm níveis semelhantes de produtividade. As operadoras regionais, que correspondem basicamente às companhias estaduais nascidas no PLANASA, têm nível de eficiência inferior ao das operadoras locais. No conjunto das estaduais, o estudo aponta que existe rentabilidade negativa associada a salários das mesmas, a perdas e alta inadimplência, além de não contarem com algumas vantagens tributárias que caracterizam as locais. Entretanto, há que se notar que, apesar disso, as companhias estaduais vêm investindo e ampliando sua infraestrutura em ritmo mais pronunciado que os serviços municipais.

É possível perceber, a partir dos resultados dos estudos mencionados, principalmente o último, que há uma forte heterogeneidade de desempenho entre os diversos tipos de prestadores. Além disso, há um maior destaque das locais, tanto das públicas locais quanto das privadas locais, sobre as estaduais (ou regionais) em relação a níveis de eficiência. Esse resultado é ainda mais intrigante, quando esse estudo indica que, conforme esperado pela sua maior abrangência territorial, as estaduais operam com ganhos de escala maiores que as locais. Ou seja, tal resultado indica que o prestador estadual monopolista dissipa ganhos de renda e, conseqüentemente, compromete a expansão dos serviços e metas de universalização.

Conforme apontou revisão bibliográfica dos resultados dos principais trabalhos que estimam eficiência, as conclusões obtidas não trazem uma solução de qual tipo de empresa ou qual arranjo entre elas é preferível para que o setor encontre condições de atingir a universalização dos serviços. Ao considerar o complexo ambiente institucional no qual o mesmo está inserido é possível afirmar que a superação dos impasses para o desafio da universalização não se encontra apenas no melhor arranjo entre os diversos tipos de empresas e, sim, numa composição de fatores, entre eles a execução adequada do novo marco regulatório e a articulação entre os vários setores da sociedade, como estabelecido pela nova lei federal de janeiro de 2007.

Turolla e Ohira (2007) propõem "como encaminhamento para os principais desafios do setor de saneamento, a discussão de uma combinação de dois vetores de reestruturação: um vetor de regulação combinado a outro de agregação" (TUROLLA; OHIRA, 2007). Ainda 
segundo os mesmos autores, “(...) se o objetivo é a agregação dos serviços, o melhor modelo pode não ser o atual modelo de companhias estaduais, mas outras formas de agregação".

Assim, esse estudo, ao partir do pressuposto que a nova lei federal proporcionou regulação adequada ${ }^{27}$ para o setor e no contexto atual de aumento da participação privada no mesmo, pretende verificar se existe alguma configuração institucional entre os provedores de serviços de saneamento, não identificada em estudos anteriores, que proporcione melhor desempenho nos indicadores selecionados. Dessa forma, por meio de investigação de quais campos de atuação um ou outro tipo de empresa mais se destaca, é sugerida, quando possível, a melhor composição entre elas. O método de análise empírica escolhido foi o de Mínimos Quadrados Ordinários, para dados em cross section, por proporcionar um reflexo da situação atual do setor e possibilitar o estabelecimento de um benchmarking para fins de regulação ou de acompanhamento de desenvolvimento do mesmo.

Além disso, irão ser discutidas as vantagens de parcerias público-privadas, que se mostram como uma possibilidade de alavancar novos investimentos e fornecer condições para o cumprimento dos objetivos perseguidos pelo setor. Essas parcerias refletem, conseqüentemente, o grau de participação do setor privado no saneamento básico brasileiro. É importante destacar que a avaliação de eficiência ocorrerá por meio da análise dos níveis de desempenho de cada tipo de prestador para, posteriormente, fazer a composição geral de todos os indicadores e verificar qual apresentou melhores resultados e, portanto, é mais eficiente.

\section{2) Caracterização da cobertura dos serviços sanitários (2002/2007).}

Nessa seção, será desenvolvida uma análise descritiva da evolução da cobertura dos serviços de saneamento básico (por meio dos indicadores relativos ao índice de atendimento total de água e esgoto, por município) no início dessa década, ano $2002^{28}$, e no final da mesma, publicação mais recente do SNIS, que é o ano de 2007. Essa análise será feita segundo algumas características municipais tais como região geográfica em que se localiza o município, porte (tamanho da população), taxa de urbanização e renda per capita.

$\mathrm{O}$ indicador relativo ao índice de atendimento total de água refere-se à razão entre a população total atendida com abastecimento de água e a população total do município

\footnotetext{
${ }^{27}$ Tanto em relação a questões normativas quanto à execução das mesmas.

${ }^{28} \mathrm{O}$ ano de 2002 foi escolhido também por referência ao artigo de Toneto e Saiani (2006).
} 
atendido com abastecimento de água, ou seja, aquele que possui em sua localidade um prestador de serviço de saneamento operante. O indicador relativo ao índice total de esgoto refere-se à razão entre a população total atendida com esgotamento sanitário e a população total do município atendido com abastecimento de água. É preciso destacar que tais estatísticas foram calculadas, em 2007, exatamente para os mesmos municípios de 2002: total de 1789 municípios. Optou-se por selecionar os mesmos municípios para que os valores encontrados não fossem afetados por mudanças de incorporação de novos prestadores e o abandono de outros, que a amostra sofre, ao longo dos anos. Além disso, usou-se a média ponderada, pelo peso da população total em cada município (segundo o IBGE) para não distorcer os valores da média nacional.

O objetivo dessa apresentação é verificar e diferenciar a evolução da cobertura em dois momentos distintos referentes à privatização. O primeiro período (2002) marca o momento em que grande parte das concessões municipais começou a vencer. A maioria delas foi celebrada num período de vigência de trinta anos e, após o vencimento das mesmas, os municípios deveriam estabelecer novos contratos. O outro período foi escolhido por ser o mais recente da série e por indicar as tendências para as políticas públicas atuais ${ }^{29}$.

Na tabela 3.1, que classifica os municípios, por região geográfica, é possível verificar que as regiões Norte e Nordeste, em 2007, apresentaram índices abaixo da média nacional e as outras regiões apresentaram índices semelhantes entre si, e superior a mesma média, em termos do atendimento total de água. Em relação ao índice de atendimento total de esgoto, para o mesmo ano, somente a região Sudeste apresentou índice superior à média do país. Ainda considerando esse índice, pode-se falar em convergência no indicador, pois aquela região que obteve o menor valor para o mesmo (Norte) registrou também a maior expansão de atendimento entre os dois anos. Para a água, essa evidência não se verifica, pois a maior expansão ocorreu na região Centro Oeste que, por sua vez, registrou um dos maiores índices de atendimento de água entre todas as regiões.

\footnotetext{
${ }^{29}$ É importante destacar que a amostragem municipal do SNIS, para 2007, foi de 81,9\%. Devido a esse fato, temos uma média de cobertura (para água e esgoto) inferior ao que se obtém geralmente, quando se considera os dados do Censo, por exemplo.
} 
Tabela 3.1 - Índice de atendimento total de água e esgoto por região geográfica

\begin{tabular}{lccc}
\hline \multicolumn{3}{l}{ Índice de atendimento total de água [percentual] } \\
\hline Regiões & $\mathbf{2 0 0 2}$ & $\mathbf{2 0 0 7}$ & $\begin{array}{c}\text { Variação } \\
\mathbf{2 0 0 2 - 0 7}(\%)\end{array}$ \\
& & & 4,05 \\
\hline Centro Oeste & 85,91 & 89,39 & $-0,55$ \\
Sudeste & 89,03 & 88,53 & 0,78 \\
Sul & 89,12 & 89,81 & $-4,96$ \\
Norte & 57,64 & 54,78 & $-2,83$ \\
Nordeste & 76,00 & 73,85 & $-0,80$ \\
Total & 83,23 & 82,56 & 12,35 \\
Índice de atendimento total de esgoto [percentual \\
\hline Centro Oeste & 40,51 & 45,52 & 2,41 \\
Sudeste & 65,48 & 67,06 & 19,84 \\
Sul & 30,83 & 36,94 & 35,94 \\
Norte & 3,77 & 5,13 & 2,90 \\
Nordeste & 22,57 & 23,23 & 16,97 \\
Total & 43,46 & 50,83 & \\
\hline Fonte: Elaboração própria da autora & baseada em \\
SNIS (2002 e 2007). &
\end{tabular}

A tabela 3.2 apresenta os valores desses mesmos índices segmentados por faixas de população ou porte dos municípios. Percebe-se, pela análise dos indicadores que, quanto maior a população do município maior o índice de atendimento total de água e esgoto. Porém, de acordo com essa segmentação, a convergência não se verifica, nem para a água e nem para esgoto, uma vez que a faixa que deveria apresentar maior expansão, para cada caso, seria a de 10 a 20.000 habitantes e 5 a 10.000 habitantes, respectivamente. 
Tabela 3.2 - Índice de atendimento total de água e esgoto por população municipal

\begin{tabular}{|c|c|c|}
\hline \multicolumn{3}{|c|}{ Índice de atendimento total de água [percentual] } \\
\hline Porte & 20022007 & $\begin{array}{c}\text { Variação } \\
\text { 2002-07 (\%) }\end{array}$ \\
\hline Até 5.000 hab. & $59,36 \quad 66,16$ & 11,46 \\
\hline 5.000 a 10.000 hab. & $58,27 \quad 64,24$ & 10,24 \\
\hline 10.000 a 20.000 hab. & $60,13 \quad 63,77$ & 6,04 \\
\hline 20.000 a 50.000 hab. & $61,85 \quad 67,69$ & 9,44 \\
\hline 50.000 a 100.000 hab. & $74,90 \quad 75,39$ & 0,66 \\
\hline 100.000 a 500.000 hab. & $86,7184,87$ & $-2,12$ \\
\hline 500.000 a 1.000 .000 hab. & $89,00 \quad 77,05$ & $-13,43$ \\
\hline Mais de $1.000 .000 \mathrm{hab}$. & $95,25 \quad 94,74$ & $-0,54$ \\
\hline Total & $83,1182,56$ & $-0,66$ \\
\hline \multicolumn{3}{|c|}{ Índice de atendimento total de esgoto [percentual] } \\
\hline Até 5.000 hab. & $9,99 \quad 10,85$ & 8,58 \\
\hline 5.000 a 10.000 hab. & $7,02 \quad 8,00$ & 14,09 \\
\hline 10.000 a 20.000 hab. & $6,20 \quad 9,40$ & 51,67 \\
\hline 20.000 a 50.000 hab. & $13,09 \quad 16,12$ & 23,18 \\
\hline 50.000 a 100.000 hab. & $21,95 \quad 25,14$ & 14,51 \\
\hline 100.000 a 500.000 hab. & $44,27 \quad 46,40$ & 4,82 \\
\hline 500.000 a 1.000 .000 hab. & $48,74 \quad 43,30$ & $-11,17$ \\
\hline Mais de $1.000 .000 \mathrm{hab}$. & $71,40 \quad 72,23$ & 1,17 \\
\hline Total & $43,46 \quad 50,83$ & 16,97 \\
\hline
\end{tabular}

A mesma análise das tabelas anteriores pode ser aplicada quando se leva em consideração as diferentes taxas de urbanização dos municípios, evidenciadas na tabela 3.3. Sob esse ponto de vista, é possível destacar o aumento do índice de água e esgoto à medida que se eleva o grau de urbanização de tais municípios. É possível perceber que a convergência ocorre de uma forma indireta, pois as faixas que registraram maior expansão de ambos os índices estão entre a taxa de 50 a $80 \%$ de urbanização, com exceção daquelas faixas que apresentaram queda nos mesmos entre os dois anos. Porém, a análise individual de cada segmento não aponta convergência estrita. 
Tabela 3.3 - Índice de atendimento total de água e esgoto por taxa de urbanização

\begin{tabular}{lccc}
\hline \multicolumn{4}{l}{ Índice de atendimento total de água [percentual] } \\
\hline Taxa de urbanização & $\mathbf{2 0 0 2}$ & $\mathbf{2 0 0 7}$ & $\begin{array}{c}\text { Variação } \\
\mathbf{2 0 0 2 - 0 7}(\%)\end{array}$ \\
\hline Menos de 50\% & 35,75 & 35,61 & $-0,40$ \\
de 50\% a 60\% & 49,63 & 51,38 & 3,52 \\
de 60\% a 70\% & 60,77 & 60,36 & $-0,67$ \\
de 70\% a 80\% & 71,43 & 74,18 & 3,85 \\
de 80\% a 90\% & 80,48 & 81,06 & 0,72 \\
de 90\% a 95\% & 91,64 & 91,10 & $-0,58$ \\
mais de 95\% & 91,00 & 87,49 & $-3,86$ \\
Total & 83,11 & 82,56 & $-0,66$ \\
Índice de atendimento total de esgoto [percentual \\
\hline Menos de 50\% & 2,07 & 1,99 & $-3,93$ \\
de 50\% a 60\% & 3,70 & 4,33 & 16,91 \\
de 60\% a 70\% & 4,63 & 5,70 & 23,06 \\
de 70\% a 80\% & 14,43 & 16,72 & 15,91 \\
de 80\% a 90\% & 23,04 & 25,34 & 9,98 \\
de 90\% a 95\% & 58,53 & 61,07 & 4,34 \\
mais de 95\% & 54,84 & 55,02 & 0,32 \\
Total & 43,46 & 50,83 & 16,97 \\
\hline Fonte: Elaboração própria da & autora & baseada em \\
SNIS (2002 e 2007). & &
\end{tabular}

Por fim, o último aspecto investigativo, refere-se à segmentação por renda per capita, conforme tabela 3.4. A relação positiva entre o aumento dos indicadores de atendimento de água e esgoto e a renda per capita dos municípios destaca-se de forma aparente na evolução dos dados ao longo dos cortes estabelecidos. Esse é o único caso em que a convergência se aplica para ambos os índices. 
Tabela 3.4 - Índice de atendimento total de água e esgoto por renda per capita.

\begin{tabular}{|c|c|c|}
\hline \multicolumn{3}{|c|}{ Índice de atendimento total de água [percentual] } \\
\hline Renda per Capita & 20022007 & $\begin{array}{c}\text { Variação } \\
\text { 2002-07 (\%) }\end{array}$ \\
\hline até US\$2000 & $39,43 \quad 43,30$ & 9,82 \\
\hline de US\$2000 a US\$3000 & $58,53 \quad 63,41$ & 8,35 \\
\hline de US\$3000 a US\$5000 & $69,83 \quad 73,25$ & 4,90 \\
\hline de US\$5000 a US\$7000 & $80,3175,51$ & $-5,98$ \\
\hline de US\$7000 a US\$9000 & $84,8984,70$ & $-0,22$ \\
\hline de US\$9000 a US\$11000 & $92,02 \quad 93,48$ & 1,59 \\
\hline de US\$11000 a US\$200000 & $93,52 \quad 94,92$ & 1,50 \\
\hline de US\$20000 a US\$400000 & $88,7980,90$ & $-8,89$ \\
\hline Mais que US\$40000 & $82,70 \quad 75,86$ & $-8,28$ \\
\hline Total & $83,1182,56$ & $-0,66$ \\
\hline \multicolumn{3}{|c|}{ Índice de atendimento total de esgoto [percentual] } \\
\hline até US\$2000 & $0,28 \quad 0,73$ & 166,39 \\
\hline de US\$2000 a US\$3000 & $5,25 \quad 7,90$ & 50,34 \\
\hline de US\$3000 a US\$5000 & $18,5928,73$ & 54,52 \\
\hline de US\$5000 a US\$7000 & $25,90 \quad 32,11$ & 23,98 \\
\hline de US\$7000 a US\$9000 & $41,85 \quad 41,56$ & $-0,69$ \\
\hline de US\$9000 a US\$11000 & $53,48 \quad 61,45$ & 14,91 \\
\hline de US\$11000 a US\$200000 & $67,86 \quad 68,70$ & 1,25 \\
\hline de US\$20000 a US\$400000 & $54,68 \quad 51,27$ & $-6,23$ \\
\hline Mais que US\$40000 & $35,46 \quad 35,89$ & 1,21 \\
\hline Total & $43,46 \quad 50,83$ & 16,97 \\
\hline
\end{tabular}

Após essa análise descritiva, na próxima seção, será feita também outra segmentada dentro de cada grupo de indicadores do SNIS, para o mesmo período, segundo a abrangência e a natureza jurídica dos prestadores, para verificar o desempenho de cada tipo de prestador em cada indicador específico. Pretende-se buscar evidências se há um padrão diferenciado no que diz respeito à eficiência e à capacidade de investimento entre os diversos prestadores atuantes no setor. Para fundamentar essa análise, posteriormente são construídas possíveis funções-objetivo de cada tipo de prestador a fim de que os resultados aprovem ou reprovem o que é tradicionalmente enunciado pela literatura do setor.

\section{3) Desempenho médio por tipo de prestador (2002/2007).}

As estatísticas descritivas, acerca dos principais indicadores, utilizados por Saiani e Toneto Junior (2006), serão utilizadas para verificar as discrepâncias mais aparentes entre a 
média dos diferentes tipos de prestadores. A comparação será entre empresas regionais (como, por exemplo, a Sabesp que atende 367 municípios), locais públicas (aquelas que atuam em apenas um município, como a Sanasa de Campinas), as locais privadas (empresas privadas municipais que também atuam em um único município, como a Águas do Amazonas S.A. em Manaus) e empresa privada, que são todas aquelas classificadas dessa forma na amostra do SNIS independente da abrangência regional (por exemplo, Prolagos faz parte desse grupo, a SANEATINS e inclusive todas as locais privadas acima mencionadas). Os dados apresentados consideram os valores médios para as variáveis em cada grupo. $\mathrm{O}$ primeiro grupo a ser analisado é o dos indicadores operacionais de água e esgoto. Segue, em primeiro lugar, a tabela 3.5 com os valores dos indicadores operacionais de água, para cada tipo de prestador.

Tabela 3.5 - Indicadores Operacionais de Água

\begin{tabular}{|c|c|c|c|c|c|c|c|c|c|c|}
\hline \multirow{3}{*}{$\begin{array}{l}\text { Indicador Ope racional } \\
\text { Água }\end{array}$} & \multicolumn{3}{|c|}{ Regional } & \multicolumn{3}{|c|}{ Local Público } & \multicolumn{3}{|c|}{ Local Privado } & \multirow[t]{2}{*}{$\begin{array}{c}\text { Empresa } \\
\text { Privada } \\
\end{array}$} \\
\hline & & & Variação & & & Variação & & & Variação & \\
\hline & 2002 & 2007 & $\begin{array}{c}2002-07 \\
(\%)\end{array}$ & 2002 & 2007 & $\begin{array}{c}2002-07 \\
(\%)\end{array}$ & 2002 & 2007 & $\begin{array}{c}2002-07 \\
(\%)\end{array}$ & 2007 \\
\hline İ́ndic & & 2 & 11,33 & 43,00 & 31,22 & $-27,40$ & 49,90 & 21,01 & $-57,90$ & 2,43 \\
\hline Índice de Perdas na Distribuiçã & 44,50 & 49,06 & 10,25 & 39,30 & 28,10 & $-28,50$ & 42,90 & 27,36 & 36,22 & 8,74 \\
\hline Índice de Hidrometração [\%] & 87,40 & 76,55 & $-12,41$ & 90,10 & 82,83 & $-8,07$ & 79,40 & 95,84 & 20,71 & 95,98 \\
\hline $\begin{array}{l}\text { Densidade de Economias por Ligação } \\
\text { [econ/lig] }\end{array}$ & 1,32 & 1,22 & $-7,58$ & 1,26 & 1,08 & $-14,29$ & 1,37 & 1,20 & $-12,41$ & 1,21 \\
\hline $\begin{array}{l}\text { Extensão rede água por ligação } \\
\text { [m/ligação] }\end{array}$ & 11,20 & 12,20 & 8,93 & 11,90 & 16,41 & 37,90 & 12,80 & 17,43 & 36,17 & 17,33 \\
\hline $\begin{array}{l}\text { Consumo médio de água } \\
{\left[\mathrm{m}^{3} / \mathrm{mês} / \text { economia }\right]}\end{array}$ & 14,30 & 14,15 & $-1,05$ & 17,60 & 18,95 & 7,67 & 15,80 & 13,68 & $-13,42$ & 13,51 \\
\hline Consumo médio per capita $[1 / \mathrm{hab} / \mathrm{dia}]$ & 142,60 & 129,76 & $-9,00$ & 184,30 & 173,18 & $-6,03$ & 155,80 & 128,44 & $-17,56$ & 128,10 \\
\hline Índice de Atendimento Urbano [\%] & 90,40 & 88,32 & $-2,30$ & 97,90 & 95,45 & $-2,50$ & 87,10 & 92,64 & 6,36 & 93,31 \\
\hline Índice de Atendimento Total [\%] & 76,60 & 71,19 & $-7,06$ & 92,90 & 84,72 & $-8,81$ & 88,30 & 79,20 & $-10,31$ & 79,97 \\
\hline
\end{tabular}

Verifica-se um destaque dos prestadores públicos locais em relação aos índices de atendimento urbano e total de água e em relação ao consumo médio de água total e per capita. Ou seja, existe uma tendência de que os indicadores de acesso sejam maiores nos locais públicos do que nos prestadores regionais. No ano de 2006, essa tendência também se verificou.

Já os melhores índices de perdas de faturamento e de distribuição são das locais privadas, em 2007, em detrimento dos piores das regionais, o que pode indicar que aquelas apresentam uma melhor tecnologia que promove a distribuição de água de forma mais eficiente, construindo sistemas voltados para minimizar perdas. Verifica-se, ao comparar os 
dados de 2007 com os de 2002, que as empresas locais privadas registraram uma significativa diminuição desses índices (queda de 57,90\% e 36,22\%), seguidas das locais públicas que também melhoram tais índices, mas não na mesma proporção (queda de 27,40\% e 28,50\%).

Nesse contexto, para o ano de 2007, as empresas privadas apresentam melhores índices de hidrometração, com diferença pequena em relação às locais privadas, fato que pode ser justificado pelo mesmo argumento. Entre os dois anos, o aumento desse índice para essas últimas foi de $20 \%$ enquanto para os outros tipos de prestadores houve queda desse índice. É possível perceber que as empresas privadas seguem aproximadamente os mesmos valores que o grupo das locais privadas, com exceção do índice de densidade de economias por ligação, que foi maior que o valor dos prestadores locais públicos e privados, mas menor que os regionais. Nos outros indicadores não existe diferenças significativas entre os prestadores.

Ao partir para a análise do grupo de indicadores operacionais de esgoto, temos os seguintes dados para os mesmos tipos de prestadores, apresentados na tabela 3.6:

Tabela 3.6 - Indicadores Operacionais de Esgoto

\begin{tabular}{|c|c|c|c|c|c|c|c|c|c|}
\hline \multirow[t]{2}{*}{ Indicador Operacional } & \multicolumn{3}{|c|}{ Regional } & \multicolumn{3}{|c|}{ Local Público } & \multicolumn{2}{|c|}{ Local Privado } & $\begin{array}{c}\text { Empresa } \\
\text { privada }\end{array}$ \\
\hline & 2002 & 2007 & $\begin{array}{c}\text { Variação } \\
\text { 2002-07 } \\
(\%)\end{array}$ & 2002 & 2007 & $\begin{array}{c}\text { Variação } \\
\text { 2002-07 } \\
(\%)\end{array}$ & 20022007 & $\begin{array}{c}\text { Variação } \\
\text { 2002-07 } \\
(\%)\end{array}$ & 2007 \\
\hline Índice de Coleta de Esgoto [\%] & 47,00 & 29,52 & $-37,19$ & 71,90 & 68,80 & $-4,31$ & $61,20 \quad 66,77$ & 9,10 & 64,35 \\
\hline Índice de Tratamento de Esgoto [\%] & 67,20 & 79,83 & 18,79 & 22,60 & 44,40 & 96,46 & $45,5070,71$ & 55,41 & 73,50 \\
\hline Esgoto tratado/água consumida [\%] & 31,60 & 24,50 & $-22,47$ & 16,50 & 25,47 & 54,36 & $29,80 \quad 44,11$ & 48,02 & 41,86 \\
\hline Índice de Atendimento Urbano [\%] & 38,60 & 37,14 & $-3,78$ & 79,20 & 78,54 & $-0,83$ & $34,80 \quad 66,21$ & 90,26 & 61,34 \\
\hline Índice de Atendimento Total [\%] & 32,50 & 23,06 & $-29,05$ & 75,80 & 70,25 & $-7,32$ & $35,10 \quad 60,67$ & 72,85 & 54,93 \\
\hline
\end{tabular}

Fonte: Elaboração própria da autora baseada em SNIS (2002 e 2007).

Para 2007, os prestadores locais públicos também apresentam melhor índice para coleta de esgoto. Contudo, a diferença em relação ao prestador local privado é pequena. Em relação ao índice de tratamento de esgoto o melhor desempenho é das empresas regionais.

Assim como no ano anterior, as locais públicas continuam coletando mais e tratando menos e as regionais continuam tratando mais e coletando menos. Segundo Toneto e Saiani (2006), o melhor índice relacionado à coleta, por parte das públicas locais, reflete que essas empresas preocupam-se em afastar seu esgoto para limites fora do seu município. Já as regionais, por atender a uma maior gama de municípios, não pode se valer dessa estratégia, pois o afastamento do esgoto afetará os outros municípios em que atua. 
O maior índice de tratamento de esgoto pelas regionais pode estar relacionado também às maiores economias de escala que essas empresas obtêm e que faz com que possam ter mais condições de investir na custosa etapa do tratamento de esgoto. Destaca-se na comparação dos indicadores, entre os dois anos, que o maior crescimento foi de 96,46\% para os locais públicos, seguido dos privados cujo crescimento foi de 55,41\%. Contudo, o maior crescimento dos públicos pode estar relacionado ao fato de ter partido de baixos índices.

Por fim, nos indicadores de atendimento urbano e total de esgoto, o maior valor registrado é o das públicas locais novamente. Cabe aqui ressaltar que esse resultado pode revelar um viés a favor desse grupo, uma vez que atuam em municípios que optaram por não conceder a prestação de serviços pelo fato de já apresentarem uma escala ótima, que favorece a manutenção da prestação municipal.

É possível concluir da análise desse primeiro grupo de indicadores que não existe um tipo de prestador que é mais eficiente em todas, ou na maioria das variáveis. A análise segue com o grupo de indicadores econômicos, financeiros e administrativos para os anos 2002 e 2007, cujos valores são expostos na tabela 3.7 . 
Tabela 3.7 - Indicadores Econômicos, Financeiros e Administrativos

\begin{tabular}{|c|c|c|c|c|c|c|c|c|c|c|}
\hline \multirow[b]{3}{*}{ Indicadores } & \multicolumn{3}{|c|}{ Regional } & \multicolumn{3}{|c|}{ Local Público } & \multicolumn{3}{|c|}{ Local Privado } & \multirow[t]{2}{*}{$\begin{array}{c}\text { Empresa } \\
\text { Privada }\end{array}$} \\
\hline & & & Variaçã & & & Variaçã & & & Variação & \\
\hline & 2002 & 2007 & $\begin{array}{l}\text { o } 2002- \\
07(\%)\end{array}$ & 2002 & 2007 & $\begin{array}{l}\text { o } 2002- \\
07(\%)\end{array}$ & 2002 & 2007 & $\begin{array}{c}2002-07 \\
(\%)\end{array}$ & 2007 \\
\hline $\begin{array}{l}\text { Índice de Produtividade: Economias Ativas por pessoal próprio } \\
\text { [econ/empreg] }\end{array}$ & 563,00 & 479,51 & $-14,83$ & 380,00 & 377,71 & $-0,60$ & 617,00 & 466,36 & $-24,41$ & 456,15 \\
\hline Índice de Produtividade: Economias por pessoal total [econ/empreg. eqv.] & 392,00 & 321,00 & $-18,11$ & 237,00 & 248,28 & 4,76 & 397,00 & 286,33 & $-27,88$ & 282,50 \\
\hline $\begin{array}{l}\text { Índice de produtividade: empregados próprios por } 1000 \text { ligações de água } \\
\text { [empreg./mil lig.] }\end{array}$ & 3,40 & 4,40 & 29,41 & 5,80 & 5,54 & $-4,48$ & 3,20 & 3,70 & 15,63 & 3,79 \\
\hline $\begin{array}{l}\text { Índice de produtividade: empregados próprios por } 1000 \text { ligações de água }+ \\
\text { esgoto [empreg./mil lig.] }\end{array}$ & 2,50 & 3,81 & 52,40 & 3,40 & 4,24 & 24,71 & 2,30 & 3,13 & 36,09 & 3,17 \\
\hline Despesa Total com Serviço por $\mathrm{m}^{3}$ Faturado $\left[\mathrm{r} \$ / \mathrm{m}^{3}\right]$ & 1,40 & 2,38 & 70,00 & 0,73 & 0,93 & 27,40 & 1,27 & 1,52 & 19,69 & 1,59 \\
\hline Despesa de Exploração por $\mathrm{m}^{3}$ faturado $\left[\mathrm{r} \$ / \mathrm{m}^{3}\right]$ & 0,82 & 1,80 & 119,51 & 0,67 & 0,88 & 31,34 & 0,71 & 1,18 & 66,20 & 1,21 \\
\hline Despesa de exploração por economia [r\$/ano/econ.] & 165,28 & 329,66 & 99,46 & 121,85 & 157,55 & 29,30 & 150,36 & 205,55 & 36,71 & 205,18 \\
\hline Participação Despesa Pessoal Total na Despesa de Exploração [\%] & 64,00 & 60,63 & $-5,27$ & 65,50 & 54,84 & $-16,27$ & 43,10 & 46,88 & 8,77 & 46,43 \\
\hline Tarifa média praticada $\left[\mathrm{r} \$ / \mathrm{m}^{3}\right]$ & 1,25 & 1,93 & 54,40 & 0,81 & 0,97 & 19,75 & 1,21 & 1,67 & 38,02 & 1,72 \\
\hline Índice de evasão de receitas [percentual] & 11,00 & 12,28 & 11,64 & 4,50 & 1,71 & $-62,00$ & 15,80 & 5,42 & $-65,70$ & 5,66 \\
\hline Margem da Despesa de Exploração [percentual] & 65,80 & 106,29 & 61,53 & 82,00 & 137,09 & 67,18 & 59,40 & 73,67 & 24,02 & 73,00 \\
\hline Dias de faturamento comprometidos com contas a receber [dias] & 122,60 & 184,73 & 50,68 & 138,20 & 116,98 & $-15,35$ & 141,70 & 67,35 & $-52,47$ & 69,41 \\
\hline Indicador de desempenho financeiro [percentual] & 89,20 & 87,87 & $-1,49$ & 110,90 & 102,00 & $-8,03$ & 94,40 & 119,47 & 26,56 & 118,87 \\
\hline Despesa média anual por empregado [r\$/empreg.] & 41512,32 & 55393,73 & 33,44 & 18876,09 & 18278,98 & $-3,16$ & 25976,71 & 23071,71 & $-11,18$ & 22994,46 \\
\hline
\end{tabular}

Fonte: Elaboração própria da autora baseada em SNIS (2002 e 2007). 
Para 2007, a produtividade média do pessoal é maior para as empresas regionais, tanto ao incluir os funcionários terceirizados quanto se forem considerados só os funcionários próprios. Essas empresas também apresentam os maiores indicadores de despesa (total e de exploração), talvez pelo fato de possuírem uma estrutura tecnológica que exige maiores gastos em manutenção. Verifica-se aumento expressivo da despesa de exploração por economia não só por parte das empresas regionais $(99,46 \%)$, mas também por parte das empresas locais privadas $(36,71 \%)$.

O melhor desempenho financeiro foi atribuído para as públicas, em 2002, e para as locais privadas, em 2007. Para o ano de 2007, pode-se atribuir essa evidência ao fato das privadas possuírem uma gestão administrativa mais organizada e apresentarem meios de alavancar recursos que possibilitam maiores ganhos financeiros. A diferença nos indicadores, para esse tipo de prestador, entre 2002 e 2007, representou um aumento de 26,56 pontos percentuais, enquanto que para os outros dois tipos de prestadores verificou-se queda de 8,03 e 1,49 .

Com relação às tarifas médias praticadas, as públicas locais cobram as menores tarifas, também em ambos os anos, o que decorre, segundo Toneto e Saiani (2006), tanto de facilidades tributárias dessas empresas como da maior dificuldade política de se cobrar dos consumidores pela proximidade entre eleitor e gestor do serviço. É intrigante o fato das regionais registrarem o maior aumento de tarifa $(54,40 \%)$ uma vez que se valem de economias de escala e de densidade em suas ligações.

As locais públicas são aquelas que empregam mais pessoal próprio por 1000 ligações de água, o que pode significar uma baixa produtividade do pessoal empregado, já que são necessários muito mais empregados por ligação em relação ao quanto empregam os outros prestadores.

É interessante notar que o indicador dias de faturamento comprometidos com contas a receber diminuiu tanto para as locais públicas quanto para as locais privadas (mais acentuadamente para essas), mas aumentou para os prestadores regionais. Ou seja, as regionais, mesmo se valendo de economias de escala e densidade e sendo responsável pela maior cobertura do país, pratica tarifas médias mais altas e registrou a elevação de um indicador relacionado à inadimplência. Pelo fato de atingir todo tipo de região do país, possivelmente atuará em regiões de renda mais baixa que, por serem mais sensíveis a aumentos de tarifas, terão dificuldades de pagar suas contas em decorrência de qualquer aumento das mesmas. 
Por outro lado, pelo fato das locais privadas registrarem aumento de sua tarifa média praticada, mas uma queda do índice de dias de faturamento comprometidos com contas a receber, é possível que exista evidência da atuação desse tipo de prestador em regiões de renda mais elevada. Com relação ao terceiro grupo de indicadores temos as variáveis patrimoniais e de balanço, mostradas na tabela 3.8 a seguir;

Tabela 3.8 - Indicadores Patrimoniais e de Balanço

\begin{tabular}{|c|c|c|c|c|c|c|c|c|c|c|}
\hline \multirow[b]{3}{*}{ Indicadores } & \multicolumn{3}{|c|}{ Regional } & \multicolumn{3}{|c|}{ Local Público } & \multicolumn{3}{|c|}{ Local Privado } & \multirow[t]{2}{*}{ Emp. Priv. } \\
\hline & & & Variação & & & Variação & & & Variação & \\
\hline & 2002 & 2007 & $\begin{array}{c}2002-07 \\
(\%)\end{array}$ & 2002 & 2007 & $\begin{array}{c}\text { 2002-07 } \\
(\%)\end{array}$ & 2002 & 2007 & $\begin{array}{c}\text { 2002-07 } \\
(\%)\end{array}$ & 2007 \\
\hline Liquidez Corrente & 0,78 & 1,34 & 71,79 & 1,30 & 2,69 & 106,92 & 0,69 & 0,93 & 34,78 & 0,96 \\
\hline Liquidez Geral & 0,27 & 0,52 & 92,59 & 0,48 & 1,05 & 118,75 & 0,41 & 0,43 & 4,88 & 0,44 \\
\hline Grau de Endividamento & 0,57 & 0,56 & $-1,75$ & 0,64 & 0,75 & 17,19 & 0,49 & 1,23 & 151,02 & 1,20 \\
\hline Retorno sobre o Patrimônio Líquido & $-10,50$ & $-0,57$ & $-94,57$ & 9,40 & $-4,28$ & $-145,53$ & $-7,10$ & $-80,96$ & 1040,28 & $-76,97$ \\
\hline Margem Líquida com Depreciação & $-19,50$ & $-3,13$ & $-83,95$ & 2,00 & 3,39 & 69,50 & $-13,10$ & 451,49 & $-3546,49$ & 427,68 \\
\hline Margem Líquida sem Depreciação & $-6,70$ & 7,26 & $-208,36$ & 4,60 & 8,61 & 87,17 & 1,20 & 460,66 & 38288,33 & 436,78 \\
\hline Margem Operacional co & 16,90 & 5,96 & $-64,73$ & 11,10 & 8,39 & $-24,41$ & 15,20 & 18,48 & 21,58 & 17,73 \\
\hline Margem Operacional sem Depreciação & 29,70 & 16,35 & $-44,95$ & 15,70 & 13,61 & $-13,31$ & 29,50 & 27,64 & $-6,31$ & 26,83 \\
\hline Composição de Exigibilidades & 25,00 & 33,79 & 35,15 & 34,80 & 40,24 & 15,62 & 48,90 & 48,21 & $-1,41$ & 46,79 \\
\hline
\end{tabular}

Fonte: Elaboração própria da autora baseada em SNIS (2002 e 2007).

Chama atenção o fato que, para 2007, o maior grau de endividamento foi das privadas. Relativamente ao ano de 2002, houve um aumento de $151 \%$ nesse índice, que reflete a característica dessa entidade poder tomar empréstimos, por exemplo. Paralelamente, o retorno sobre o Patrimônio Líquido dessa empresa foi o mais negativo entre as três. Logo, a maior capacidade de se endividar e alavancar recursos estiveram aliados a um retorno negativo, devido em parte ao longo prazo de maturação dos investimentos e ao possível fato da recente atuação da iniciativa privada no setor ${ }^{30}$.

A análise dos dados também demonstra que a margem líquida, que pode ser definida, de uma maneira intuitiva, como o lucro líquido por unidade vendida, se apresentou negativa para as empresas regionais, apesar de ter ocorrido uma significativa melhora para 2007. Isso demonstra as dificuldades financeiras encontradas por tais empresas, uma vez que a margem operacional (lucro operacional por unidade de serviço vendida) foi positiva, apesar de

\footnotetext{
${ }^{30}$ O SNIS não possui informações de balanço das empresas locais de direito público, pelo fato dessas não divulgarem esses dados. São entidades de direito público os serviços municipais operados por órgão da administração direta centralizada - secretarias, departamentos ou outros órgãos municipais - ou por órgão também da administração direta, mas descentralizada, organizado na modalidade autarquias. São de direito privado as empresas públicas, as sociedades de economia mista e as empresas privadas. Logo, os valores da tabela referem-se a essas últimas entidades.
} 
decrescente. Essa relação fica mais clara quando se avaliam os dados das empresas privadas que apresentaram elevada margem líquida em 2007, o que pode ser decorrência de maiores ganhos financeiros. O próximo grupo de análise será o dos indicadores de qualidade entre os diferentes tipos de prestadores ${ }^{31}$, de acordo com tabela 3.9:

Tabela 3.9 - Indicadores de Qualidade

\begin{tabular}{|c|c|c|c|c|c|c|c|c|c|c|}
\hline \multirow[b]{2}{*}{ Indicador } & \multicolumn{3}{|c|}{ Regional } & \multicolumn{3}{|c|}{ Local Público } & \multicolumn{3}{|c|}{ Local Privado } & Empresa Privada \\
\hline & 2002 & 2007 & $\begin{array}{c}\text { Variação } \\
2002-07 \\
(\%) \\
\end{array}$ & 2002 & 2007 & $\begin{array}{c}\text { Variação } \\
\text { 2002-07 } \\
(\%) \\
\end{array}$ & 2002 & 2007 & $\begin{array}{c}\text { Variação } \\
\text { 2002-07 } \\
(\%) \\
\end{array}$ & 2007 \\
\hline $\begin{array}{l}\text { Duração Média dos Serviços } \\
\text { Executados [h/serviço] }\end{array}$ & 3,00 & 9,12 & 204,00 & 1,70 & 2,96 & 74,12 & 14,70 & 2,14 & $-85,44$ & 2,14 \\
\hline $\begin{array}{l}\text { Duração Média das Paralisações } \\
\text { [hs/paralisação] }\end{array}$ & - & 12,51 & - & 14,10 & 11,87 & $-15,82$ & 3,00 & 9,72 & 224,00 & 9,72 \\
\hline $\begin{array}{l}\text { Incidência de análises de cloro } \\
\text { residual fora do padrão [\%] }\end{array}$ & 4,00 & 2,68 & $-33,00$ & 1,70 & 4,51 & 165,29 & 2,20 & 0,25 & $-88,64$ & 0,25 \\
\hline $\begin{array}{l}\text { Incidência de análises de turbidez } \\
\text { fora do padrão [\%] }\end{array}$ & 5,00 & 24,88 & 397,60 & 1,80 & 3,77 & 109,44 & 1,00 & 0,23 & $-77,00$ & 0,23 \\
\hline $\begin{array}{l}\text { Incidência de análises de } \\
\text { coliformes fecais fora do padrão }\end{array}$ & 3,00 & - & - & 3,00 & - & & 0,00 & - & - & - \\
\hline $\begin{array}{l}\text { Extravasamentos de Esgoto por } \\
\text { Extensão de Rede [extrav/km] }\end{array}$ & 5,00 & 7,99 & 59,80 & 3,00 & 4,87 & 62,33 & 6,00 & 4,55 & $-24,17$ & 4,55 \\
\hline Indicador de qualidade & - & 0,9636 & - & - & 0,9610 & - & - & 0,9919 & - & 0,9909 \\
\hline
\end{tabular}

Fonte: Elaboração própria da autora baseada em SNIS (2007).

Mantém-se a tendência de que as regionais são piores na maioria dos indicadores de qualidade quando comparadas com as locais e essas, por sua vez, são piores que as privadas, nos dois anos. Talvez por causa do aumento da iniciativa privada no setor e, junto a isso, maiores investimentos em novas tecnologias. Quando se considera o extravasamento de esgoto por extensão de rede, incidência de análises de turbidez fora do padrão e incidência de análises de cloro residual fora do padrão é possível notar que somente a empresa privada apresentou queda nos indicadores entre 2002 e 2007. Nesse último ano, o valor registrado desses índices pelas regionais é bastante significativo. Por fim, apresenta-se o último grupo que é o dos indicadores de investimento pela tabela 3.9.1;

\footnotetext{
${ }^{31}$ Esses indicadores não são calculados para os prestadores regionais (e microrregionais). O valor obtido devese somente a uma prestadora, CAESB de Brasília.
} 
Tabela 3.9.1 - Indicadores de Investimento

\begin{tabular}{|c|c|c|c|c|c|c|c|c|c|c|}
\hline \multirow[t]{4}{*}{ Indicadores } & \multicolumn{3}{|c|}{ Regional } & \multicolumn{3}{|c|}{ Local Público } & \multicolumn{3}{|c|}{ Local Privado } & \multirow[t]{3}{*}{$\begin{array}{c}\text { Empresa } \\
\text { Privada } \\
\end{array}$} \\
\hline & & & Variação & & & Variação & & & Variação & \\
\hline & & & 2002-07 & & & 2002-07 & & & 2002-07 & \\
\hline & 2002 & 2007 & $(\%)$ & 2002 & 2007 & $(\%)$ & 2002 & 2007 & $(\%)$ & 2007 \\
\hline $\begin{array}{l}\text { Investimento total / população } \\
\text { dos municípios }(\mathrm{R} \$ / \mathrm{hab})\end{array}$ & 18,29 & 10,88 & $-40,50$ & 11,14 & 10,77 & $-3,34$ & 26,04 & 15,26 & $-41,40$ & 17,15 \\
\hline $\begin{array}{l}\text { Investimento água / } \\
\text { população municipal atendida } \\
\text { comágua ( } \mathrm{R} \$ / \mathrm{hab})\end{array}$ & 6,96 & 7,90 & 13,49 & 4,43 & 8,45 & 90,79 & 13,74 & 4,19 & $-69,48$ & 5,82 \\
\hline $\begin{array}{l}\text { Investimento esgoto / } \\
\text { população municipal atendida } \\
\text { com esgoto }(\mathrm{R} \$ / \mathrm{hab})\end{array}$ & 12,58 & 11,38 & $-9,51$ & 3,58 & 8,74 & 144,18 & 23,80 & 37,06 & 55,72 & 59,91 \\
\hline $\begin{array}{l}\text { Investimento total / número de } \\
\text { ligações }(A+E)-(R \$ / \text { lig })\end{array}$ & 73,96 & 63,98 & $-13,49$ & 28,18 & 58,00 & 105,83 & 95,51 & 78,20 & $-18,13$ & 79,32 \\
\hline $\begin{array}{l}\text { Recursos próprios / } \\
\text { investimento total }(\%)\end{array}$ & 0,48 & 0,48 & 0,38 & 0,87 & 0,84 & $-3,87$ & 0,29 & 0,83 & 186,37 & 0,73 \\
\hline $\begin{array}{l}\text { Recursos não onerosos / } \\
\text { investimento total (\%) }\end{array}$ & 0,18 & 0,23 & 28,49 & 0,05 & 0,10 & 101,89 & 0,00 & 0,00 & 0,00 & 0,010 \\
\hline $\begin{array}{l}\text { Recursos onerosos / } \\
\text { investimento total (\%) }\end{array}$ & 0,24 & 0,17 & $-30,20$ & 0,02 & 0,04 & 82,35 & 0,68 & 0,16 & $-75,97$ & 0,15 \\
\hline
\end{tabular}

Fonte: Elaboração própria da autora baseada em SNIS (2002 e 2007).

A tendência de que as privadas totais são as que mais investem, em montante, se manteve em 2007, mas o valor desse investimento apresentou queda para o investimento total e em água, com exceção do investimento em esgoto que registrou um aumento. De acordo com os autores Toneto e Saiani (2006), esse maior montante de investimentos pode ser decorrente de vários motivos, entre eles: piores indicadores de cobertura nos municípios em que as privadas obtiveram as concessões; concessões recentes com grande prazo para o vencimento e metas de investimento definidas nos contratos de concessão - assim, os maiores investimentos refletem o estágio das concessões e possibilidade de acesso a empréstimos para os quais as prestadoras públicas encontram-se impossibilitadas de acessar devido ao contingenciamento de crédito e ao tipo de organização à qual estão submetidas.

Em 2007, os investimentos com recursos próprios predominam nas públicas, mas o melhor indicador, em seguida, é o das privadas, com pouca diferença. Ao comparar com o valor de 2002, os prestadores privados apresentaram um crescimento de 186,37\%. Em relação aos recursos onerosos (financiamentos), vale destacar que as privadas também têm melhor índice, mas a diferença com as regionais é pequena. Nesse indicador, percebe-se que a empresa privada apresentou drástica queda, ou seja, os investimentos decorrentes de recursos onerosos diminuíram na composição dos investimentos totais das empresas. 


\section{4) Tendências Gerais do Setor.}

De acordo com Panorama da prestação de serviços no Brasil do Diagnóstico do SNIS de 2007 e a partir das estatísticas descritivas apresentadas em tópico anterior, é possível estabelecer algumas tendências gerais para o setor. Ao se fazer essas análises serão incluídos no conjunto dos prestadores, os microrregionais, que foram definidos anteriormente, mas que foram excluídos das estatísticas, pois existem poucos prestadores dessa categoria, fato que dificulta qualquer generalização.

Dentre os indicadores operacionais de água e esgoto, os valores do índice de atendimento médio da população total de 2007 para todo o conjunto de prestadores do SNIS foi por volta de $80,9 \%$ e, para esgoto, $42 \%$.

As Nações Unidas, por meio dos Objetivos de Desenvolvimento do Milênio (ODMs), estabeleceu metas de reduzir pela metade, até 2015, a proporção da população de 1990 sem acesso permanente à água potável segura e ao esgotamento sanitário. Estudo realizado, em 2007, pelo Programa de Modernização do Setor de Saneamento (PMSS), dimensionou tais metas e chegou aos seguintes números: $84,88 \%$ da população total de 2015 devem ter acesso a abastecimento de água e $60,57 \%$ da mesma população necessitam acesso aos serviços de esgoto. Esse estudo também calculou a probabilidade do país cumprir tais metas e atingiu o resultado de $71,39 \%$ de probabilidade para abastecimento de água e $29,81 \%$ para esgotamento sanitário.

De posse de tais informações, o Diagnóstico do SNIS (2007), a partir de uma análise da evolução do atendimento da população total desde o ano 2000, calculou o índice de atendimento nos dois anos, a média de crescimento anual, o índice para atender o ODM, o déficit em 2007 para atingir o ODM e a quantidade de vezes que deve ocorrer o mesmo crescimento médio apontado pelo SNIS. A tabela 3.9.2 a seguir sintetiza os resultados:

Tabela 3.9.2 - Estimativa para cumprimento das Metas do Objetivo de Desenvolvimento do Milênio

\begin{tabular}{c|c|c|c|c|c|c}
\hline Serviço & $\begin{array}{c}\text { Índice de } \\
\text { atendimento } \\
\mathbf{2 0 0 0}(\mathbf{\%})\end{array}$ & $\begin{array}{c}\text { Índice de } \\
\text { atendimento } \\
\mathbf{2 0 0 7}(\mathbf{\%})\end{array}$ & $\begin{array}{c}\text { Média de } \\
\text { crescimento } \\
\text { anual (\%) }\end{array}$ & $\begin{array}{c}\text { Índice para } \\
\text { atender o } \\
\text { ODM (\%) }\end{array}$ & $\begin{array}{c}\text { Déficit em 2007 } \\
\text { para atingir o } \\
\text { ODM (\%) }\end{array}$ & $\begin{array}{c}\text { Quantidade de vezes que deve } \\
\text { ocorrer o mesmo crescimento } \\
\text { médio apontado pelo SNIS }\end{array}$ \\
\hline Água & 77,80 & 80,90 & 0,44 & 84,88 & 3,98 & 9 \\
Esgoto & 37,10 & 42,00 & 0,70 & 69,71 & 27,71 & 40 \\
\hline
\end{tabular}

Fonte: Elaboração Própria da autora baseada em SNIS (2007). 
Uma dificuldade associada ao cumprimento das metas estabelecidas nos Objetivos de Desenvolvimento do Milênio pode ser explicada pela incompatibilidade entre as taxas de crescimento físico dos sistemas e os índices de atendimento dos serviços. É interessante notar ao analisar as informações referentes ao número de ligações ativas de água, volume de água produzido e extensão de rede, que houve um crescimento de 19\%, 13,5\% e 22,2\%, respectivamente, nos últimos quatro anos. Para os serviços de esgoto, o número de ligações ativas foi de $28,1 \%$ e da extensão da rede foi de $31,1 \%$.

Contudo, esse crescimento não se refletiu em aumento, na mesma proporção, de novos usuários ao sistema, o que produziria um maior nível de atendimento e acesso. O SNIS, em seu Diagnóstico (2007), enunciou que tal incoerência pode ser explicada pelo crescimento da demanda por novas ligações, sem que isso reflita um crescimento da população ou inclusão da mesma ao sistema de saneamento básico já construído. Portanto, deve-se atentar para os impactos dos investimentos sobre o crescimento dos índices de atendimento dos serviços da população total.

Em relação ao investimento, em 2003, o Brasil necessitava de R\$ 178 bilhões para universalizar os serviços de água e esgoto e fazer a reposição e manutenção dessa infraestrutura, de acordo com estudo do PMSS, "Dimensionamento da Necessidade de Investimentos para Universalização dos Serviços de Água e Esgotos no Brasil”. Esse valor, atualizado para dezembro de 2007, salta para R $\$ 268,8$ bilhões. A partir do cruzamento de dados do SNIS (período de 2001-2007) com os dados do estudo acima citado, obteve-se que o total já investido foi de $\mathrm{R} \$ 28,6$ bilhões, a média anual dos investimentos nos últimos sete anos foi de R \$ 4,1 bilhões, o saldo a investir para se alcançar a universalização é de R \$240,2 bilhões e, portanto, a quantidade de vezes que deve ocorrer o mesmo investimento médio para se alcançar a universalização é de 66 vezes.

Portanto, para que as metas sejam cumpridas até 2020, fica claro que essa média de investimentos anuais deve ser alterada. Caso contrário, dificuldades surgirão no cumprimento de tal objetivo.

\section{5) As funções-objetivo.}

De acordo com Parlatore (2000) as empresas públicas apresentam dificuldades associadas à otimização na distribuição de água em detrimento da produção. Logo, pode-se 
esperar que essas empresas apresentem piores índices de eficiência relativos a perdas de faturamento e distribuição. Portanto, os sinais esperados para esses dois índices, apresentados no quadro 3.1 para o grupo das privadas, são negativos, já que irão ter menores perdas nos mesmos com relação ao grupo das empresas públicas. Por outro lado, para a extensão da rede de água, que pode ser considerado um índice relativo ao aspecto da produção, espera-se um maior valor, e um coeficiente estimado positivo, para o grupo das privadas.

Em relação aos índices de atendimento urbano e total de água e esgoto, que se traduz numa medida de acesso aos serviços de saneamento básico, as públicas devem apresentar um maior índice, pelo fato de terem a responsabilidade de operar em regiões de renda inferior, geralmente não atrativas para o setor privado. Apesar dessa função social, os déficits de atendimento nas camadas com menor capacidade de pagamento e nas regiões mais pobres são cada vez mais persistentes. Ou seja, espera-se, nesse caso, sinal positivo para o parâmetro estimado das públicas.

Cabral, Lazzarini e Azevedo (2007) argumentam que empresas públicas apresentam uma política de substituição de trabalhadores pouco ágil, pelo fato de estarem submetidas a vários procedimentos burocráticos que envolvem processos de contratação e limitações fiscais. Segundo os mesmos, os contratos de trabalho do setor público são mais rígidos e respondem menos a objetivos de desempenho. Parlatore (2000), por sua vez, afirma que empresas públicas geralmente apresentam um excessivo aumento do quadro de pessoal. Essa realidade pode ser descrita nos indicadores de produtividade relativos ao número de empregados próprios por mil ligações de água ou mil ligações de água e esgoto. Quanto menor esse indicador menos inchado se encontrará o quadro de funcionários da empresa. Dessa forma, as empresas privadas se destacariam nesse indicador apresentando parâmetro negativo.

De acordo com Moreira (1998), a ineficiência operacional de empresas do setor público também é refletida nos altos custos com pessoal. O indicador que reflete essa afirmação é a participação da despesa de pessoal total na despesa de exploração e despesa média anual por empregado que deve indicador um valor positivo para o grupo das empresas públicas. Além desse indicador, existe uma tendência de que essas empresas também registrem uma maior despesa de exploração por economia e uma maior despesa com os serviços totais por $\mathrm{m}^{3}$ faturado, pelo fato de possuírem tecnologia defasada, dificuldades de manutenção técnica do sistema e trabalhadores menos produtivos e motivados. 
As empresas privadas por não estarem sujeitas a restrições fiscais e contingenciamento de crédito devem apresentar melhores indicadores financeiros no processo de alavancagem de recursos e um maior indicador relacionado ao grau de endividamento. As empresas privadas possivelmente devem apresentar também maiores tarifas, pelo fato de atuarem em regiões de renda mais elevada e por terem que cobrir custos operacionais que tornem rentável seus investimentos. As empresas públicas, por arcarem com elevados custos e possuírem uma função social, praticam um nível tarifário irrealista, ou seja, sujeito a outras finalidades ${ }^{32}$ e objetivos políticos. Aliado ao fato das públicas cobrarem menores tarifas, possivelmente o indicador dias de faturamento comprometido com contas a receber, que pode ser entendido como um indicador de inadimplência será maior para esse tipo de prestador.

Uma conseqüência dessa política tarifária é que a rentabilidade de tais empresas assim como a sustentabilidade econômico-financeira ficam comprometidas, fato que pode ser expresso pelos baixos níveis do indicador de balanço relativo à margem líquida das empresas.

Em relação aos indicadores de qualidade, é provável que as empresas privadas apresentem os melhores índices para extravasamento de esgoto por extensão de rede, incidência de análises de turbidez fora do padrão e incidência de análises de cloro residual fora do padrão. Contudo, segundo Cabral, Lazzarini e Azevedo (2007), o mesmo alto poder de incentivo do setor privado para reduzir custos pode fazê-lo negligenciar outras dimensões de desempenho tal como a qualidade.

Por fim, a tendência de que as privadas são as que mais efetivamente investem, na mesma linha de argumentação de que podem tomar maiores recursos de empréstimos e se endividar mais, se reflete no indicador de investimento total pelo número de ligações de água e esgoto e investimento total pela população total dos municípios. Isso indica sinais dos coeficientes positivos, para essas empresas.

Além disso, a parcela de investimento total realizado com recursos onerosos tende a ser maior para esse grupo, pois exibem maior capacidade de se endividar via obtenção de financiamentos. A parcela de investimento total realizado com recursos próprios também tende a ser positiva, uma vez que essas empresas geram receita num montante maior que as despesas, por meio de tarifas cada vez mais elevadas. Por fim, a parcela de investimento total realizado com recursos não onerosos (a fundo perdido) é nula ou bem pequena, já que não recebem esse tipo de recursos por se tratar do setor privado. Logo, com exceção desse último

\footnotetext{
${ }^{32}$ Tais como a assistencialista, por exemplo, que deve existir via programa de tarifa social pra população que não tem condições de arcar com as despesas dos serviços de água e esgoto, mas devem seguir normas regulatórias bem definidas.
} 
índice, que apresenta sinal negativo, todos os outros apresentam sinal positivo, para o grupo das empresas privadas.

Segue quadro ilustrativo 3.1 que traça as linhas gerais das funções-objetivo desses dois grupos de empresa, isto é, os sinais esperados para os coeficientes estimados da variável explicativa referente ao tipo de empresa que fornece serviços de saneamento e que atua em um determinado município:

Quadro 3.1 - As funções objetivo e sinais esperados dos coeficientes

\begin{tabular}{|c|c|c|c|}
\hline & Indicadores & $\begin{array}{c}\text { Privada } \\
\text { (sinal } \\
\text { esperado do } \\
\text { coeficiente) }\end{array}$ & $\begin{array}{c}\text { Pública } \\
\text { (sinal } \\
\text { esperado do } \\
\text { coeficiente) }\end{array}$ \\
\hline \multirow{7}{*}{ Operacionais } & Índice de Perdas de Faturamento [\%] & - & + \\
\hline & Índice de Perdas na Distribuição [\%] & - & + \\
\hline & Extensão rede água por ligação [m/ligação] & - & + \\
\hline & Índice de Atendimento Urbano Ag [\%] & - & + \\
\hline & Índice de Atendimento Total Ag [\%] & - & + \\
\hline & Índice de Atendimento Urbano Esg [\%] & - & + \\
\hline & Índice de Atendimento Total Esg [\%] & - & + \\
\hline \multirow{7}{*}{$\begin{array}{l}\text { Produtividade } \\
\text { Econômicos e } \\
\text { Administrativos }\end{array}$} & Despesa média anual/empregado [r\$/empreg.] & - & + \\
\hline & Participação Despesa Pessoal Total na Despesa de Exploração [\%] & - & + \\
\hline & Empregados próprios/mil ligações de água + esgoto [empreg./mil lig.] & - & + \\
\hline & Despesa total com serviço por $\mathrm{m}^{3}$ faturado $\left[\mathrm{R} \$ / \mathrm{m}^{3}\right]$ & - & + \\
\hline & Tarifa média praticada $\left[\mathrm{r} \$ / \mathrm{m}^{3}\right]$ & + & - \\
\hline & Dias de faturamento comprometidos com contas a receber [dias] & - & + \\
\hline & Indicador de desempenho financeiro [\%] & + & - \\
\hline \multirow{2}{*}{ Balanço } & Margem Líquida com Depreciação & + & - \\
\hline & Margem Líquida sem Depreciação & + & - \\
\hline \multirow{3}{*}{ Qualidade } & Incidência de análises de cloro residual fora do padrão [\%] & + & - \\
\hline & Incidência de análises de turbidez fora do padrão [\%] & + & - \\
\hline & Extravasamentos de Esgoto por Extensão de Rede [extrav/km] & + & - \\
\hline \multirow{5}{*}{ Investimento } & Investimento total / população dos municípios & + & - \\
\hline & Investimento total / número de ligações $(\mathrm{A}+\mathrm{E})$ & + & - \\
\hline & Recursos onerosos / investimento total (\%) & + & - \\
\hline & Recursos não onerosos / investimento total (\%) & - & + \\
\hline & Recursos próprios / investimento total (\%) & + & - \\
\hline
\end{tabular}

Fonte: Elaboração própria da autora. 


\section{Capítulo 4 - METODOLOGIA E VARIÁVEIS.}

\section{1) Modelo Econométrico.}

Após definidas as funções-objetivo, serão desenvolvidas análises econométricas para avaliar como a estrutura de governança (empresa privada, local pública, local privada e regional) afeta o desempenho das empresas de saneamento no Brasil. Os dados dessa análise são provenientes do SNIS e os índices elaborados pelo mesmo, descritos anteriormente, nas estatísticas descritivas, também são. Os dados utilizados são de corte transversal (crosssection), que se referem a uma amostra de municípios brasileiros (4.547) tomadas em um determinado ponto do tempo, qual seja o ano de 2007.

Segundo Wooldridge (2006), uma importante característica de dados em cross section é que não se pode assumir que foram obtidos por amostragem aleatória da população subjacente. Nesse estudo, os dados utilizados do SNIS têm a característica de ser autodeclaratório, ou seja, as empresas prestadoras de serviços de saneamento não são obrigadas por lei a enviaram suas informações de caráter institucional, administrativo, operacional, gerencial, econômico-financeiro e de qualidade sobre a prestação de serviços de água e esgoto $^{33}$ ao mesmo. Dessa forma, é possível que se tenha um problema de seleção amostral. Contudo, conforme autor acima, mesmo sem desconsiderar essa questão, ainda assim, a análise, tratada dentro do arcabouço de amostragem aleatória, proporciona importantes resultados e conclusões.

O método de estimação utilizado é o de Mínimos Quadrados Ordinários (MQO) que estabelece como variável dependente os diferentes indicadores de desempenho dos prestadores de serviços de saneamento, explicados pelas variáveis relativas às características municipais e ao tipo desse prestador atuante no município, de acordo com a seguinte forma funcional, linear nos parâmetros, definida a seguir:

$Y=\alpha+\beta X_{1}+\gamma X_{2}+\varepsilon$

\footnotetext{
33 “Não obstante a boa evolução do SNIS, ainda é necessário buscar o seu fortalecimento e estabilidade institucional, assim como estabelecer incentivos e obrigações para o fornecimento das informações por parte dos agentes do setor" (SNIS,2007).
} 
$Y$ : Vetor de características operacionais e de cobertura, características econômicas, financeiras e administrativas e características de qualidade e de balanço.

$\mathrm{X}_{1}$ : Vetor de características municipais (renda per capita, taxas de urbanização, tamanho da população e região de localização do município, por exemplo).

$\mathrm{X}_{2}$ : Vetor de variáveis dummies dos diferentes tipos de prestadores.

Gujarati (2006) mostra que esse método oferece, para uma dada amostra, estimativas únicas de $\hat{\alpha}, \hat{\beta}$ e $\hat{\gamma}$ que proporcionem o menor valor possível da soma dos quadrados dos resíduos, dado pela diferença entre o valor verdadeiro (populacional) e o valor estimado da variável dependente: $\sum\left(\hat{\varepsilon}_{i}\right)^{2}=\sum\left(y_{i}-\hat{y}_{i}\right)^{2}$.

O mesmo autor elenca algumas propriedades numéricas desses estimadores: são expressos unicamente em termos de quantidades observáveis, isto é, amostrais, e, portanto, podem ser calculados com facilidade, são estimadores pontuais do parâmetro populacional relevante e a linha de regressão amostral pode ser facilmente obtida, uma vez que se têm as estimativas de MQO. Contudo, a principal vantagem desse método é a possibilidade de se obter importantes propriedades estatísticas dos estimadores tais como inexistência de viés e consistência, entre outras. Nesse sentido, devem ser consideradas algumas premissas importantes em relação às variáveis explicativas $X_{i}$ e ao termo de erro que formam as chamadas hipóteses clássicas do modelo de regressão linear.

As quatro primeiras hipóteses desse modelo garantem que o estimador de MQO seja um parâmetro não viesado do parâmetro populacional (WOOLDRIDGE, 2006). A primeira hipótese define que o modelo populacional pode ser descrito pela equação um, ou seja, deve ser linear nos parâmetros $\alpha, \beta$ e $\gamma$ a serem estimados. A segunda hipótese estabelece que se deva ter uma amostra aleatória de $n$ observações do modelo populacional. A terceira premissa afirma que o valor médio do termo de erro é zero, dado quaisquer valores das variáveis independentes, em outras palavras, fatores não observados que não foram explícitos na forma funcional e que estão no termo de erro, não afetam de forma sistemática o valor médio de Y: $E\left(\varepsilon / X_{1}, X_{2}\right)=0$.

Por fim, a quarta hipótese estabelece que, na amostra, nenhuma das variáveis independentes deve ser constante e não podem ocorrer relações lineares exatas entre elas. Chama-se essa hipótese de colinearidade não perfeita. Sob essas quatro hipóteses, pode-se afirmar que os estimadores de MQO serão estimadores não-viesados do parâmetro populacional, isto é, o procedimento (aplicado em todas as amostras aleatórias possíveis) pelo 
qual as estimativas de MQO foram obtidas é não-viesado: na média, é possível dizer que o estimador acerta o verdadeiro valor populacional.

É importante que se especifique outras hipóteses que justificam alguns testes realizados, nesse estudo, tais como o teste de Jarque-Bera e o de Durbin Watson. A premissa da homocedasticidade enuncia que dado o valor de uma das variáveis dependentes, a variância do termo do erro deve ser a mesma para todas as observações: $\operatorname{var}\left(\varepsilon_{i} / X_{i}\right)=\sigma^{2}$. A outra hipótese diz respeito à inexistência de autocorrelação (ou correlação serial) entre os termos de erro. Dessa forma, dados quaisquer valores de $X, X_{i}$ e $X_{j}(\operatorname{com} i \neq j)$, a correlação entre quaisquer $\varepsilon_{\mathrm{i}}$ e $\varepsilon_{\mathrm{j}}(\mathrm{com} \mathrm{i} \neq \mathrm{j})$ é zero. Isso significa que dado $\mathrm{X}_{\mathrm{i}}$ os desvios de quaisquer dois valores de $\mathrm{Y}$ em relação a sua média não apresentam um padrão determinado. Não deve existir também, pela próxima hipótese, correlação entre o termo de erro $\varepsilon$ e a variável explicativa $\mathrm{X}$, pois isso impossibilita a avaliação de seus efeitos individuais sobre Y. Ou seja, presume-se que $\mathrm{X}$ e $\varepsilon$ devem exercer influências separadas e aditivas sobre Y. Logo, $\operatorname{cov}\left(u_{i}, X_{i}\right)=0$. As três últimas hipóteses são que o número de observações $n$ da estimação deve ser maior que o número de parâmetros a serem estimados, os valores de $\mathrm{X}$, numa determinada amostra, não devem ser os mesmos, ou seja, eles devem apresentar variação e o modelo de regressão deve estar especificado de forma correta.

Quando as premissas do modelo clássico de regressão linear forem atendidas pode-se considerar que o estimador de mínimos quadrados ordinários da classe dos estimadores lineares não tendenciosos tem variância mínima, ou seja, é um estimador eficiente. Essas propriedades estão contidas no teorema de Gauss-Markov (GUJARATI, 2006).

Se o objetivo da pesquisa em questão for a estimação pontual dos parâmetros dos modelos de regressão, o método de mínimos quadrados ordinários, que não faz qualquer pressuposição sobre a distribuição de probabilidade dos termos de erro, $\varepsilon_{i}$, será suficiente. Mas se dentro da finalidade do estudo busca-se inferência, então é preciso supor que os termos do erro seguem alguma distribuição de probabilidade (GUJARATI, 2006).

Nesse caso, utiliza-se a estatística de Jarque-Bera, baseada nas diferenças entre os coeficientes de assimetria e curtose da distribuição amostral da série e da distribuição teórica normal, que serve para testar a hipótese nula de que a amostra foi extraída de uma distribuição normal. Se os resíduos seguem essa distribuição, seu histograma deve ter a conhecida forma de sino e a estatística de Jarque-Bera não deve ser significativa.

Existem casos, entre as estimações, que não apresentam um valor desejável para esse teste, mesmo depois de incluir nas estimações, variáveis dummies de intercepto, cujo objetivo 
é corrigir os efeitos de possíveis outliers na amostra. Contudo, existem duas ressalvas em relação a essa constatação: a primeira é que, como a amostra é grande (varia em torno de 4.000 observações), assintoticamente poder-se-ia supor uma melhor aproximação da normalidade dos resíduos; a segunda refere-se ao fato de que, se realmente essa hipótese não puder ser verificada, ainda assim a relação de determinação mais fraca de desempenho entre os diferentes tipos de empresas pode ser considerada.

A hipótese de variância constante é violada quando o modelo exibe heterocedasticidade. De acordo com Hill, Griffiths e Judge (2000) esse problema ocorre com freqüência quando se trabalha com dados de corte transversal ${ }^{34}$, pelo fato de se ter dados sobre diversas unidades econômicas de vários tamanhos. Nesse caso, à medida que o tamanho da unidade econômica aumenta há maior incerteza associada aos resultados da variável dependente. As principais conseqüências da estimação de um modelo que apresenta heterocedasticidade é que o estimador de MQO não será mais o melhor estimador linear nãoviesado e os seus desvios padrão serão incorretos, invalidando os testes de hipóteses e os intervalos de confiança. Nesse trabalho, o cálculo do desvio padrão foi obtido via estimador de White, apropriado para grandes amostras, que ajuda a superar o problema de extração de inferências incorretas das estimativas de mínimos quadrados em presença de heterocedasticidade.

O teste de Durbin Watson, que mede o grau de correlação serial de ordem um, aponta para inexistência de autocorrelação, uma vez que os testes indicaram, em sua maioria, valores próximos de dois.

Por fim, os resultados das regressões são acompanhados de alguns testes que confirmam sua validade tais como R-quadrado, R-quadrado ajustado e estatística F. Na maior parte das estimações realizadas, o R-quadrado, chamado de grau de ajuste da regressão, situou-se acima de 50\% e abaixo de 99\%. Esse número mostra, o quanto da variação amostral da variável dependente é explicado pelos regressores. Mesmo que esse valor seja baixo, como ocorreu em algumas equações, não significa que os resultados não tenham utilidade, uma vez que esse valor pode indicar apenas que é difícil prever resultados individuais sobre a variável dependente com precisão. Quando se pretende fazer comparações entre dois modelos deve-se usar o R-quadrado ajustado: não se observa, nesse estudo, uma tendência entre os resultados em relação a essa medida. Por fim, as estatísticas $\mathrm{F}$ de todas as regressões consideraram que os coeficientes estimados, ao serem testados conjuntamente, não são iguais a zero.

\footnotetext{
${ }^{34}$ Apesar de não ser uma propriedade necessariamente restrita a esse tipo de dados.
} 
Após tais considerações sobre os testes, forma funcional e hipóteses que asseguram as propriedades estatísticas dos estimadores de mínimos quadrados ordinários, pode-se dizer que o intuito investigativo desse método é verificar se a estrutura de governança dos provedores de serviços de saneamento básico resulta em diferentes perfis de desempenho. Dado que os provedores possam ter diferentes funções-objetivo, de acordo com sua natureza jurídica, pretende-se verificar em quais indicadores de performance cada tipo de prestador possui melhor desempenho, a partir dos dados desagregados dos municípios.

Assim, é possível especificar diferentes tipos de indicadores como: desempenho financeiro (rentabilidade, cobertura de custos...), indicadores de atendimento social (grau de cobertura, nível de tarifas, entre outros), desempenho operacional ou eficiência técnica (perdas de faturamento, perdas na distribuição etc.), qualidade dos serviços (incidência de coliformes fecais e turbidez da água, por exemplo) e verificar se a natureza do prestador afeta o desempenho em determinado indicador.

Com isso, controlando-se por características municipais e outras variáveis dos provedores, pode-se observar se a literatura está condizente com as funções e atribuições estabelecidas para cada tipo de prestador e, dessa forma, analisar em qual campo de atuação um ou outro prestador é mais eficaz. Por fim, pretende-se observar e discutir algumas possíveis alternativas para as deficiências encontradas no setor e, conseqüentemente, para sua evolução.

\section{2) Descrição das variáveis.}

Dentre as variáveis utilizadas para a estimação dos índices de desempenho, são utilizados dois grupos de variáveis binárias: um dos grupos refere-se à região de localização geográfica do município. Por exemplo, a variável assume valor igual a um, se pertence à região Sul e zero, caso não pertença. Há, no modelo, cinco variáveis desse tipo: região Sul, Norte, Nordeste, Centro-Oeste e Sudeste. Essa última foi utilizada como grupo base nos testes pelo fato de que geralmente essa região apresenta os melhores indicadores para os mais diferentes tipos de variáveis.

O outro grupo refere-se ao tipo de prestador de serviço que atua no município em questão. De acordo com a classificação do SNIS, os prestadores de serviços de saneamento 
possuem duas classificações distintas entre si, mas ao mesmo tempo inter-relacionadas: a primeira delas é relativa à abrangência geográfica da empresa de saneamento e a segunda refere-se a sua natureza jurídica. Na primeira categoria, encontram-se três classificações: regional, microrregional e local.

As empresas regionais correspondem às antigas CESBs, Companhias Estaduais de Saneamento Básico, originadas na época do Planasa, que atendem a vários municípios ${ }^{35}$ e, geralmente, apresentam economias de escala e/ou de escopo decorrente de seu maior raio de atuação. Por outro lado, como discutido nos indicadores apresentados nas estatísticas descritivas, as empresas regionais, com exceção de alguns casos de sucesso ${ }^{36}$, encontram-se endividadas, atrasadas tecnologicamente e sem possibilidade de alavancar recursos para a realização de investimentos, em decorrência das restrições fiscais e limites de endividamento. A maior parte das empresas regionais, vinte e três, são sociedades de economia mista com administração pública.

As empresas locais, ao contrário, atendem somente um único município, no qual sua sede é localizada e, dentre elas, as naturezas jurídicas mais predominantes são autarquia e administração pública direta. A(s) vantagem(ens) das empresas locais é que elas estão mais próximas de reconhecer as necessidades da população referentes aos serviços de água e esgoto por sua atuação estar restrita aos limites municipais. Tais empresas também auferem economias de escala, decorrentes da própria característica econômica do setor de saneamento básico enquanto monopólio natural, mas num nível de produção inferior ao atingido pelas empresas regionais. Por fim, as empresas microrregionais estão entre esses dois extremos e atendem a dois ou mais municípios, contém algumas características da proximidade municipal e, ao mesmo tempo, são capazes de auferir um efeito de escala um pouco maior.

Nesse estudo, as empresas regionais e microrregionais, aquelas que atendem a mais de um município, foram agregadas no grupo das não locais e aquelas que atendem a um, e somente um, município, constituem o grupo das locais.

Portanto, a variável explicativa binária que a representa, denominada “local”, será um para os municípios que forem atendidos por empresas de saneamento de abrangência geográfica local, ou seja, atuantes somente naquele município e zero, para os municípios que forem atendidos por uma empresa não local, isto é, que atenda a mais de um município, podendo ser regional ou microrregional.

\footnotetext{
${ }^{35}$ De acordo com tabela 2.10, as 26 empresas regionais existentes no país atendem 3965 municípios com serviços de água e 1013 municípios com serviços de esgoto.

${ }^{36}$ Tais como a Sabesp, Cedae, Copasa, Sanepar e Corsan.
} 
local $=\left\{\begin{array}{c}1 \text { se empresa local } \\ 0 \text { se empresa não local }\end{array}\right.$

Cada uma dessas classificações de abrangência geográfica pode ser de seis tipos diferentes de natureza jurídica: sociedade de economia mista com administração pública, empresa pública, autarquia, administração pública direta, sociedade de economia mista com administração privada e empresa privada.

A classificação adotada, nesse trabalho, também agrupa essas diferentes naturezas jurídicas em dois grupos: empresas de saneamento públicas e privadas. Contudo, nessa classificação, a abrangência geográfica não é levada em consideração, ou seja, misturam-se em cada grupo empresas locais, regionais e microrregionais.

As empresas do grupo das privadas são aquelas literalmente classificadas pelo SNIS como empresa privada e aquelas do grupo das públicas contêm empresas que exibem as seguintes naturezas jurídicas: sociedade de economia mista com administração pública, empresa pública, autarquia, administração pública direta e sociedade de economia mista com administração privada ${ }^{37}$. Logo a variável binária, "privada_total”, nesse caso, é igual a um se o município for atendido por uma empresa classificada como privada e zero caso tiver seus serviços de saneamento oferecidos por uma empresa pública, segundo os critérios acima mencionados:

privada_total $=\left\{\begin{array}{l}1 \text { se empresa } \text { privada } \\ 0 \text { se empresa pública }\end{array}\right.$

De acordo com as várias interações possíveis entre abrangência do prestador e sua natureza jurídica foram criadas quatro categorias de grupos de prestadores de serviços de saneamento municipais para medir diferentes efeitos nas variáveis dependentes ${ }^{38}$ - segue esquema das quatro variáveis listadas a seguir:

\footnotetext{
${ }^{37}$ A SANEPAR, empresa regional cuja natureza jurídica é sociedade de economia mista com administração privada, apesar de possuir maior participação dos sócios privados na gestão dos negócios (o grupo Dominó comprou $39 \%$ do capital da empresa), não foi incluída no grupo das privadas, pelo fato de possuir capital público. Dessa forma, pretende-se deixar livre o grupo das empresas privadas de qualquer tipo de capital público.

${ }^{38}$ As variáveis listadas a seguir são binárias e igual a um se um determinado município é atendido pelo tipo de empresa considerado e zero, caso contrário.
} 


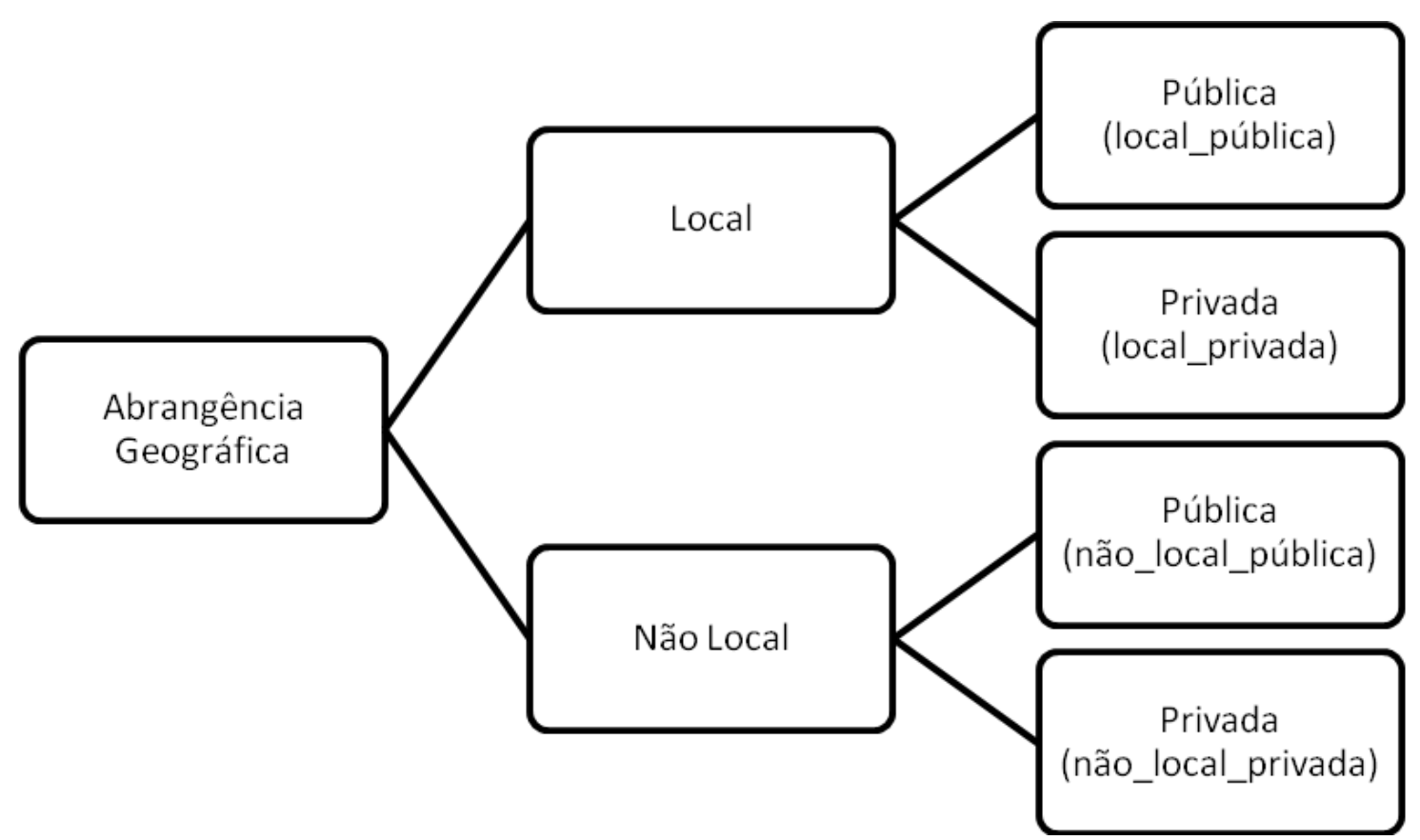

As quatro variáveis binárias obtidas da interação entre "local" e "privada_total": "não local privada", "não local pública", "local privada" e "local pública" são descritas e comentadas, com maiores detalhes, no apêndice. Para o objetivo das regressões econométricas basta diferenciar, em linhas gerais, umas das outras e saber as formas em que foram agregadas no modelo estimado. As variáveis apresentadas acima foram dispostas, em grande parte das estimações, de duas maneiras, detalhadas a seguir:

1. $Y=\alpha+(\ldots)+\beta_{4} n o+\beta_{5} n e+\beta_{6} s u+\beta_{7} c o+\gamma_{1}$ privada_total $+\gamma_{2}$ local_pública. Das quatro possíveis interações de dummies acima apresentadas agregaram-se as locais privadas com as não locais privadas (regionais e microrregionais privadas) formando $o$ grupo das privadas totais ("privada_total"). O objetivo dessa agregação é formar um grupo só das empresas privadas, independente se irão atuar em um ou mais de um município. Adicionando as locais públicas ("local_pública”) como a outra variável explicativa para compor o modelo, o grupo base de comparação passa a ser formado pelas regionais e microrregionais (não locais) públicas.

Nessa composição, pretende-se fazer a seguinte pergunta, ao analisar, por exemplo, o coeficiente $\gamma_{1}$ : empresas de gestão privada, quando comparadas com empresas que atendem a mais de um município e possuem gestão pública são melhores/piores que essas empresas em quais indicadores de desempenho, mantendo todos os outros fatores constantes? 
Assim, os coeficientes de cada uma das variáveis relacionadas ao tipo de empresas são comparados com o grupo das empresas regionais públicas e microrregionais públicas. Segue um esquema da estimação descrita acima:

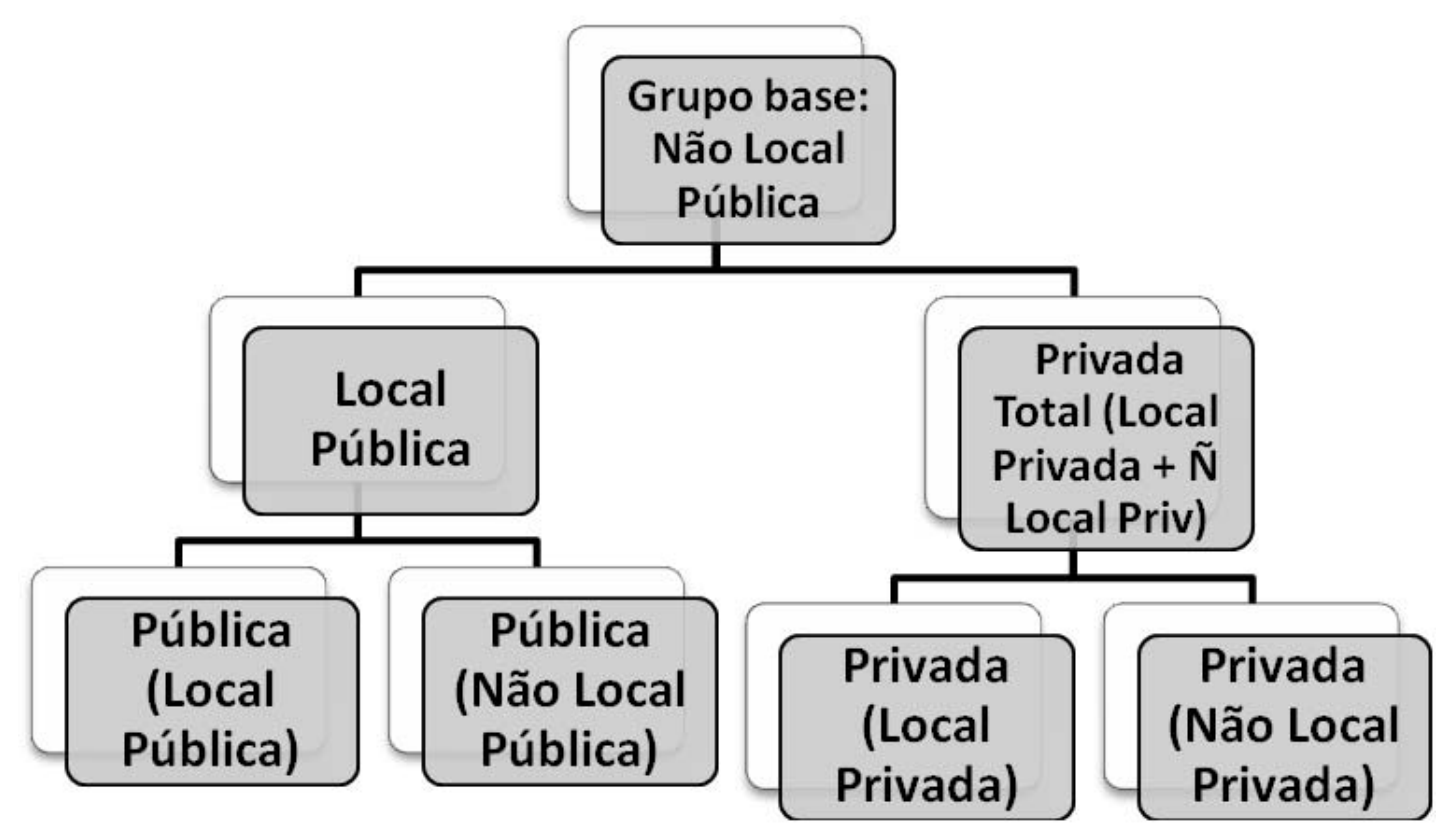

2. $Y=\alpha+(\ldots)+\beta_{4} n o+\beta_{5} n e+\beta_{6} s u+\beta_{7} c o+\gamma_{1}$ local_privada $+\gamma_{2}$ local _pública.

Nesse caso, verifica-se se uma empresa privada de abrangência local (“local_privada") tem diferenças significativas em relação ao grupo das regionais e das microrregionais, em sua forma original, isto é, grupo que contém todas as empresas que atendem a mais de um município, inclusive as empresas SANEATINS, CAJ, PROLAGOS E SATE, que são empresas privadas.

Nessa composição pretende-se fazer a seguinte pergunta, ao analisar, novamente, o coeficiente $\gamma_{1}$ : empresas privadas atendendo a um só município apresentam melhor desempenho em quais indicadores quando comparadas com as regionais e microrregionais dotadas da possível vantagem do efeito de escala? 


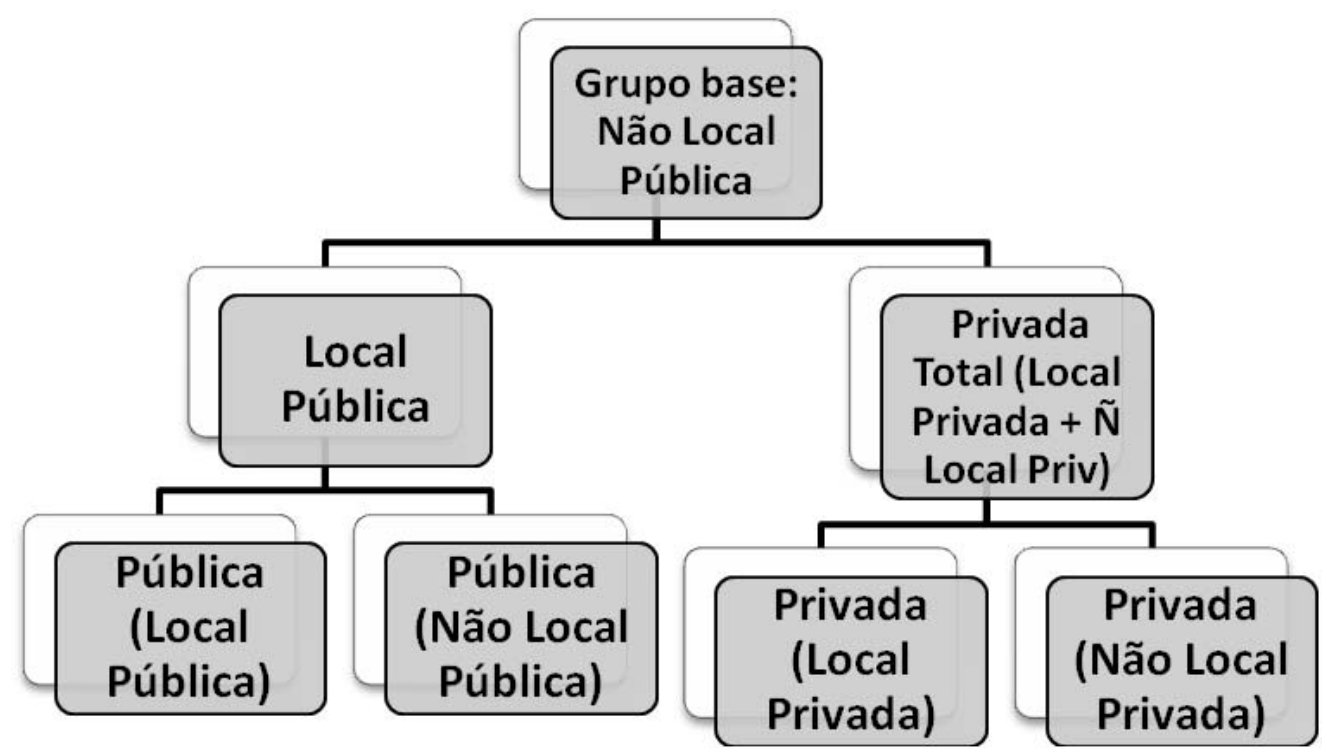

Além das variáveis binárias, as outras variáveis explicativas, de caráter quantitativo, são relacionadas às características municipais. A primeira delas é a "renda", que se refere à renda per capita municipal, calculada pela relação entre o PIB (Produto Interno Bruto ${ }^{39}$ ) de cada município e a população total do mesmo. A variável "urb" é a taxa de urbanização municipal, calculada como a razão entre a população urbana do município dividida pela sua população total. A variável "log_pop" foi obtida através do cálculo do logaritmo natural da população total do município. Essa transformação foi feita para linearizar o modelo e evitar possíveis correlações amostrais entre as variáveis. Em algumas regressões, foi utilizado o “idh" índice de desenvolvimento humano municipal, calculado pelo SNIS, que mede o desenvolvimento humano municipal, levando em consideração fatores como a distribuição de renda, de saúde e educação, desigualdades de oportunidades entre homens e mulheres, entre outras.

As variáveis dependentes utilizadas nas estimações são as referentes ao quadro 3.1, que apresenta as funções objetivo gerais pra cada tipo de empresa e indica os sinais esperados para cada tipo de variável analisada. A maior parte dessas variáveis são indicadores calculados pelo SNIS e as restantes construídas com informações primárias fornecidas pelo mesmo $^{40}$. Segue explicação da composição de cada variável, os detalhes de cada parcela constam no apêndice.

\footnotetext{
${ }^{39}$ Calculados a preços deflacionados e convertidos em dólares americanos.

${ }^{40}$ A partir da variável número treze, que irão compor o índice de qualidade, foram utilizadas as informações primárias do SNIS, os indicadores restantes já estão prontos e fornecidos pelo mesmo.
} 
Para os indicadores operacionais de água, tem-se as seguintes variáveis:

- Ind_atendimento_água $=\frac{\text { População_total_atendida_água }}{\text { Pop_total_municípios_atendidos_água }}$

- Ind_perdas_distribuição $=\frac{\text { Volume_água }- \text { Volume_água_consumido }}{\text { Volume_água }}$

- Ind_perdas_faturamento $=\frac{\text { Volume_água }- \text { Volume_água_faturado }}{\text { Volume_água }}$

- Densidade_economias_água $=\frac{\text { Qtdade_economias_ativas_água }}{\text { Qtdade_ligações_ativas_água }}$

Em relação ao grupo dos indicadores operacionais de esgoto, foram utilizadas as variáveis a seguir:

- Ind_atendimento_esgoto $=\frac{\text { Pop_total_atendida_esgoto }}{\text { Pop_total_municípios_atendido_água }}$

- Ind_coleta_esgoto $=\frac{\text { Volume_esgoto_coletado }}{\text { Volume_água_consumido-Volume_água_tratado_exportado }}$

- Ind_tratamento_esgoto $=\frac{\text { Volume_esgoto_tratado }}{\text { Volume_esgoto_coletado+Volume_esgoto_importado }}$

Para os indicadores econômicos, financeiros e administrativos, as variáveis são definidas a seguir:

- $\quad$ Tarifa_média_praticada $=\frac{\text { Recita_Operacional_Direta }(A+E)}{\text { Volume_Total_Faturado }(A+E)}$

- Despesa_total_serviços $=\frac{\text { Despesas_totais_serviços }}{\text { Volume_total_faturado }(A+E)}$ 
- Empregados_próprios_ligações $(A+E)=\frac{\text { Quantidade_total_empregados_próprios }}{\text { Quantidade_total_ligações_ativas }(A+E)}$

- Indicador_desempenho_financeiro $=\frac{\text { Receita_Operacional_Direta }}{\text { Despesas_totais_serviços }}$

O grupo dos indicadores de investimento é formado pelas seguintes variáveis:

- Investimento_ligação $=\frac{\text { Investimentos_totais }}{\text { Ligações_totais }(A+E)}$

- Investimento_habitante $=\frac{\text { Investimento_total }}{\text { População_total_municípios }}$

- Investimento_rec_onerosos $=\frac{\text { Inv_com_recursos_onerosos }}{\text { Investimento_total }}$

- Investimento_rec_não_onerosos $=\frac{\text { Inv_com_recursos_não_onerosos }}{\text { Investimento_total }}$

- Investimento_rec_próprios $=\frac{\text { Inv_com_recursos_próprios }}{\text { Investimento_total }}$

Por fim, o indicador de qualidade foi obtido da seguinte maneira: para cada um dos seguintes indicadores de qualidade, duração média dos serviços executados (I1), duração média das paralisações (I2), incidência de análises de cloro residual fora do padrão (I3), incidência de análises de turbidez fora do padrão (I4), incidência de análises de coliformes fecais fora do padrão (I5) e extravasamentos de esgoto por extensão de rede (I6), aplicou-se a fórmula:

- $I_{j}=\frac{x_{i}-x_{\min }}{X_{M A X}-X_{M I N}}, j=1 \ldots 5 \rightarrow$ Ind_qual $=\frac{I^{\prime} 1+I^{\prime} 2+I^{\prime} 3+I^{\prime} 4+I^{\prime} 5}{5}$

$\mathrm{O}$ valor do denominador refere-se à diferença entre o melhor e o pior valor, dentre todos os valores exibidos pelo indicador $\mathrm{j}$ em questão. O numerador refere-se ao cálculo de cada valor individual deduzido do valor mínimo do intervalo. Logo, quanto mais próximo o valor individual estiver do melhor valor do intervalor, irá se obter um indicador próximo a um: $x_{\max }-x_{\min }=X_{M A X}-X_{M I N}$. Para chegar ao indicador final de qualidade calcula-se a média para cada indicador transformado, $I^{\prime}{ }_{j}$. 
A seguir, nas tabelas 4.1 e 4.2, apresentam-se as estatísticas descritivas, para todos os valores observados da amostra, das variáveis explicativas e dependentes listadas acima.

Tabela 4.1 - Estatísticas Descritivas das Variáveis Explicativas do Modelo Econométrico

\begin{tabular}{cccccc}
\hline Variável & Obs & Média & Desvio-Padrão & Mínimo & Máximo \\
\hline urb & 4547 & 0,641 & 0,217 & 0,000 & 1,000 \\
renda & 4544 & 7,429 & 10,670 & 0,651 & 310,495 \\
idh & 4524 & 0,701 & 0,082 & 0,475 & 0,919 \\
log_pop & 4547 & 9,523 & 1,148 & 6,690 & 16,203 \\
no & 4547 & 0,070 & 0,256 & 0,000 & 1,000 \\
ne & 4547 & 0,338 & 0,473 & 0,000 & 1,000 \\
se & 4547 & 0,289 & 0,453 & 0,000 & 1,000 \\
su & 4547 & 0,210 & 0,407 & 0,000 & 1,000 \\
co & 4547 & 0,093 & 0,291 & 0,000 & 1,000 \\
privada_total & 4547 & 0,038 & 0,190 & 0,000 & 1,000 \\
local_privada & 4547 & 0,009 & 0,092 & 0,000 & 1,000 \\
local_publica & 4547 & 0,117 & 0,321 & 0,000 & 1,000 \\
local & 4547 & 0,126 & 0,331 & 0,000 & 1,000 \\
\hline
\end{tabular}

Fonte: Elaboração própria da autora baseada em SNIS (2007).

Tabela 4.2 - Estatísticas Descritivas das Variáveis Dependentes do Modelo Econométrico

\begin{tabular}{|c|c|c|c|c|c|}
\hline Variável & Obs & Média & Desvio-Padrão & Mínimo & Máximo \\
\hline Tarifa média praticada $\left(\mathrm{R} \$ / \mathrm{m}^{3}\right)$ & 4416 & 1,901 & 0,855 & 0,000 & 14,290 \\
\hline Despesa total com os serviços por $\mathrm{m}^{3}$ faturado $\left(\mathrm{R} \$ / \mathrm{m}^{3}\right)$ & 3797 & 3,363 & 47,619 & 0,010 & 2934,770 \\
\hline $\begin{array}{l}\text { Empregados próprios por mil ligações de água e esgoto } \\
\text { (empregados/ligação) }\end{array}$ & 4512 & 4,282 & 33,747 & 0,000 & 1500,000 \\
\hline $\begin{array}{l}\text { Densidade de economias de água por ligação } \\
\text { (economia/ligação) }\end{array}$ & 4509 & 1,082 & 0,138 & 1,000 & 3,850 \\
\hline Índice de desempenho financeiro (\%) & 3879 & 96,534 & 335,991 & 0,000 & 20733,480 \\
\hline Índice de atendimento total de água (\%) & 4516 & 64,987 & 25,106 & 0,000 & 100,000 \\
\hline Índice de perdas na distribuição (\%) & 4428 & 33,742 & 20,222 & $-360,500$ & 99,980 \\
\hline Índice de perdas no faturamento (\%) & 4429 & 26,219 & 23,335 & $-111,370$ & 100,000 \\
\hline $\begin{array}{l}\text { Índice de atendimento total de esgoto referido aos } \\
\text { municípios atendidos comágua (\%) }\end{array}$ & 1334 & 50,991 & 32,718 & 0,000 & 100,000 \\
\hline Índice de coleta de esgoto $(\%)$ & 1252 & 51,430 & 27,970 & 0,000 & 100,000 \\
\hline Índice de tratamento de esgoto $(\%)$ & 1280 & 72,320 & 41,600 & 0,000 & 100,000 \\
\hline $\begin{array}{l}\text { Investimento total por ligações de água e es goto } \\
\text { (R\$/ligação) }\end{array}$ & 3890 & 47,441 & 172,425 & 0,000 & 5065,191 \\
\hline Investimento total por habitante ( $\mathrm{R} \$ /$ habitante) & 4249 & 13,420 & 38,266 & 0,000 & 946,043 \\
\hline Investimentos realizados com recursos onerosos (R\$) & 3477 & 0,084 & 1,978 & 0,000 & 116,199 \\
\hline Investimentos realizados com recursos não onerosos (R\$) & 2485 & 0,098 & 0,273 & 0,000 & 1,000 \\
\hline Índice de qualidade $(\%)$ & 4097 & 0,964 & 0,062 & 0,000 & 1,000 \\
\hline
\end{tabular}

Fonte: Elaboração própria da autora baseada em SNIS (2007). 


\section{3) Resultados.}

As tabelas seguintes, na próxima seção, mostram os resultados das estimações para as variáveis apresentadas. A exposição dos resultados seguirá a mesma ordem de apresentação da média de cada conjunto de indicadores (operacionais de água, operacionais de esgoto, indicadores econômicos financeiros e administrativos, indicadores de investimento e de qualidade) para cada grupo de empresa: local pública, local privada e empresa privada ${ }^{41}$. Antes dos resultados das estimações, será apresentado gráfico da média de cada variável dependente selecionada, somente para o ano de 2007, separado por cada tipo de prestador e um teste de média para as mesmas variáveis em relação ao grupo das empresas privadas e públicas e ao grupo das locais e não locais a fim de verificar se a hipótese nula de que a média entre esses dois grupos é estatisticamente igual a zero, é rejeitada, ou seja, se tais grupos são diferentes sem considerar os controles representados pelas variáveis explicativas.

Geralmente, a regressão simples sobre uma constante e uma variável binária é uma maneira bastante objetiva de comparar a média de dois grupos. Para que o teste $t$ habitual seja válido, temos que assumir a manutenção da hipótese da homocedasticidade (WOOLDRIDGE, 2006). No teste de média, assim como nas regressões com as explicativas, o desvio-padrão dos coeficientes apresentados foi calculado utilizando a matriz robusta à heterocedasticidade. Segue, inicialmente, no gráfico 4.1 , as médias para cada indicador de cada grupo de prestadores:

41 Os indicadores contábeis não foram selecionados, pois não existe informação desagregada desses indicadores por município. 


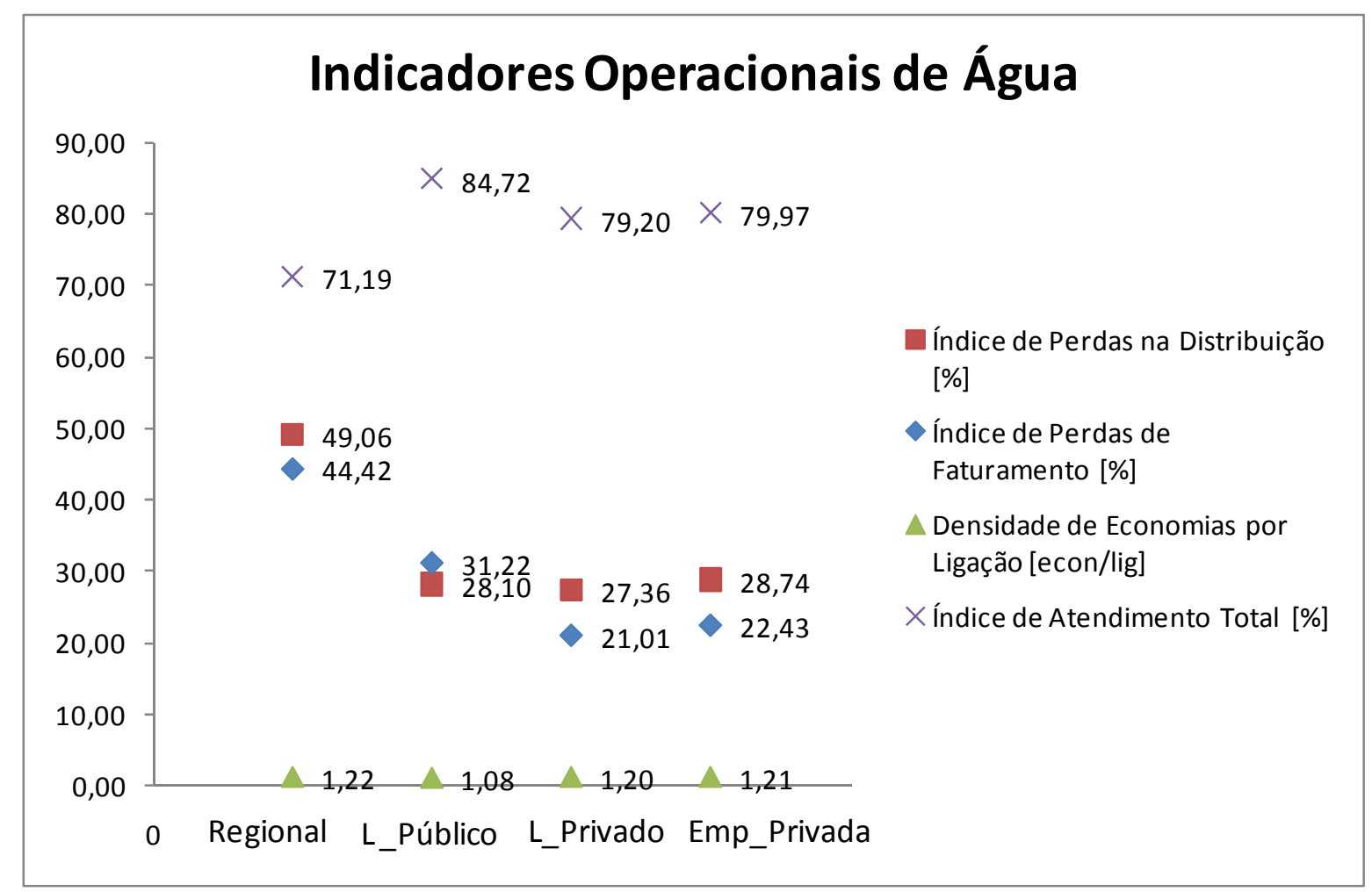

Fonte: Elaboração própria da autora baseada em SNIS 2007.

\section{Gráfico 4.1 - Média por tipo de prestador dos indicadores operacionais de água}

É possível observar que os maiores índices médios de perdas de faturamento e distribuição são das regionais. Por outro lado, esse grupo apresenta também o maior índice médio de densidade de economias por ligação. Em relação ao índice de atendimento total de água, destacam-se as locais públicas.

Na tabela 4.3, seguem os resultados dos testes de média que, a título de brevidade, apresentam-se somente os parâmetros da variável binária de interesse em questão:

Tabela 4.3 - Teste de média indicadores operacionais de água

\begin{tabular}{ccc}
\hline INDICADORES & privada total & local \\
\hline \multirow{2}{*}{ AT AGUA } & $10,048^{*}$ & $22,158^{*}$ \\
& $(1,528)$ & $(0,956)$ \\
ECO POR LIGAÇÃO & $0,042^{*}$ & 0,010 \\
& $(0,015)$ & $(0,008)$ \\
PERDAS FATURAMENTO & $-11,410^{*}$ & $4,883^{*}$ \\
& $(1,736)$ & $(1,107)$ \\
PERDAS DISTRIBUIÇÃO & $-11,391^{*}$ & $-6,497^{*}$ \\
& $(1,407)$ & $(0,831)$ \\
\hline
\end{tabular}

Fonte: Elaboração própria da autora baseada em SNIS 2007. 
Ao compararmos as médias dos dois grupos, vê-se que a média dos prestadores locais só não foi significativa para o indicador densidade de economias de água por ligação: ou seja, a média do grupo dos prestadores locais não é estatisticamente diferente da média do grupo dos regionais e microrregionais. A tabela 4.4 apresenta os resultados das estimações com os devidos controles ou variáveis explicativas:

Tabela 4.4 - Estimação I indicadores operacionais de água

\begin{tabular}{|c|c|c|c|c|}
\hline \multirow[t]{3}{*}{$\begin{array}{c}\mathbf{X}_{\mathbf{i}}=\text { Variáveis } \\
\text { Explicativas }\end{array}$} & \multicolumn{2}{|c|}{$\begin{array}{c}\mathrm{Y}_{1}=\text { Índice de } \\
\text { atendimento total de } \\
\text { água (\%) }\end{array}$} & \multicolumn{2}{|c|}{$\begin{array}{l}Y_{2}=\text { Índice de perdas } \\
\text { na distribuição (\%) }\end{array}$} \\
\hline & \multicolumn{4}{|c|}{ Coeficientes } \\
\hline & 1 & 2 & 3 & 4 \\
\hline renda & $\begin{array}{l}-0,007 \\
(0,013)\end{array}$ & $\begin{array}{l}-0,002 \\
(0,015)\end{array}$ & $\begin{array}{c}0,028 \\
(0,020)\end{array}$ & $\begin{array}{c}0,036^{* * *} \\
(0,019)\end{array}$ \\
\hline urb & $\begin{array}{r}96,444 * \\
(0,660)\end{array}$ & $\begin{array}{c}94,962 * \\
(0,723)\end{array}$ & $\begin{array}{l}7,255^{*} \\
(1,381)\end{array}$ & $\begin{array}{l}5,686^{*} \\
(1,106)\end{array}$ \\
\hline log_pop & $\begin{array}{l}-1,651^{*} \\
(0,116)\end{array}$ & $\begin{array}{l}-2,076^{*} \\
(0,137)\end{array}$ & $\begin{array}{l}3,184 * \\
(0,241)\end{array}$ & $\begin{array}{l}4,081^{*} \\
(0,200)\end{array}$ \\
\hline idh & & & & \\
\hline no & $\begin{array}{c}-11,964 * \\
(0,603)\end{array}$ & $\begin{array}{l}-8,612^{*} \\
(0,643)\end{array}$ & $\begin{array}{c}18,060^{*} \\
(1,516)\end{array}$ & $\begin{array}{l}4,537 * \\
(0,938)\end{array}$ \\
\hline ne & $\begin{array}{l}-5,251^{*} \\
(0,334)\end{array}$ & $\begin{array}{r}-4,503^{*} \\
(0,374)\end{array}$ & $\begin{array}{l}9,094 * \\
(0,683)\end{array}$ & $\begin{array}{l}5,341 * \\
(0,578)\end{array}$ \\
\hline $\mathrm{su}$ & $\begin{array}{l}-2,064^{*} \\
(0,335)\end{array}$ & $\begin{array}{r}-1,908^{*} \\
(0,369)\end{array}$ & $\begin{array}{l}1,985^{*} \\
(0,558)\end{array}$ & $\begin{array}{l}2,443^{*} \\
(0,510)\end{array}$ \\
\hline co & $\begin{array}{l}-3,150^{*} \\
(0,400)\end{array}$ & $\begin{array}{l}-2,608^{*} \\
(0,455)\end{array}$ & $\begin{array}{c}1,244 * * * \\
(0,748)\end{array}$ & $\begin{array}{c}0,565 \\
(0,646)\end{array}$ \\
\hline privada_total & $\begin{array}{l}10,324 * \\
(0,788)\end{array}$ & & $\begin{array}{c}-20,836^{*} \\
(1,662)\end{array}$ & \\
\hline local & & & & \\
\hline local_publica & $\begin{array}{l}9,160^{*} \\
(0,402)\end{array}$ & $\begin{array}{c}11,113^{*} \\
(0,480)\end{array}$ & $\begin{array}{r}-8,596^{*} \\
(0,806)\end{array}$ & $\begin{array}{l}-8,349^{*} \\
(0,668)\end{array}$ \\
\hline local_privada & & $\begin{array}{c}2,974 * * * \\
(1,676)\end{array}$ & & $\begin{array}{c}-10,442 * \\
(1,966)\end{array}$ \\
\hline $\mathrm{c}$ & $\begin{array}{r}21,255^{*} \\
(1,015) \\
\end{array}$ & $\begin{array}{r}25,723 * \\
(1,205) \\
\end{array}$ & $\begin{array}{c}-5,463^{*} \\
(2,030) \\
\end{array}$ & $\begin{array}{c}-14,248^{*} \\
(1,695) \\
\end{array}$ \\
\hline $\mathrm{R}^{2}$ & 0,9070 & 0,8797 & 0,3609 & 0,5913 \\
\hline $\mathrm{R}^{2}$ Ajustado & 0,9063 & 0,8791 & 0,3581 & 0,5888 \\
\hline Estatística F & 1323,27 & 1362,01 & 130,92 & 235,63 \\
\hline Probabilidade F & 0,0000 & 0,0000 & 0,0000 & 0,0000 \\
\hline Durbin-Watson & 1,9213 & 1,7332 & 2,0389 & 2,0562 \\
\hline Jarque-Bera & 8,1613 & 3,7592 & 4,9770 & 13,2007 \\
\hline Probabilidade JB & 0,0169 & 0,1526 & 0,0830 & 0,0014 \\
\hline
\end{tabular}


A primeira variável dependente do grupo dos indicadores operacionais de água é referente ao índice de atendimento total de água $\left(\mathbf{Y}_{1}\right)$. A primeira estimação contém a variável explicativa "privada_total", que representa todas as privadas, e "local_publica" que diz respeito às empresas locais que são públicas. O coeficiente dessa última variável foi significativo e positivo a $1 \%$, porém menor que o coeficiente da empresa privada: seu valor foi de 9,16 pontos percentuais, enquanto da empresa privada foi 10,32. Dessa forma, um município atendido por uma empresa local pública apresenta maior nível de atendimento total de água em relação ao município atendido por uma empresa do grupo das regionais e microrregionais (não locais) públicas. A mesma interpretação vale para o coeficiente das empresas privadas. Contudo, o teste de hipóteses para a diferença entre esses dois grupos não foi estatisticamente significante. Logo, não é possível supor que existiria uma tendência de que as empresas privadas seriam melhores que as locais públicas.

A regressão número dois, para a mesma variável dependente, considera o grupo base formado pelas regionais e microrregionais (não locais totais), sem distinção de natureza jurídica. A análise, nesse caso, se restringe à comparação entre locais (divididas entre locais públicas e locais privadas) e regionais/microrregionais.

Dessa forma, verifica-se que um município ser atendido por uma empresa local pública acrescenta mais ao índice de atendimento total de água do que se fosse atendido por uma não local independente da natureza jurídica. As locais privadas também aumentam o índice comparado com o mesmo grupo, contudo a um nível de $10 \%$ de significância, num valor de 2,97 pontos percentuais. Teste de hipótese para comparar esses dois tipos de locais mostrou que as locais públicas são melhores nesse indicador.

A próxima variável dependente a ser analisada é o índice de perdas na distribuição $\left(\mathbf{Y}_{2}\right)$. A equação número três mostra que a empresa do tipo "local_pública" apresenta queda em relação às regionais e microrregionais públicas. $\mathrm{O}$ mesmo ocorre com o grupo das empresas privadas, mas sua queda se dá numa magnitude maior que a queda das locais públicas. Esse hiato é significativo já que as privadas apresentam queda de 20,83 pontos percentuais frente à queda de 8,59 pontos percentuais das locais públicas. O teste de hipótese de igualdade entre esses dois coeficientes mostrou que as empresas privadas apresentam menores índices de perdas de distribuição que o grupo formado pelas locais públicas.

Por fim, a equação número quatro evidencia que, os municípios atendidos por empresas locais privadas apresentam maiores quedas em pontos percentuais, valor de 10,44, que os atendidos por não locais totais. Para as locais públicas essa queda em pontos 
percentuais é de 8,34 com relação ao mesmo grupo base. Dentre as locais, as locais privadas diferem do grupo das locais públicas, fato verificado por meio de teste de hipótese de igualdade entre seus coeficientes.

Ainda dentro dos indicadores operacionais, segue tabela 4.5, com as variáveis: índices de perdas no faturamento e densidade de economias de água por ligação.

Tabela 4.5 - Estimação II indicadores operacionais de água

\begin{tabular}{|c|c|c|c|c|}
\hline \multirow[t]{3}{*}{$\begin{array}{c}\mathbf{X}_{\mathbf{i}}=\text { Variáveis } \\
\text { Explicativas }\end{array}$} & \multicolumn{2}{|c|}{$\begin{array}{l}Y_{3}=\text { Índice de perdas } \\
\text { no faturamento (\%) }\end{array}$} & \multicolumn{2}{|c|}{$\begin{array}{c}\text { Y4 = Densidade de } \\
\text { economias de água } \\
\text { por ligação (eco/lig) }\end{array}$} \\
\hline & \multicolumn{4}{|c|}{ Coeficientes } \\
\hline & 5 & 6 & 7 & 8 \\
\hline renda & $\begin{array}{l}0,064 * \\
(0,022)\end{array}$ & $\begin{array}{c}0,058 * * \\
(0,023)\end{array}$ & $\begin{array}{c}5,56 \mathrm{E}-05 \\
(9,91 \mathrm{E}-05)\end{array}$ & $\begin{array}{c}6,48 \mathrm{E}-05 \\
(7,86 \mathrm{E}-05)\end{array}$ \\
\hline urb & $\begin{array}{l}10,415^{*} \\
(1,778)\end{array}$ & $\begin{array}{l}7,448^{*} \\
(1,804)\end{array}$ & $\begin{array}{c}0,006 \\
(0,004)\end{array}$ & $\begin{array}{c}0,010^{* *} \\
(0,004)\end{array}$ \\
\hline log_pop & $\begin{array}{l}3,609 * \\
(0,301)\end{array}$ & $\begin{array}{l}4,134^{*} \\
(0,306)\end{array}$ & $\begin{array}{l}0,023^{*} \\
(0,001)\end{array}$ & $\begin{array}{l}0,022^{*} \\
(0,001)\end{array}$ \\
\hline idh & & & & \\
\hline no & $\begin{array}{c}27,127^{*} \\
(1,706)\end{array}$ & $\begin{array}{r}16,702 * \\
(1,635)\end{array}$ & $\begin{array}{l}-0,028^{*} \\
(0,004)\end{array}$ & $\begin{array}{l}-0,012^{*} \\
(0,003)\end{array}$ \\
\hline ne & $\begin{array}{l}7,205^{*} \\
(0,816)\end{array}$ & $\begin{array}{l}6,980^{*} \\
(0,820)\end{array}$ & $\begin{array}{l}-0,041^{*} \\
(0,002)\end{array}$ & $\begin{array}{l}-0,041^{*} \\
(0,002)\end{array}$ \\
\hline $\mathrm{su}$ & $\begin{array}{c}0,088 \\
(0,728)\end{array}$ & $\begin{array}{c}0,257 \\
(0,730)\end{array}$ & $\begin{array}{l}0,035^{*} \\
(0,003)\end{array}$ & $\begin{array}{l}0,035^{*} \\
(0,002)\end{array}$ \\
\hline co & $\begin{array}{l}6,392 * \\
(0,846)\end{array}$ & $\begin{array}{l}5,760 * \\
(0,837)\end{array}$ & $\begin{array}{l}-0,002 \\
(0,003)\end{array}$ & $\begin{array}{l}-0,001 \\
(0,003)\end{array}$ \\
\hline privada_total & $\begin{array}{c}-26,617^{*} \\
(1,957)\end{array}$ & & $\begin{array}{l}0,042 * \\
(0,006)\end{array}$ & \\
\hline local & & & & \\
\hline local_publica & $\begin{array}{c}-2,154 * * \\
(0,911)\end{array}$ & $\begin{array}{l}-1,207 \\
(0,911)\end{array}$ & $\begin{array}{l}-0,029^{*} \\
(0,003)\end{array}$ & $\begin{array}{l}-0,031^{*} \\
(0,003)\end{array}$ \\
\hline local_privada & & $\begin{array}{r}-12,404^{*} \\
(2,819)\end{array}$ & & $\begin{array}{c}0,014 \\
(0,009)\end{array}$ \\
\hline $\mathrm{c}$ & $\begin{array}{r}-19,552^{*} \\
(2,471) \\
\end{array}$ & $\begin{array}{r}-22,784^{*} \\
(2,509) \\
\end{array}$ & $\begin{array}{l}0,839^{*} \\
(0,009)\end{array}$ & $\begin{array}{l}0,845^{*} \\
(0,007)\end{array}$ \\
\hline $\mathrm{R}^{2}$ & 0,2996 & 0,268499 & 0,8622 & 0,8600 \\
\hline $\mathrm{R}^{2}$ Ajustado & 0,2958 & 0,26451 & 0,8615 & 0,8593 \\
\hline Estatística F & 78,45 & 67,31 & 1219,55 & 1196,97 \\
\hline Probabilidade F & 0,0000 & 0,0000 & 0,0000 & 0,0000 \\
\hline Durbin-Watson & 2,0228 & 2,0201 & 1,9729 & 1,9798 \\
\hline Jarque-Bera & 6,7540 & 8,9335 & 1672,1860 & 1720,6920 \\
\hline Probabilidade JB & 0,0342 & 0,0115 & 0,0000 & 0,0000 \\
\hline
\end{tabular}


A variável índice de perdas de faturamento $\left(\mathbf{Y}_{3}\right)$ comporta-se de forma similar à variável anterior, mas com algumas ressalvas. Na estimação número cinco, as locais públicas também apresentam queda, contudo num valor pequeno (2,15 pontos percentuais) em relação ao valor das empresas privadas (26,61 pontos percentuais), cada qual comparada com o grupo base de comparação formado pelas não locais públicas. Essa diferença é estatisticamente significante entre esses dois grupos, ou seja, empresa privada registra menores perdas de faturamento que as locais públicas.

Ao estimar a equação número seis, verifica-se que a local privada também apresentou queda, porém a variável local pública não é importante para explicar esse índice ${ }^{42}$.

Por fim, a quarta e última variável escolhida desse grupo foi densidade de economias de água por ligação $\left(\mathbf{Y}_{4}\right)$. A equação número sete, indica que a variável empresa local pública, apresenta coeficiente de 0,029 densidade de economias de água por ligação enquanto o valor da empresa privada exibe valor de 0,042 para o mesmo índice. Entre elas, o teste de hipótese de igualdade entre os coeficientes mostrou que a empresa privada aumenta a densidade de economias de água por ligação mais que a empresa local pública.

Ao comparar as locais com as empresas regionais e microrregionais (não locais totais), estimação número oito, verifica-se que o coeficiente das empresas locais privadas não foi significativo em relação às regionais e microrregionais. Portanto, não é possível estabelecer relação entre elas, mas podemos verificar que a empresa local pública teve um menor número de densidade de economias de água por ligação num valor de 0,03 quando comparadas com as não locais totais.

Segue abaixo tabela resumo 4.6 construída após a análise de comparação de desempenho, de algumas possíveis tendências que podem existir entre os diversos tipos de empresas para o grupo de indicadores operacionais de água. As abreviações definidas se referem a "Não_Locais_Pub", as empresas regionais públicas e microrregionais públicas ou chamadas também de não locais públicas, "Não_Locais_T", grupo de todas as empresas regionais e microrregionais ou não locais totais, "L_Pub" correspondem às empresas locais públicas, "L_Priv" é relativa ao grupo das empresas locais privadas e "Priv_T" a todas as empresas privadas, independente de abrangência geográfica. $\mathrm{O}$ sinal de maior e menor corresponde à magnitude dos coeficientes estimados entre os que foram significantes e o ponto de interrogação significa que não foi possível estabelecer uma relação entre os três grupos de prestadores.

As empresas regionais públicas e microrregionais públicas (as não locais públicas), de acordo com os resultados das estimações, apresentam o pior desempenho em quase todos os

\footnotetext{
${ }^{42}$ Não aumenta e nem diminui o índice de perdas de faturamento, ou seja, não apresentou significância nem a 10,5 ou $1 \%$.
} 
indicadores da primeira coluna: maiores índices de perdas na distribuição e no faturamento e menor índice de densidade de economias de água por ligação. As empresas locais públicas apresentam melhor desempenho que esse grupo para o índice de atendimento total de água, mas não superam os valores apresentados pelas empresas privadas, nos indicadores restantes.

Tabela 4.6 - Relações entre os tipos de prestadores de serviços de saneamento

\begin{tabular}{lcc}
\hline Indicadores & Público x Privado & Regional x Local \\
\hline $\mathbf{Y}_{1}=$ At. total de água & $?$ & Loc_Pub $>$ Loc_Priv $>$ Não_Loc_T \\
\hline $\mathbf{Y}_{2}=$ Perdas distribuição & Priv_T $<$ Loc_Pub $<$ Não_Loc_Pub & Loc_Priv $<$ Loc_Pub $<$ Não_Loc_T \\
\hline $\mathbf{Y}_{3}=$ Perdas faturamento & Priv_T $<$ Loc_Pub $<$ Não_Loc_Pub & $?$ \\
\hline $\mathbf{Y}_{4}=$ Economias por ligação & Priv_T $>$ Loc_Pub $>$ Não_Loc_Pub & $?$ \\
\hline Fon & &
\end{tabular}

Fonte: Elaboração própria da autora.

O grupo dos indicadores operacionais de esgoto apresenta três variáveis: índice de atendimento total de esgoto, índice de coleta de esgoto e índice de tratamento de esgoto. $\mathrm{O}$ gráfico 4.2 mostra, da mesma forma que para o outro grupo, os valores médios de cada variável dependente, separados por tipo de prestador.

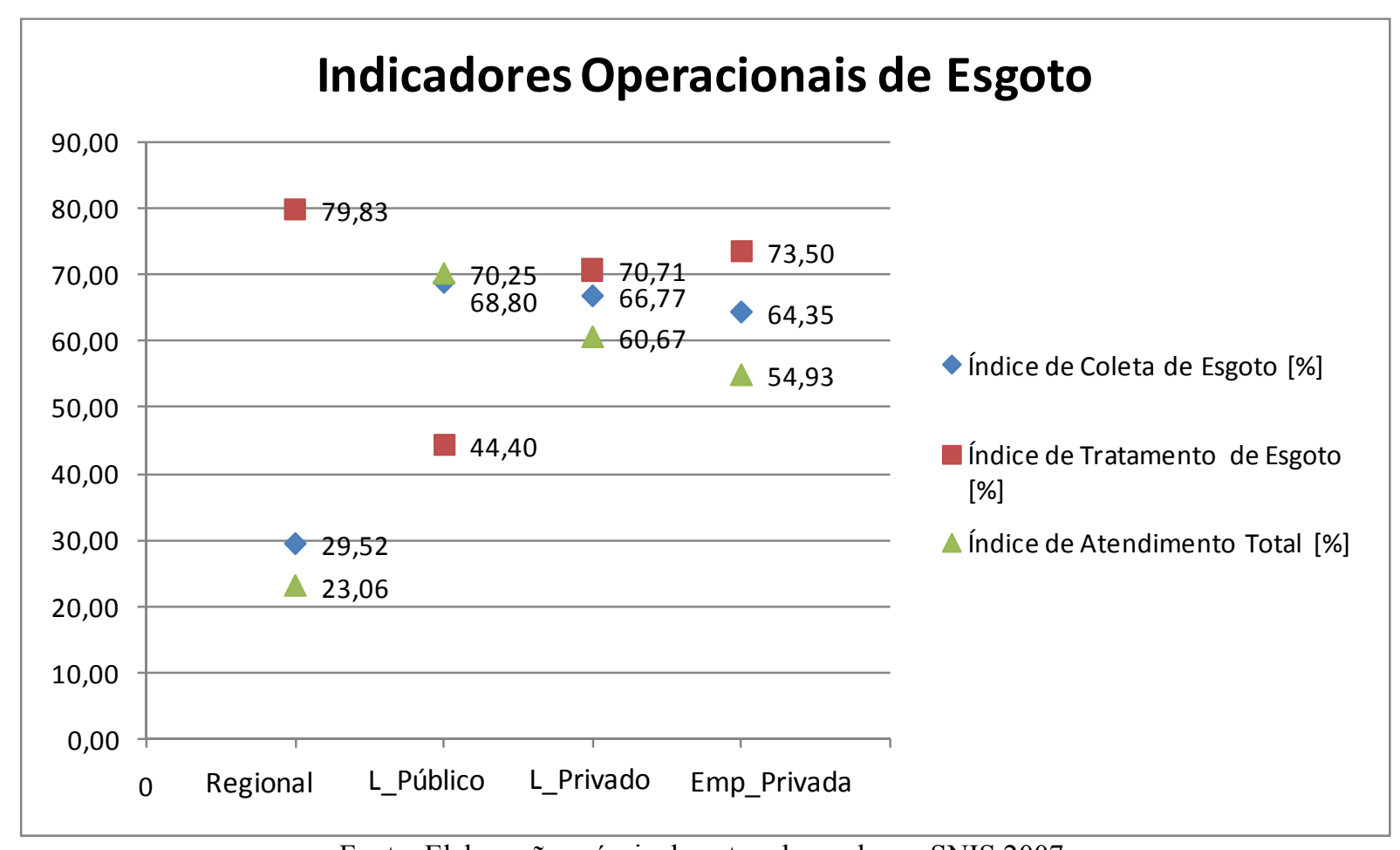

Fonte: Elaboração própria da autora baseada em SNIS 2007.

Gráfico 4.2 - Média por tipo de prestador dos indicadores operacionais de esgoto 
Conclui-se, nesse caso, que as regionais têm o melhor valor médio para o índice de tratamento de esgoto, porém apresenta o menor valor quando se trata do índice de coleta de esgoto. Novamente, para o índice total de atendimento de esgoto, as locais públicas apresentam a maior média entre os diversos grupos de prestadores. A tabela 4.7 indica os valores desses três indicadores para os testes de média;

Tabela 4.7 - Teste de média indicadores operacionais de esgoto

\begin{tabular}{ccc}
\hline INDICADORES & privada total & local \\
\hline \multirow{2}{*}{ AT ESGOTO } & $-4,687$ & $24,750^{*}$ \\
& $(5,496)$ & $(2,040)$ \\
COLETA & 5,898 & $20,881^{*}$ \\
& $(9,067)$ & $(2,131)$ \\
TRATAMENTO & 8,297 & $-34,839^{*}$ \\
& $(6,151)$ & $(2,847)$ \\
\hline Fonte: Elaboração própria da autora baseada em SNIS 2007.
\end{tabular}

Nesse teste, a média do grupo das empresas privadas não foi estatisticamente significante para nenhum dos indicadores: a média entre os grupos, sem nenhum controle, não difere do grupo das empresas públicas, em geral, para esses indicadores. Contudo, conforme se constatou graficamente, as empresas locais apresentam maior média para a coleta, ao passo que as regionais apresentam maior média para o índice de tratamento de esgoto. Tal fato foi confirmado no teste de média. A tabela 4.8 apresenta as estimações para o grupo dos indicadores operacionais de esgoto, mas com as variáveis explicativas; 
Tabela 4.8 - Estimação indicadores operacionais de esgoto

\begin{tabular}{|c|c|c|c|c|c|c|}
\hline \multirow[t]{3}{*}{$\begin{array}{l}\mathbf{X}_{\mathbf{i}}=\text { Variáveis } \\
\text { Explicativas }\end{array}$} & \multicolumn{2}{|c|}{$\begin{array}{c}Y_{5}=\text { Índice de } \\
\text { atendimento total de } \\
\text { esgoto }(\%)\end{array}$} & \multicolumn{2}{|c|}{$\begin{array}{c}\mathbf{Y}_{6}=\text { Índice de coleta } \\
\text { de esgoto }\end{array}$} & \multicolumn{2}{|c|}{$\begin{array}{c}Y_{7}=\text { Índice de } \\
\text { tratamento de } \\
\text { esgoto }(\%)\end{array}$} \\
\hline & \multicolumn{6}{|c|}{ Coeficientes } \\
\hline & 9 & 10 & 11 & 12 & 13 & 14 \\
\hline renda & $\begin{array}{c}0,038 \\
(0,051)\end{array}$ & $\begin{array}{c}0,050 \\
(0,037)\end{array}$ & $\begin{array}{c}0,026 \\
(0,046)\end{array}$ & $\begin{array}{c}0,032 \\
(0,045)\end{array}$ & $\begin{array}{c}0,058 \\
(0,069)\end{array}$ & $\begin{array}{c}0,224 \\
(0,196)\end{array}$ \\
\hline urb & $\begin{array}{r}23,073^{*} \\
(4,269)\end{array}$ & $\begin{array}{c}64,979 * \\
(3,198)\end{array}$ & $\begin{array}{r}22,635^{*} \\
(4,170)\end{array}$ & $\begin{array}{r}22,916^{*} \\
(3,749)\end{array}$ & $\begin{array}{r}20,374^{*} \\
(5,854)\end{array}$ & $\begin{array}{l}-10,380 \\
(19,416)\end{array}$ \\
\hline log_pop & $\begin{array}{l}-2,263^{*} \\
(0,541)\end{array}$ & $\begin{array}{l}-2,816^{*} \\
(0,413)\end{array}$ & $\begin{array}{l}-2,017^{*} \\
(0,512)\end{array}$ & $\begin{array}{l}-2,029 \\
(0,496)\end{array}$ & $\begin{array}{l}-8,254^{*} \\
(0,757)\end{array}$ & $\begin{array}{l}-1,183 \\
(2,138)\end{array}$ \\
\hline idh & & & & & & \\
\hline no & $\begin{array}{c}-41,895^{*} \\
(4,517)\end{array}$ & $\begin{array}{c}-56,075^{*} \\
(2,658)\end{array}$ & $\begin{array}{c}-44,662 * \\
(3,869)\end{array}$ & $\begin{array}{c}-41,770^{*} \\
(4,033)\end{array}$ & $\begin{array}{r}35,493 * \\
(6,632)\end{array}$ & $\begin{array}{l}47,152 * \\
(14,533)\end{array}$ \\
\hline ne & $\begin{array}{c}-29,257^{*} \\
(2,079)\end{array}$ & $\begin{array}{r}-41,765^{*} \\
(1,544)\end{array}$ & $\begin{array}{r}-30,724^{*} \\
(1,996)\end{array}$ & $\begin{array}{r}-30,716^{*} \\
(1,734)\end{array}$ & $\begin{array}{r}39,382 * \\
(2,676)\end{array}$ & $\begin{array}{l}57,348^{*} \\
(10,226)\end{array}$ \\
\hline $\mathrm{su}$ & $\begin{array}{c}-26,754^{*} \\
(1,891)\end{array}$ & $\begin{array}{c}-36,043^{*} \\
(1,435)\end{array}$ & $\begin{array}{c}-27,860 * \\
(1,789)\end{array}$ & $\begin{array}{c}-27,923^{*} \\
(1,540)\end{array}$ & $\begin{array}{r}34,924^{*} \\
(2,369)\end{array}$ & $\begin{array}{r}67,654^{*} \\
(5,968)\end{array}$ \\
\hline $\mathrm{co}$ & $\begin{array}{c}-35,563 * \\
(2,459)\end{array}$ & $\begin{array}{c}-45,301^{*} \\
(1,952)\end{array}$ & $\begin{array}{c}-36,330 * \\
(2,390)\end{array}$ & $\begin{array}{c}-36,455^{*} \\
(2,042)\end{array}$ & $\begin{array}{c}37,890^{*} \\
(3,233)\end{array}$ & $\begin{array}{r}64,799 * \\
(6,644)\end{array}$ \\
\hline privada_total & $\begin{array}{c}10,627 * * \\
(4,561)\end{array}$ & & $\begin{array}{c}11,239 * * \\
(4,508)\end{array}$ & & & \\
\hline local & & & & $\begin{array}{c}13,054^{*} \\
(1,408)\end{array}$ & $\begin{array}{c}-27,417^{*} \\
(2,160)\end{array}$ & \\
\hline local_publica & $\begin{array}{c}13,308^{*} \\
(1,566)\end{array}$ & $\begin{array}{c}16,607 * \\
(1,073)\end{array}$ & $\begin{array}{c}13,231^{*} \\
(1,470)\end{array}$ & & & \\
\hline local_pri & & $\begin{array}{c}14,564^{*} \\
(3,758)\end{array}$ & & & & $\begin{array}{c}26,499 * \\
(9,630)\end{array}$ \\
\hline $\mathrm{c}$ & $\begin{array}{c}67,663^{*} \\
(4,679) \\
\end{array}$ & $\begin{array}{c}43,936^{*} \\
(3,435) \\
\end{array}$ & $\begin{array}{c}66,188^{*} \\
(4,379) \\
\end{array}$ & $\begin{array}{c}66,088^{*} \\
(4,240) \\
\end{array}$ & $\begin{array}{c}132,088^{*} \\
(6,501)\end{array}$ & $\begin{array}{r}35,09 * * * \\
(17,905)\end{array}$ \\
\hline $\mathrm{R}^{2}$ & 0,5296 & 0,7750 & 0,57833 & 0,5780 & 0,4623 & 0,6175 \\
\hline $\mathrm{R}^{2}$ Ajustado & 0,5243 & 0,7716 & 0,57364 & 0,5736 & 0,4564 & 0,5932 \\
\hline Estatística F & 101,07 & 222,39 & 123,14 & 132,53 & 78,18 & 25,47 \\
\hline Probabilidade F & 0,000 & 0,0000 & 0,0000 & 0,0000 & 0,0000 & 0,0000 \\
\hline Durbin-Watson & 2,2323 & 1,5797 & 2,11366 & 2,1033 & 2,3115 & 1,9594 \\
\hline Jarque-Bera & 0,6557 & 1,9977 & 1,14505 & 0,7473 & 60,9340 & 31,6002 \\
\hline Probabilidade JB & 0,7205 & 0,3683 & 0,56410 & 0,6882 & 0,0000 & 0,0000 \\
\hline
\end{tabular}

Fonte: Elaboração própria da autora baseada em SNIS (2007).

Desvios-padrão robustos à heterocedasticidade em parênteses.

Coeficientes significantes a $* 1 \%$, a $* * 5 \%$ e a $* * * 10 \%$. 
A estimação número nove que possui como variável dependente o índice de atendimento total de esgoto $\left(\mathbf{Y}_{5}\right)$ apresenta coeficiente positivo e significativo a $10 \%$ para a variável "privada_total" e coeficiente significativo a $1 \%$ para a variável "local pública". Portanto, um município ser atendido por uma empresa prestadora de serviços de saneamento de abrangência local e natureza jurídica pública aumenta o índice de atendimento total de esgoto, num valor de 13,30 pontos percentuais comparativamente ao município atendido por uma empresa regional ou microrregional pública. Se a empresa for privada esse valor vai para 10,62 pontos percentuais em relação ao mesmo grupo das não locais públicas. Entre os grupos, empresas privadas e locais públicas, essas últimas são melhores que as privadas, de acordo com teste de hipóteses realizado, pois aumentam mais o índice total de atendimento de esgoto.

A equação número dez revela, ao comparar as locais com as regionais, que as locais públicas impactam mais o nível de atendimento total de esgoto (aumentou esse índice em 16,60 pontos percentuais) do que as não locais totais. As locais privadas, também aumentam o mesmo num valor de 14,56 pontos percentuais, com relação ao mesmo grupo base. Contudo as locais privadas não apresentaram diferença em relação àquele grupo ao se realizar o teste de hipóteses para a igualdade de ambos.

A variável dependente índice de coleta de esgoto ( $\left.\mathbf{Y}_{6}\right)$, na equação onze, demonstra também um predomínio das empresas locais públicas, aumento de 13,23 pontos percentuais no índice de coleta de esgoto, em relação às não locais públicas. Já as empresas privadas registram aumento de 11,23 no mesmo índice ao serem comparadas com o mesmo grupo base. Porém, as empresas locais públicas não são melhores ou piores que as privadas mas, ambas, por sua vez, são melhores que as regionais e microrregionais públicas.

Ao analisar a equação doze observa-se que o grupo das locais, formado pelas locais públicas e locais privadas, coleta mais que as regionais, pois o coeficiente dessa variável foi significativo a $1 \%$ e registra um aumento de 13,05 pontos percentuais em relação às empresas regionais e microrregionais totais. Porém, quando se considera o índice de tratamento de esgoto $\left(\mathbf{Y}_{7}\right)$, equação treze, são as regionais que tratam mais do que as locais, ou seja, o coeficiente das locais é significativo a $1 \%$ e negativo, o que mostra que o município ser atendido por uma empresa local pública gera uma queda de 27,41 pontos percentuais no índice de tratamento de esgoto. Por fim, a equação catorze mostra que ser empresa local privada aumenta o índice em relação a ser local pública. Nessa estimação, as regionais e 
microrregionais foram retiradas da amostra a fim de que somente fosse feita a comparação entre as empresas locais. Os resultados comentados são resumidos na tabela 4.9 seguinte:

Tabela 4.9 - Relações entre os tipos de prestadores de serviços de saneamento

\begin{tabular}{lcc}
\hline Indicadores & Público $x$ Privado & Regional $x$ Local \\
\hline $\mathbf{Y}_{5}=$ At. total de esgoto & Loc_Pub $>$ Priv_T $>$ Não_Loc_Pub & ? \\
\hline $\mathbf{Y}_{6}=$ Coleta esgoto & $?$ & Locais $>$ Não_Loc_T \\
\hline $\mathbf{Y}_{7}=$ Tratamento esgoto & Priv_T $>$ Loc_Pub & $\begin{array}{l}\text { Não_Loc_T }>\text { Locais; } \\
\text { Loc_Priv }>\text { Loc_Pub }\end{array}$ \\
\hline
\end{tabular}

Fonte: Elaboração própria da autora.

O gráfico 4.3 a seguir refere-se à média das variáveis do grupo dos indicadores econômicos, financeiros e administrativos por tipo de prestador:

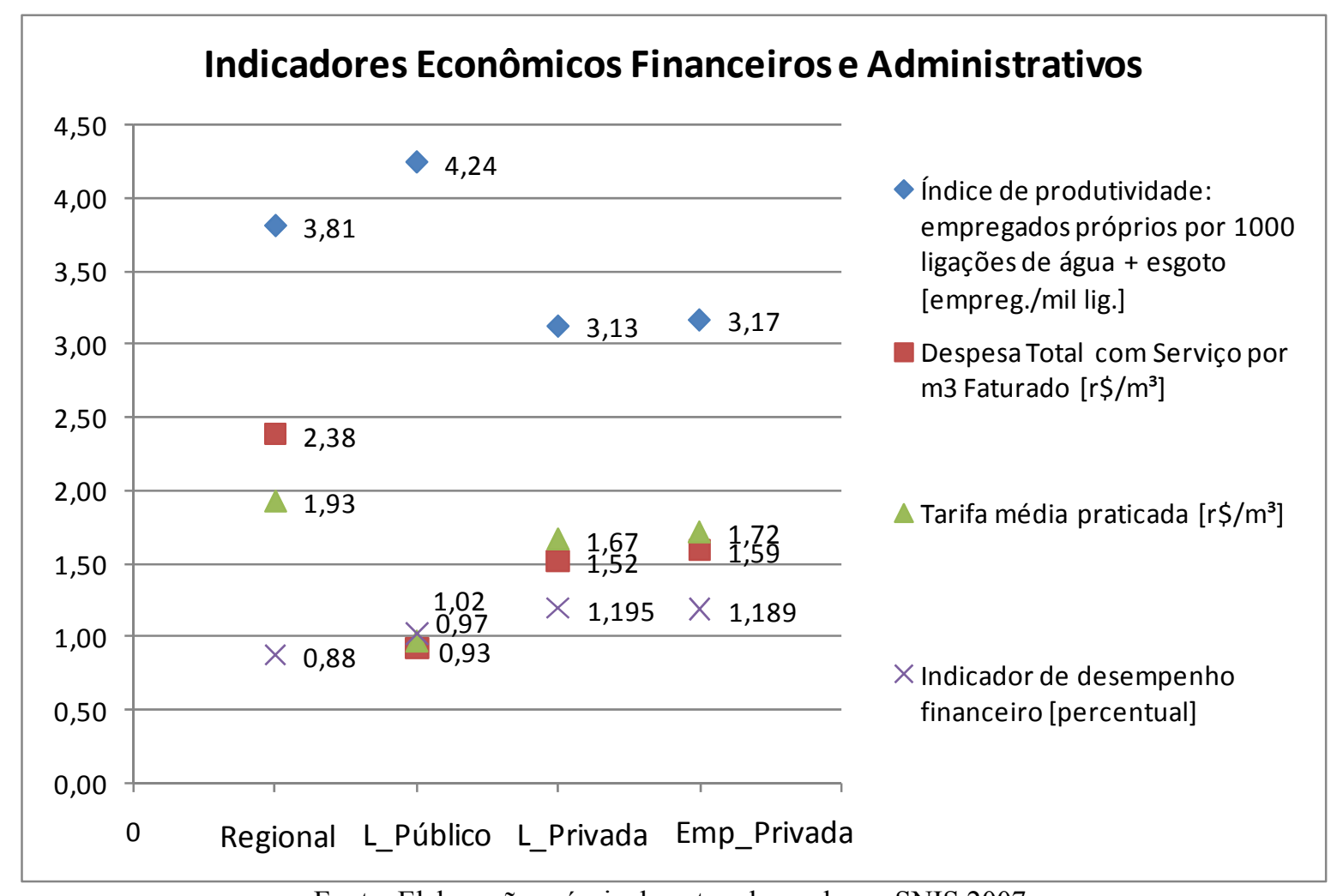

Fonte: Elaboração própria da autora baseada em SNIS 2007.

Gráfico 4.3 - Média por tipo de prestador dos indicadores econômicos, financeiros e administrativos

As empresas locais públicas novamente se destacam para o índice de produtividade (maior valor) e para o índice de despesa total com o serviço por $\mathrm{m}^{3}$ faturado (menor valor). Já 
o grupo que apresenta maior tarifa, na média, é o das regionais e a menor é o das locais públicas. O melhor valor médio do indicador de desempenho financeiro é o das empresas privadas, com destaque para as locais privadas. Segue o teste de média, tabela 4.9.1, para as variáveis desse grupo:

Tabela 4.9.1 - Teste de média indicadores econômicos, financeiros e administrativos

\begin{tabular}{ccc}
\hline INDICADORES & priv total & local \\
\hline \multirow{2}{*}{ EMPREGADOS POR LIG } & $-0,133$ & $-0,138$ \\
& $(0,536)$ & $(0,620)$ \\
DESPESA COM SERV & $-1.517^{* *}$ & $-2,737^{*}$ \\
& $(0,810)$ & $(0,889)$ \\
TARIFA & 0,040 & $-0,988^{*}$ \\
& $(0,0452)$ & $(0,028)$ \\
\multirow{2}{*}{ DESEMPENHO FINANCEIRO } & $10,461^{* * *}$ & 7,762 \\
& $(6,293)$ & $(6,564)$ \\
\hline
\end{tabular}

Fonte: Elaboração própria da autora baseada em SNIS 2007.

A variável referente a empregados próprios por mil ligações de água e esgoto, não foi significativa para nenhum dos grupos. As despesas com os serviços por $\mathrm{m}^{3}$ faturado foi significativa, mas as locais apresentam maior queda. As locais apresentaram menor tarifa e as privadas melhor indicador de desempenho financeiro. Seguem as estimações, na tabela 4.9.2, em partes, paras as variáveis desse grupo; 
Tabela 4.9.2 - Estimação I indicadores econômicos, administrativos e financeiros

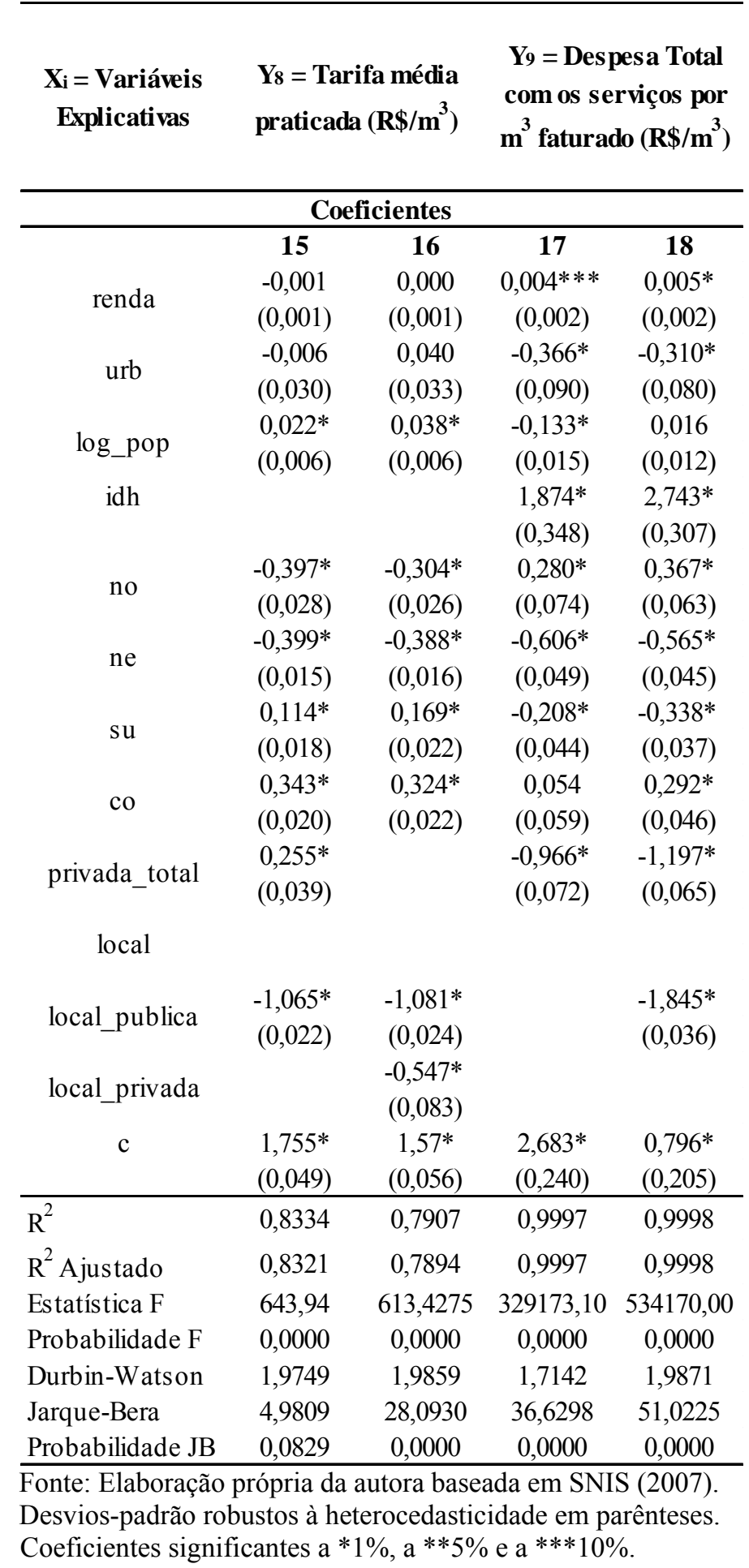


A variável tarifa média praticada $\left(\mathbf{Y}_{\mathbf{8}}\right)$, na estimação quinze, apresentou coeficiente positivo e significativo a $1 \%$ para as empresas privadas, no valor de $\mathrm{R} \$ 0,255 / \mathrm{m}^{3}$ em relação ao grupo das regionais e microrregionais públicas, enquanto a local pública apresentou coeficiente significativo também a $1 \%$, porém com sinal negativo, em comparação com o mesmo grupo. As empresas privadas também apresentaram maiores tarifas que as locais públicas.

Na equação número dezesseis, as locais públicas apresentam uma queda de tarifa com relação às regionais e microrregionais, coeficiente significativo a $1 \%$ no valor de $\mathrm{R} \$ 1,08 / \mathrm{m}^{3}$, as locais privadas também, contudo, num valor menor em magnitude, $\mathrm{R} \$ 0,54 / \mathrm{m}^{3}$. Por meio de teste de hipóteses de igualdade entre os coeficientes, foi constatado que as tarifas das locais privadas são maiores que aquelas das locais públicas.

A variável despesa total com os serviços por $\mathbf{m}^{3}$ faturado $\left(\mathbf{Y}_{9}\right)$ é um indicador de produtividade, ou seja, quanto maior a despesa total com os serviços pior o desempenho em termos de produtividade do prestador, mesmo que essa análise não esteja associada à verificação da qualidade do serviço. Percebe-se que o coeficiente das empresas privadas apresenta queda quando comparado com o restante das empresas (estimação número dezessete), de $\mathrm{R} \$ 0,96 / \mathrm{m}^{3}$, significativo a $1 \%$. Contudo (na equação dezoito) a introdução da variável local pública também mostra um coeficiente negativo e significativo a $1 \%$, num valor maior, de $\mathrm{R} \$ 1,84 / \mathrm{m}^{3}$, que o coeficiente das empresas privadas, $\mathrm{R} \$ 1,19 / \mathrm{m}^{3}$, quando comparado com as regionais públicas e microrregionais públicas. Quando se compara esses dois grupos (locais públicas e empresas privadas) não é possível afirmar qual dentre eles é mais produtivo.

A análise da variável relativa à produtividade referente a empregados próprios por mil ligações de água e esgoto e índice de desempenho financeiro é apresentada na tabela 4.9.3 abaixo; 
Tabela 4.9.3 - Estimação II indicadores econômicos, administrativos e financeiros

\begin{tabular}{|c|c|c|c|c|}
\hline \multirow[t]{3}{*}{$\begin{array}{c}\mathbf{X}_{\mathbf{i}}=\text { Variáveis } \\
\text { Explicativas }\end{array}$} & \multicolumn{2}{|c|}{$\begin{array}{c}\text { Y10 = Empregados } \\
\text { próprios por mil } \\
\text { ligações de água e } \\
\text { esgoto (empreg/mil } \\
\text { lig) }\end{array}$} & \multicolumn{2}{|c|}{$\begin{array}{c}\text { Y11 = Índice de } \\
\text { desempenho } \\
\text { financeiro (\% ) }\end{array}$} \\
\hline & \multicolumn{2}{|c|}{ Coeficientes } & & \\
\hline & 19 & 20 & 21 & 22 \\
\hline renda & $\begin{array}{c}0,005 * * \\
(0,002)\end{array}$ & $\begin{array}{c}0,003 \\
(0,002)\end{array}$ & $\begin{array}{l}-0,178 * \\
(0,050)\end{array}$ & $\begin{array}{l}-0,190 * \\
(0,056)\end{array}$ \\
\hline urb & $\begin{array}{c}0,114 \\
(0,149)\end{array}$ & $\begin{array}{c}0,060 \\
(0,141)\end{array}$ & $\begin{array}{l}8,511^{*} \\
(2,569)\end{array}$ & $\begin{array}{c}10,106^{*} \\
(2,958)\end{array}$ \\
\hline log_pop & $\begin{array}{l}-0,124 * \\
(0,026)\end{array}$ & $\begin{array}{l}-0,210^{*} \\
(0,026)\end{array}$ & $\begin{array}{l}4,660^{*} \\
(0,440)\end{array}$ & $\begin{array}{c}1,222 * * \\
(0,490)\end{array}$ \\
\hline \multicolumn{5}{|l|}{ idh } \\
\hline no & $\begin{array}{l}2,690^{*} \\
(0,193)\end{array}$ & $\begin{array}{l}2,360^{*} \\
(0,171)\end{array}$ & $\begin{array}{c}-19,652 * \\
(2,247)\end{array}$ & $\begin{array}{c}-11,921^{*} \\
(2,778)\end{array}$ \\
\hline ne & $\begin{array}{l}-0,334 * \\
(0,067)\end{array}$ & $\begin{array}{l}-0,241 * \\
(0,064)\end{array}$ & $\begin{array}{l}9,377^{*} \\
(1,294)\end{array}$ & $\begin{array}{c}11,897^{*} \\
(1,418)\end{array}$ \\
\hline $\mathrm{su}$ & $\begin{array}{l}-0,338^{*} \\
(0,066)\end{array}$ & $\begin{array}{l}-0,245^{*} \\
(0,064)\end{array}$ & $\begin{array}{r}20,270^{*} \\
(1,199)\end{array}$ & $\begin{array}{r}23,544^{*} \\
(1,288)\end{array}$ \\
\hline co & $\begin{array}{l}0,567 * \\
(0,092)\end{array}$ & $\begin{array}{l}0,472 * \\
(0,084)\end{array}$ & $\begin{array}{c}2,161 \\
(1,571)\end{array}$ & $\begin{array}{c}1,140 \\
(1,712)\end{array}$ \\
\hline privada_total & $\begin{array}{l}-0,777^{*} \\
(0,185)\end{array}$ & $\begin{array}{r}-0,352^{*} \\
(0,171)\end{array}$ & $\begin{array}{r}45,575^{*} \\
(2,699)\end{array}$ & $\begin{array}{c}40,369^{*} \\
(3,021)\end{array}$ \\
\hline \multicolumn{5}{|l|}{ local } \\
\hline local_publica & & $\begin{array}{l}1,279 * \\
(0,092)\end{array}$ & & $\begin{array}{r}21,449 * \\
(1,593)\end{array}$ \\
\hline \multicolumn{5}{|l|}{ local_privada } \\
\hline $\mathrm{c}$ & $\begin{array}{l}3,828^{*} \\
(0,228) \\
\end{array}$ & $\begin{array}{l}4,492 * \\
(0,227) \\
\end{array}$ & $\begin{array}{r}28,524^{*} \\
(3,691) \\
\end{array}$ & $\begin{array}{r}56,273^{*} \\
(4,093) \\
\end{array}$ \\
\hline$\overline{\mathrm{R}^{2}}$ & 0,9975 & 0,9978 & 0,9934 & 0,9918 \\
\hline $\mathrm{R}^{2}$ Ajustado & 0,9975 & 0,9978 & 0,9933 & 0,9917 \\
\hline Estatística F & 61677,69 & 54499,36 & 16939,01 & 11301,24 \\
\hline Probabilidade F & 0,0000 & 0,0000 & 0,0000 & 0,0000 \\
\hline Durbin-Watson & 1,9007 & 2,0308 & 1,9390 & 2,0249 \\
\hline Jarque-Bera & 1297,4650 & 896,1396 & 57,4746 & 26,5841 \\
\hline Probabilidade JB & 0,0000 & 0,0000 & 0,0000 & $2,00 \mathrm{E}-06$ \\
\hline
\end{tabular}


Em relação à variável empregados próprios por mil ligações de água e esgoto $\left(\mathbf{Y}_{10}\right)$, equação dezenove, indica que um município atendido por uma empresa privada apresenta uma queda de empregados próprios por mil ligações de água e esgoto num valor de 0,77 empregados por mil ligações de água e esgoto, uma vez que foi significativo a 1\% em relação ao município atendido por uma empresa regional, microrregional ou local (todas públicas). Contudo, a estimação vinte apresenta um coeficiente positivo e significativo a $1 \%$ para as locais públicas, num valor de 1,27 empregados por mil ligações de água e esgoto enquanto o coeficiente da empresa privada, também significativo a $1 \%$, apresentou sinal negativo representando queda de 0,35 empregados por mil ligações de água e esgoto. Entre elas, por meio de teste de hipóteses de igualdade entre seus coeficientes, a empresa privada apresenta menos empregados próprios por mil ligações de água e esgoto.

As próximas estimações, para a variável dependente referente ao índice de desempenho financeiro $\left(\mathbf{Y}_{\mathbf{1 1}}\right)$, receita operacional sobre despesas totais com os serviços, aponta o destaque das empresas privadas. Na equação vinte e um, o município ser atendido por uma empresa privada indica um aumento de 45,57 pontos percentuais nesse indicador. Esse resultado demonstra que esse tipo de empresa gera mais receita relativamente às despesas totais que efetua. As locais públicas também obtiveram um aumento no mesmo relativamente às regionais e microrregionais públicas, num valor de 21,44 pontos percentuais, como mostra a equação vinte e dois; mas as privadas aumentam o mesmo índice num valor maior, $40,36 \%$ e é diferente estatisticamente que as locais públicas. Segue abaixo, na tabela 4.9.4, uma possível relação entre as empresas, por meio da análise de desempenho, das estimações:

Tabela 4.9.4 - Relações entre os tipos de prestadores de serviços de saneamento

\begin{tabular}{lcc}
\hline Indicadores & Público x Privado & Regional $\mathbf{x}$ Local \\
\hline $\mathbf{Y}_{\mathbf{8}}=$ Tarifa & Priv_T $>$ Não_Loc_Pub $>$ Loc_Pub & Não_Loc_T $>$ Loc_Priv $>$ Loc_Pub \\
\hline $\mathbf{Y}_{\mathbf{9}}=$ Despesa Total & Priv_T $<$ Pub & - \\
\hline $\mathbf{Y}_{\mathbf{1 0}}=$ Empregados Próprios & Priv_T $<$ Loc_Pub $<$ Não_Loc_Pub & - \\
\hline $\mathbf{Y}_{\mathbf{1 1}}=$ Desempenho Financeiro & Priv_T $>$ Loc_Pub $>$ Não_Loc_Pub & - \\
\hline Fonte: Elaboração própria da autora. &
\end{tabular}

A tabela 4.9.3 a seguir mostra o grupo dos indicadores de investimentos. As variáveis dependentes utilizadas são: investimento total por ligação de água e esgoto, investimento total por habitante, investimentos realizados com recursos onerosos, investimentos realizados com 
recursos não onerosos e investimentos realizados com recursos próprios. Seguem os gráficos 4.4 e 4.5 que apresentam a média de cada variável para cada tipo de prestador:

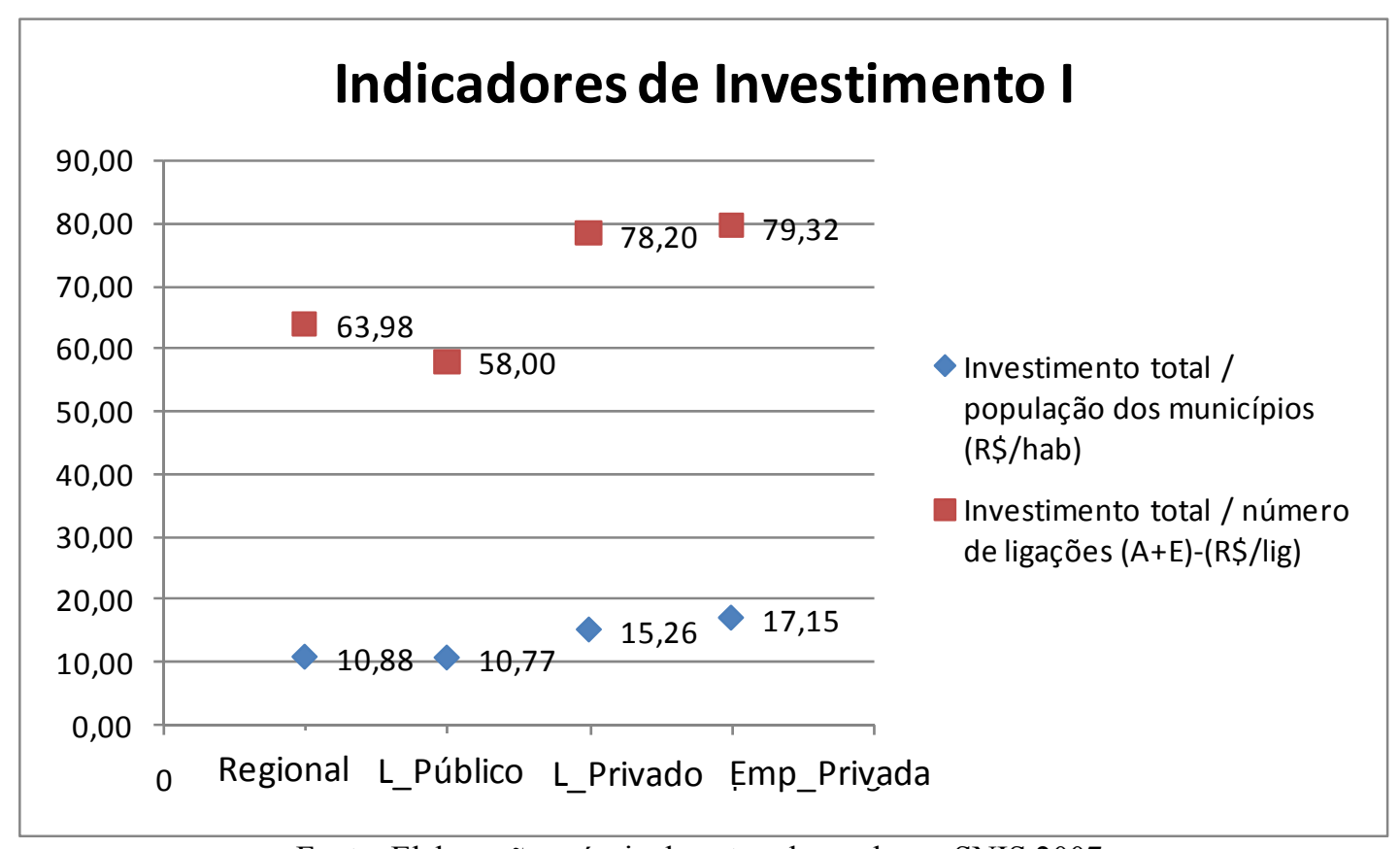

Fonte: Elaboração própria da autora baseada em SNIS 2007.

Gráfico 4.4 - Média por tipo de prestador dos indicadores de investimento I

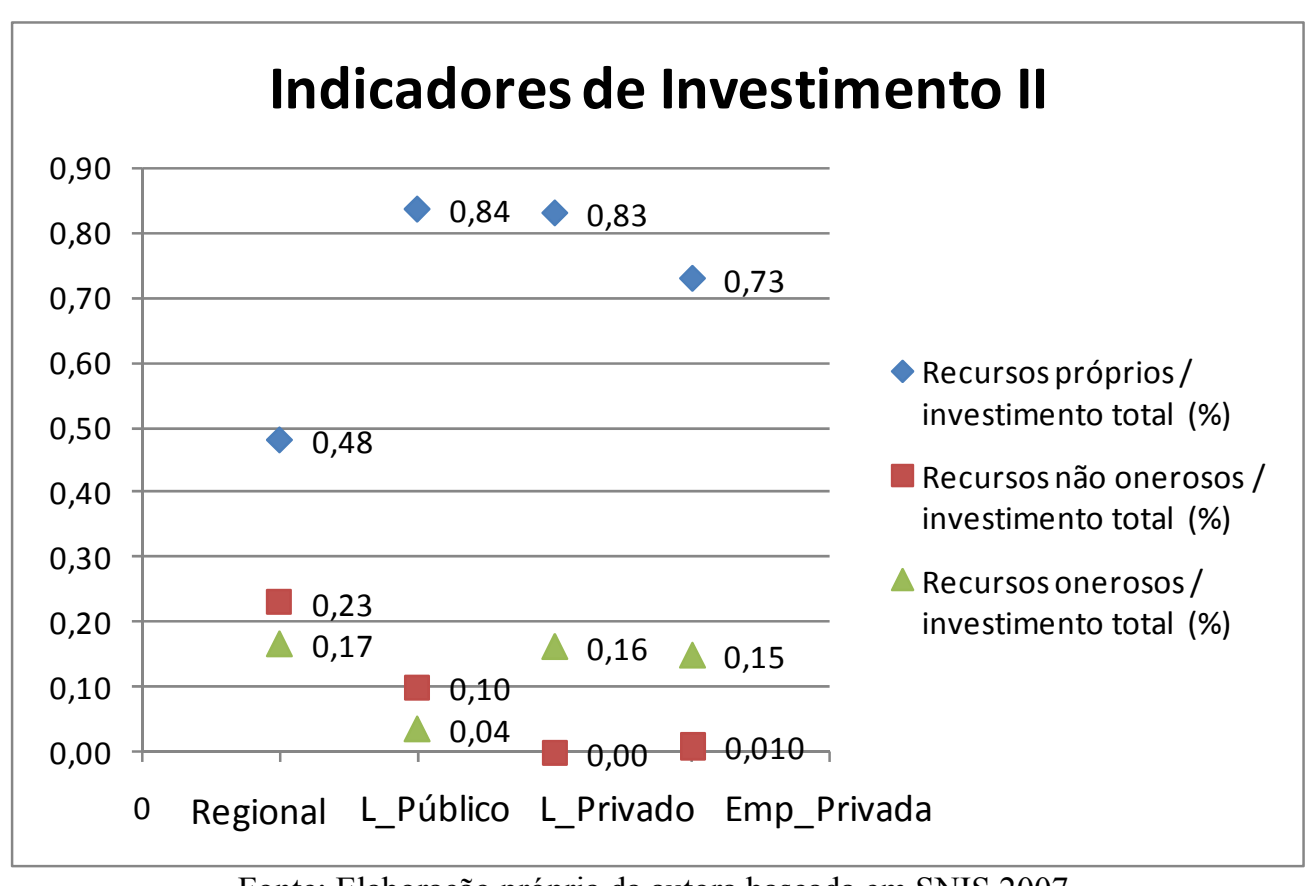

Fonte: Elaboração própria da autora baseada em SNIS 2007.

Gráfico 4.5 - Média por tipo de prestador dos indicadores de investimento II 
Como nos outros grupos, apresentam-se testes de média, na tabela 4.9.5, para cada variável a fim de verificar se a média é estatisticamente diferente entre os grupos, sem considerar as variáveis explicativas:

Tabela 4.9.5 - Teste de média indicadores investimento

\begin{tabular}{ccc}
\hline INDICADORES & priv total & local \\
\hline \multirow{2}{*}{ INVESTIMENTO POR HAB } & 3,889 & $4,543^{*}$ \\
& $(2,649)$ & $(1,953)$ \\
INVESTIMENTO POR LIG & $16,603^{* *}$ & 15,604 \\
& $(8,454)$ & $(11,428)$ \\
INVEST. REC PROPRIOS & $0,163^{*}$ & $0,538^{*}$ \\
& $(0,028)$ & $(0,021)$ \\
INVEST. REC. NÃO ONEROSOS & $-0,092^{*}$ & $-0,005$ \\
& $(0,007)$ & $(0,013)$ \\
INVEST. REC. ONEROSOS & $-0,041$ & $-0,036$ \\
& $(0,037)$ & $(0,040)$ \\
\hline
\end{tabular}

Fonte: Elaboração própria da autora baseada em SNIS 2007.

Verifica-se que somente para a variável, investimento por habitante, o grupo das empresas privadas não apresenta média maior em relação ao grupo das públicas. As locais, em média, investem mais, por habitante, do que as regionais. Abaixo segue a tabela 4.9.6 com as estimações: 
Tabela 4.9.6 - Estimação indicadores investimentos

\begin{tabular}{|c|c|c|c|c|c|}
\hline $\begin{array}{c}\mathbf{X}_{\mathbf{i}}=\text { Variáveis } \\
\text { Explicativas }\end{array}$ & $\begin{array}{c}Y_{12}= \\
\text { Investime } \\
\text { nto total } \\
\text { por } \\
\text { ligação de } \\
\text { água e } \\
\text { esgoto } \\
\text { (R\$/lig) }\end{array}$ & $\begin{array}{c}Y_{13}= \\
\text { Inves time } \\
\text { nto total } \\
\text { por } \\
\text { habitante } \\
\text { (R\$/hab) }\end{array}$ & $\begin{array}{c}\text { Y14 }=\text { Invest. } \\
\text { realizados } \\
\text { com } \\
\text { recurs os } \\
\text { oneros os } \\
(\%)\end{array}$ & $\begin{array}{c}\mathbf{Y}_{15}= \\
\text { Invest. } \\
\text { realizados } \\
\text { com } \\
\text { recursos } \\
\text { próprios } \\
(\%)\end{array}$ & $\begin{array}{c}\text { Y16 }=\text { Invest. } \\
\text { realizados } \\
\text { com } \\
\text { recursos } \\
\text { não } \\
\text { onerosos } \\
(\%)\end{array}$ \\
\hline & \multicolumn{5}{|c|}{ Coeficientes } \\
\hline & 23 & 24 & 25 & 26 & 27 \\
\hline renda & $\begin{array}{c}0,048 * * * \\
(0,027)\end{array}$ & & $\begin{array}{c}-2,50 \mathrm{E}-04 * * * \\
(1,40 \mathrm{E}-04)\end{array}$ & $\begin{array}{c}0,001 * * \\
(0,001)\end{array}$ & $\begin{array}{r}-6,11 \mathrm{E}-05^{*} \\
(4,69 \mathrm{E}-04)\end{array}$ \\
\hline urb & $\begin{array}{r}10,078^{*} \\
(0,883)\end{array}$ & $\begin{array}{l}3,691 * \\
(0,481)\end{array}$ & & $\begin{array}{l}0,175^{*} \\
(0,041)\end{array}$ & $\begin{array}{l}-0,019 \\
(0,024)\end{array}$ \\
\hline log_pop & $\begin{array}{l}1,852 * \\
(0,193)\end{array}$ & $\begin{array}{l}1,141 * \\
(0,099)\end{array}$ & $\begin{array}{l}0,018^{*} \\
(0,003)\end{array}$ & $\begin{array}{l}0,077^{*} \\
(0,007)\end{array}$ & $\begin{array}{l}0,018^{*} \\
(0,004)\end{array}$ \\
\hline idh & & $\begin{array}{c}14,055^{*} \\
(1,986)\end{array}$ & $\begin{array}{c}0,069 \\
(0,052)\end{array}$ & $\begin{array}{l}0,442^{*} \\
(0,164)\end{array}$ & \\
\hline no & $\begin{array}{r}-5,862 * \\
(0,822)\end{array}$ & $\begin{array}{l}-3,964^{*} \\
(0,423)\end{array}$ & $\begin{array}{c}-0,102 * \\
(0,010)\end{array}$ & $\begin{array}{l}0,101 * \\
(0,034)\end{array}$ & $\begin{array}{l}0,114^{*} \\
(0,020)\end{array}$ \\
\hline ne & $\begin{array}{l}-5,182 * \\
(0,445)\end{array}$ & $\begin{array}{l}-2,413 * \\
(0,294)\end{array}$ & $\begin{array}{c}-0,077 * \\
(0,009)\end{array}$ & $\begin{array}{c}0,001 \\
(0,022)\end{array}$ & $\begin{array}{l}0,182 * \\
(0,011)\end{array}$ \\
\hline $\mathrm{su}$ & $\begin{array}{l}-2,975^{*} \\
(0,545)\end{array}$ & $\begin{array}{r}-1,835^{*} \\
(0,296)\end{array}$ & $\begin{array}{r}-0,087 * \\
(0,008)\end{array}$ & $\begin{array}{l}0,261 * \\
(0,024)\end{array}$ & $\begin{array}{l}0,002 * \\
(0,013)\end{array}$ \\
\hline co & $\begin{array}{c}0,177 \\
(0,701)\end{array}$ & $\begin{array}{r}-1,734^{*} \\
(0,394)\end{array}$ & $\begin{array}{r}-0,076^{*} \\
(0,008)\end{array}$ & $\begin{array}{l}0,389^{*} \\
(0,024)\end{array}$ & $\begin{array}{c}0,026 * * * \\
(0,014)\end{array}$ \\
\hline privada_total & $\begin{array}{c}24,800 * \\
(1,297)\end{array}$ & $\begin{array}{l}7,897^{*} \\
(0,642)\end{array}$ & $\begin{array}{l}0,039^{*} \\
(0,013)\end{array}$ & $\begin{array}{l}0,160^{*} \\
(0,034)\end{array}$ & $\begin{array}{l}-0,074^{*} \\
(0,022)\end{array}$ \\
\hline $\begin{array}{l}\text { local_publica } \\
\text { local_privada }\end{array}$ & $\begin{array}{c}1,029 * * * \\
(0,567)\end{array}$ & $\begin{array}{c}0,581 * * * \\
(0,313)\end{array}$ & & & \\
\hline $\mathrm{c}$ & $\begin{array}{c}-14,796^{*} \\
(1,685)\end{array}$ & $\begin{array}{c}-17,847^{*} \\
(1,459)\end{array}$ & $\begin{array}{l}-0,125^{*} \\
(0,039)\end{array}$ & $\begin{array}{l}-0,890^{*} \\
(0,109)\end{array}$ & $\begin{array}{l}-0,165^{*} \\
(0,034)\end{array}$ \\
\hline $\mathrm{R}^{2}$ & 0,9966 & 0,9767 & 0,9963 & 0,8002 & 0,4448 \\
\hline $\mathrm{R}^{2}$ Ajustado & 0,9965 & 0,9766 & 0,9963 & 0,7989 & 0,4393 \\
\hline Estatística F & 30350,25 & 5032,88 & 58440,92 & 621,56 & 82,07 \\
\hline Probabilidade F & 0,0000 & 0,0000 & 0,0000 & 0,0000 & 0,0000 \\
\hline Durbin-Watson & 2,0591 & 2,0173 & 2,1574 & 1,7977 & 1,8679 \\
\hline Jarque-Bera & 350,9902 & 1074,7210 & 38211,6900 & 235,1535 & 5382,2850 \\
\hline Probabilidade JB & 0,0000 & 0,0000 & 0,0000 & 0,0000 & 0,0000 \\
\hline
\end{tabular}

Fonte: Elaboração própria da autora baseada em SNIS 2007. 
Quanto ao investimento total por ligação de água e esgoto $\left(\mathbf{Y}_{12}\right)$ - equação estimada número vinte e três - o município ter seus serviços de saneamento básico fornecidos por uma empresa privada aumenta em $\mathrm{R} \$ 24,80$ o investimento total por ligação de água e esgoto em relação às empresas não locais públicas. Da mesma forma, ocorre aumento nesse nível de investimento, ao considerar a variável local pública. Contudo, esse resultado deve ser visto com cautela, já que se refere a um pequeno aumento, $\mathrm{R} \$ 1,02$ por ligação, e o coeficiente é significativo a $10 \%$ para esse tipo de empresa. Ou seja, as locais públicas apresentam maior capacidade de investimento comparativamente às regionais e microrregionais, ambas públicas, porém não é uma diferença acentuada. Entre locais públicas e empresas privadas, essas últimas impactam mais esse índice do que as primeiras, conclusão obtida por meio de teste de hipóteses.

A mesma situação ocorre com a variável investimento total por habitante $\left(\mathbf{Y}_{13}\right)$, na equação vinte e quatro, o investimento total por habitante para as empresas privadas é significativo a $1 \%$ e representa um aumento de $\mathrm{R} \$ 7,89$ em relação às não locais públicas enquanto as locais públicas respondem por um aumento de apenas $\mathrm{R} \$ 0,58$ por habitante em relação ao mesmo grupo. Da mesma forma que ocorreu com a variável anterior, entre as locais públicas e empresas privadas, essas últimas impactam mais esse índice do que as primeiras.

Quanto à origem dos investimentos, a variável investimentos realizados com recursos onerosos $\left(\mathbf{Y}_{14}\right)$ mostra, na estimação vinte e cinco, que o município ser atendido por uma empresa de saneamento privada aumenta a parcela dos investimentos totais realizados com recursos onerosos (financiamentos), em 3,9\%. Contudo, esse valor é pequeno comparado ao obtido na equação vinte e seis que indica que o município ser atendido por uma empresa privada de saneamento provoca um aumento da parcela dos investimentos totais realizados com recursos próprios $\left(\mathbf{Y}_{15}\right)$, em 16,0\%. Por fim, a equação vinte e sete relativa à variável investimentos realizados com recursos não onerosos $\left(\mathbf{Y}_{16}\right)$ apresenta queda em relação às empresas públicas, uma vez que as privadas não se utilizam de recursos não onerosos (como por exemplo, recursos a fundo perdido) para realizar seus investimentos. A tabela 4.9.7, que resume as principais conclusões em relação aos indicadores de investimentos, é apresentada a seguir: 
Tabela 4.9.7 - Relações entre os tipos de prestadores de serviços de saneamento

\begin{tabular}{|c|c|c|}
\hline Indicadores & Público x Privado & Regional $x$ Local \\
\hline $\mathbf{Y}_{9}=$ Investimento/habitante & Priv_T > Loc_Pub> Não_Loc_Pub & - \\
\hline$Y_{10}=$ Investimento/ligação & Priv_T > Loc_Pub> Não_Loc_Pub & - \\
\hline$Y_{11}=$ Inv. Rec. Onerosos & Priv $>$ Pub & - \\
\hline$Y_{12}=$ Inv. Rec. Proprios & Priv $>$ Pub & - \\
\hline$Y_{13}=$ Inv. Rec. Não Onerosos & Priv $<$ Pub & - \\
\hline
\end{tabular}

Fonte: Elaboração própria da autora.

O último grupo analisado refere-se ao índice de qualidade expresso pela fórmula apresentada em apêndice, que varia entre zero e um: quanto mais próximo de um melhor a qualidade dos serviços prestados por cada tipo de empresa. Apresenta-se, primeiramente, o gráfico 4.6 para essa variável que indica a média para cada diferente tipo de prestador:

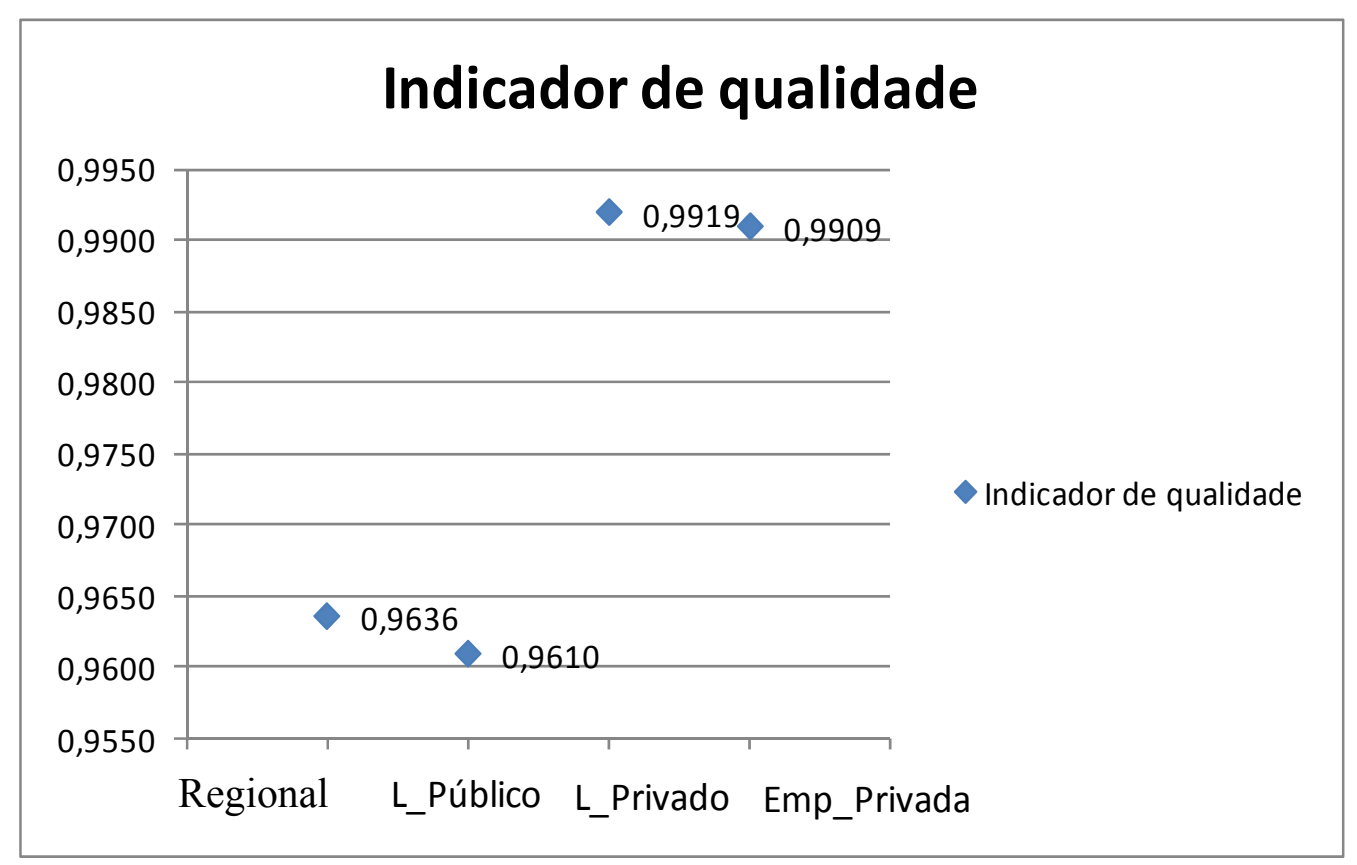

Fonte: Elaboração própria da autora baseada em SNIS 2007.

Gráfico 4.6 - Média por tipo de prestador dos indicadores de qualidade

O teste de média, da tabela 4.9.8 abaixo, evidencia que o grupo das empresas privadas exibe maior índice de qualidade em relação ao grupo das empresas públicas. Contudo, não se pode dizer o mesmo para o grupo das locais. 
Tabela 4.9.8 - Teste de média indicador qualidade

\begin{tabular}{ccc}
\hline INDICADOR & priv_total & local \\
\hline \multirow{2}{*}{ QUALIDADE } & $0,028^{*}$ & $-0,0004$ \\
& $(0,001)$ & $(0,003)$ \\
\hline Fonte: Elaboração própria da autora baseada em SNIS 2007.
\end{tabular}

A última tabela de estimações, 4.9.9, apresenta os resultados para essa variável (indicador de qualidade) considerando agora os controles no modelo:

Tabela 4.9.9 - Estimação indicador de qualidade

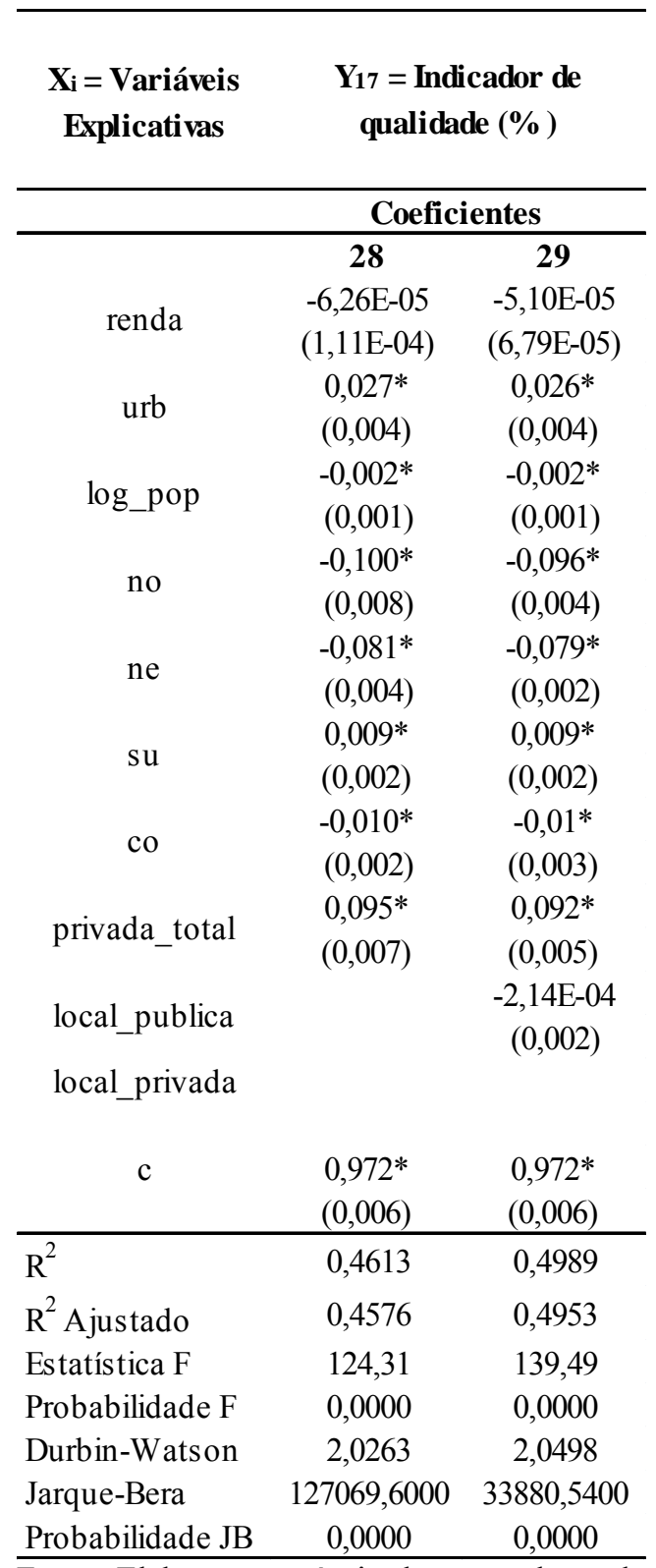

Fonte: Elaboração própria da autora baseada em SNIS 2007. 
Em relação à estimação número vinte e oito verifica-se que a empresa privada apresenta aumento no indicador de qualidade de 0,095, significativo a 1\%. Por exemplo, se um município que tem um indicador de qualidade de 0,90 for atendido por uma empresa privada, esse indicador sobe para 0,995 comparativamente a todas as públicas. Ou seja, o índice de qualidade aumenta substancialmente. Por fim, na equação vinte e nove, ao introduzir a variável local pública, esse tipo de empresa não apresenta um coeficiente significativo para essa variável, mas a empresa privada apresentou, aproximadamente o mesmo valor que anteriormente, 0,092, também a 1\% de significância. Segue tabela 4.9.9.1 para esse último indicador, como foi apresentada para os outros grupos:

Tabela 4.9.9.1 - Relações entre os tipos de prestadores de serviços de saneamento

\begin{tabular}{lcc}
\hline Indicador & Público x Privado & Regional x Local \\
\hline $\mathbf{Y}_{7}=$ Qualidade & Priv_T $>$ Pub & - \\
\hline Fonte: Elaboração própria da autora baseada em SNIS 2007. &
\end{tabular}




\section{CONSIDERAÇÕES FINAIS}

A estrutura de oferta do setor de saneamento básico brasileiro, traçada a partir dos dados do SNIS, mostrou sua heterogênea forma de provisão. Decorrente das influências do Planasa, que criou as Companhias Estaduais de Saneamento Básico (CESBs), existem hoje 26 prestadores regionais responsáveis por grande parte da cobertura dos serviços: cada um deles atende a uma quantidade considerável de municípios, ou seja, a provisão é essencialmente pública e centralizada.

Contudo, nem todos os municípios delegaram às antigas CESBs a concessão dos serviços, muitos optaram por prestá-los localmente. Dessa forma, foram denominados pelo SNIS, como prestadores locais, por atenderem a um único município. Por fim, os prestadores microrregionais surgiram pela associação de alguns poucos municípios via consórcio intermunicipal.

A despeito desses três grupos de prestadores, existem seis possibilidades de natureza jurídica que foram resumidas em apenas duas, para simplificar a análise econométrica: empresas públicas (administração pública direta, autarquia, sociedade de economia mista com administração pública e sociedade de economia mista com administração privada) e empresas privadas.

A primeira etapa para responder a questão desse estudo foi o cálculo de estatísticas descritivas para cada grupo de prestador em relação aos indicadores selecionados do SNIS: calculou-se a média por tipo de prestador em relação aos indicadores operacionais (de água e esgoto), econômicos, financeiros, administrativos, de investimento e de qualidade. Foi possível concluir que os indicadores foram inconclusivos quanto à predominância de algum tipo de prestador específico, que apresentasse o melhor desempenho médio, na provisão dos serviços.

Posteriormente, foi realizado um teste de média com o objetivo de verificar se existe diferença, estatisticamente significante, entre as médias dos dois grupos estabelecidos: empresas públicas e empresas privadas (independente da abrangência geográfica de cada uma delas) e empresas locais e não locais (sem considerar o tipo de natureza jurídica que exibem), sem utilizar nenhuma variável explicativa como controle.

A terceira e última etapa consistiu em estimação de variáveis de desempenho, obtidas dos indicadores selecionados do SNIS, devidamente controladas pelas variáveis explicativas: 
renda per capita municipal, localização geográfica, taxa de urbanização, porte do município e a variável de interesse, tipo de estrutura de governança do prestador atuante no município.

Ao analisar os resultados do grupo dos indicadores operacionais de água, na média, verifica-se que o índice de atendimento de água tende a ser maior nos municípios que são atendidos por empresas locais públicas. Os indicadores de produtividade indicam que as locais privadas perdem menos na distribuição de água e no faturamento. Porém no índice de densidade de economias de água por ligação, as regionais apresentam maior valor. Dessa forma, cada grupo apresentou melhor desempenho em um tipo de indicador.

Ao estimar as equações, via método econométrico, verifica-se menor grau de inconclusão: sem considerar o indicador de atendimento total de água, todos os outros indicadores indicam que a empresa privada exibiu melhor desempenho, pois apresentou menores perdas na distribuição, no faturamento e maior densidade de economias de água por ligação.

Em relação aos valores médios dos índices operacionais de esgoto, para 2007, os prestadores locais públicos também apresentam maior índice de atendimento total de esgoto. Contudo, a diferença em relação ao prestador local privado é pequena. Mantendo a mesma tendência observada no ano de 2002, as locais públicas continuam coletando mais e tratando menos em comparação com as regionais que tratam mais e coletam menos.

O baixo grau de tratamento nas públicas locais reflete um ponto interessante relacionado às externalidades ambientais e à necessidade de coordenação regional dessas políticas. A preocupação das empresas locais pode ser a coleta e afastamento do esgoto que beneficia diretamente seus habitantes enquanto a ausência de tratamento distribui o ônus com os municípios vizinhos (TONETO; SAIANI, p. 586, 2006).

Esse resultado obtido nas estatísticas descritivas foi confirmado nas estimações econométricas: o coeficiente da variável "local" foi estatisticamente significante a $1 \%$ para as variáveis índice de coleta e tratamento de esgoto. Além disso, as regressões também mostram que, para os indicadores operacionais de esgoto, a natureza jurídica da gestão da empresa é apenas marginalmente relevante para explicar os resultados dos indicadores.

É importante ressaltar que, tanto para água quanto para esgoto, mesmo com o destaque das locais públicas nos indicadores de acesso, os coeficientes das empresas privadas foram significativos quando comparados com as empresas regionais e microrregionais públicas, isso pode indicar uma tendência das empresas privadas atuarem em municípios nos quais o índice de atendimento seja alto: talvez os contratos com as empresas privadas não sejam 
estabelecidos em caráter emergencial, para sanar problemas que o operador público não consegue solucionar, mas sim porque oferecem maior atratividade financeira, em termos de rentabilidade. Dessa forma, pode-se sugerir que esteja ocorrendo o início do processo de amadurecimento de tais empresas no setor, pois não atuam somente em municípios nos quais o atendimento é baixo. Além disso, pode-se pensar que a parceria seja feita a fim de oferecer serviços de melhor qualidade à população.

No grupo de indicadores operacionais, os sinais esperados das funções objetivo foram todos atendidos: a função social dos operadores locais públicos se verifica, pois fornece serviços em regiões não atrativas para o investimento privado, e como era esperado também, as empresas públicas apresentam índices maiores de perdas de faturamento e distribuição.

Quanto aos indicadores econômicos, financeiros e administrativos, as empresas privadas apresentaram maiores níveis de tarifa média praticada em relação às regionais, microrregionais e locais públicas: possivelmente tanto pelo fato de atuarem em regiões mais prósperas quanto por necessitarem cobrir seus custos e/ou obter retorno de seus investimentos por meio das mesmas. Torna-se necessário, portanto, estabelecer devidamente, em contrato, adequadas normas tarifárias a fim de que essas não se tornem abusivas.

Em nível de abrangência geográfica, as empresas regionais e microrregionais também apresentam maiores tarifas. De fato, essas empresas apresentam histórico de cobrar tarifas mais elevadas pelo fato de operar em maior escala e em diversos municípios que apresentam diferentes custos de provisão dos serviços.

Com relação às tarifas médias praticadas, as públicas locais cobram as menores tarifas, o que decorre, segundo Toneto e Saiani (2006), tanto de facilidades tributárias dessas empresas como pode refletir a maior dificuldade política de se cobrar dos consumidores pela proximidade entre eleitor e gestor do serviço.

No que diz respeito aos indicadores restantes desse grupo (de produtividade e desempenho financeiro), as empresas privadas apresentaram melhor desempenho: menor despesa total por $\mathrm{m}^{3}$ faturado, menor número de empregados próprios por mil ligações de água e esgoto e maior índice de desempenho financeiro.

Cabe uma observação quanto a esse último indicador: pelo fato de indicar que as empresas privadas geram mais receita relativamente às despesas totais que efetua talvez essa ocorrência possa ser atribuída às maiores tarifas e ao menor nível de despesa efetuado, uma vez que tais empresas conseguem ser mais produtivas. 
O relativo caso de sucesso da atuação do setor privado na esfera do saneamento ocorreu na cidade de Limeira (SP), que teve concessão plena para operação dos serviços. A empresa conseguiu reduzir custos com a queda do índice de perdas e das despesas de exploração. Contudo, uma dificuldade encontrada pela mesma esteve no pagamento de dividendos aos acionistas, uma vez que as remessas de lucros se constituíram num problema de financiamento. Para manter os investimentos necessários a sua operação e conseguir enviar tais remessas, o nível real de tarifas deveria ser maior do que aquele estabelecido pela PML (Prefeitura Municipal de Limeira) anteriormente.

De fato, a população sofreu com o aumento de tarifa (com exceção de cinco mil famílias carentes que tinham acesso a uma "tarifa social", que representava o pagamento de apenas metade do serviço), mas houve o oferecimento de um serviço de qualidade, alavancagem de investimentos ( $\mathrm{R} \$ 30$ milhões só em estações de tratamento de esgoto) e maiores possibilidades de retorno no longo prazo para a empresa.

O novo marco regulatório do setor de saneamento básico, lei 11.445/2007, trouxe perspectivas de resolução de alguns problemas tarifários que prejudicam não só a população de baixa renda, mas todos os consumidores de forma geral. De acordo com a nova lei, o contrato de concessão firmado entre o titular e o prestador de serviços de saneamento, deve deixar indicado, de forma transparente, qual será a definição de taxas e tarifas, as regras de reajustes e revisões, as formas de cobrança e os programas de tarifa social. O titular do serviço deve definir o órgão ou agência responsável pela regulação de forma a controlar, entre outras funções, o cumprimento de execução de tarifas justas pelos concessionários.

É possível destacar uma possível tendência de que a ineficiência dos operadores públicos nos índices de produtividade e de maiores perdas de faturamento e distribuição pode estar relacionada à execução da função social dos mesmos. Segundo Borger e Parente (2008), no estudo de caso sobre o processo de revitalização da maior empresa de saneamento do Brasil, a Sabesp, muitos funcionários consideravam que "saneamento é saúde" e, portanto, os investimentos seriam justificados por suas expressivas externalidades sociais, enquanto os resultados financeiros ficariam em segundo plano, ou seja, a geração de caixa para fazer frente às despesas não era considerado uma prioridade (BORGER; PARENTE, p. 171, 2008).

Em relação às funções-objetivo do grupo dos indicadores econômicos, financeiros e administrativos todos os sinais esperados para os dois grupos de empresas foram confirmados pelos resultados obtidos da análise empírica. 
Os indicadores de investimento mostram uma prevalência das empresas privadas no aumento de tais índices, tanto para investimento total por ligação e quanto para investimento total por habitante. Esse resultado mostra a maior capacidade que as empresas privadas possuem de alavancar investimentos e também pode indicar que o advento do novo marco regulatório gerou uma retomada dos mesmos.

Considerando a origem de tais investimentos, é possível constatar que as empresas privadas aumentam a parcela dos investimentos realizados com recursos onerosos e com recursos próprios, sendo que esses últimos são maiores que os primeiros. Esse fato comprova a suposição anterior de que é possível que os investimentos realizados por tais empresas provenham em parte de seu desempenho financeiro, via geração de receita por meio de imposição de tarifas mais elevadas. Contudo, a capacidade de endividamento ainda é importante, ainda mais num cenário em que a maioria das empresas estaduais não consegue tomar empréstimos pelo fato de encontrarem-se endividadas e sujeitas a restrições fiscais, o que provoca estagnação do montante de investimentos necessário para o desenvolvimento do setor.

As estatísticas descritivas, na tabela 3.8, chamam atenção para o fato de que, em 2007, o maior grau de endividamento foi das privadas: relativamente ao ano de 2002 , houve um aumento de $151 \%$ nesse índice, que pode refletir a característica dessas entidades poderem tomar mais empréstimos. Contudo, verifica-se com os dados de investimento, que a maior parte deles vem sendo realizada via recursos próprios: decorrência de maiores ganhos financeiros, estimulados pela aplicação de tarifas mais elevadas. Os dados da mesma tabela podem confirmar esse fato uma vez que as empresas privadas apresentaram elevada margem líquida, que pode ser definida, de maneira intuitiva, como o lucro líquido por unidade vendida.

A análise dos dados de balanço também demonstra que essa margem líquida, para as empresas regionais, se apresentou negativa, apesar de ter ocorrido uma significativa melhora para 2007. Isso demonstra as dificuldades financeiras encontradas por tais empresas, uma vez que a margem operacional (lucro operacional por unidade de serviço vendida) foi positiva, apesar de decrescente. De forma geral, novamente, os sinais esperados das funções objetivo para cada grupo de empresa foram observados.

A empresa privada também se destaca no indicador referente à qualidade dos serviços. Da mesma forma, estudo da Fundação Getúlio Vargas, encomendado pelo Ministério das Cidades, sobre a Participação do Setor Privado (PSP) na qualidade de 
abastecimento de água e esgotamento sanitário no Brasil, concluiu que, em nível nacional, houve melhora no desempenho desses serviços.

A pesquisa foi feita com 50 empresas privadas com pelo menos três anos de atuação, envolvendo uma população total de 11 milhões de habitantes - o que significa 7\% do total do país. Um dos pontos que contribuíram para o resultado foi à continuidade política, ou seja, a participação de prefeituras ou governos estaduais no início da gestão da PSP - entre o período de licitação e operação efetiva da iniciativa privada. Além desse fator, as empresas que estavam localizadas em regiões de maior nível de renda per capita apresentaram melhor desempenho.

Galiani, Gertler e Schargrodsky (2003) encontraram baixos (e significativos) níveis de mortalidade infantil na Argentina, causados por doenças transmissíveis pela água, em localidades que privatizaram seus serviços em relação às cidades que mantiveram a provisão estatal dos mesmos. Entre outros fatores, esse resultado, segundo os autores, pode estar relacionado a um maior nível de qualidade na água distribuída.

Portanto, garantir um nível adequado de qualidade da água, não provoca somente benefícios ao meio ambiente, mas principalmente evita a proliferação de vetores que causam doenças infecto-contagiosas, principal causa da mortalidade infantil tanto no Brasil como em inúmeros países da América Latina.

De forma geral, estudos do Instituto Mundial para a Investigação em Economia do Desenvolvimento (World Institute of Development Economics Research - WIDER) da Universidade das Nações Unidas (UNU) concluíram que a privatização da infra-estrutura na América Latina melhorou o desempenho financeiro e operacional de muitas firmas, relaxou as restrições de investimento, aumentou a cobertura de rede, o acesso à mesma pela população $\mathrm{e}$ gerou ganhos de qualidade dos serviços.

De fato, grande parte dessas conclusões foi confirmada com os resultados apresentados nesse estudo. Contudo, isso não implica que a alternativa de privatização seja a mais adequada para o setor: as características peculiares do mesmo trazem preocupações com a questão do acesso a um direto elementar do ser humano que é água segura.

As empresas privadas apresentam uma tendência a operarem em regiões mais prósperas que ofereçam maior rentabilidade para seus investimentos, o que pode excluir as populações com menor poder aquisitivo do acesso. De fato, nos indicadores de atendimento de água/esgoto são as locais públicas que apresentam melhor desempenho. 
Cabral, Lazzarini e Azevedo (2007), também colocam outra preocupação da atuação do agente privado no oferecimento de serviços públicos: muitas vezes optam por sacrificar a qualidade dos mesmos para reduzir custos e obter maiores lucros, ou seja, enfrenta um tradeoff entre custo e qualidade. Os resultados obtidos na presente dissertação mostram que esse dilema, por ora, pode não ser enfrentado pelos operadores privados no setor de saneamento, pois apresentaram menores índices de despesa total por $\mathrm{m}^{3}$ de água faturado e maiores índices de qualidade.

Assim, para solucionar ambas as preocupações acerca da participação da iniciativa privada no setor, é necessário que exista a presença do marco regulatório: sem a garantia do poder público de oferecer regulação e planejamento as vantagens da associação entre eles podem se tornar perversas.

Segundo Motta (2006), uma regulação que vise ao bem-estar da sociedade não deve distinguir prestação direta ou indireta, pública ou privada. Deve sim, garantir o respeito aos contratos e o uso adequado dos incentivos à eficiência (inclusive os de escala ótima), à expansão dos serviços (inclusive as metas) e à modicidade tarifária (inclusive as formas de subsídios), seja qual for a forma de prestação dos serviços.

Atualmente, a nova lei trouxe perspectivas de que esses objetivos elencados por $\operatorname{Motta}(2006)$ ocorram e de que a participação da iniciativa privada no setor de saneamento básico brasileiro possa se dar de forma positiva a fim que de seu desempenho em termos de produtividade, qualidade e investimento proporcionem o aumento da eficiência e a melhor gestão dos recursos financeiros contribuindo para o desenvolvimento do setor.

Por outro lado, o estímulo das parcerias por si só, nesse momento que o saneamento vive, não solucionaria todas as suas dificuldades, uma vez que é predominante no país o sistema centralizado de empresas públicas estaduais, que se encontra em situação financeira precária. A maior parte de tais empresas não apresenta garantias para acessar os recursos do Fundo de Garantia do Tempo de Serviço (FGTS) e do Fundo de Amparo ao Trabalhador (FAT) e, assim, a realização dos investimentos necessários à universalização no setor fica estagnada.

A situação se torna mais preocupante ao se avaliar as estimativas realizadas pelo Ministério das Cidades (2000) para se atingir essa universalização: investindo cerca de aproximadamente R $\$ 10$ bilhões por ano, o Brasil, segundo uma perspectiva otimista, levaria 27 anos para eliminar o déficit no setor. Se for considerado o valor que tem sido investido 
anualmente, cerca de $\mathrm{R} \$ 4,5$ bilhões, seriam necessários por volta de 60 anos para universalizar o saneamento no Brasil.

Portanto, dada a importância da atuação do governo federal no setor, é necessário que se pense na recuperação de tais empresas via mecanismos de reestruturação econômica, de gestão e modernização. Porém, cabe observar que o avanço das parcerias, e a busca de novas fontes alternativas de recursos em substituição ao investimento público, devem ocorrer, no mínimo, paralelamente à execução dos planos de reestruturação dessas empresas, caso contrário, possivelmente a população estará fadada a viver sem serviços de saneamento num prazo possivelmente superior aos 60 anos estimados, pois além das externalidades sociais que a falta de tais serviços causam à população existe ainda o impacto em diversos setores produtivos do país, perpetuando, conseqüentemente, os "germens" do subdesenvolvimento econômico.

Dessa forma, a presente dissertação teve o objetivo de mostrar os impactos positivos que as parcerias público-privadas vêm trazendo para o setor. Essa evidência foi constatada pelo desempenho das empresas privadas que tiveram suas funções-objetivo, enunciadas pela literatura do setor, confirmadas na maior parte dos indicadores.

Logo, pretendeu-se exibir mais um argumento que demonstrasse como as parcerias entre setor privado e público, estimuladas e implantadas pelo novo ambiente institucional, que teve início com a aprovação da Lei das Parcerias Público-Privadas (2004), dos Consórcios Públicos (2005) e se consolidou com a Lei do Saneamento Básico (2007), podem contribuir para aumentar o volume de investimentos destinados ao setor e, quem sabe assim, ao se constituir em ação efetiva para acelerar a universalização dos serviços, consiga alterar a "sentença", delegada indiretamente à população excluída do acesso aos serviços de saneamento, de viver por mais 60 anos sem esses serviços fundamentais para a sobrevivência e dignidade humana. 


\section{BIBLIOGRAFIA}

ASCHAUER, D. A. Is public expenditure productive? Journal of Monetary Economics, Holland, v. 23, n. 23: p. 177-2000, 1989.

BARRETO, M. L.; STRINA A. et. al. Effect of city-wide sanitation programme on reduction in rate of childhood diarrhea in northeast in northeast Brazil: assment by two corhort studies. The Lancet. England, v. 370, n. 9599, p. 1622-1628, nov. 2007.

BIELSCHOWSKY (coord) et al. Investimento e reformas no Brasil: indústria e infraestrutura nos anos 1990. Brasília: Ipea/Cepal, 2002.

BORGER, F. G.; PARENTE, V. Empresa de Saneamento em São Paulo: Desafios de uma empresa estatal. In: ANUATTI NETO, F.; MELlO, M. F. (Orgs). Regulação da infraestrutura no Brasil: casos didáticos, São Paulo: Editora Singular, 2008.

BRASIL. Constituição (1988). Constituição da República Federativa do Brasil. Brasília, DF: Senado, 1988.

Ministério das Cidades, Consórcio Inecon e Fundação Getúlio Vargas. Exame da Participação do Setor Privado na Provisão dos Serviços de Abastecimento de Água e de Esgotamento Sanitário no Brasil, São Paulo, 2008. Disponível em: $<$ http://www.cidades.gov.br/secretarias-nacionais/saneamento-ambiental/biblioteca/exameda-participacao-do-setor-privado-na-provisao-dos-servicos-de-abastecimento-de-agua-e-deesgotamento-sanitario-no-brasil-estudo-psp>. Acesso em: 19 mar 2009.

Instrução Normativa no 949, de 25 de fevereiro de 1967. Dispõe sobre a organização da Administração Federal, estabelece diretrizes para a Reforma Administrativa e dá outras providências. Presidência da República Casa Civil. Disponível em: $<$ http://www.planalto.gov.br/ccivil/Decreto-Lei/Del0200.htm >. Acesso em: 09 ago. 2008.

Decreto-Lei no 200, de 25 de fevereiro de 1967. Dispõe sobre a organização da Administração Federal, estabelece diretrizes para a Reforma Administrativa e dá outras providências. Presidência da República Casa Civil. Disponível em: <http://www.planalto.gov.br/ccivil/Decreto-Lei/Del0200.htm >. Acesso em: 09 ago. 2008.

Decreto no 82.587, de 6 de novembro de 1978. Regulamenta a Lei ${ }^{\circ} 6.528$, de 11 de maio de 1978, que dispõe sobre as tarifas dos serviços públicos de saneamento e dá outras 
providências. Presidência da República subchefia para Assuntos Jurídicos. Disponível em: $<$ http://www.planalto.gov.br/ccivil_03/decreto/D82587.htm >. Acesso em: 09 ago. 2008.

BRASIL. Decreto no 8.036, de 11 de maio de 1990. Dispõe sobre o Fundo de Garantia do Tempo de Serviço, e dá outras providências. Presidência da República Casa Civil subchefia para Assuntos Jurídicos. Disponível em: $<$ http://www.planalto.gov.br/ccivil_03/LEIS/L8036consol.htm >. Acesso em: 09 ago. 2008.

Lei no 8.666, de 21 de junho de junho de 1993. Dispõe sobre licitações e contratos públicos. Presidência da República Casa Civil. Disponível em: $<$ http://www.planalto.gov.br/ccivil/Leis/L8666cons.htm >. Acesso em: 09 ago. 2008.

Lei no 8.987, de 13 de fevereiro de 1995. Dsipõe sobre o regime de concessão e permissão da prestação de serviços públicos previsto no art. 175 da Constituição Federal, e dá outras providências.. Presidência da República Casa Civil. Disponível em: $<$ http://www.planalto.gov.br/ccivil_03/LEIS/L8987cons.htm >. Acesso em 01 set. 2008.

Lei no 5.172, de 25 de outubro de 1996. Dispõe sobre o Sistema Tributário Nacional e

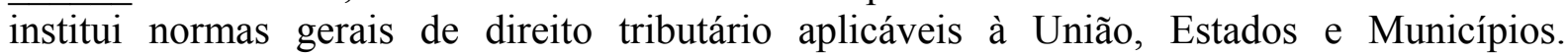
Presidência da República Casa Civil. Disponível em: $<$ http://www.planalto.gov.br/ccivil_03/LEIS/L5172.htm >. Acesso em: 09 ago. 2008.

Lei no 101, de 04 de maio de 2000. Dipõe sobre normas de finanças públicas voltadas para a responsabilidade na gestão fiscal e dá outras providências. Presidência da República Casa Civil. Disponível em: < http://www.planalto.gov.br/CCIVIL/Leis/LCP/Lcp101.htm>. Acesso em 11 set. 2008.

Lei no 11.079 , de 30 de dezembro de 2004. Dipõe sobre licitação e contratação de parceria público-privada no âmbito da administração pública. Presidência da República Casa Civil. Disponível em: <http://www.planalto.gov.br/ccivil_03/_ato20042006/2004/Lei/L11079.htm>. Acesso em 11 set. 2008.

Lei no 11.445 , de 05 de janeiro de 2007. Dispõe sobre diretrizes nacionais para o saneamento básico; altera as Leis no 6.766, de 19 de dezembro de 1979, 8.036, de 11 de maio de 1990, 8.666, de 21 de junho de 1993, 8.987, de 13 de fevereiro de 1995 e revoga a Lei no 6.528, de 11 de maio de 1978; e dá outras providências. Presidência da República Casa Civil. Disponível em: $\quad<$ http://www.planalto.gov.br/ccivil_03/_ato20072010/2007/lei/111445.htm >. Acesso em 11 set. 2008.

Ministério das Cidades, Programa de Modernização do Setor de Saneamento, Secretaria Nacional de Saneamento Ambiental, PNUD, "Dimensionamento da Necessidade de 
Investimentos para Universalização dos Serviços de Água e Esgotos no Brasil”, Brasília, 2003.

BRASIL. Ministério da Saúde, Fundação Nacional da Saúde, FUNASA, "Projeto Água da Chuva leva abastecimento a moradores do semi-árido. Disponível em: $<$ http://portal.saude.gov.br/portal/saude/visualizar_texto.cfm?idtxt=24624>. Acesso em 01 . dez. 2009.

Programa das Nações Unidas, "Objetivos de Desenvolvimento do Milênio". Disponível em: < http://www.pnud.org.br/odm/>. Acesso em 15 out. 2008.

Organização das Nações Unidas para a Educação, a Ciência e a Cultura, UNESCO no Brasil, Nova York, 2009. Disponível em: < http://webworld.unesco.org/water/ wwap/wwdr/wwdr3/index.shtml>. Acesso em 10. dez. 2009.

CABRAL, S.; LAZZARINI, S. G.; AZEVEDO, P. F. Private operation with public supervision: evidence of hybrid modes of governance in prisons. Social Science Research Network, set. 2007. Disponível em: <http://papers.ssrn.com/sol3/papers.cfm?abstract _id=1017801>. Acesso em: 13 fev. 2007.

CANNING, D. The Contribution of infrastructure to aggregate output. The World Bank Policy Research Working Paper, n. 2246, nov. 1999.

CASTRO, C. E. T. Avaliação da eficiência gerencial de empresas de água e esgotos brasileiras por meio da envoltória de dados (DEA). Dissertação (Mestrado), Departamento de Engenharia Industrial, Pontifícia Universidade Católica do Rio de Janeiro, Rio de Janeiro, 2003 .

DEMETRIADES, P.; MAMUNEAS, T. Intertemporal output and employment effects of public infrastructure capital: evidence from 12 OECD economies. Economic Journal, v. 110, p. $687-712,2000$.

FERNANDOIS, R. A. Fomento de la eficiência de las empresas estatales de água potable y saneamiento, Serie recursos naturales e infraestructura, n.141, março 2009, Santiago de Chile.

GALIANI, S. GERTLER, P. \& SCHARGRODSKY, E. Water for Life: the Impact of the Privatization of Water Services on Child Mortality. Journal of Political Economy, v. 113, n.1, 2005. 
GALVÃO, A. C. J; PAGANINI, W. S. da. Aspectos conceituais da regulação dos serviços de água e esgoto no Brasil. Artigo Técnico Eng. Sanit. Ambient., v.14, n.1, jan/mar 2009, p. 79-88.

GIAMBIAGI, F.; ALÉM A. C. Finanças Públicas: teoria e prática no Brasil. Rio de Janeiro: Elsevier, 2 ed, 2000.

GUJARATI, D. N. Econometria básica. Rio de Janeiro: Elsevier, 2006.

HIL, R. C.; GRIFFITHS, W. E.; JUDGE, G. G. Econometria. São Paulo: Saraiva, 2000.

HIRATUKA, C. et al. Importância socioeconômica da cadeia de serviços de saneamento básico no Brasil. In: GESNER, O.; SCAZUFCA, P. (Orgs). A economia do saneamento no Brasil, São Paulo: Editora Singular, 2009.

IBGE. Instituto Brasileiro de Geografia e Estatística. Censo Demográfico. Brasília, 1970, 1980, 1990, 2000. Disponível em: <http://www.ibge.gov.br/censo/>. Acesso em: 15 fev. 2007.

JOURALEV, A.; LEE, R.T. Private participation in the provision of water services: alternative means for private participation in the provision of water services, Serie Medio Ambiente y Desarrollo, n. 2, maio 2007.

MELLO, M. F. Privatização do setor de saneamento no Brasil: quatro experiências e muitas lições. Rio de Janeiro: PUC-RIO, p. 1-23, set. 2001. (Texto para Discussão, n. 447).

MELlO, M, F de. Concessão de saneamento ao setor privado: caso de um balneário brasileiro. In: ANUATTI NETO, F.; MELLO, M. F. (Orgs). Regulação da infraestrutura no Brasil: casos didáticos, São Paulo: Editora Singular, 2008.

MENDONÇA, M. e MOTTA, R. "Saúde e Saneamento no Brasil", Texto para Discussão, IPEA, n. 1081, Brasília, 2005.

MOREIRA, T. A hora e a vez do saneamento. Revista do BNDES, Rio de Janeiro, n. 10, dez. 1998, p. 12.

MOREIRA, T. Saneamento básico: desafios e oportunidades. Revista do BNDES, Rio de Janeiro, n. 10, dez. 1996, p. 12. 
MPO/Sepurb/IPEA. Saneamento Modernização e Parceria com o setor privado. Série Modernização do Setor Saneamento, Brasília, n. 9, Disponível em: <http://www.pmss. gov.br/pmss/PaginaCarrega.php?EWRErterterTERTer=47> Acesso em: 22 mar. 2008.

NERI, M. C. Saneamento, Educação, Trabalho e Turismo, Instituto Trata Brasil e Fundação Getúlio Vargas, Centro de Políticas Socias, Rio de Janeiro, 2008. Disponível em: $<$ http://www3.fgv.br/ibrecps/Trata_regional/SC/Trata_CPSFGV_ITB_SantaCatarina.pdf $>$. Acesso em 10 jan. 2009.

OHIRA, T. H.; SHIROTA, R. Eficiência Econômica: uma aplicação do modelo de fronteira estocástica em empresas de saneamento. XXXIII Encontro Nacional de Economia, ANPEC, 2005.

OHIRA, T. H. Fronteira de eficiência em serviços de saneamento no Estado de São Paulo. 2005. 124p. Dissertação (Mestrado) - Escola Superior de Agricultura "Luiz de Queiroz", Universidade de São Paulo, Piracicaba, 2005.

OHIRA, T. H.; TUROLLA, F. A. Gestão, economia e regulação do setor de saneamento básico. In: XLIII CONGRESSO DA SOBER, 2005, Ribeirão Preto, Anais Instituições, Eficiência, Gestão e Contratos no Sistema Agroindustrial, Pôster, Disponível em: < http://www.sober.org.br/palestra/2/667.pdf >. Acesso em: 16 out 2008.

OHIRA, T.; SCAZUFCA, P. Métodos de análise de eficiência de empresas para o setor de saneamento. In: GESNER, O.; SCAZUFCA, P. (Orgs). A economia do saneamento no Brasil, São Paulo: Editora Singular, 2009.

PAREDES, R. Redistributive Impact of Privatization and the Regulation of Utilities in Chile United Nations University: WIDER. Discussion Paper, no. 2001/19.

PARLATORE, A. C. Privatização do setor de saneamento do Brasil. In: BNDES. A privatização no Brasil: o caso das utilidades públicas. Rio de Janeiro, 2000.

PINDYCK, R. S.; RUBINFELD, D. L. Microeconomia. São Paulo: Pearson Prentice Hall, 6. ed, 2005.

PIRES, J. C. L.; PICCININI, M. S. A economia brasileira nos anos 90: a regulação dos setores de infra-estrutura no Brasil. Disponível em $<$ http://www.bndes.gov. br/SiteBNDES/bndes/bndes_pt/Institucional/Publicacoes/Consulta_Expressa/Tipo/Livro/1999 10_25.html >. Acesso em: 10 out. 2009. 
PNAD. Pesquisa Nacional de Amostras e Domicílios 2007. Brasília, IBGE, 2007.

PNUD. Programa das Nações Unidas para o Desenvolvimento Nações Unidas para o Desenvolvimento. Os Objetivos do Milênio. Disponível em <www.pnud.org.br>. Acesso em 09 jan. 2009.

SAES, et all. Serviços Públicos no Brasil: mudanças e perspectivas. Concessão, regulamentação e melhoria da gestão pública. Editora Edgar Blücher Ltda, São Paulo, 1996.

SALGADO, L. H.; SEROA DA MOTTA, R. (Eds.). Marcos Regulatórios no Brasil: o que foi feito e o que falta fazer. Rio de Janeiro: Ipea, 2005.

SAMPAIO, B.; SAMPAIO, Y. Influências políticas na eficiência de empresas de saneamento brasileiras. Economia Aplicada, v. 11, n. 3, p. 369-386, jul-set. 2007.

SEROA DA MOTTA, R.; MOREIRA, A. Efficiency and regulation in the sanitation sector in Brazil. Brasília: IPEA, p. 185-195, dez. 2004. (Texto para Discussão, n. 1059).

SEROA DA MOTTA, R. As opções de marco regulatório de Saneamento no Brasil. Plenarium, Brasília, n.3, p. 100-116, set. 2006.

SEROA MOTTA, R. da, Critérios de alocação de recursos no setor de saneamento no Brasil. In: GESNER, O.; SCAZUFCA, P. (Orgs). A economia do saneamento no Brasil, São Paulo: Editora Singular, 2009.

SNIS. Sistema Nacional de Informação de Saneamento. Diagnósticos dos Serviços de Água e Esgoto 2000, 2001, 2002, 2003, 2004, 2005, 2006 e 2007. Brasília, Ministério das Cidades, 2000, 2001, 2002, 2003, 2004, 2005, 2006 e 2007.

STRINGHINI, A. C.; MARCATO, F. S. A gestão compartilhada dos serviços de saneamento básico: uma proposta para solução da polêmica da titularidade em regiões metropolitanas. In: GESNER, O.; SCAZUFCA, P. (Orgs). A economia do saneamento no Brasil, São Paulo: Editora Singular, 2009.

TONETO JÚNIOR, R. A situação atual do saneamento básico no Brasil: problemas e perspectivas. 2004. 323f. Teses de Livre Docência em Economia - Faculdade de Economia, Administração e Contabilidade de Ribeirão Preto, Universidade de São Paulo, Ribeirão Preto. 
TONETO, R. J.; SAIANI, C. C. S. Restrições à expansão dos investimentos no saneamento básico brasileiro. Revista Econômica do Nordeste, Fortaleza, v. 37, n. 4, p. 572-591, outdez. 2006.

TUPPER, H. C.; RESENDE, M. Efficiency and regulatory issues in the Brazilian water and sewage sector: an empirical study. Utilities Policy, n. 12, p. 29-40, 2004.

TUROLlA, F. A. Política de saneamento básico: avanços recentes e opções futuras de políticas públicas. Brasília: IPEA, p. 17-21, dez. 2002. (Texto para Discussão, n. 922).

TUROLLA, F. A.; OHIRA, T. H. Pontos para uma discussão sobre eficiência e regulação em saneamento. In: SALGADO, L. H.; SEROA DA MOTTA, R. Regulação e Concorrência no Brasil: governança, incentivos e eficiência. IPEA, 2007.

TUROLLA, F. A.; OHIRA, T. H.; LIMA, M. F. F. Aspectos econômicos da normatização dos serviços de água e esgoto. In: GALVÃO JR., A. C.; XIMENES, M. M. A. F. (org). Regulação - normatização da prestação de serviços de água e esgoto. ABAR e ARCE. 1. ed. Fortaleza: Pouchain Ramos, 2008.

TUROLla, F. A.; PAGANINI, W. S.; GALVÃO, A. C. J. Viabilidade da regulação subnacional dos serviços de abastecimento de água e esgotamento sanitário sob a lei 11.445/2007, Artigo Técnico Eng. Sanit. Ambient., v.13, n.2, abr/jun 2008, p. 134-143.

VALOR ECONÔMICO, Valor Setorial Saneamento, Rede para o Desenvolvimento, São Paulo: dez. 2008.

WATKINS. K. et al. Relatório do Desenvolvimento Humano 2006. New York. PNUD: 2006. 39 p. Disponível em: < http://www.pnud.org.br/rdh > Acesso em: 09 nov 2008.

WOOLDRIDGE, J. M. Econometric Analysis of Cross-Section and Panel Data. Cambridge: The MIT Press, 2001.

WOOLDRIDGE, J. M. Introdução à econometria: uma abordagem moderna. São Paulo: Pioneira Thomson Learning, 2006.

VARIAN, H. R. Microeconomia: princípios básicos. Rio de Janeiro: Campus, 1994. 


\section{APÊNDICE}

Tabela 1.1 - Mudanças de Natureza Jurídica dos prestadores de serviços de saneamento (1998-2004)

\begin{tabular}{|c|c|c|c|c|c|}
\hline Município & Estado & Região & $\begin{array}{l}\text { Ano da } \\
\text { Mudança }\end{array}$ & De (Ano Anterior) & Para (Ano da Mudança) \\
\hline Cachoeiro de Itapemirim & ES & SUDESTE & 1998 & AUTARQUIA & EMPRESA PRIVADA \\
\hline Petrópolis & RJ & SUDESTE & 1998 & EMPRESA PÚBLICA & EMPRESA PRIVADA \\
\hline Jaú & SP & SUDESTE & 1998 & ADMINISTRAÇÃO PÚBLICA DIRETA & AUTARQUIA \\
\hline Colatina & ES & SUDESTE & 1999 & AUTARQUIA & EMPRESA PÚBLICA \\
\hline Curitiba & PR & SUL & 1999 & SOCIEDADE ECO MISTA ADM. PÚB. & SOCIEDADE ECO MISTA ADM. PRI. \\
\hline Uberaba & MG & SUDESTE & 1999 & SOCIEDADE ECO MISTA ADM. PÚB. & AUTARQUIA \\
\hline Anta Gorda & RS & SUL & 2000 & AUTARQUIA & ADMINISTRAÇÃO PÚBLICA DIRETA \\
\hline Barra do Piraí & $\mathrm{RJ}$ & SUDESTE & 2000 & AUTARQUIA & ADMINISTRAÇÃO PÚBLICA DIRETA \\
\hline Colatina & ES & SUDESTE & 2000 & EMPRESA PÚBLICA & SOCIEDADE ECO MISTA ADM. PÚB. \\
\hline Guará & SP & SUDESTE & 2000 & ADMINISTRAÇÃO PÚBLICA DIRETA & EMPRESA PRIVADA \\
\hline Itambé & $\mathrm{PE}$ & NORDESTE & 2000 & AUTARQUIA & ADMINISTRAÇÃO PÚBLICA DIRETA \\
\hline Juiz de Fora & MG & SUDESTE & 2000 & EMPRESA PÚBLICA & SOCIEDADE ECO MISTA ADM. PÚB. \\
\hline Jundiaí & SP & SUDESTE & 2000 & AUTARQUIA & SOCIEDADE ECO MISTA ADM. PÚB. \\
\hline Resende & RJ & SUDESTE & 2000 & EMPRESA PÚBLICA & SOCIEDADE ECO MISTA ADM. PÚB. \\
\hline Uberaba & MG & SUDESTE & 2000 & AUTARQUIA & SOCIEDADE ECO MISTA ADM. PÚB. \\
\hline Santa Isabel & SP & SUDESTE & 2001 & EMPRESA PRIVADA & ADMINISTRAÇÃO PÚBLICA DIRETA \\
\hline Cuiabá & MT & CENTRO OESTE & 2001 & ADMINISTRAÇÃO PÚBLICA DIRETA & SOCIEDADE ECO MISTA ADM. PÚB. \\
\hline Juiz de Fora & MG & SUDESTE & 2001 & SOCIEDADE ECO MISTA ADM. PÚB. & EMPRESA PÚBLICA \\
\hline Palmas & TO & NORTE & 2001 & SOCIEDADE ECO MISTA ADM. PÚB. & SOCIEDADE ECO MISTA ADM. PRI. \\
\hline Uberaba & MG & SUDESTE & 2001 & SOCIEDADE ECO MISTA ADM. PÚB. & AUTARQUIA \\
\hline Artur Nogueira & SP & SUDESTE & 2002 & ADMINISTRAÇÃO PÚBLICA DIRETA & AUTARQUIA \\
\hline Campo Verde & MT & CENTRO OESTE & 2002 & AUTARQUIA & EMPRESA PRIVADA \\
\hline Colatina & ES & SUDESTE & 2002 & SOCIEDADE ECO MISTA ADM. PÚB. & EMPRESA PÚBLICA \\
\hline Dracena & SP & SUDESTE & 2002 & AUTARQUIA & EMPRESA PÚBLICA \\
\hline Itapiranga & $\mathrm{SC}$ & SUL & 2002 & AUTARQUIA & ADMINISTRAÇÃO PÚBLICA DIRETA \\
\hline Juína & MT & CENTRO OESTE & 2002 & ADMINISTRAÇÃO PÚBLICA DIRETA & AUTARQUIA \\
\hline Nova Mutum & MT & CENTRO OESTE & 2002 & ADMINISTRAÇÃO PÚBLICA DIRETA & AUTARQUIA \\
\hline Nova Xavantina & MT & CENTRO OESTE & 2002 & ADMINISTRAÇÃO PÚBLICA DIRETA & EMPRESA PRIVADA \\
\hline Rosário Oeste & MT & CENTRO OESTE & 2002 & ADMINISTRAÇÃO PÚBLICA DIRETA & AUTARQUIA \\
\hline São José do Rio Preto & SP & SUDESTE & 2002 & ADMINISTRAÇÃO PÚBLICA DIRETA & AUTARQUIA \\
\hline Senador Canedo & GO & CENTRO OESTE & 2002 & ADMINISTRAÇÃO PÚBLICA DIRETA & AUTARQUIA \\
\hline Novo Hamburgo & RS & SUL & 2003 & SOCIEDADE ECO MISTA ADM. PÚB. & ADMINISTRAÇÃO PÚBLICA DIRETA \\
\hline Almeirim & PA & NORTE & 2004 & ADMINISTRAÇÃO PÚBLICA DIRETA (2002) & AUTARQUIA \\
\hline Bacabal & MA & NORDESTE & 2004 & AUTARQUIA & ADMINISTRAÇÃO PÚBLICA DIRETA \\
\hline Campo Verde & MT & CENTRO OESTE & 2004 & AUTARQUIA (2000) & EMPRESA PRIVADA \\
\hline Caririaçu & $\mathrm{CE}$ & NORDESTE & 2004 & ADMINISTRAÇÃO PÚBLICA DIRETA & AUTARQUIA \\
\hline Carlinda & MT & CENTRO OESTE & 2004 & ADMINISTRAÇÃO PÚBLICA DIRETA & EMPRESA PRIVADA \\
\hline Cláudia & MT & CENTRO OESTE & 2004 & ADMINISTRAÇÃO PÚBLICA DIRETA & EMPRESA PRIVADA \\
\hline Doutor Ulysses & PR & SUL & 2004 & AUTARQUIA & ADMINISTRAÇÃO PÚBLICA DIRETA \\
\hline Iguaraçu & PR & SUL & 2004 & AUTARQUIA & ADMINISTRAÇÃO PÚBLICA DIRETA \\
\hline Juruena & MT & CENTRO OESTE & 2004 & ADMINISTRAÇÃO PÚBLICA DIRETA & EMPRESA PRIVADA \\
\hline Nova Guarita & MT & CENTRO OESTE & 2004 & ADMINISTRAÇÃO PÚBLICA DIRETA & AUTARQUIA \\
\hline
\end{tabular}

Fonte: Elaboração própria da autora baseada em SNIS (1995-2007). 
Tabela 1.2 - Mudanças de Natureza Jurídica dos prestadores de serviços de saneamento (2004-07)

\begin{tabular}{|c|c|c|c|c|c|}
\hline Município & Estado & Região & $\begin{array}{l}\text { Ano da } \\
\text { Mudança }\end{array}$ & De (Ano Anterior) & Para (Ano da Mudança) \\
\hline Palmas & TO & NORTE & 2004 & SOCIEDADE ECO MISTA ADM. PRI. & EMPRESA PRIVADA \\
\hline Pedra Preta & MT & CENTRO OESTE & 2004 & ADMINISTRAÇÃO PÚBLICA DIRETA & EMPRESA PRIVADA \\
\hline Resende & RJ & SUDESTE & 2004 & SOCIEDADE ECO MISTA ADM. PÚB. & AUTARQUIA \\
\hline Vera & MT & CENTRO OESTE & 2004 & ADMINISTRAÇÃO PÚBLICA DIRETA & EMPRESA PRIVADA \\
\hline Aripuanã & MT & CENTRO OESTE & 2005 & ADMINISTRAÇÃO PÚBLICA DIRETA & EMPRESA PÚBLICA \\
\hline Barra do Garças & MT & CENTRO OESTE & 2005 & ADMINISTRAÇÃO PÚBLICA DIRETA & EMPRESA PRIVADA \\
\hline Bacabal & MA & NORDESTE & 2005 & ADMINISTRAÇÃO PÚBLICA DIRETA & AUTARQUIA \\
\hline Catanduva & SP & SUDESTE & 2005 & ADMINISTRAÇÃO PÚBLICA DIRETA & EMPRESA PÚBLICA \\
\hline Catas Altas da Noruega & MG & SUDESTE & 2005 & EMPRESA PRIVADA & ADMINISTRAÇÃO PÚBLICA DIRETA \\
\hline Colatina & ES & SUDESTE & 2005 & EMPRESA PÚBLICA & AUTARQUIA \\
\hline Corumbiara & RO & NORTE & 2005 & ADMINISTRAÇÃO PÚBLICA DIRETA & EMPRESA PÚBLICA \\
\hline Crato & $\mathrm{CE}$ & NORDESTE & 2005 & SOCIEDADE ECO MISTA ADM. PRI. & SOCIEDADE ECO MIST A ADM. PÚB. \\
\hline Darcinópolis & TO & NORTE & 2005 & ADMINISTRAÇÃO PÚBLICA DIRETA & SOCIEDADE ECO MISTA ADM. PÚB. \\
\hline Doutor Ulysses & PR & SUL & 2005 & ADMINISTRAÇÃO PÚBLICA DIRETA & AUTARQUIA \\
\hline Jangada & MT & CENTRO OESTE & 2005 & ADMINISTRAÇÃO PÚBLICA DIRETA & EMPRESA PRIVADA \\
\hline Lambari D'Oeste & MT & CENTRO OESTE & 2005 & ADMINISTRAÇÃO PÚBLICA DIRETA & EMPRESA PRIVADA \\
\hline Manicoré & $\mathrm{AM}$ & NORTE & 2005 & EMPRESA PRIVADA & ADMINISTRAÇÃO PÚBLICA DIRETA \\
\hline Mirassol d'Oeste & MT & CENTRO OESTE & 2005 & EMPRESA PRIVADA & AUTARQUIA \\
\hline Novo Hamburgo & RS & SUL & 2005 & ADMINISTRAÇÃO PÚBLICA DIRETA & SOCIEDADE ECO MISTA ADM. PÚB. \\
\hline Nova Brasilândia & MT & CENTRO OESTE & 2005 & ADMINISTRAÇÃO PÚBLICA DIRETA & AUTARQUIA \\
\hline Ouro Preto & MG & SUDESTE & 2005 & ADMINISTRAÇÃO PÚBLICA DIRETA & AUTARQUIA \\
\hline Parauapebas & PA & NORTE & 2005 & EMPRESA PRIVADA & AUTARQUIA \\
\hline Porto Esperidião & MT & CENTRO OESTE & 2005 & ADMINISTRAÇÃO PÚBLICA DIRETA & EMPRESA PRIVADA \\
\hline Rancharia & SP & SUDESTE & 2005 & ADMINISTRAÇÃO PÚBLICA DIRETA & EMPRESA PÚBLICA \\
\hline Raposa & MA & NORDESTE & 2005 & ADMINISTRAÇÃO PÚBLICA DIRETA & AUTARQUIA \\
\hline Rosário & MA & NORDESTE & 2005 & ADMINISTRAÇÃO PÚBLICA DIRETA & AUTARQUIA \\
\hline São Sebastião do Uatumã & $\mathrm{AM}$ & NORTE & 2005 & ADMINISTRAÇÃO PÚBLICA DIRETA & AUTARQUIA \\
\hline Sapezal & MT & CENTRO OESTE & 2005 & ADMINISTRAÇÃO PÚBLICA DIRETA & EMPRESA PRIVADA \\
\hline Talismã & TO & NORTE & 2005 & ADMINISTRAÇÃO PÚBLICA DIRETA & EMPRESA PRIVADA \\
\hline Tangará da Serra & MT & CENTRO OESTE & 2005 & ADMINISTRAÇÃO PÚBLICA DIRETA & AUTARQUIA \\
\hline Tapurah & MT & CENTRO OESTE & 2005 & AUTARQUIA & ADMINISTRAÇÃO PÚBLICA DIRETA \\
\hline Torixoréu & MT & CENTRO OESTE & 2005 & ADMINISTRAÇÃO PÚBLICA DIRETA & EMPRESA PÚBLICA \\
\hline Três Pontas & MG & SUDESTE & 2005 & ADMINISTRAÇÃO PÚBLICA DIRETA & AUTARQUIA \\
\hline Vinhedo & SP & SUDESTE & 2005 & ADMINISTRAÇÃO PÚBLICA DIRETA & AUTARQUIA \\
\hline Votorantim & SP & SUDESTE & 2005 & ADMINISTRAÇÃO PÚBLICA DIRETA & AUTARQUIA \\
\hline Buritis & RO & NORTE & 2006 & EMPRESA PRIVADA & ADMINISTRAÇÃO PÚBLICA DIRETA \\
\hline Cáceres & MT & CENTRO OESTE & 2006 & EMPRESA PRIVADA & ADMINISTRAÇÃO PÚBLICA DIRETA \\
\hline Catanduva & SP & SUDESTE & 2006 & EMPRESA PÚBLICA & ADMINISTRAÇÃO PÚBLICA DIRETA \\
\hline Cocal de Telha & PI & NORDESTE & 2006 & ADMINISTRAÇÃO PÚBLICA DIRETA & AUTARQUIA \\
\hline Diamantino & MT & CENTRO OESTE & 2006 & EMPRESA PRIVADA & ADMINISTRAÇÃO PÚBLICA DIRETA \\
\hline Lambari D'Oeste & MT & CENTRO OESTE & 2006 & EMPRESA PRIVADA & ADMINISTRAÇÃO PÚBLICA DIRETA \\
\hline Juruena & MT & CENTRO OESTE & 2006 & EMPRESA PRIVADA & EMPRESA PÚBLICA \\
\hline Ipanema & MG & SUDESTE & 2006 & ADMINISTRAÇÃO PÚBLICA DIRETA & AUTARQUIA \\
\hline Itacurubi & $\mathrm{RS}$ & SUL & 2006 & ADMINISTRAÇÃO PÚBLICA DIRETA & AUTARQUIA \\
\hline Itajobi & SP & SUDESTE & 2006 & AUTARQUIA & ADMINISTRAÇÃO PÚBLICA DIRETA \\
\hline Melgaço & PA & NORTE & 2006 & AUTARQUIA & ADMINISTRAÇÃO PÚBLICA DIRETA \\
\hline Parauapebas & $\mathrm{PA}$ & NORTE & 2006 & AUTARQUIA & ADMINISTRAÇÃO PÚBLICA DIRETA \\
\hline Porto de Moz & PA & NORTE & 2006 & AUTARQUIA & ADMINISTRAÇÃO PÚBLICA DIRETA \\
\hline Santa Carmem & MT & CENTRO OESTE & 2006 & ADMINISTRAÇÃO PÚBLICA DIRETA & EMPRESA PRIVADA \\
\hline Sarandi & PR & SUL & 2006 & ADMINISTRAÇÃO PÚBLICA DIRETA & AUTARQUIA \\
\hline Sinop & MT & CENTRO OESTE & 2006 & ADMINISTRAÇÃO PÚBLICA DIRETA & AUTARQUIA \\
\hline Torixoréu & MT & CENTRO OESTE & 2006 & ADMINISTRAÇÃO PÚBLICA DIRETA (2001) & EMPRESA PÚBLICA \\
\hline Tucuruí & PA & NORTE & 2006 & ADMINISTRAÇÃO PÚBLICA DIRETA & AUTARQUIA \\
\hline Amaraji & $\mathrm{PE}$ & NORDESTE & 2007 & AUTARQUIA (2005) & ADMINISTRAÇÃO PÚBLICA DIRETA \\
\hline Granja & $\mathrm{CE}$ & NORDESTE & 2007 & AUTARQUIA (2005) & ADMINISTRAÇÃO PÚBLICA DIRETA \\
\hline
\end{tabular}

Fonte: Elaboração própria da autora baseada em SNIS (1995-2007). 
Quadro 1.1

Declaração do Milênio: objetivos e metas

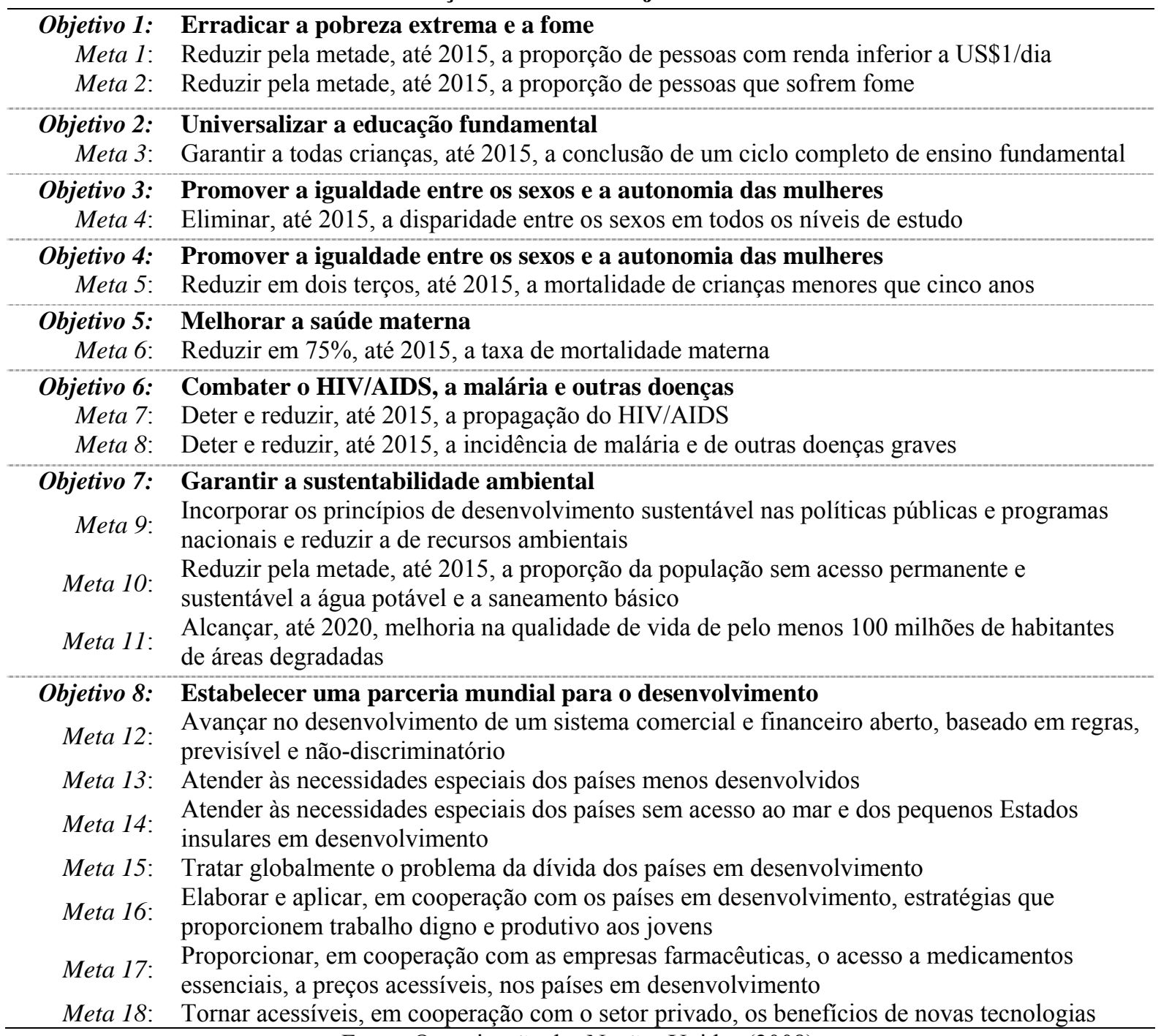
Fonte: Organização das Nações Unidas (2008).

\section{- Descrição do cálculo dos indicadores utilizados nas estimações:}

1) Tarifa média praticada $\left(\mathbf{R} \$ / \mathbf{m}^{3}\right)$ : Indicador referente à receita operacional direta de água e esgoto pelo volume total faturado de água e esgoto. A receita operacional direta é composta pelo valor faturado anual decorrente da prestação do serviço de abastecimento de água e esgotamento sanitário, incluído os valores decorrentes da venda de água exportada no atacado (bruta ou tratada) e os valores decorrentes da importação de esgotos. O volume total faturado de água e esgoto corresponde ao volume anual de água e esgoto debitado ao total de economias (medidas e não medidas), ao volume de água tratada exportado e ao volume decorrente da importação de esgotos, para fins de faturamento. 
2) Despesa total com os serviços por $\mathbf{m}^{3}$ faturado $\left(\mathbf{R} \$ / \mathbf{m}^{3}\right)$ : Variável referente às despesas totais com os serviços pelo volume total faturado de água e esgoto. As despesas totais com os serviços (DTS) referem-se ao conjunto das despesas realizadas para a prestação dos serviços, compreendendo despesas de exploração (DEX), despesas com juros e encargos das dívidas (incluindo as despesas decorrentes de variações monetárias e cambiais), despesas com depreciação, amortização do ativo diferido e provisão para devedores duvidosos, despesas fiscais ou tributárias não Computadas na DEX, mas que compõem a DTS, além de outras despesas com os serviços. O volume total faturado de água e esgoto corresponde ao volume anual de água e esgoto debitado ao total de economias (medidas e não medidas), ao volume de água tratada exportado e ao volume decorrente da importação de esgotos, para fins de faturamento.

3) Empregados próprios por mil ligações de água e esgoto (empregados/mil ligações): Quantidade total de empregados próprios por quantidade total de ligações ativas de água e esgoto. A quantidade total de empregados próprios refere-se a funcionários do prestador de serviços, dirigentes ou outros, postos permanentemente e com ônus- à disposição do prestador de serviços, ao final do ano de referência. A quantidade total de ligações ativas de água e esgoto é a quantidade de ligações ativas de água à rede pública, providas ou não de hidrômetro, que contribuíram para o faturamento, no último dia do ano de referência.

4) Densidade de economias de água por ligação (economia/ligação): Quantidade de economias de água ativas que contribuíram para o faturamento, no último dia do ano de referência, por quantidade de ligações ativas de água à rede pública, providas ou não de hidrômetro, que contribuíram para o faturamento, no último dia do ano de referência.

5) Índice de desempenho financeiro (\%): Receita operacional direta, valor faturado anual decorrente da prestação do serviço de abastecimento de água e esgotamento sanitário, incluído os valores decorrentes da venda de água exportada no atacado (bruta ou tratada) e os valores decorrentes da importação de esgotos; por despesas totais com os serviços (DTS), valor anual total do conjunto das despesas realizadas para a prestação dos serviços, compreendendo despesas de exploração (DEX), despesas com juros e encargos das dívidas (incluindo as despesas decorrentes de variações monetárias e cambiais), despesas com depreciação, amortização do ativo 
diferido e provisão para devedores duvidosos, despesas fiscais ou tributárias não computadas na DEX, mas que compõem a DTS, além de outras despesas com os serviços.

6) Índice de atendimento total de água: Relação entre a população total atendida com abastecimento de água e a população total do(s) município(s) atendidos com abastecimento de água. A população total atendida com abastecimento de água referese ao valor da soma das populações urbana e rural -sedes municipais e localidadesatendidas com abastecimento de água pelo prestador de serviços, no último dia do ano de referência. Corresponde à população que é efetivamente servida com os serviços, ou seja, está associada à quantidade de economias residenciais ativas de água. No SNIS é adotado o valor estimado pelo próprio prestador de serviços, que em geral faz uma estimativa usando o produto da quantidade de economias residenciais ativas de água na zona rural e urbana ${ }^{43}$ multiplicada pela taxa média de habitantes por domicílio do respectivo município, obtida no último Censo ou Contagem de População do IBGE. Não deve ser confundida com a população total dos municípios atendidos com abastecimento de água. A população total do(s) município(s) atendidos com abastecimento de água é igual ao valor da soma das populações urbanas e rurais dos municípios -sedes municipais e localidades- em que o prestador de serviços atua com serviços de abastecimento de água (aplica-se aos dados agregados da amostra de prestadores de serviços). Inclui tanto a população servida quanto a que não é servida com os serviços. Para cada município é adotada no SNIS a estimativa realizada anualmente pelo IBGE, ou as populações obtidas por meio de Censos demográficos ou Contagens populacionais também do IBGE.

7) Índice de perdas na distribuição (\%): Corresponde ao volume de água (que inclui o volume produzido, tratado importado menos o de serviço) deduzido do volume de água consumido pelo volume de água (que inclui o volume produzido, tratado importado menos o de serviço). O volume produzido é igual ao volume de água captado pelo prestador de serviços mais a água importada bruta, ambas tratadas na(s) unidade(s) de tratamento do prestador de serviços, medido ou estimado na(s) saída(s) da(s) Estação(ões) de Tratamento de Água - ETA(s) ou Unidade(s) de Tratamento Simplificado (UTS). Inclui também volumes de água captada pelo prestador de serviços que sejam distribuídos sem tratamento. Trata-se de volumes produzidos

${ }^{43}$ O cálculo é feito separadamente para a zona rural e depois para a zona urbana. A quantidade de economias residenciais ativas de água é obtida somando-se essas duas parcelas. 
dentro dos limites do município em questão. Este volume pode ter parte dele exportada para outro(s) município(s). O volume de água tratada importado corresponde ao volume de água potável, previamente tratada (em ETA ou por simples desinfecção), recebido de outro(s) município(s), independentemente se do mesmo prestador de serviços ou não. O volume de água de serviço diz respeito ao valor da soma dos volumes anuais de água usados para atividades operacionais e especiais com o volume de água recuperado. Por fim, o volume de água consumido é igual ao volume anual de água consumido por todos os usuários, compreendendo o volume micromedido (volume anual de água medido pelos hidrômetros instalados nos ramais prediais), o volume de consumo estimado para as ligações desprovidas de hidrômetro ou com hidrômetro parado e o volume de água tratada exportado. Não deve ser confundido com o volume de água faturada, pois para o cálculo desse último, os prestadores de serviços adotam parâmetros de consumo mínimo ou médio, que podem ser superiores aos volumes efetivamente consumidos.

8) Índice de perdas no faturamento (\%): Corresponde ao volume de água (que inclui o volume produzido, tratado importado menos o de serviço) deduzido do volume de água faturado pelo volume de água (que inclui o volume produzido, tratado importado menos o de serviço). O volume produzido é igual ao volume de água captado pelo prestador de serviços mais a água importada bruta, ambas tratadas na(s) unidade(s) de tratamento do prestador de serviços, medido ou estimado na(s) saída(s) da(s) Estação(ões) de Tratamento de Água - ETA(s) ou Unidade(s) de Tratamento Simplificado (UTS). Inclui também volumes de água captada pelo prestador de serviços que sejam distribuídos sem tratamento. Trata-se de volumes produzidos dentro dos limites do município em questão. Este volume pode ter parte dele exportada para outro(s) município(s). O volume de água tratada importado corresponde ao volume de água potável, previamente tratada (em ETA ou por simples desinfecção), recebido de outro(s) município(s), independentemente se do mesmo prestador de serviços ou não. O volume de água de serviço diz respeito ao valor da soma dos volumes anuais de água usados para atividades operacionais e especiais com o volume de água recuperado. O volume de água faturado refere-se ao volume anual de água debitado ao total de economias (medidas e não medidas), para fins de faturamento. Inclui o volume de água tratada exportado. 


\section{9) Índice de atendimento total de esgoto referido aos municípios atendidos com} água (\%): Relação entre a população total atendida com esgotamento sanitário e a população total do(s) município(s) atendidos com abastecimento de água. A população total atendida com esgotamento sanitário é igual ao valor da soma das populações urbana e rural -sedes municipais e localidades- atendidas com esgotamento sanitário pelo prestador de serviços, no último dia do ano de referência. Corresponde à população que é efetivamente servida com os serviços, ou seja, está associada à quantidade de economias residenciais ativas de esgoto na zona rural e urbana. No SNIS é adotado o valor estimado pelo próprio prestador de serviços, que em geral faz uma estimativa usando o produto da quantidade de economias residenciais ativas de esgoto na zona rural e urbana ${ }^{44}$ multiplicada pela taxa média de habitantes por domicílio do respectivo município, obtida no último Censo ou Contagem de População do IBGE. Não deve ser confundida com a população total dos municípios atendidos com esgotamento sanitário.

10) Índice de coleta de esgoto (\%): Volume esgoto coletado pela parcela referente ao volume de água consumido deduzido do volume de água tratado exportado. O volume de esgoto coletado é relativo ao volume anual de esgoto lançado na rede coletora. Em geral é considerado como sendo de $80 \%$ a $85 \%$ do volume de água consumido na mesma economia. Não inclui volume de esgoto bruto importado - volume de esgoto recebido de outro(s) agente(s). O volume de água consumido é igual ao volume anual de água consumido por todos os usuários, compreendendo o volume micromedido (volume anual de água medido pelos hidrômetros instalados nos ramais prediais), o volume de consumo estimado para as ligações desprovidas de hidrômetro ou com hidrômetro parado e o volume de água tratada exportado. Não deve ser confundido com o volume de água faturada, pois para o cálculo desse último, os prestadores de serviços adotam parâmetros de consumo mínimo ou médio, que podem ser superiores aos volumes efetivamente consumidos. Por último, o volume de água tratado exportado é igual ao volume de água potável, previamente tratada (em ETA ou por simples desinfecção), transferido do município onde está localizado o sistema produtor, para outro(s) município(s), independentemente se esses são atendidos pelo mesmo prestador de serviços.

\footnotetext{
${ }^{44} \mathrm{O}$ cálculo é feito separadamente para a zona rural e depois para a zona urbana. A quantidade de economias residenciais ativas de esgoto é obtida somando-se essas duas parcelas.
} 
11) Índice de Tratamento de Esgoto: Corresponde ao volume de esgoto tratado pela soma do volume de esgoto coletado com o volume de esgoto importado. O volume de esgoto tratado é composto do volume anual de esgoto submetido a tratamento, medido ou estimado na(s) entrada(s) da(s) ETE(s) - Estações de Tratamento de Esgoto mais o volume de esgoto bruto importado que foi tratado nas instalações do importador volume de esgoto recebido de outro(s) agente(s) submetido a tratamento, medido ou estimado na(s) entrada(s) da(s) ETE(s). O volume de esgoto coletado diz respeito ao volume anual de esgoto lançado na rede coletora, em geral é considerado como sendo de $80 \%$ a $85 \%$ do volume de água consumido na mesma economia, mais o volume de esgoto bruto importado, ou seja, volume de esgoto recebido de outro(s) agente(s).

12) Investimento total por ligações de água e esgoto $(\mathbf{R} \$ / \text { ligação) })^{45}$ : $\underline{\text { Investimentos }}$ totais pelo número de ligações totais de água e esgoto. Os investimentos totais realizados correspondem ao resultado da soma dos investimentos em abastecimento de água, em esgotamento sanitário e em outros investimentos, mais as despesas capitalizáveis; ou da soma dos investimentos com recursos próprios, com recursos onerosos e com recursos não onerosos, mais as despesas capitalizáveis. O valor do número de ligações totais de água e esgoto é igual a quantidade de ligações totais (ativas e inativas) de esgoto à rede pública, existentes no último dia do ano de referência, mais a quantidade de ligações totais (ativas e inativas) de água à rede pública, providas ou não de hidrômetro, existente no último dia do ano de referência.

13) Investimento total por habitante ( $R$ /habitante): Investimentos totais pela população total dos municípios. Os investimentos totais realizados correspondem ao resultado da soma dos investimentos em abastecimento de água, em esgotamento sanitário e em outros investimentos, mais as despesas capitalizáveis; ou da soma dos investimentos com recursos próprios, com recursos onerosos e com recursos não onerosos, mais as despesas capitalizáveis. A população total do município é o valor da soma das populações urbana e rural de um município -sede municipal e localidades(aplica-se à amostra de dados municipais). Inclui tanto a população servida quanto a que não é servida com os serviços. É adotada no SNIS a estimativa realizada anualmente pelo IBGE, ou os resultados oriundos de Censos demográficos ou Contagens populacionais, também do IBGE.

\footnotetext{
${ }^{45}$ O SNIS coleta informações sobre os investimentos segundo o destino dos recursos (investimento realizado em abastecimento de água, investimento realizado em esgotamento sanitário e outros investimentos) e também segundo a origem dos recursos (investimento com recursos próprios, onerosos e não onerosos).
} 
14) Investimentos realizados com recursos onerosos (R\$): Parcela dos investimentos totais realizados com recursos onerosos: investimento com recursos onerosos por investimentos totais. Os investimentos com recursos onerosos são aqueles referentes ao valor anual dos investimentos realizados com recursos de financiamentos, retornáveis por meio de amortizações, juros e outros encargos. Os investimentos totais realizados correspondem ao resultado da soma dos investimentos em abastecimento de água, em esgotamento sanitário e em outros investimentos, mais as despesas capitalizáveis; ou da soma dos investimentos com recursos próprios, com recursos onerosos e com recursos não onerosos, mais as despesas capitalizáveis.

15) Investimentos realizados com recursos não onerosos: Parcela dos investimentos totais realizados com recursos não onerosos: investimento com recursos não onerosos por investimentos totais. Os investimentos com recursos não onerosos refere-se ao valor anual dos investimentos realizados com recursos não reembolsáveis, que não oneram o serviço da dívida, também denominados recursos a fundo perdido. Os investimentos totais realizados correspondem ao resultado da soma dos investimentos em abastecimento de água, em esgotamento sanitário e em outros investimentos, mais as despesas capitalizáveis; ou da soma dos investimentos com recursos próprios, com recursos onerosos e com recursos não onerosos, mais as despesas capitalizáveis.

16) Índice de qualidade: A partir dos seguintes indicadores de qualidade: duração média dos serviços executados (horas/serviço), duração média das paralisações (horas/paralisação), incidência de análises de cloro residual fora do padrão (\%), incidência de análises de turbidez fora do padrão (\%), incidência de análises de coliformes fecais fora do padrão (\%), extravasamentos de esgoto por extensão de rede (extravasamento $/ \mathrm{km}$ ); utilizou-se uma fórmula para cada um deles que se refere ao valor do indicador menos o pior valor entre todos os valores da amostra pelo intervalo entre o melhor valor e o pior entre todos os valores da amostra ${ }^{46}$. Após a aplicação dessa fórmula para cada indicador, foi realizada a média de todos os indicadores para obter-se o valor do índice em questão ${ }^{47}$.

\footnotetext{
${ }^{46}$ Ou seja, foi calculado para cada município um indicador entre zero e um, pois se o valor individual para um determinado município for igual ao valor máximo dentre os valores de todos os municípios, irá obter-se um indicador igual a um. Contudo se esse valor individual for igual ao pior valor do intervalo, o indicador será igual a zero.

${ }^{47}$ Para todos os indicadores a seguir, no caso do município atendido por mais de um sistema, as durações das paralisações dos diversos sistemas devem ser somadas.
} 
17.1) Duração média das paralisações (horas/paralisação): Duração das paralisações por quantidade de paralisações. A duração das paralisações corresponde a quantidade de horas, no ano, em que ocorreram paralisações no sistema de distribuição de água. Devem ser somadas somente as durações de paralisações que, individualmente, foram iguais ou superiores a seis horas. A quantidade de paralisações no sistema de distribuição de água refere-se à quantidade de vezes, no ano, inclusive repetições, em que ocorreram paralisações no sistema de distribuição de água. Devem ser somadas somente as paralisações que, individualmente, tiveram duração igual ou superior a seis horas.

17.2) Duração média dos serviços executados (horas/serviço): Tempo de execução dos serviços por quantidade de serviços executados. Tempo total de execução dos serviços é igual a quantidade total anual de horas despendida no conjunto de ações para execução dos serviços, desde a primeira reclamação ou solicitação até a conclusão do serviço. A quantidade de serviços executados é relativa a quantidade total anual de serviços executados no(s) sistema(s) de abastecimento de água e de esgotamento sanitário relativa às reclamações ou solicitações feitas.

17.3) Incidência das análises de cloro residual fora do padrão (\%): Quantidade de amostras analisadas para aferição de cloro residual livre com resultados fora do padrão por quantidade de amostras analisadas para aferição de cloro residual livre. A quantidade de amostras analisadas para aferição de cloro residual livre com resultados fora do padrão é a quantidade total anual de amostras coletadas na(s) saída(s) da(s) unidade(s) de tratamento e no sistema de distribuição de água (reservatórios e redes), para aferição do teor de cloro residual livre na água, cujo resultado da análise ficou fora do padrão determinado pela Portaria 518/04 do Ministério da Saúde. A quantidade de amostras analisadas para aferição de cloro residual livre refere-se à quantidade total anual de amostras coletadas na(s) saída(s) da(s) unidade(s) de tratamento e no sistema de distribuição de água (reservatórios e redes), para aferição do teor de cloro residual livre na água.

17.4) Incidência das análises de turbidez fora do padrão (\%): Relação entre a quantidade de amostras analisadas para aferição de turbidez com resultados fora do padrão pela quantidade de amostras analisadas para aferição de turbidez. A quantidade de amostras analisadas para aferição de turbidez com resultados fora do padrão é igual a quantidade total anual de amostras coletadas na(s) saída(s) da(s) 
unidade(s) de tratamento e no sistema de distribuição de água (reservatórios e redes), para aferição do teor de turbidez da água, cujo resultado da análise ficou fora do padrão determinado pela Portaria 518/04 do Ministério da Saúde. A quantidade de amostras analisadas para aferição de turbidez corresponde à quantidade total anual de amostras coletadas na(s) saída(s) da(s) unidade(s) de tratamento e no sistema de distribuição de água (reservatórios e redes), para aferição do teor de turbidez da água.

17.5) Incidência das análises de coliformes totais fora do padrão (\%): Quantidade de amostras analisadas para aferição de coliformes totais com resultados fora do padrão pela quantidade de amostras analisadas para aferição de coliformes totais. A quantidade de amostras analisadas para aferição de coliformes totais com resultados fora do padrão é a quantidade total anual de amostras coletadas na(s) saída(s) da(s) unidade(s) de tratamento e na rede de distribuição de água, para aferição do teor de coliformes totais, cujo resultado da análise ficou fora do padrão determinado pela Portaria 518/04 do Ministério da Saúde. A quantidade de amostras analisadas para aferição de coliformes totais é relativa a quantidade total anual de amostras coletadas na(s) saída(s) da(s) unidade(s) de tratamento e no sistema de distribuição de água (reservatórios e redes), para aferição do teor de coliformes totais.

17.6) Extravasamentos de Esgotos por Extensão de Rede (extravasamento/km): Quantidade de extravasamentos de esgotos registrados é a quantidade de vezes, no ano, inclusive repetições, em que foram registrados extravasamentos na rede de coleta de esgotos. Extensão da rede de esgoto é igual ao comprimento total da malha de coleta de esgoto, incluindo redes de coleta, coletores e interceptores e excluindo ramais prediais e emissários de recalque, operada pelo prestador de serviços, no último dia do ano de referência.

- Descrição de outras variáveis explicativas utilizadas em algumas estimações:

1) Empresa local pública ("local_publica"): há quinhentos e trinta e dois (532) municípios que são atendidos por empresa de saneamento de abrangência local cuja natureza jurídica pode ser sociedade de economia mista com administração pública (10), empresa pública (9), autarquia (320) ou administração pública direta (193). 
2) Empresa local_privada ("local_privada"): na amostra do SNIS, para o ano de 2007, conforme tabela 4.5, existem trinta e nove (39) empresas prestadoras de serviços de saneamento básico, de abrangência local, atuantes cada uma em um município, de natureza jurídica empresa privada. Para o indicador de tratamento de esgoto foi necessário comparar, dentro do grupo das locais apenas ${ }^{48}$, a diferença das locais privadas com as locais públicas.

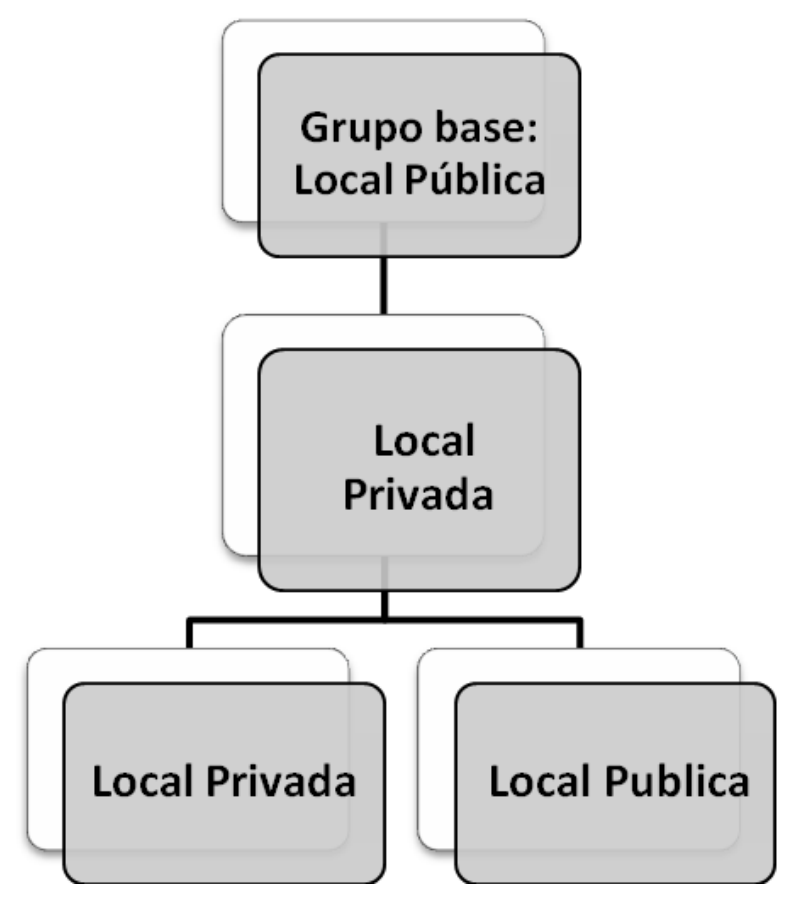

3) Empresa não local pública ("não_local_publica"): esse grupo é formado pelas empresas regionais e microrregionais (não local) classificadas como pública, ou seja, que podem pertencer à natureza jurídica sociedade de economia mista com administração pública (3.468), sociedade de economia mista com administração privada (345) ou autarquia (31), totalizando 3.844 municípios atendidos por esse tipo de empresa.

4) Empresa não local privada ("não_local_privada"): esse grupo é formado pelas empresas regionais ou microrregionais cuja natureza jurídica é empresa privada, ou seja, cento e vinte e um (121) municípios atendidos pela empresa privada regional SANEATINS e onze (11) municípios atendidos pelas empresas privadas microrregionais, CAJ, PROLAGOS e SETAE. Portanto, na amostra do SNIS, existe

\footnotetext{
${ }^{48}$ As empresas regionais foram retiradas da amostra pra ser feita essa comparação.
} 
um total de cento e trinta e dois municípios atendidos por empresas privadas não locais.

5) Empresa privada ("privada_total"): todas as empresas de saneamento que são classificadas pelo SNIS como empresa privada, independente da abrangência geográfica (regional, microrregional ou local) entraram nesse grupo. Portanto, compõe essa categoria os municípios servidos pelas trinta e nove empresas locais privadas, acima mencionadas, os cento e vinte e um municípios atendidos pela empresa privada regional SANEATINS e os onze municípios atendidos pelas empresas privadas microrregionais, CAJ, PROLAGOS e SETAE. Portanto, na amostra do SNIS, existe um total de cento e setenta e um municípios atendidos por empresas privadas. A importância dessa variável está na possibilidade de se medir o impacto do setor privado nos diversos indicadores selecionados e, conseqüentemente, mensurar a magnitude de suas esferas de atuação ${ }^{49}$. Ao estimar a regressão com essa variável juntamente com as variáveis de controle, o grupo base de comparação é o das empresas públicas em geral. Dessa forma, compara-se a empresa privada com todo o universo de empresas públicas da amostra, independente da abrangência geográfica.

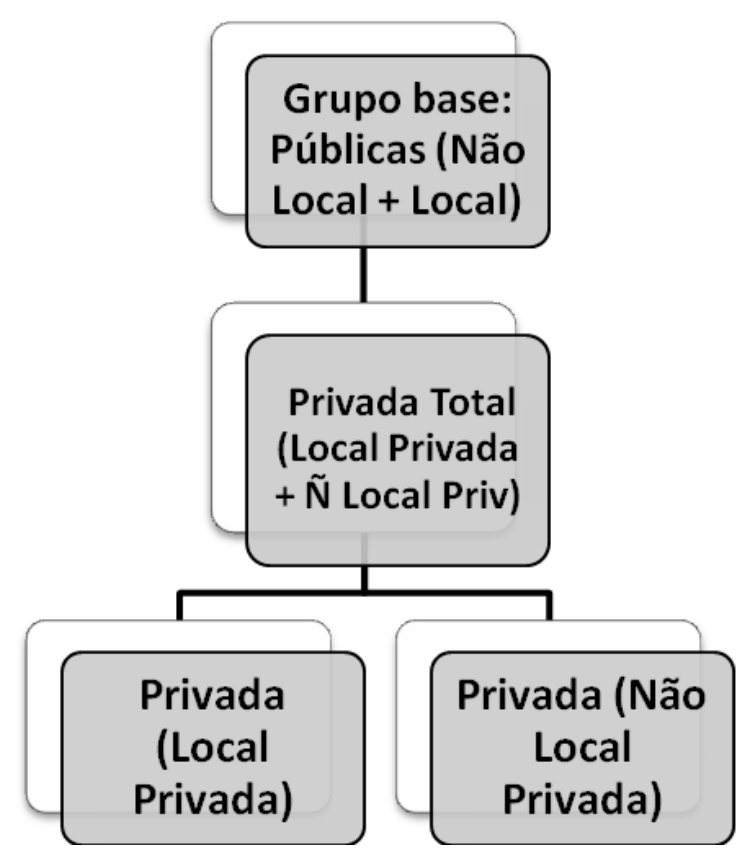

A SANEPAR, empresa regional cuja natureza jurídica é sociedade de economia mista com administração privada, apesar de possuir maior participação dos sócios privados na gestão dos negócios (o grupo Dominó comprou 39\% do capital da empresa), não foi incluída no grupo das privadas, pelo fato de possuir capital público. Dessa forma, pretende-se deixar livre o grupo das empresas privadas de qualquer tipo de capital público. 
6) Empresas locais ("local”): A intenção dessa última categoria foi agrupar as empresas de abrangência local (independente do tipo de natureza jurídica) para verificar se uma possível municipalização é superior a atuação agregada e centralizada das empresas regionais, como é visto atualmente. Essa variável é a soma das duas primeiras variáveis binárias: locai privadas e locais públicas. Portanto, totaliza-se uma quantidade de quinhentos e setenta e um municípios que são atendidos por empresas de abrangência local. A variável resultante da soma das duas empresas locais foi utilizada em apenas duas estimações para ressaltar a importância da empresa, cuja atuação está restrita aos limites municipais.

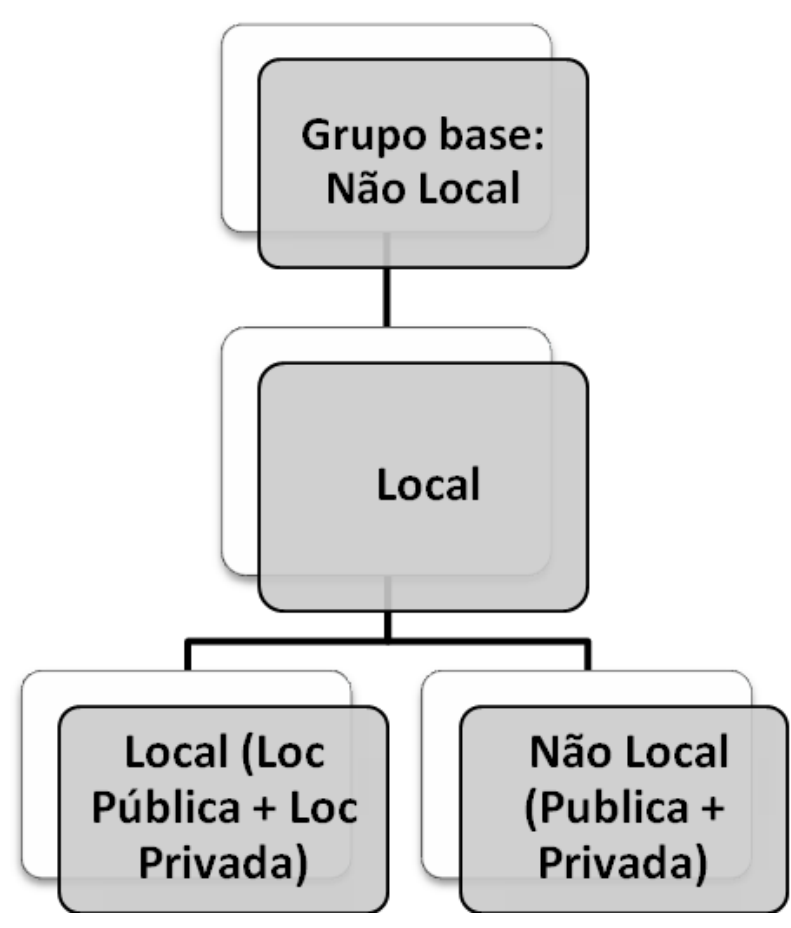

